Prepared in cooperation with the South Carolina Department of Transportation

\title{
The South Carolina Bridge-Scour Envelope Curves
}

Scientific Investigations Report 2016-5121 Version 1.2, April 2021 
Cover. Little Pee Dee River at S.C. 917 in Horry County, South Carolina, April 20, 2007. Photograph by U.S. Geological Survey. 


\section{The South Carolina Bridge-Scour Envelope Curves}

By Stephen T. Benedict, Toby D. Feaster, and Andral W. Caldwell

Prepared in cooperation with the South Carolina Department of Transportation

Scientific Investigations Report 2016-5121

Version 1.2, April 2021 


\title{
U.S. Department of the Interior \\ RYAN K. ZINKE, Secretary
}

\section{U.S. Geological Survey}

William H. Werkheiser, Deputy Director exercising the authority of the Director

\author{
U.S. Geological Survey, Reston, Virginia \\ First release: 2016 \\ Revised: January 2018 (ver. 1.1) \\ Revised: April 2021 (ver. 1.2)
}

For more information on the USGS —-the Federal source for science about the Earth, its natural and living resources, natural hazards, and the environment—visit http://www.usgs.gov or call 1-888-ASK-USGS.

For an overview of USGS information products, including maps, imagery, and publications,

visit http://store.usgs.gov.

Any use of trade, firm, or product names is for descriptive purposes only and does not imply endorsement by the U.S. Government.

Although this information product, for the most part, is in the public domain, it also may contain copyrighted materials as noted in the text. Permission to reproduce copyrighted items must be secured from the copyright owner.

Suggested citation:

Benedict, S.T., Feaster, T.D., and Caldwell, A.W., 2016, The South Carolina bridge-scour envelope curves (ver. 1.2, April 2021): U.S. Geological Survey Scientific Investigations Report 2016-5121, 96 p.,

https://doi.org/10.3133/sir20165121.

ISSN 2328-0328 (online) 


\section{Contents}

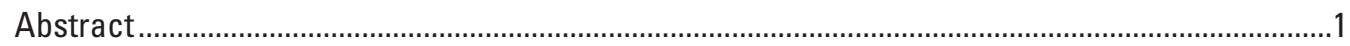

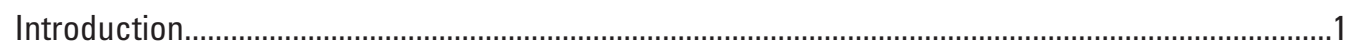

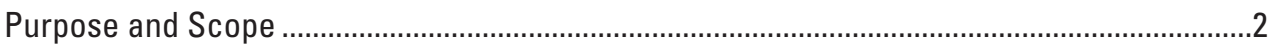

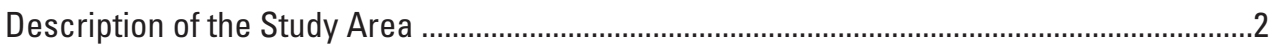

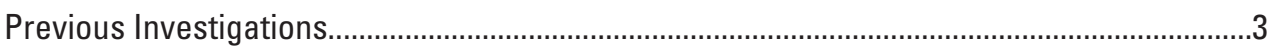

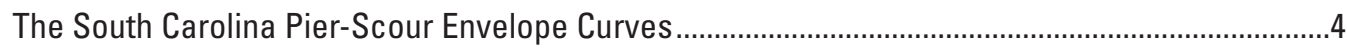

Clear-Water Pier-Scour Envelope Curve ..........................................................................

South Carolina Clear-Water Pier-Scour Field Data..........................................................

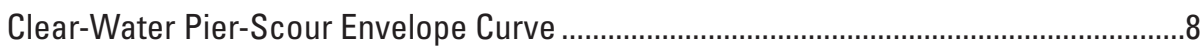

Live-Bed Pier-Scour Envelope Curve ………………….....................................................

South Carolina Live-Bed Pier-Scour Field Data ................................................................

Live-Bed Pier-Scour Envelope Curve ..............................................................................11

Comparison of the South Carolina Pier-Scour Envelope Curves With Other Data ..............................13

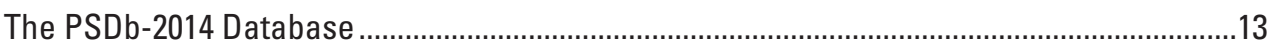

South Carolina Clear-Water and Live-Bed Pier-Scour Field Data...................................13

Screened Laboratory and Field Data.............................................................................16

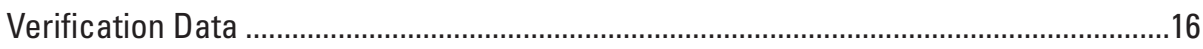

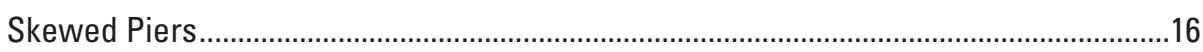

The PSDb-2014 Pier-Scour Envelope Curve ........................................................................17

Envelope Curve for the PSDb-2014 Screened Laboratory Pier-Scour Data ....................17

Extending the Envelope Curve With the PSDb-2014 Screened Field Data.......................17

Verifying the Envelope Curve With the PSDb-2014 Unscreened Field Data .......................19

Review of Field Data That Exceed the Envelope Curve.................................................19

Flow Recurrence Intervals for Data Used in the PSDb-2014 Pier-Scour

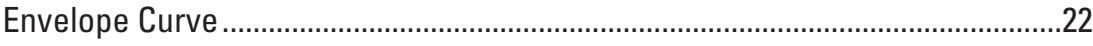

Comparison of the South Carolina and PSDb-2014 Pier-Scour Envelope Curves......................22

Relative Increase in Theoretical Pier Scour Associated With the 100- to 500-Year Flows.............24

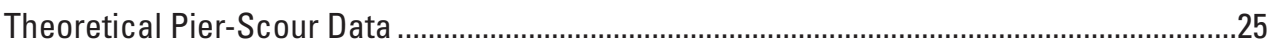

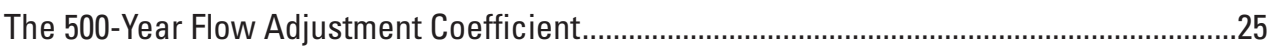

Application and Limitations of the PSDb-2014 and South Carolina Clear-Water

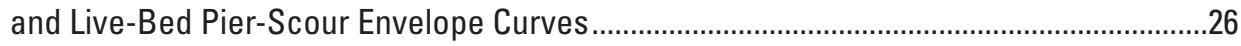

Evaluating Scour Depth at Pier Widths Less Than or Equal to 6 Feet ......................................26

Clear-Water Pier Scour on the Flood Plain.....................................................................27

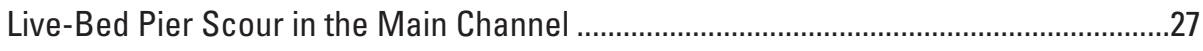

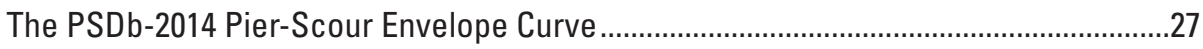

Evaluating Scour Depth at Pier Widths Greater Than 6 Feet ................................................28 
The South Carolina Clear-Water Abutment-Scour Envelope Curves .............................................28

South Carolina Clear-Water Abutment-Scour Field Data .....................................................30

Field Conditions That Influence Clear-Water Abutment-Scour Potential ...............................31

Clear-Water Abutment-Scour Envelope Curves With Respect to Embankment Length .........33

Piedmont Clear-Water Abutment-Scour Envelope Curve ..................................................33

Coastal Plain Clear-Water Abutment-Scour Envelope Curve ............................................35

Clear-Water Abutment-Scour Envelope Curves With Respect to the Geometric-Contraction Ratio ...........................................................................................35

Piedmont Clear-Water Abutment-Scour Envelope Curve ...............................................37

Coastal Plain Clear-Water Abutment-Scour Envelope Curve ............................................37

The Modified Clear-Water Abutment-Scour Envelope Curves .................................................37

Comparison of the South Carolina Clear-Water Abutment-Scour Envelope Curves

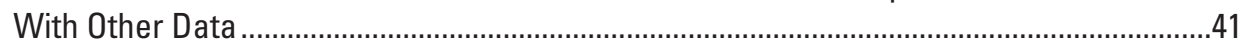

Comparison of the Clear-Water Abutment-Scour Field Data to Laboratory Data ...................43

Discrepancies in the Upper Bound of the Clear-Water Abutment-Scour

Laboratory and Field Data

Comparison of the South Carolina Abutment-Scour Envelope Curves to

Other Abutment-Scour Field Data ..............................................................................45

Relative Increase in Theoretical Abutment Scour Associated With the

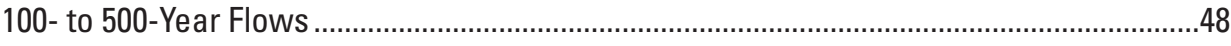

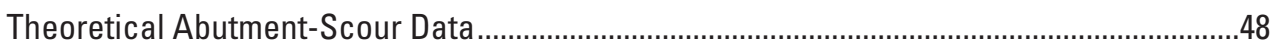

The 500-Year Flow Adjustment Coefficient.........................................................................4

Application and Limitations of the South Carolina Clear-Water Abutment-Scour

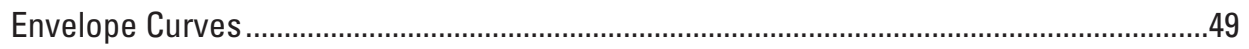

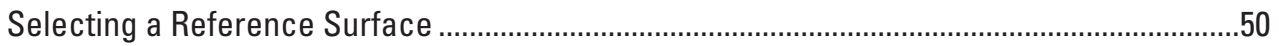

Estimating the Embankment Length and the Geometric-Contraction Ratio ...........................50

Selecting the Appropriate Clear-Water Abutment-Scour Envelope Curve .............................50

Original Clear-Water Abutment-Scour Envelope Curves...............................................50

Modified Clear-Water Abutment-Scour Envelope Curves................................................51

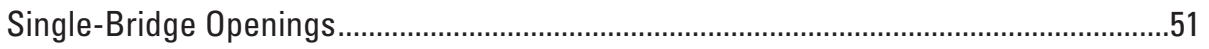

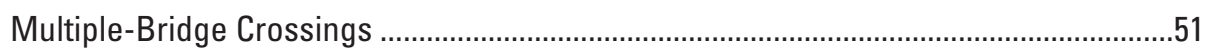

Contraction and Pier Scour Within the Clear-Water Abutment-Scour Region ...................52

Top Width of Abutment-Scour Hole .........................................................................53

Limitations of the South Carolina Clear-Water Abutment-Scour Envelope Curves ........53

The South Carolina Clear-Water Contraction-Scour Envelope Curve ...............................................55

South Carolina Clear-Water Contraction-Scour Field Data ..................................................5

Clear-Water Contraction-Scour Envelope Curve ................................................................56

Comparison of the South Carolina Clear-Water Contraction-Scour Envelope Curve

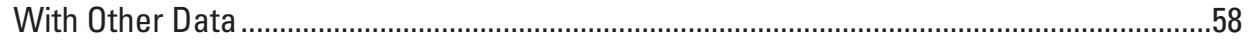

Relative Increase in Theoretical Clear-Water Contraction Scour Associated With

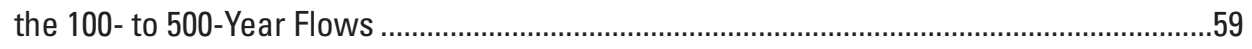

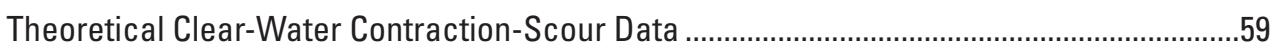

The 500-Year Flow Adjustment Coefficient........................................................................59

Application and Limitations of the South Carolina Clear-Water Contraction-Scour

Envelope Curve 
Selecting a Reference Surface for Clear-Water Contraction Scour ......................................61

Pier Scour Within Clear-Water Contraction-Scour Areas...................................................61

Estimate of Clear-Water Contraction-Scour Hole Location .....................................................62

The South Carolina Live-Bed Contraction-Scour Envelope Curves....................................................62

South Carolina Live-Bed Contraction-Scour Field Data...........................................................62

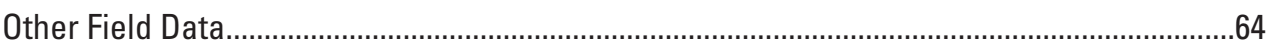

Live-Bed Contraction-Scour Envelope Curves ........................................................................64

Dimensionless Live-Bed Contraction-Scour Envelope Curves ......................................65

Field Envelope Curve for Live-Bed Contraction Scour ....................................................67

The Modified Live-Bed Contraction-Scour Envelope Curve ...........................................67

Relative Increase in Theoretical Live-Bed Contraction Scour Associated

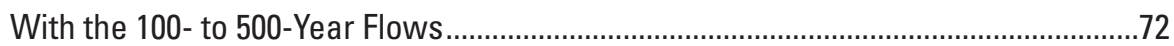

Theoretical Live-Bed Contraction-Scour Data .................................................................

The 500-Year Flow Adjustment Coefficient...................................................................73

Application and Limitations of the South Carolina Live-Bed Contraction-Scour

Envelope Curves ..........................................................................................................

Guidance for Using the South Carolina Bridge-Scour Envelope Curves and Databases ................75

Using the Bridge-Scour Databases for Site Comparisons ....................................................75

Guidance for Applying the South Carolina Bridge-Scour Envelope Curves ............................77

Assessing Clear-Water Scour in the Bridge Overbank .................................................77

Assessing Clear-Water Abutment-Scour Potential .........................................................78

Assessing Clear-Water Contraction-Scour Potential ...................................................80

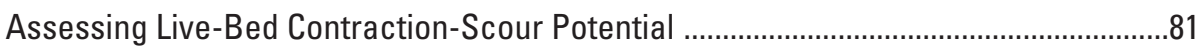

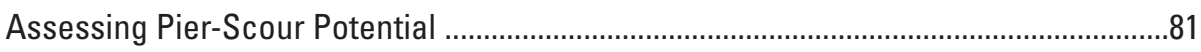

Limitations of the South Carolina Bridge-Scour Envelope Curves .................................82

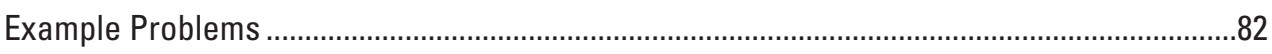

Example 1: Coosawhatchie River at Road S-87 in Jasper County...................................83

Clear-Water Abutment-Scour Potential...................................................................83

Abutment Scour-Hole Top Width...........................................................................

Clear-Water Contraction-Scour Potential ..............................................................

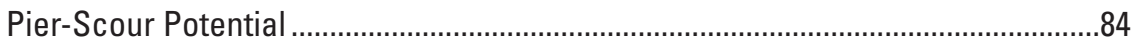

Clear-Water Abutment Region................................................................................84

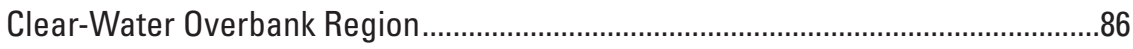

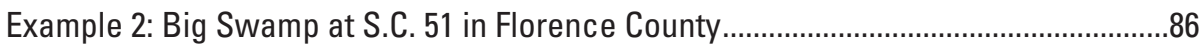

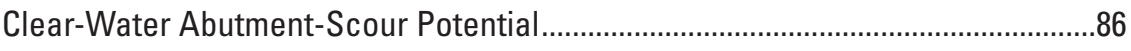

Example 3: Enoree River at Road S-87 in Newberry County.............................................89

Clear-Water Abutment-Scour Potential....................................................................

Clear-Water Contraction-Scour Potential .................................................................91

Clear-Water Pier Scour for the Right Overbank ....................................................91

Live-Bed Contraction-Scour Potential ..................................................................91

Live-Bed Pier-Scour Potential ..............................................................................91

Summary

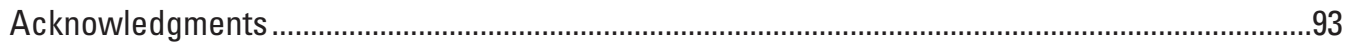

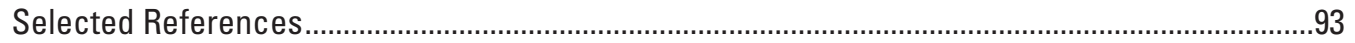




\section{Figures}

1. Map showing location of physiographic provinces and bridge-scour study sites in South Carolina

2. Illustration of scour at a cylindrical pier.

3. Graph showing distribution of the ratio of the average flood plain velocity to the critical velocity of the median grain size for selected bridges in the Coastal Plain and Piedmont of South Carolina

4. Typical bridge cross section with well-defined main channel, showing areas of clear-water and live-bed scour....

5. Typical bridge cross section for a swampy channel or flood plain relief bridge, showing area of clear-water scour

6. Diagram showing definition of nominal and effective pier width

7-20. Graphs showing-

7. The South Carolina clear-water pier-scour envelope curve

8. Distribution of the ratio of the average main-channel velocity to the critical velocity of the median grain size for selected bridges in the Coastal Plain and Piedmont of South Carolina

9. Example of ground-penetrating radar pier-scour profile at South Carolina Department of Transportation structure 364012100101 on S.C. Route 121 crossing the Saluda River in Newberry County, South Carolina

10. The South Carolina live-bed pier-scour envelope curve

11. Relation of relative scour to the dimensionless variable for laboratory data used to develop the original HEC-18 pier-scour equation and clear-water and live-bed pier-scour data from selected sites in South Carolina

12. Comparison of the South Carolina live-bed pier-scour envelope curve with the envelope curve developed from selected field data from the National Bridge Scour Database

13. Relation of scour depth to pier width for the screened laboratory data from the PSDb-2014 database

14. Relation of scour depth to pier width for the screened laboratory and field data from the PSDb-2014 database

15. Relation of scour depth to pier width for the screened laboratory and field data and verification data from the PSDb-2014 database

16. Relation of scour depth to pier width for the screened laboratory and field data and verification data from the PSDb-2014 database

17. The PSDb-2014 pier-scour envelope curve with field data grouped by recurrence interval

18. Comparison of the South Carolina clear-water and the PSDb-2014 pier-scour envelope curves

19. Comparison of the South Carolina live-bed and the PSDb-2014 pier-scour envelope curves

20. Relation of the 500- and 100 -year flow, theoretical pier-scour depths for selected data from level-2 bridge-scour studies in South Carolina and Missouri 
21. Block diagram showing flow around a bridge abutment and embankment and resulting scour

22. Diagram showing plan view of simplified flow field at a bridge contraction .................29

23. Diagram showing plan view of regions of clear-water abutment and contraction scour

24. Diagram showing example of single scour hole at shorter bridges, as shown at structure 212030100100 on U.S. Route 301 crossing Douglas Swamp in Florence County, South Carolina, July 31, 1996

25. Diagram showing example of separate left and right abutment-scour holes at longer bridges in the Coastal Plain, as shown at structure 277008700100 on Road S-87 crossing the Coosawhatchie River in Jasper County, South Carolina, November 12, 1997

26. Graph showing the South Carolina Piedmont clear-water abutment-scour envelope curve with respect to the embankment length blocking flow

27. Graph showing the South Carolina Coastal Plain clear-water abutment-scour envelope curve with respect to the embankment length blocking flow

28. Diagram showing definition of the embankment length blocking flow determined by projection of the bridge cross section onto the upstream approach cross section

29. Diagram showing definition of the geometric-contraction ratio 35

30-43. Graphs showing-

30. The South Carolina Piedmont clear-water abutment-scour envelope curve with respect to the geometric-contraction ratio

31. The South Carolina Coastal Plain clear-water abutment-scour envelope curve with respect to the geometric-contraction ratio

32. Relation of clear-water abutment-scour depth to the geometriccontraction ratio for field data associated with selected embankment lengths used to develop the South Carolina modified abutment-scour envelope curves

33. Relation of clear-water abutment-scour depth to the geometriccontraction ratio for selected categories of embankment lengths in the Piedmont of South Carolina

34. Relation of clear-water abutment-scour depth to the geometriccontraction ratio for selected categories of embankment lengths in the Coastal Plain of South Carolina

35. Relation of the relative abutment-scour depth to relative abutment length for selected laboratory data

36. Relation of the relative abutment-scour depth to relative abutment length for selected laboratory and field data

37. Comparison of the South Carolina abutment-scour envelope curves for geometric-contraction ratio to field data from other sources . .45

38. Comparison of the South Carolina abutment-scour envelope curves for embankment length to field data from other sources.

39. Comparison of the South Carolina abutment-scour envelope curves for embankment length to field data from other sources 
40. Relation of abutment-scour depth to drainage area for selected field data 47

41. Relation of the 100- and 500-year flow, theoretical abutment-scour depths for selected data from level-2 bridge-scour studies in South Carolina and Missouri.

42. Relation of abutment scour-hole top width and abutment-scour depth at bridges greater than 240 feet in length and swampy and flood plain relief bridges, 240 feet or less in length, in the Piedmont and Coastal Plain of South Carolina

43. The South Carolina clear-water contraction-scour envelope curve for the Piedmont and Coastal Plain

44. Diagram showing example of clear-water abutment- and contraction-scour areas at structure 274000300200 on S.C. Route 3 crossing Cypress Creek in Jasper County

45-54. Graphs showing-

45. Comparison of the South Carolina clear-water contraction-scour envelope curve with field data from other sources

46. Relation of the 100 - and 500 -year flow, theoretical clear-water contraction-scour depths for selected data from level-2 bridge-scour studies in South Carolina and Missouri

47. Example of ground-penetrating radar longitudinal profile at structure 262050110100 on U.S. Route 501 crossing the Little Pee Dee River in Horry County, South Carolina

48. The South Carolina dimensionless live-bed contraction-scour envelope curve for live-bed and clear-water contraction-scour data, and live-bed contraction-scour data only

49. The South Carolina live-bed contraction-scour envelope curve for live-bed contraction-scour data, and live-bed and clear-water contraction-scour data

50. The South Carolina live-bed contraction-scour envelope curve for the "worst case scour" for the live-bed contraction-scour data

51. Relation of contraction-scour depth to drainage area for selected field data ......69

52. Relation of live-bed contraction-scour depth to the geometric-contraction ratio for selected field data for drainage areas 100 square miles or less, and drainage areas 200 square miles or less

53. Relation of live-bed contraction-scour depth to the geometric-contraction ratio for selected categories of drainage area for selected data in the Piedmont and Coastal Plain of South Carolina

54. Relation of the 100 - and 500-year flow, theoretical live-bed contractionscour depths for selected data from level-2 bridge-scour studies in South Carolina and Missouri 
55-66. Diagrams showing-

55. Bridge site information for example 1, Coosawhatchie River at Road S-87 in Jasper County, South Carolina .

56. Approach section information for example 1, Coosawhatchie River at Road S-87 in Jasper County, South Carolina, showing bridge top width and road embankment locations projected onto the approach cross section

57. Region of potential scour determined from South Carolina bridge-scour envelope curves for example 1, Coosawhatchie River at Road S-87 in Jasper County, South Carolina

58. Region of potential scour determined from the South Carolina bridge-scour envelope curves for example 1, Coosawhatchie River at Road S-87 in Jasper County, South Carolina, with the 500-year flow adjustment coefficient applied

59. Bridge site information for example 2, Big Swamp at S.C. 51 in Florence County, South Carolina

60. Approach section information for example 2, Big Swamp at S.C. 51 in Florence County, South Carolina, showing bridge top width and road embankment locations projected onto the approach cross section

61. Region of potential scour determined from the South Carolina bridge-scour envelope curves for example 2, Big Swamp at S.C. 51 in Florence County, South Carolina

62. Region of potential scour determined from the South Carolina bridge-scour envelope curves for example 2, Big Swamp at S.C. 51 in Florence County, South Carolina, with the 500-year flow adjustment coefficient applied

63. Bridge site information for example 3, Enoree River at Road S-87 in Newberry County, South Carolina

64. Approach section information for example 3, Enoree River at Road S-87 in Newberry County, South Carolina, showing bridge top width and road embankment locations projected onto the approach cross section

65. Region of potential scour determined from South Carolina bridge-scour envelope curves for example 3, Enoree River at Road S-87 in Newberry County, South Carolina

66. Region of potential scour determined from the South Carolina bridge-scour envelope curves for example 3, Enoree River at Road S-87 in Newberry County, South Carolina, with the 500-year flow adjustment coefficient applied...... 


\section{Tables}

1. Range of selected characteristics of clear-water pier scour field data collected in the flood plains of selected sites in South Carolina

2. Range of selected characteristics of live-bed pier scour field data collected in the main channels of selected sites in South Carolina.

3. Range of selected characteristics for the laboratory measurements of pier scour compiled in the PSDb-2014

4. Range of selected characteristics for the field measurements of pier scour compiled in the PSDb-2014

5. Review of selected data points exceeding the PSDb-2014 pier-scour envelope curve.

6. Descriptive statistics for the ratio of the 500- and 100 -year flow, theoretical pier-scour depths used in the regression analysis for selected data from South Carolina and Missouri .....

7. Range of selected characteristics of clear-water abutment scour field data in the flood plains of selected sites in South Carolina

8. Range of selected site characteristics for field measurements of abutment scour used to develop the modified clear-water abutment-scour envelope curves.

9. Equations for the modified clear-water abutment-scour envelope curves in the Piedmont and Coastal Plain of South Carolina.

10. Range of characteristics for selected laboratory abutment-scour data

11. Range of characteristics for selected abutment-scour measurements from Maine, Alabama, the National Bridge Scour Database, and the Missouri River Interstate-70 Bridge.

12. Descriptive statistics for the ratio of the 500- and 100-year flow, theoretical abutment-scour depths used in the regression analysis for selected theoretical data from South Carolina and Missouri

13. Range of selected characteristics of clear-water contraction scour field data collected in the flood plains of selected sites in South Carolina

14. Range of selected characteristics of clear-water contraction scour field data used for comparison with the South Carolina clear-water contraction-scour data

15. Descriptive statistics for the ratio of the 500- and 100-year flow, theoretical clear-water contraction-scour depths used in the regression analysis for selected theoretical data from South Carolina and Missouri.

16. Range of selected characteristics of live-bed contraction scour field data collected in the main channels of selected sites in South Carolina

17. Range of selected characteristics for field measurements of contraction scour used to help confirm the patterns of the South Carolina live-bed contraction-scour data 64

18. Range of selected site characteristics for field measurements of contraction scour used to develop the modified live-bed contraction-scour envelope curves

19. Equations used to develop the modified live-bed contraction-scour envelope curve in the Piedmont and Coastal Plain of South Carolina 
20. Descriptive statistics for the ratio of the 500- and 100-year flow, theoretical live-bed contraction-scour depths used in the regression analysis for selected theoretical data from South Carolina and Missouri. .73

21. Internet addresses for the South Carolina bridge-scour databases 76

22. Example of comparison scour data obtained from the South Carolina bridgescour databases for sites in Spartanburg County, South Carolina.

\section{Digital Data in Excel Format}

[Available for downloading from https://doi.org/10.3133/sir20165121]

Appendix 1. South Carolina bridge-scour study sites and reference numbers for figure 1 .

Appendix 2. Estimate of maximum historic flows at selected bridge crossings in South Carolina.

\section{Conversion Factors}

U.S. customary units to International System of Units

\begin{tabular}{lcl}
\hline \multicolumn{1}{c}{ Multiply } & By & \multicolumn{1}{c}{ To obtain } \\
\hline inch (in.) & Length & millimeter $(\mathrm{mm})$ \\
foot (ft) & 25.4 & meter $(\mathrm{m})$ \\
mile (mi) & 0.3048 & kilometer $(\mathrm{km})$ \\
\hline & 1.609 & \\
\hline square foot $\left(\mathrm{ft}^{2}\right)$ & Area & square meter $\left(\mathrm{m}^{2}\right)$ \\
square mile $\left(\mathrm{mi}^{2}\right)$ & 0.09290 & square kilometer $\left(\mathrm{km}^{2}\right)$ \\
\hline & 2.590 & \\
\hline cubic foot $\left(\mathrm{ft}^{3}\right)$ & Volume & cubic meter $\left(\mathrm{m}^{3}\right)$ \\
\hline & 0.02832 & \\
\hline cubic foot per second $\left(\mathrm{ft}^{3} / \mathrm{s}\right)$ & Flow rate & cubic meter per second $\left(\mathrm{m}^{3} / \mathrm{s}\right)$ \\
\hline
\end{tabular}

\section{Datums}

Vertical coordinate information is referenced to the National Geodetic Vertical Datum of 1929 (NGVD 29) or North American Vertical Datum of 1988 (NAVD 88).

Horizontal coordinate information is referenced to the North American Datum of 1927 or 1983 (NAD 27 or NAD 83, respectively).

Elevation, as used in this report, refers to distance above the vertical datum or to distance above an arbitrary datum. 


\section{Abbreviations}

$\begin{array}{ll}\text { FHWA } & \text { Federal Highway Administration } \\ \text { GPR } & \text { ground-penetrating radar } \\ \text { HEC-18 } & \text { Hydraulic Engineering Circular No. 18 } \\ \text { NBSD } & \text { National Bridge Scour Database } \\ \text { PSDb-2014 } & \text { 2014 USGS Pier Scour Database } \\ \text { SCDOT } & \text { South Carolina Department of Transportation } \\ \text { SCLBSD } & \text { South Carolina Live-Bed Scour Database } \\ \text { SCPCSD } & \text { South Carolina Clear-Water Pier- and Contraction-Scour Database } \\ \text { USGS } & \text { U.S. Geological Survey } \\ \text { WSPRO } & \text { Water-Surface Profile model }\end{array}$




\title{
The South Carolina Bridge-Scour Envelope Curves
}

\author{
By Stephen T. Benedict, Toby D. Feaster, and Andral W. Caldwell
}

\section{Abstract}

The U.S. Geological Survey, in cooperation with the South Carolina Department of Transportation, conducted a series of three field investigations to evaluate historical, riverine bridge scour in the Piedmont and Coastal Plain regions of South Carolina. These investigations included data collected at 231 riverine bridges, which lead to the development of bridge-scour envelope curves for clear-water and live-bed components of scour. The application and limitations of the South Carolina bridge-scour envelope curves were documented in four reports, each report addressing selected components of bridge scour. The current investigation (2016) synthesizes the findings of these previous reports into a guidance manual providing an integrated procedure for applying the envelope curves. Additionally, the investigation provides limited verification for selected bridge-scour envelope curves by comparing them to field data collected outside of South Carolina from previously published sources. Although the bridge-scour envelope curves have limitations, they are useful supplementary tools for assessing the potential for scour at riverine bridges in South Carolina.

\section{Introduction}

The U.S. Geological Survey (USGS), in cooperation with the South Carolina Department of Transportation (SCDOT), investigated historical scour at 231 bridges in the Piedmont and Coastal Plain Physiographic Provinces of South Carolina (Benedict, 2003; Benedict and Caldwell, 2006, 2009, 2012). (In this report, the Piedmont and Coastal Plain Physiographic Provinces will be referred to simply as Piedmont and Coastal Plain.) Historical-scour measurements represent the maximum scour depth, for a given scour component, that has occurred over the life of a bridge at the time of the scour measurement. A series of bridge-scour studies were conducted from 2003 to 2012, the general objectives of which were to (1) collect field measurements of historical abutment, contraction, and pier scour at sites that could be associated with major floods and (or) older bridges, (2) use the field data to assess the performance of the scour-prediction equations listed in the Federal
Highway Administration (FHWA) Hydraulic Engineering Circular No. 18 (HEC-18 [fourth edition]; Richardson and Davis, 2001), and (3) develop supplementary tools derived from the field data to help assess scour potential in the Piedmont and Coastal Plain regions of South Carolina.

The results from these previous investigations showed that the HEC-18 scour-prediction equations, in general, overpredicted scour depths and were at times excessive. In some cases, however, substantial underprediction occurred, indicating that the equations could not be relied upon to consistently give conservative and reasonable estimates of scour. Although the HEC-18 equations provide a valuable resource for assessing scour, the trends in the analysis highlighted the need for engineering judgment to determine if predicted scour is reasonable. To assist engineers in developing and applying such judgment, the data collected from the South Carolina field investigations were organized into regional bridge-scour envelope curves that displayed the range and trend for the upper bound of observed scour for each scour component, including clear-water abutment, contraction, and pier scour, as well as live-bed contraction and pier scour. The application and limitations of the South Carolina bridge-scour envelope curves were documented in four reports (Benedict, 2003; Benedict and Caldwell, 2006, 2009, 2012), with each report addressing different components of bridge scour. A primary objective of the current investigation (2016) was to synthesize the findings of these previously published reports into a single guidance manual providing an integrated procedure for applying the South Carolina bridgescour envelope curves. In addition to the guidance manual, a companion spreadsheet was developed to facilitate application of this integrated procedure. Additional objectives of the investigation were to (1) evaluate the South Carolina bridgescour envelope curves by comparing them to bridge-scour data outside of South Carolina from previously published sources, (2) develop 500-year recurrence-interval flow bridge-scour envelope-curve coefficients for each scour component (defined later in the report), and (3) merge the three previously published databases (Benedict, 2003; Benedict and Caldwell, 2006, 2009) into a format that later could be incorporated into an integrated Web-based GIS application such as StreamStats (Ries and others, 2008) to provide a user-friendly format for accessing the data. 


\section{Purpose and Scope}

The purpose of this report is to describe (1) the

previously developed bridge-scour envelope curves and their evaluation with data from other sources, (2) the development of the 500-year flow bridge-scour envelope-curve coefficients, (3) guidance for applying the bridge-scour envelope curves, and (4) the companion spreadsheet for applying the South Carolina bridge-scour envelope curves, which is available for download at http://dx.doi.org/10.3133/sir20165121.

\section{Description of the Study Area}

South Carolina encompasses an area of about 31,100 square miles $\left(\mathrm{mi}^{2}\right)$ and is divided into three physiographic provinces - the Blue Ridge, Piedmont, and Coastal Plain (fig. 1). The Coastal Plain can be further divided into upper and lower regions (Bloxham, 1976). The study area for this investigation includes most of South Carolina but generally excludes the Blue Ridge and the tidally influenced area of the lower Coastal Plain.

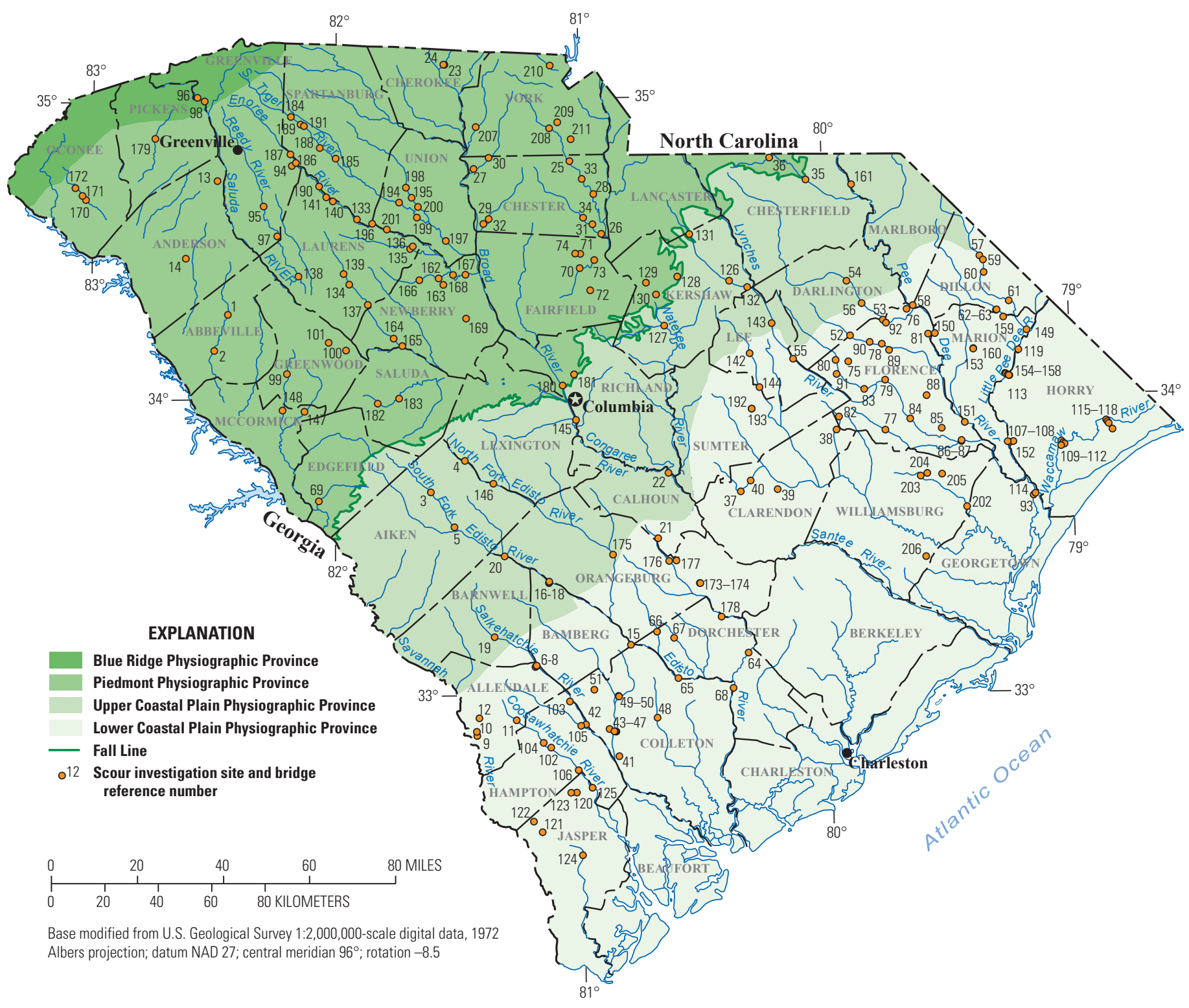

Figure 1. Location of physiographic provinces and bridge-scour study sites in South Carolina. (Refer to appendix 1, which is available for downloading from http://dx.doi.org/10.3133/sir20165121, to identify bridge with corresponding number.) 
The Piedmont covers approximately 35 percent of South Carolina and lies between the Blue Ridge and Coastal Plain (fig. 1). Land-surface elevations range from about 400 feet (ft) near the Fall Line, which is the name given to the boundary between the Piedmont and upper Coastal Plain, to about 1,000 ft at the Blue Ridge boundary. The general topography includes rolling hills, elongated ridges, and moderately deep to shallow valleys. The drainage patterns are well developed with well-defined channels and densely vegetated flood plains. Streambed slopes in the Piedmont range from approximately 0.001 to 0.011 foot per foot (ft/ft) (Guimaraes and Bohman, 1992). The geology of the Piedmont generally consists of fractured crystalline rock overlain by moderately to poorly permeable silty-clay loams. Alluvial deposits along the valley floors consist of clay, silt, and sand, and form varying degrees of cohesive soils (Guimaraes and Bohman, 1992). The stream channel sediments typically consist of sandy materials overlaying decomposed rock or bedrock.

The upper Coastal Plain lies between the Piedmont and lower Coastal Plain, and covers approximately 20 percent of the State (fig. 1). The general topography in the upper Coastal Plain consists of rounded hills with gradual slopes and land-surface elevations that range from less than $200 \mathrm{ft}$ to more than $700 \mathrm{ft}$. The geology consists primarily of sedimentary rocks composed of layers of sand, silt, clay, and gravel underlain by igneous rocks (Zalants, 1990). A shallow surface layer of permeable sandy soils is common. Low-flow stream channels bounded by densely vegetated flood plains characterize upper Coastal Plain streams, and the channel sediments typically consist of sandy materials overlying rock. Streambed slopes are moderate, ranging from approximately 0.001 to $0.0038 \mathrm{ft} / \mathrm{ft}$ (Guimaraes and Bohman, 1992).

The lower Coastal Plain covers about 43 percent of the State (fig. 1). The topographic relief of the lower Coastal Plain is less pronounced than that of the upper Coastal Plain, and landsurface elevations range from $0 \mathrm{ft}$ at the coast to nearly $200 \mathrm{ft}$ at the boundary with the upper Coastal Plain. The geology of the lower Coastal Plain consists of loosely consolidated sedimentary rocks of sand, silt, clay, and gravel overlain by permeable sandy soils (Zalants, 1991). As in the upper Coastal Plain, the low-flow stream channels bounded by densely vegetated flood plains characterize the lower Coastal Plain streams, and the channel sediments typically consist of sandy materials overlying sedimentary rock. Streambed slopes range from approximately 0.0002 to $0.0038 \mathrm{ft} / \mathrm{ft}$, and streamflow patterns are tidally influenced near the coast (Guimaraes and Bohman, 1992).

\section{Previous Investigations}

The USGS, in cooperation with the SCDOT, has conducted six previous investigations of bridge scour in South Carolina. In the first investigation of level-1 bridge scour (1990-92), limited structural, hydraulic, geomorphic, and vegetative data were collected at 3,506 bridges and culverts in South Carolina, and observed- and potential-scour indexes were developed for each site (Hurley, 1996). These indexes, along with other variables, were used by the SCDOT to identify bridges that may be susceptible to scour and potentially require a more detailed analysis. In the second cooperative investigation of level-2 bridge scour (1992-95), detailed bridge-scour studies of 293 bridges in South Carolina were conducted by using methods presented in HEC-18 (Richardson and others, 1991, 1993), and these evaluations were used to assess the vulnerability of a bridge to scour. The level-1 and level-2 bridge-scour studies gave a qualitative overview of scour, which helped form general concepts of the type, magnitude, and frequency of scour throughout South Carolina. In addition, the level-2 bridge-scour studies provided anecdotal evidence of the apparent discrepancy between the predicted and measured scour. These findings indicated a need to better understand the trends of scour within the field, which lead to a series of three field investigations (1996-2009) of historical bridge scour in South Carolina (Benedict, 2003; Benedict and Caldwell, 2006, 2009).

Historical bridge-scour data were collected at 231 bridges in South Carolina as part of the cooperative field investigations (fig. 1) and included 209 measurements (5 were excluded from the envelopes leaving 204 in the analysis) of clear-water abutment scour, 179 measurements of clear-water pier scour, 139 measurements of clear-water contraction scour, 151 measurements ( 10 were excluded from the envelopes leaving 141 in the database) of live-bed pier scour, and 89 measurements of live-bed contraction scour. It should be noted that figure 1 and appendix 1 show only a single location for sites with twin bridges and do not include abandoned bridge structures or railroad bridges near a highway bridge structure for which bridge-scour data may have been collected. The historical data represent the maximum scour depths at the time of the measurement that have occurred at the bridge since construction. The historical scour data were measured during low-flow conditions; therefore, the flood conditions that produced the measured scour were approximated with a one-dimensional step-backwater model. The approximated hydraulic characteristics are less than ideal and may introduce uncertainty in the data analysis, but the large number of data provide a means for assessing general field trends of scour in South Carolina. These data were used to evaluate the performance of the HEC-18 (Richardson and Davis, 2001) scour-prediction equations and to develop the South Carolina bridge-scour envelope curves. Additional details regarding these three field investigations can be found in the associated reports (Benedict, 2003; Benedict and Caldwell, 2006, 2009).

The sixth cooperative investigation of bridge scour in South Carolina involved the modification of several bridge-scour envelope curves to include a family of curves that provide a refined assessment of the upper limit of observed historical scour depths in South Carolina, in particular for sites associated with smaller drainage areas. The modified envelope curves included the clear-water abutment-scour and live-bed contraction-scour envelope curves. Benedict and Caldwell (2012) referred to these family of curves as "secondary envelope curves" to indicate their modification from the original curves. The phrase "secondary envelope curve" also is used in this report for the same purpose. A description of these envelope curves and the techniques used to develop them can be found in Benedict and Caldwell (2012). 


\section{The South Carolina Pier-Scour Envelope Curves}

Local bridge scour is the erosion of streambed material from around flow obstructions, such as a pier. The mechanism that causes the erosion is the combined effect of flow acceleration and the resulting vortexes that are induced by the obstructions (Arneson and others, 2012). In the case of piers, three principal flow features contribute to the development of scour: down flow at the face of the pier, the horseshoe vortex at the bottom of the pier, and the wake vortexes downstream from the pier (Melville and Coleman, 2000; Arneson and others, 2012; fig. 2). The down flow acts like a vertical jet eroding sediments at the pier face. The eroded sediments then are transported by the horseshoe vortex past the pier and into the area of the wake vortexes. Melville and Coleman (2000) describe the wake vortexes as vacuum cleaners that can erode bed sediments downstream from the pier as well as continue the downstream transportation of the sediments eroded by the down flow. The interaction of these flow patterns creates a scour hole that is located close to the pier base. Pier scour typically is classified as clear-water or live-bed scour, which indicates the sediment-transport conditions along the upstream bed during the scouring process, with clear-water scour conditions having no sediment transport and live-bed having active transport. The prevailing sediment-transport conditions will influence the rate at which pier scour develops; therefore, researchers typically have distinguished between live-bed and clear-water pier scour in their investigations. Although it is important to understand the differences between live-bed and clear-water pier scour, it should be noted that the scour processes are similar and that the maximum values of scour depth associated with these types of pier scour also are similar (Melville and Coleman, 2000; Arneson and others, 2012). Both types of pier scour were studied in the South Carolina field investigations leading to the development of clear-water and live-bed pier-scour envelope curves (Benedict and Caldwell, 2006, 2009, respectively).
Numerous laboratory studies have been done to investigate the variables that influence pier scour, including Laursen and Toch (1956), Neill (1964), National Cooperative Highway Research Program (1970), Breusers and others (1977), Breusers and Raudkivi (1991), Melville and Coleman (2000), and Ettema and others (2011). These authors generally agree that the variables that influence pier scour include the velocity of approaching flow, the depth of approaching flow, flow duration, sediment characteristics, pier geometry, pier alignment with flow, and pier width. Although the flow and sediment characteristics at a pier have some influence on scour, the geometric variable, pier width, has been noted by various investigators to be the prominent variable that influences pier-scour depth (Laursen and Toch, 1956; Melville and Coleman, 2000; Mueller and Wagner, 2005; Ettema and others, 2011; Arneson and others, 2012). Because pier width is considered to be a strong explanatory variable, many researchers have proposed simplified pier-scour prediction equations that use pier width as the only explanatory variable (Larras, 1963; Breusers, 1965; Neill, 1973; Norman, 1975; Breusers and Raudkivi, 1991; Ansari and Qadar, 1994; Melville and Coleman, 2000; Ettema and others, 2011; Arneson and others, 2012). An example of this type of equation is the upper bound of pier scour recommended in HEC-18 (Arneson and others, 2012):

$$
\begin{gathered}
y_{s}=2.4 b, \text { for Froude number } \leq 0.8, \text { and } \\
y_{s}=3.0 b, \text { for Froude number }>0.8,
\end{gathered}
$$

where

$$
\begin{gathered}
y_{s} \begin{array}{l}
\text { is the upper bound of potential pier-scour } \\
\text { depth, in feet, and }
\end{array} \\
b \quad \text { is the pier width, in feet, with the pier } \\
\text { aligned with the approaching flow. }
\end{gathered}
$$

Equation 1 and the equations associated with the aforementioned investigations indicate that researchers have considered pier-scour predictive equations that use pier width as the primary explanatory variable to be reasonable and useful for

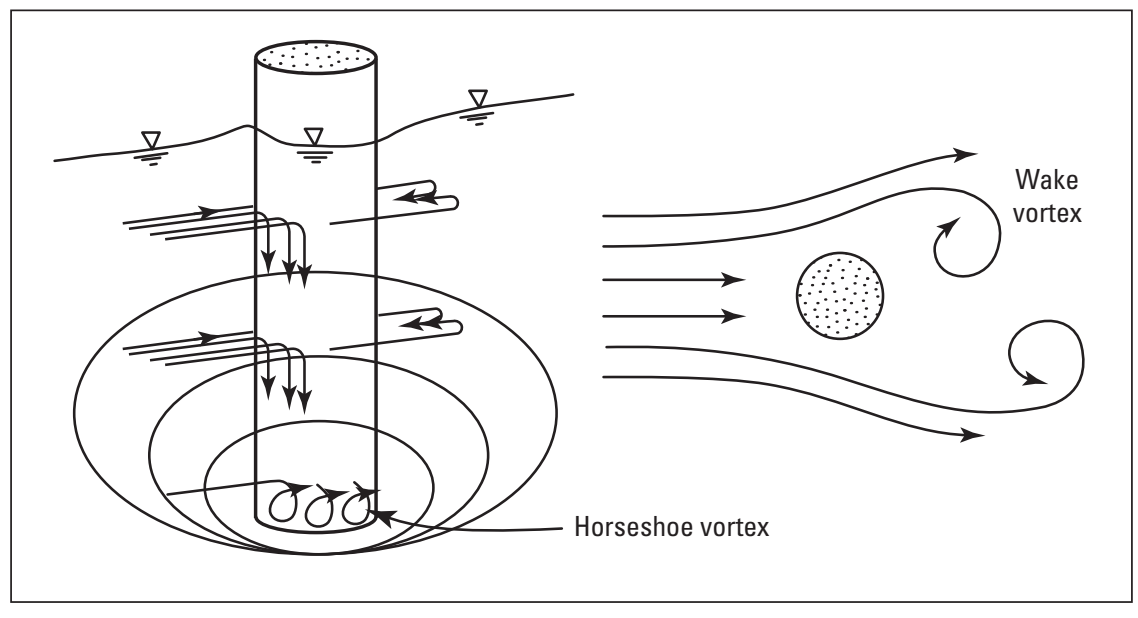

Figure 2. Illustration of scour at a cylindrical pier (from Arneson and others, 2012). 
defining the potential maximum pier-scour depth. Following this pattern, Benedict and Caldwell (2006, 2009) developed field-derived envelope curves for clear-water and live-bed pier scour, using pier width as the primary explanatory variable. An overview of the South Carolina pier-scour envelope curves and a comparison with field data from other sources follow.

\section{Clear-Water Pier-Scour Envelope Curve}

Clear-water scour occurs at a bridge when upstream approach flow velocities are smaller than the critical velocity required to transport bed sediments into the area of scour (Arneson and others, 2012). Such conditions commonly occur on the flood plains of South Carolina streams as illustrated by Benedict and Caldwell (2006; fig. 3). From a sample of 116 bridges from the Coastal Plain and Piedmont regions of South Carolina, the ratio of the 100 -year recurrence interval ${ }^{1}$ (also called the 1-percent annual exceedance probability) flood plain flow velocity to the sediment critical velocity shows that 75 percent of the Piedmont flood plain sites are in clear-water conditions while 25 percent are in live-bed conditions. For the Coastal Plain sites, 96 percent of the flood plain sites are in clear-water conditions. Clear-water scour conditions are

${ }^{1}$ The Federal Highway Administration's manual on scour, HEC-18 (Arneson and others, 2012) uses the term "recurrence interval" rather than "annual exceedance probability" to refer to flood frequency estimates. This convention is used in this report. further promoted by the dense flood plain vegetation typical of South Carolina streams that tends to limit sediment transport, regardless of upstream flow velocities. Because sediment transport is limited, clear-water scour holes have minimal or no infill and, therefore, provide a good record of the maximum historical scour that has occurred at a bridge since construction. Additionally, the minimal infill of the scour holes allows for the direct measurement of the scour depth using standard surveying techniques. In South Carolina, clear-water scour typically occurs on the overbanks at a bridge (fig. 4) or, in the case of a swamp or relief bridge, across the entire bridge opening (fig. 5).

\section{South Carolina Clear-Water Pier-Scour Field Data}

Benedict and Caldwell (2006) made 179 measurements of clear-water pier scour at selected sites in South Carolina, with 87 measurements in the Piedmont and 92 in the Coastal Plain (table 1). Bridge sites where clear-water pier-scour data were collected can be identified in appendix 1 and figure 1 . Measurements of pier-scour depths made in both provinces ranged from 0 to $8.0 \mathrm{ft}$ and were assumed to represent the maximum historical clear-water pier-scour depth that has occurred at the bridge since construction. Nominal pier widths (the width at the frontal pier face with no adjustment for skew; fig. 6) for these data ranged from 0.8 to $6 \mathrm{ft}$. Approximately 80 percent of the data were associated with pile bents having nominal pier widths of $1.5 \mathrm{ft}$ or less. A grab sample of the

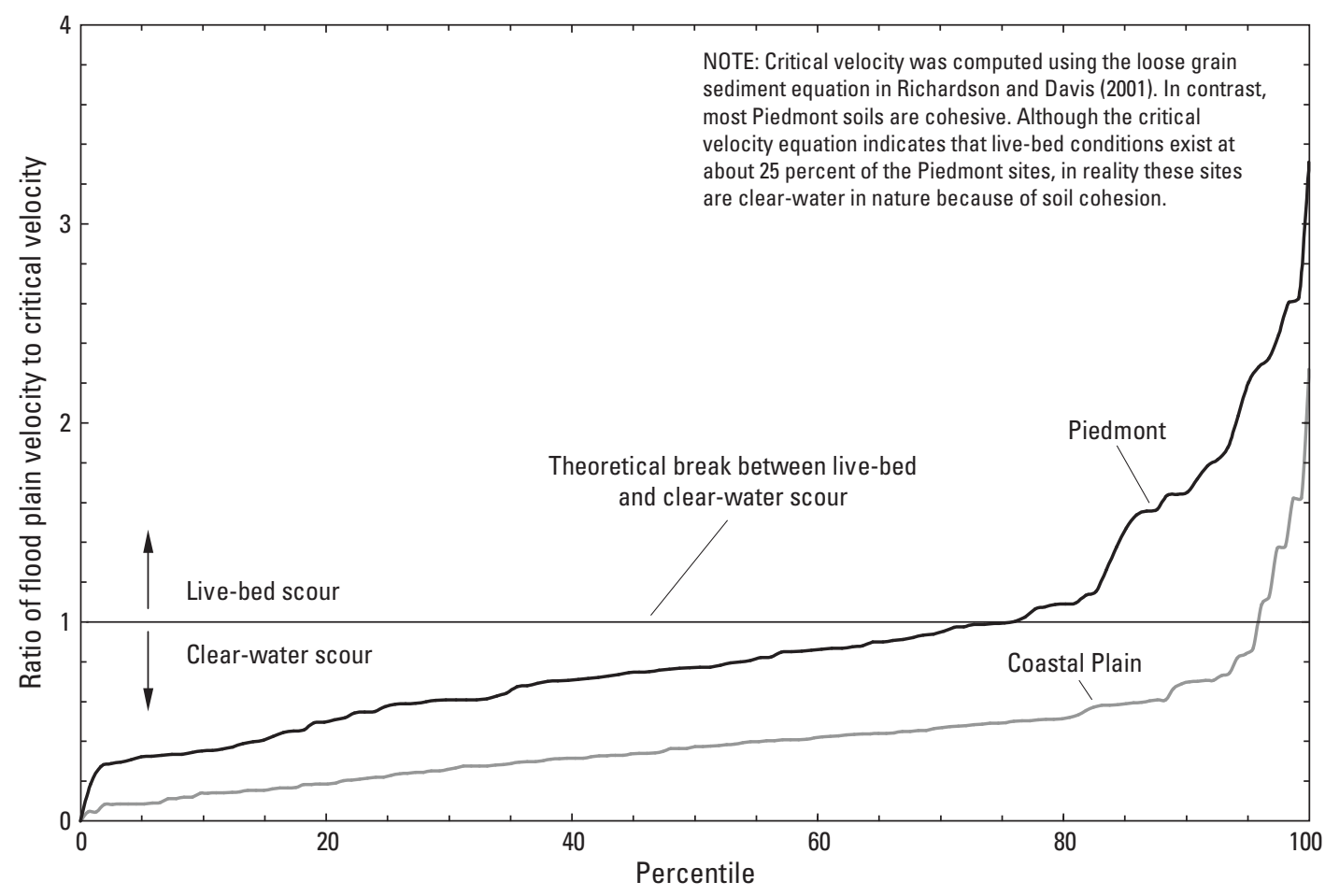

Figure 3. Distribution of the ratio of the average flood plain velocity to the critical velocity of the median grain size for selected bridges in the Coastal Plain and Piedmont of South Carolina (from Benedict and Caldwell, 2006). 


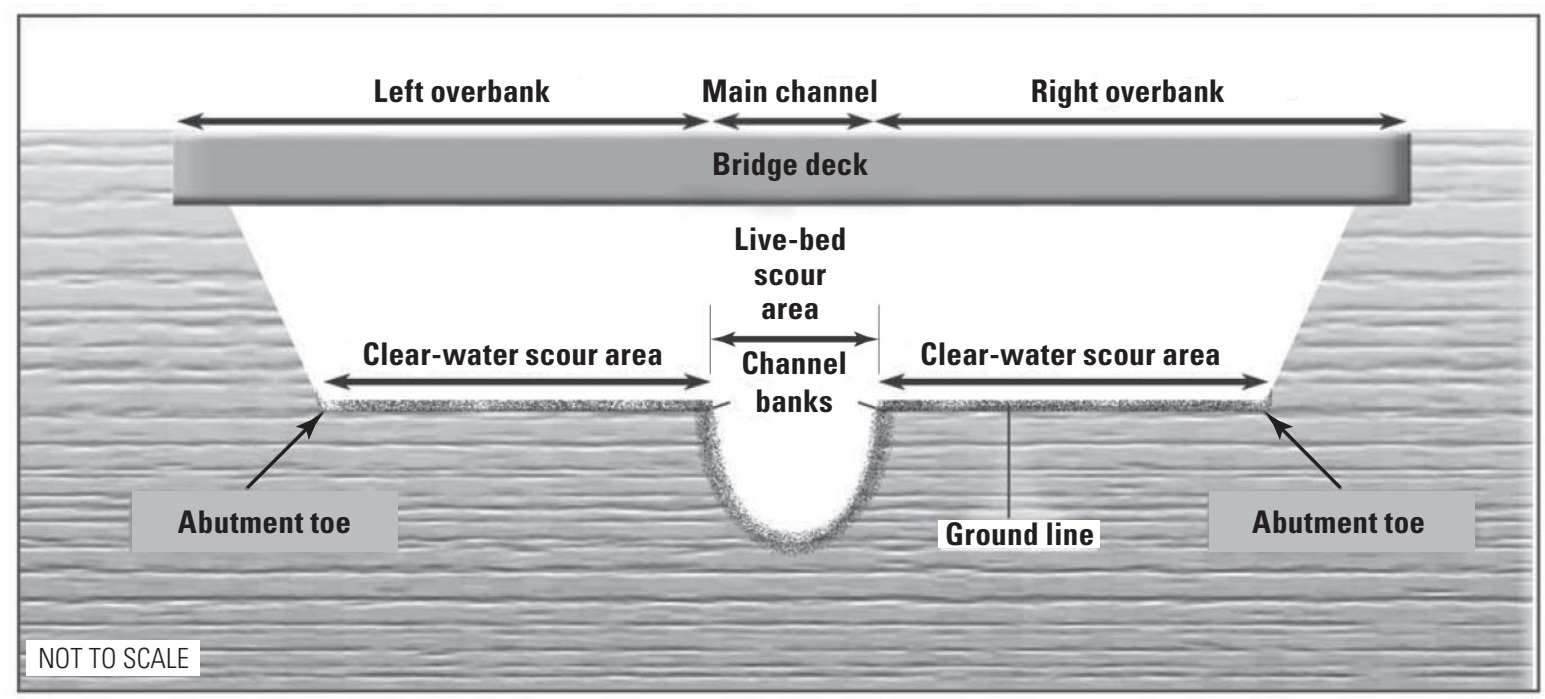

Figure 4. Typical bridge cross section with well-defined main channel, showing areas of clear-water and live-bed scour (from Benedict, 2003).

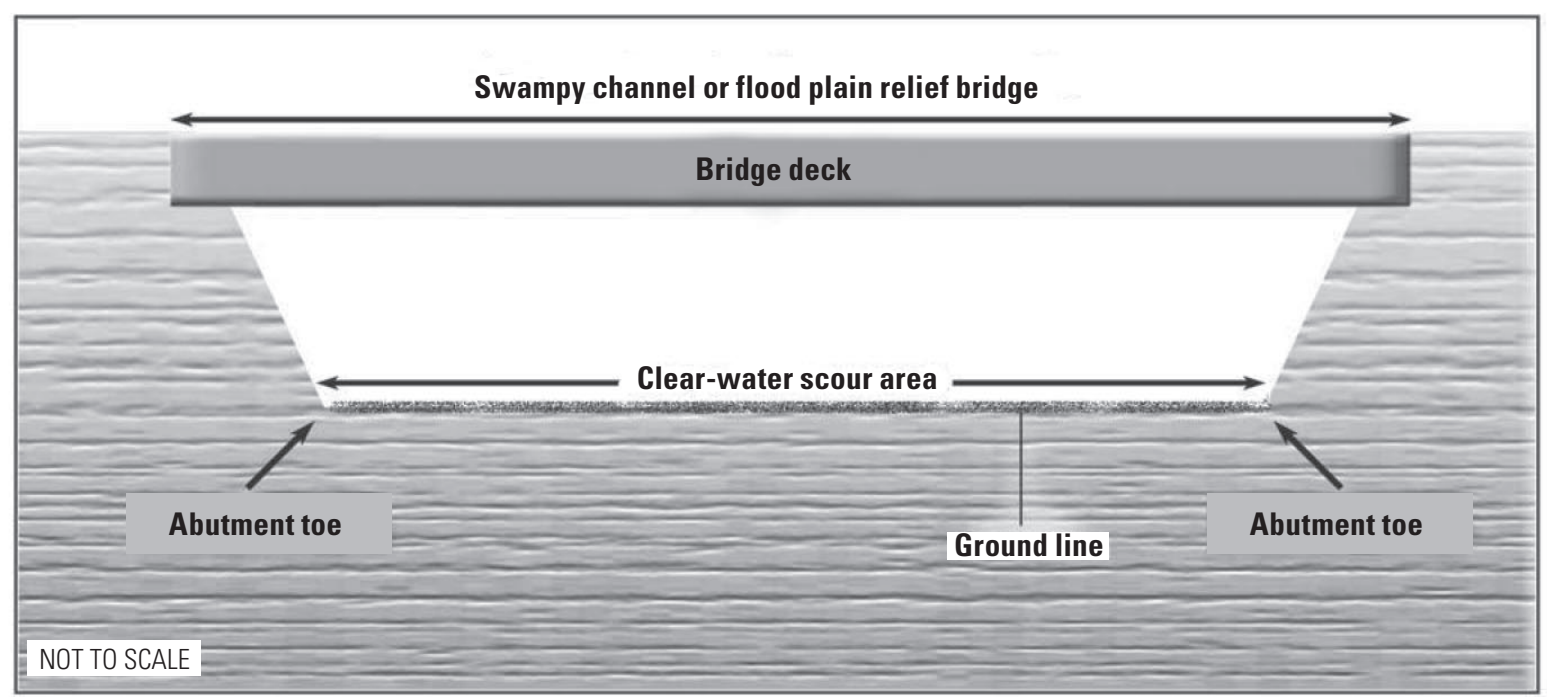

Figure 5. Typical bridge cross section for a swampy channel or flood plain relief bridge, showing area of clearwater scour (from Benedict, 2003). 
Table 1. Range of selected characteristics of clear-water pier scour field data collected in the flood plains of selected sites in South Carolina (Benedict and Caldwell, 2006).

[mi², square mile; $\mathrm{ft} / \mathrm{ft}$, foot per foot; ft/s, foot per second; $\mathrm{ft}$, foot; $\mathrm{mm}$, millimeter; $<$, less than]

\begin{tabular}{|c|c|c|c|c|c|c|c|c|c|}
\hline $\begin{array}{l}\text { Range } \\
\text { value }\end{array}$ & $\begin{array}{c}\text { Drainage } \\
\text { area } \\
\left(\mathrm{mi}^{2}\right)\end{array}$ & $\begin{array}{c}\text { Channel } \\
\text { slope } \\
\text { (ft/ft) }\end{array}$ & $\begin{array}{l}\text { Nominal } \\
\text { pier width } \\
\text { (ft) }\end{array}$ & $\begin{array}{c}\text { Pier skew } \\
\text { (degree) }\end{array}$ & $\begin{array}{l}\text { approach } \\
\text { flow } \\
\text { velocity } \\
\text { (ft/s) }\end{array}$ & $\begin{array}{l}\text { aApproach } \\
\text { flow depth } \\
\text { (ft) }\end{array}$ & $\begin{array}{l}\text { Median } \\
\text { grain size } \\
(\mathrm{mm})\end{array}$ & $\begin{array}{l}\text { Measured } \\
\text { pier-scour } \\
\text { depth } \\
\text { (ft) }\end{array}$ & $\begin{array}{l}\text { Relative } \\
\text { scour depth } \\
\text { (ft) }\end{array}$ \\
\hline \multicolumn{10}{|c|}{ South Carolina Piedmont (87 measurements) } \\
\hline Minimum & 10.7 & 0.00015 & 0.8 & 0.0 & 1.3 & $1.3^{\mathrm{b}}$ & $<0.062$ & 0.0 & 0.1 \\
\hline Median & 81.5 & 0.0012 & 1.0 & 0.0 & 3.1 & $7.7^{\mathrm{b}}$ & 0.105 & 0.85 & 0.7 \\
\hline \multicolumn{10}{|c|}{ South Carolina Coastal Plain (92 measurements) } \\
\hline Minimum & 26.3 & 0.00007 & 0.9 & 0.0 & 0.4 & 2.0 & $<0.062$ & 0.0 & 0.0 \\
\hline Median & 586.0 & 0.0003 & 1.4 & 0.0 & 1.9 & 6.3 & 0.162 & 0.8 & 0.5 \\
\hline Maximum & $13,000^{\mathrm{d}}$ & 0.0009 & 5.0 & 20.0 & 5.4 & 17.3 & 0.556 & 1.8 & 1.3 \\
\hline
\end{tabular}

${ }^{\text {a}}$ Values were estimated from a one-dimensional water-surface profile model.

${ }^{\mathrm{b}}$ This value was misreported in Benedict and Caldwell (2006), but is correctly shown here.

'Approximately 94 percent of the study sites in the Piedmont have drainage areas less than $400 \mathrm{mi}^{2}$.

${ }^{\mathrm{d} A p p r o x i m a t e l y} 80$ percent of the study sites in the Coastal Plain have drainage areas less than $1,420 \mathrm{mi}^{2}$.

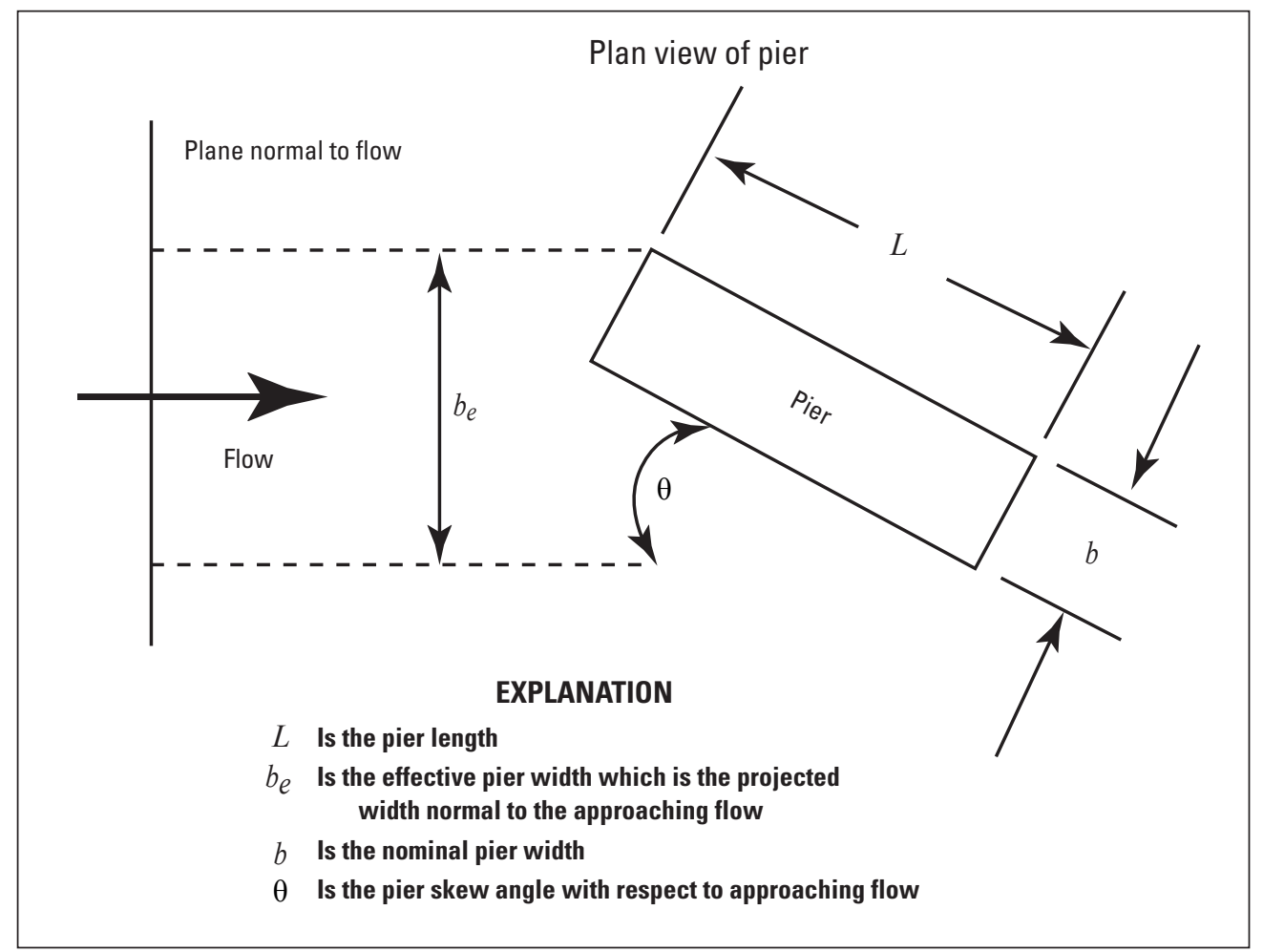

Figure 6. Definition of nominal and effective pier width (modified from Sheppard and others, 2011). 
flood plain surface sediment was obtained in the upstream flood plain at each site and was analyzed to estimate the median grain size. Because sediment characteristics in the field setting can vary substantially in the vertical and horizontal direction, a grab sample taken at a point may not fully represent the sediment characteristics at a site.

To provide some assurance that measured historical scour reflected scour resulting from high flows, Benedict and Caldwell (2006) collected pier-scour data at older bridges, having higher probabilities of the occurrence of large flows, and bridges with known historical flows. On the basis of risk analysis and a review of historical flood records, it was concluded that flows equal to or exceeding 70 percent of the 100-year flow likely occurred at approximately 80 percent of the bridges in the investigation, with approximately 40 percent of the bridges having known historical floods that equaled or exceeded this flow value. The term "100-year flow" (or flood) is often used to describe a flood that has a 1 in 100 chance of being equaled or exceeded in any given year and also is referred to as the 1-percent annual exceedance probability flood (Holmes and Dinicola, 2010). Information on sites with known historical floods can be found in appendix 2. The South Carolina clear-water pier-scour depths were measured during low flows, and the flow conditions that produced the scour are not known. To estimate the hydraulic characteristics that may have produced the observed pier scour, numerical models were developed for each site by using the onedimensional step-backwater model, Water-Surface PROfile (WSPRO; Shearman, 1990; Arneson and Shearman, 1998). On the basis of the review of historic floods and the risk analysis, the 100-year flow was assumed to be an approximation of a common peak flow that may have occurred at all bridges, and this flow was used in the WSPRO model. The estimated hydraulic characteristics derived from the WSPRO model should be viewed as approximate rather than measured data. For additional information on the South Carolina clear-water pier-scour field data, refer to Benedict and Caldwell (2009).

\section{Clear-Water Pier-Scour Envelope Curve}

The pier-scour data collected by Benedict and Caldwell (2006) were used to develop the South Carolina clear-water pier-scour envelope curve (fig. 7) that reflects the upper bound of clear-water pier scour with respect to the nominal pier width (fig. 6) for the sampled bridges in South Carolina. Although the streams of the Coastal Plain and Piedmont have regional characteristics (table 1) that will likely influence scour in some measure, Benedict and Caldwell (2006) concluded that the data were insufficient to develop separate envelope curves for each region and, therefore, used a single envelope curve (fig. 7) encompassing data from both regions for assessing the upper bound of clear-water pier scour.

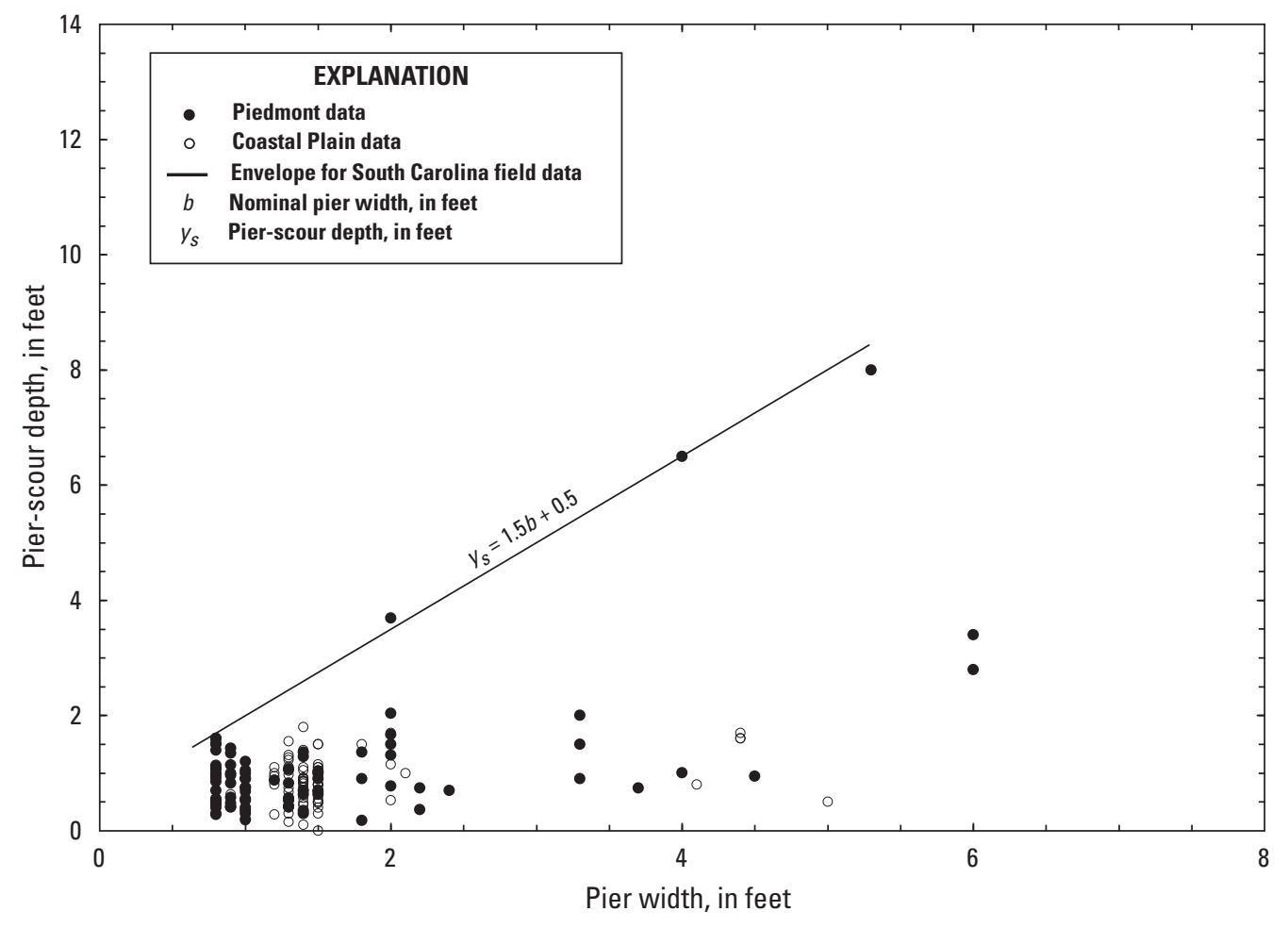

Figure 7. The South Carolina clear-water pier-scour envelope curve (from Benedict and Caldwell, 2006). 
The equation for the South Carolina clear-water pierscour envelope curve is as follows:

$$
y_{s}=1.5 b+0.5
$$

where

$$
\begin{gathered}
y_{s} \text { is the upper bound of potential pier-scour } \\
\text { depth, in feet, and } \\
b \quad \text { is the nominal pier width (fig. 6), in feet, } \\
\text { and is limited to a value of } 6 \text { or less. }
\end{gathered}
$$

This equation can be applied to round- and square-shaped piers with no skew to flow and to pile bents with moderate skews having spacings between piles of approximately 5 pile widths or greater. Benedict and Caldwell (2006) originally suggested that the "moderate skews" for pile bents be limited to approximately 20 degrees or less. However, to be consistent with the guidance for the South Carolina live-bed pier-scour envelope curve, as described later in the report, it is recommended that application of equation 2 be limited to pile bents with skews of 15 degrees or less having spacings between piles of approximately 5 pile widths or greater. When skews are thought to influence scour (such as for long, solid piers, pile bents with skews exceeding 15 degrees, or pile bents with relatively small spacing between piles), the skew-correction coefficient, as defined in HEC-18 (Arneson and others, 2012), can be applied to equation 2 as shown below:

$$
y_{s}=K_{2}(1.5 b+0.5)
$$

where $K_{2}$ is the HEC-18 (Arneson and others, 2012) correction coefficient for skew, and other variables are as previously defined. The following equation can be used to define $K_{2}$ :

$$
K_{2}=(\operatorname{cosine} \theta+L / b \operatorname{sine} \theta)^{0.65},
$$

where

$$
\begin{aligned}
& \theta \quad \text { is the skew angle of the major axis of } \\
& \text { the pier with respect to approaching flow } \\
& \text { (fig. 6), in degrees; } \\
& L \quad \text { is the pier length along the major axis } \\
& \text { (fig. 6), in feet; and other variables } \\
& \text { are as previously defined. }
\end{aligned}
$$

When the value of $L / b$ in equation 4 exceeds $12, L / b$ should be set to a value of 12. Reference should be made to Arneson and others (2012) for further guidance regarding the application and limitations of equation 4. Additional details regarding the development of the South Carolina clear-water pier scour envelope curve can be found in Benedict and Caldwell (2006), and reference to that report is encouraged for developing a more thorough understanding of that envelope curve. Application and limitations of equation 3 are described in more detail in the section of the current report, "Application and Limitations of the PSDb-2014 and South Carolina ClearWater and Live-Bed Pier-Scour Envelope Curves."

\section{Live-Bed Pier-Scour Envelope Curve}

Live-bed scour occurs at a bridge when upstream approach flows transport bed sediments into the area of scour (Arneson and others, 2012). In South Carolina, live-bed pier-scour typically occurs in the main channel of streams (see figure 4 for the definition of main channel) as illustrated by Benedict and Caldwell (2009; fig. 8). For the 100-year flow, figure 8 shows the ratio of the approach channel flow velocity to the sediment critical velocity for a sample of 78 bridges from the Coastal Plain and Piedmont regions of South Carolina and demonstrates how live-bed scour processes predominate the main channel. After a flood event, live-bed scour holes generally remain inundated and are partially or totally refilled with sediments. Therefore, to measure historical live-bed scour holes, the bathymetric surface of the hole, as well as the depth of sediment infill, must be measured. One method that has been used successfully to concurrently measure the bathymetry and sediment infill of historical live-bed scour holes is ground-penetrating radar (GPR) deployed by boat (Placzek and Haeni, 1995; Webb and others, 2000). The shallow (20 ft or less), freshwater, sandy streams of South Carolina provide a favorable environment for the application of GPR, and Benedict and Caldwell (2009) used this technique to measure live-bed pier and contraction scour at selected bridges in South Carolina. An example of a GPR measurement of pier scour is shown in figure 9, which displays the scour-hole bathymetric surface as well as the sediment infill.

\section{South Carolina Live-Bed Pier-Scour Field Data}

Benedict and Caldwell (2009) made 141 measurements of live-bed pier scour in the main channel of selected bridges in South Carolina, with 42 measurements in the Piedmont and 99 in the Coastal Plain (table 2). Bridge sites where live-bed pier-scour data were collected can be identified by referring to appendix 1 and figure 1. Measurements of pier-scour depths made in both provinces ranged from 1.7 to $16.9 \mathrm{ft}$ and were assumed to represent the maximum historical live-bed pierscour depth that has occurred at the bridge since construction. Nominal pier widths for these data ranged from 0.8 to $9 \mathrm{ft}$. Approximately 50 percent of the data were associated with pile bents having nominal pier widths of $1.6 \mathrm{ft}$ or less. A grab sample of sediment from the channel-bed surface was obtained in the upstream channel at each site and was analyzed to estimate the median grain size. Because sediment characteristics in the field setting can vary substantially in the vertical and horizontal direction, a grab sample taken at a point may not fully represent the sediment characteristics at a site.

Using an approach similar to the clear-water pier-scour investigation, Benedict and Caldwell (2009) collected live-bed pier-scour data at older bridges, having higher probabilities of the occurrence of large flows, and bridges with known historical flows to provide some assurance that 


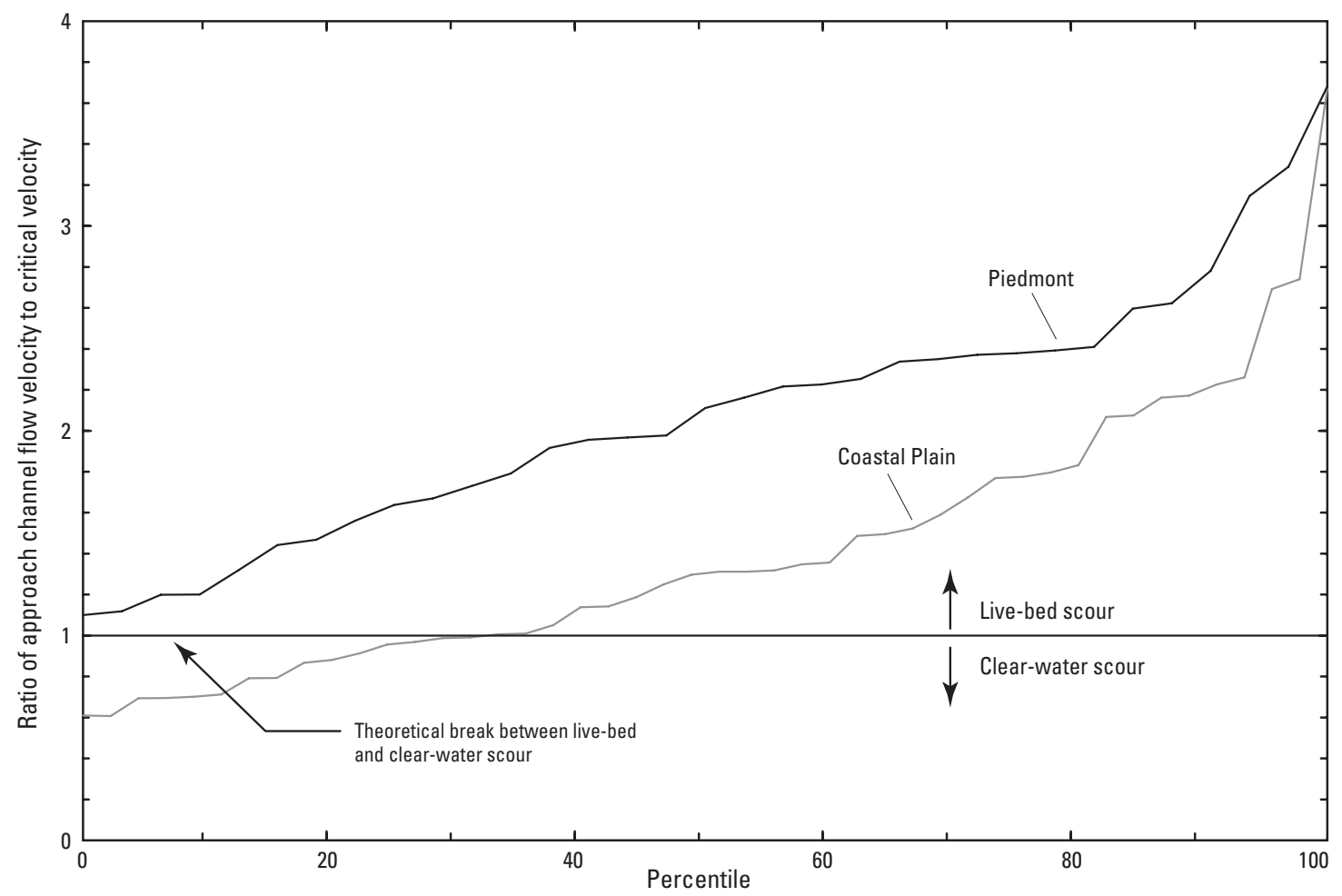

Figure 8. Distribution of the ratio of the average main-channel velocity to the critical velocity of the median grain size for selected bridges in the Coastal Plain and Piedmont of South Carolina (from Benedict and Caldwell, 2009).

Table 2. Range of selected characteristics of live-bed pier scour field data collected in the main channels of selected sites in South Carolina (Benedict and Caldwell, 2009).

$\left[\mathrm{mi}^{2}\right.$, square mile; ft/ft, foot per foot; ft/s, foot per second; ft, foot; mm, millimeter]

\begin{tabular}{|c|c|c|c|c|c|c|c|c|c|}
\hline $\begin{array}{l}\text { Range } \\
\text { value }\end{array}$ & $\begin{array}{c}\text { Drainage } \\
\text { area } \\
\left(\mathrm{mi}^{2}\right)\end{array}$ & $\begin{array}{c}\text { Channel } \\
\text { slope } \\
\text { (ft/ft) }\end{array}$ & $\begin{array}{l}\text { Nominal } \\
\text { pier width } \\
\text { (ft) }\end{array}$ & $\begin{array}{c}\text { Pier skew } \\
\text { (degree) }\end{array}$ & $\begin{array}{l}\text { aApproach } \\
\text { flow } \\
\text { velocity } \\
\text { (ft/s) }\end{array}$ & $\begin{array}{c}\text { aApproach } \\
\text { flow depth } \\
\text { (ft) }\end{array}$ & $\begin{array}{c}\text { Median } \\
\text { grain size } \\
(\mathrm{mm})\end{array}$ & $\begin{array}{l}\text { Measured } \\
\text { pier-scour } \\
\text { depth } \\
\text { (ft) }\end{array}$ & $\begin{array}{l}\text { Relative } \\
\text { scour depth } \\
\text { (ft) }\end{array}$ \\
\hline Minimum & 21.0 & 0.00015 & 0.8 & 0.0 & 1.7 & 6.8 & 0.5 & 2.1 & 0.6 \\
\hline Median & 201.0 & 0.0007 & 4.0 & 8.0 & 7.1 & 19.3 & 1.0 & 4.6 & 1.6 \\
\hline \multicolumn{10}{|c|}{ South Carolina Coastal Plain (99 measurements) } \\
\hline Minimum & 17.2 & 0.0001 & 0.9 & 0.0 & 0.8 & 2.8 & 0.24 & 1.7 & 0.5 \\
\hline Median & $1,030.0$ & 0.0003 & 1.5 & 0.0 & 4.2 & 15.6 & 0.64 & 3.8 & 1.8 \\
\hline Maximum & $9,360^{c}$ & 0.002 & 9.0 & 30.0 & 8.8 & 50.8 & 1.7 & 16.9 & 3.7 \\
\hline
\end{tabular}

${ }^{a}$ Values were estimated from a one-dimensional water-surface profile model.

${ }^{\mathrm{b}}$ Approximately 94 percent of the study sites in the Piedmont have drainage areas less than $760 \mathrm{mi}^{2}$.

'Approximately 80 percent of the study sites in the Coastal Plain have drainage areas less than 1,860 $\mathrm{mi}^{2}$. 


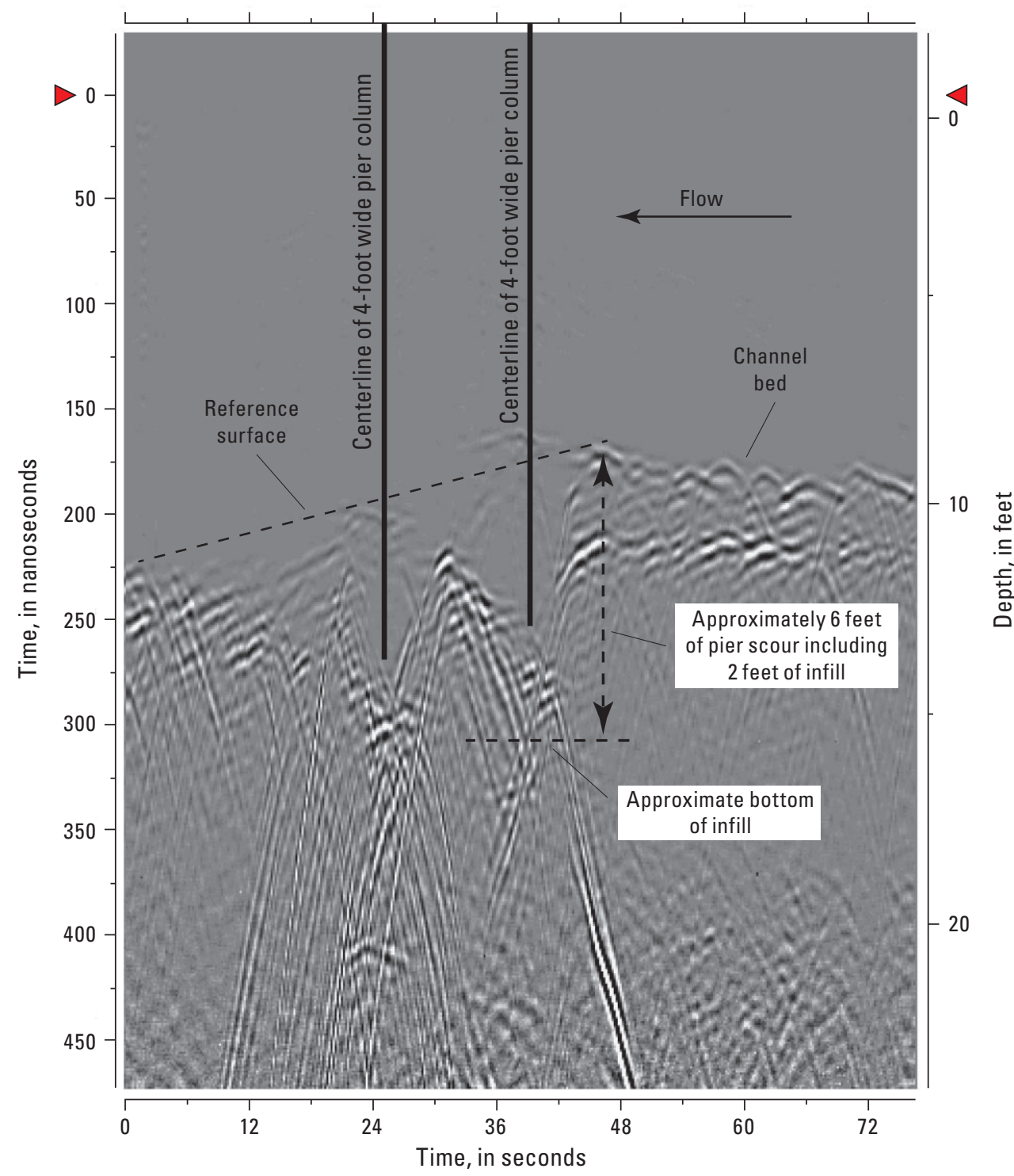

Figure 9. Example of groundpenetrating radar pier-scour profile at South Carolina Department of Transportation structure 364012100101 on S.C. Route 121 crossing the Saluda River in Newberry County, South Carolina.

measured historical scour reflected scour resulting from high flows. On the basis of risk analysis and a review of historical flood records, it was concluded that flows equal to or exceeding 70 percent of the 100-year flow likely occurred at approximately 96 percent of the bridges in the investigation, with approximately 62 percent of the bridges having known historical floods that equaled or exceeded this flow value. Information on sites with known historical floods can be found in appendix 2. As with the clear-water pier-scour data, the South Carolina live-bed pier-scour depths were measured during low flows; therefore, the WSPRO (Shearman, 1990; Arneson and Shearman, 1998) model was used to estimate the hydraulic characteristics that may have produced the observed pier scour. Many of the data-collection sites had gage data at or near the bridge (appendix 2) and historical peak flows based on the gage data were used in the WSPRO model. The 100-year flow was assumed to be an approximation of the peak flow at sites without gage data. The estimated hydraulic characteristics derived from the WSPRO model should be viewed as approximate rather than measured data. For additional information on the South Carolina live-bed pierscour field data, refer to Benedict and Caldwell (2009).

\section{Live-Bed Pier-Scour Envelope Curve}

The pier-scour data collected by Benedict and Caldwell (2009) were used to develop the South Carolina live-bed pierscour envelope curve (fig. 10) that reflects the upper bound of live-bed pier scour with respect to the nominal pier width (fig. 6) for the sampled bridges in South Carolina. Because of the differing regional characteristics in the Coastal Plain and Piedmont (table 2), the live-bed pier-scour data were initially 


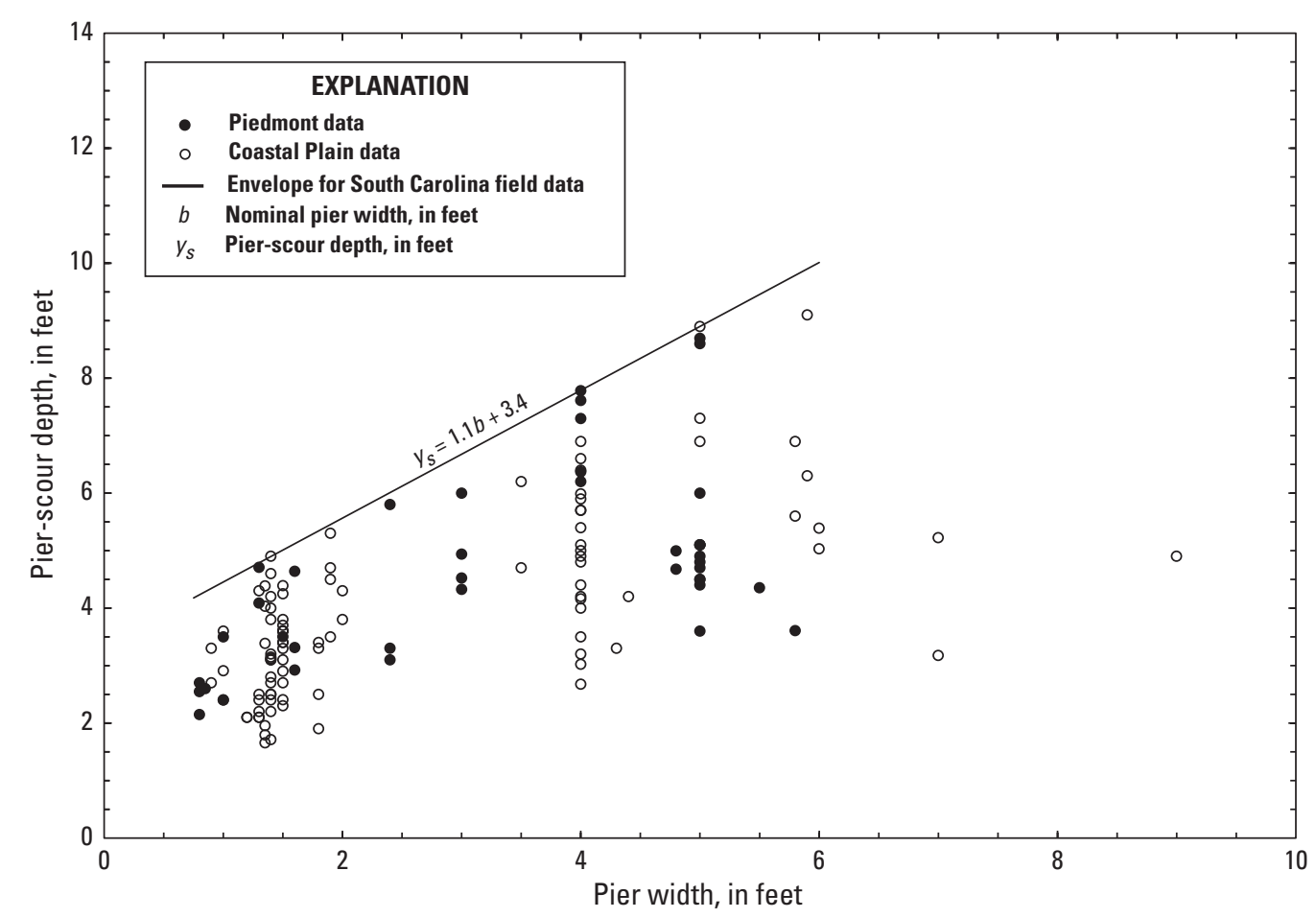

Figure 10. The South Carolina live-bed pier-scour envelope curve (from Benedict and Caldwell, 2009).

analyzed for regional trends. However, Benedict and Caldwell (2009) concluded that the regional distinctions were insignificant and combined the data for the analysis. The original equation for the South Carolina live-bed pier-scour envelope curve is as follows:

$$
y_{s}=1.11 b+3.34,
$$

where all variables are as previously defined. However, to be consistent with the significant figures of equation 2, equation 5 can be slightly modified by adjusting the equation constants to reflect one, rather than two, decimal place as represented in equation 6 :

$$
y_{s}=1.1 b+3.4
$$

where all variables are as previously defined. This minor modification produces negligible differences from the original equation over the range of applicable pier widths $(6 \mathrm{ft}$ or less) and is recommended for evaluating the upper bound of live-bed pier scour in South Carolina. Equation 6 can be applied to round- and square-shaped piers with no skew to flow and to pile bents with moderate skews (approximately 15 degrees or less) and spacings between piles of approximately 5 pile widths or greater. When skews are thought to influence scour (such as for long, solid piers, severely skewed pile bents, or pile bents with relatively small spacing between piles), the skew-correction coefficient, $K_{2}$, as defined in HEC-18 (Arneson and others, 2012; eq. 4), can be applied to equation 6 as follows:

$$
y_{s}=K_{2}(1.1 b+3.4) \text {, }
$$

where all variables are as previously defined. Reference should be made to Arneson and others (2012) for further guidance regarding the application and limitations of equation 4. Additional details regarding the development of the South Carolina live-bed pier-scour envelope curve can be found in Benedict and Caldwell (2009), and reference to that report is encouraged for developing a more thorough understanding of that envelope curve. Application and limitations of equations 6 and 7 are described in more detail in the section of the current report, "Application and Limitations of the PSDb-2014 and South Carolina Clear-Water and Live-Bed Pier-Scour Envelope Curves." 


\section{Comparison of the South Carolina Pier- Scour Envelope Curves With Other Data}

Benedict and Caldwell (2006, 2009) made some limited comparisons of the South Carolina pier-scour data with data from other sources, including selected laboratory and field data. The comparison of the South Carolina field data with laboratory data is shown in figure 11. The laboratory measurements (no skewed piers) are those used to develop the original HEC-18 pier-scour equation (Richardson and others, 1991; laboratory data provided by J.S. Jones, Federal Highway Administration, written commun., October 2003). The dimensionless variables shown in the figure are based on a simplified form of the HEC-18 equation as represented by the trend line through the laboratory data. The field measurements in figure 11 represent selected data from South Carolina having no or minimal influence from pier skew, including clear-water (fig. 11A) and live-bed (fig. 11B) pier-scour data. The slope of the trend lines through the South Carolina field data (fig. 11) are similar to that of the laboratory data, indicating that the trends of the field data are similar to those associated with the laboratory. In the case of the clear-water pier-scour field measurements (fig. 11A), most of the data plot below the laboratory data thus causing the field data trend line to be below the laboratory trend line. The smaller relative scour depths associated with the clear-water field data are likely caused by a combination of factors including (1) cohesive and (or) non-uniform flood plain sediments, (2) flood plain flow velocities that are substantially below the sediment critical velocity (fig. 3), and (3) short flood-flow durations, all of which diminish the potential for scour. It is notable that some of the clear-water field data (fig. 11A) conform to the upper bound of the laboratory data, indicating that the South Carolina clear-water pier scour measurements are likely capturing the upper bound of scour. The trend line for the live-bed pier-scour field measurements (fig. 11B) plots close to the laboratory trend line, and the field data have an approximate uniform scatter about the laboratory trend line. These patterns indicate that the live-bed field data have similar characteristics to that of the laboratory data, confirming that the field data are reasonable. Some of the live-bed pier-scour measurements exceed the laboratory data, and Benedict and Caldwell (2009) note that this is likely caused by the larger measurement uncertainty associated with defining the scourhole infill by the interpretation of GPR data (fig. 9).

Part of the analysis by Benedict and Caldwell (2009) included a comparison of the South Carolina live-bed pierscour envelope curve with the upper bound of pier scour on the basis of 92 measurements selected from the National Bridge Scour Database (NBSD; U.S. Geological Survey, 2001) having similar sediment sizes to the South Carolina data (fig. 12). With the exception of three data points, all of the data fall within, or near to, the South Carolina live-bed pier-scour envelope curve, providing some support for that curve. However, the data points that define the upper bound of the data are sparse (two data points; fig. 12), making it difficult to form strong conclusions regarding the validity of the envelope curve and its comparison with the South Carolina pier-scour envelope curves. The data patterns in figure 12 indicate the need for further evaluation of the South Carolina live-bed pier-scour envelope curves with a larger set of data, which is one of the objectives of the current (2016) investigation. To facilitate such an evaluation, Benedict and Caldwell (2014) conducted a literature review to identify potential sources of pier-scour data that could be compared with the South Carolina pier-scour envelope curves. This effort led to the development of the 2014 USGS Pier Scour Database (PSDb-2014) that includes 2,427 field and laboratory measurements of both clear-water and live-bed pier scour (Benedict and Caldwell, 2014). Selected data from this extensive database were used to evaluate the upper bound of pier-scour depth and were compared with the South Carolina clear-water and live-bed pier-scour envelope curves. The following report sections provide a description of (1) the PSDb-2014 database, (2) the development of the envelope curve defined with selected data from the PSDb-2014 database, and (3) the comparison of the PSDb-2014 envelope curve with the South Carolina pier-scour envelope curves.

\section{The PSDb-2014 Database}

The PSDb-2014 (Benedict and Caldwell, 2014) consists of 569 laboratory and 1,858 field measurements of clear-water and live-bed pier scour compiled from selected publications. The laboratory data (table 3 ) are measurements taken from 17 previous investigations and originally compiled by Sheppard and others (2011). The field data (table 4) were compiled from 32 previous publications and include measurements made in 23 states within the United States and six other countries. The field data have a wide range of stream gradients, drainage areas, sediment sizes, flow depths, flow velocities, and pier sizes, providing a large and diverse database for assessing the upper bound of pier scour. Several subsets of data within the PSDb-2014 are pertinent to the evaluation of the upper bound of pier scour and are described below. Additional information regarding the PSDb-2014 (Benedict and Caldwell, 2014) is available at http://pubs.usgs.gov/ds/0845/.

\section{South Carolina Clear-Water and Live-Bed Pier-Scour Field Data}

Included in the PSDb-2014 are the clear-water and live-bed pier-scour measurements made as part of the South Carolina investigations (Benedict and Caldwell, 2006, 2009; 335 measurements; tables 1 and 2). (Note: The PSDb-2014 includes 15 measurements purposefully excluded from the original analysis by Benedict and Caldwell $(2006,2009)$; therefore, tables 1 and 2 contain only 320 measurements.) Data from the PSDb-2014 were used to evaluate the trends of the South Carolina data; therefore, the South Carolina data were excluded from the analysis of the upper bound of pier scour on the basis of the PSDb-2014 data. 


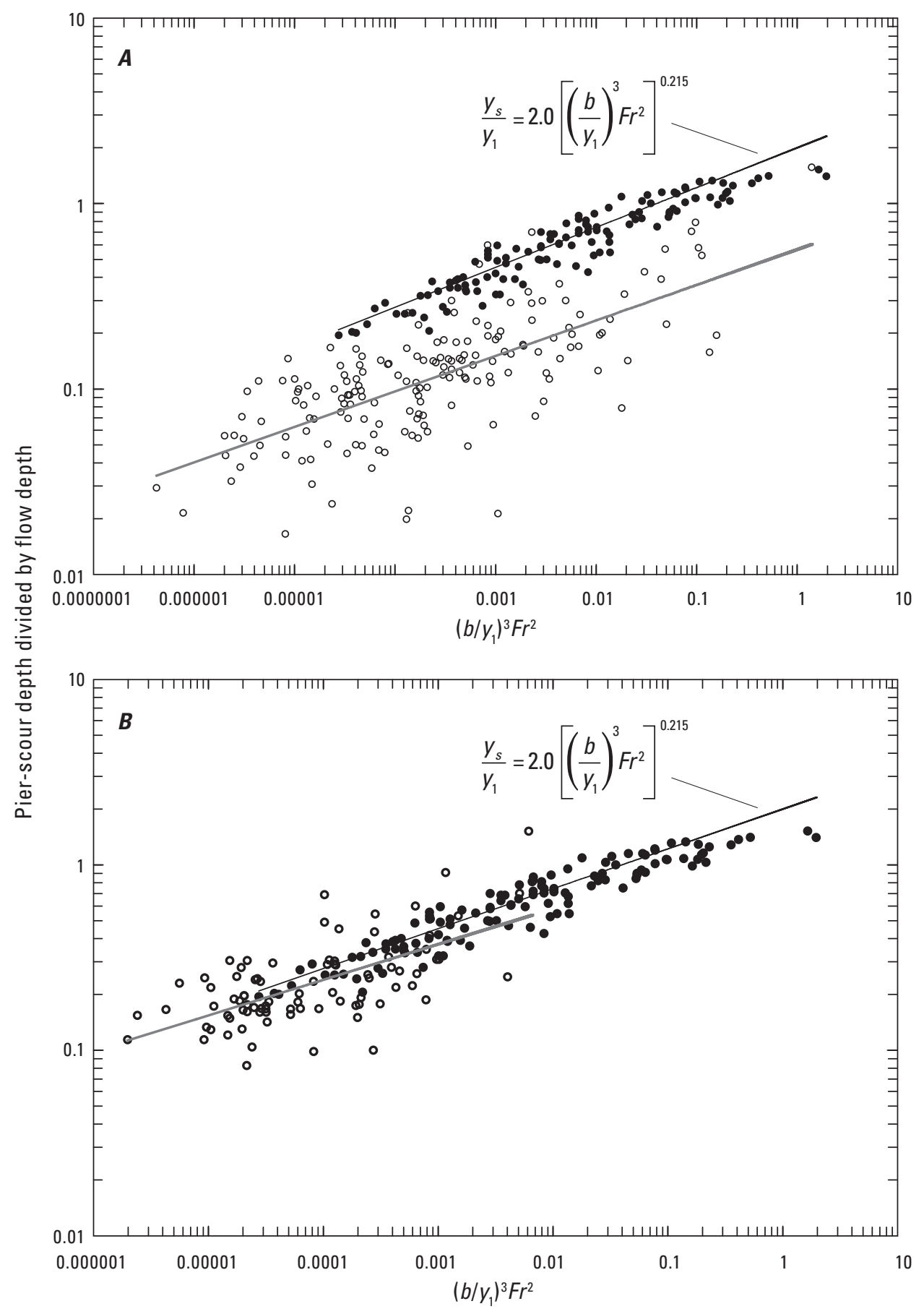

EXPLANATION

— Line for original HEC-18 equation

Power trend line for South Carolina field data

$b$ Pier width

Laboratory data for original HEC-18 equation (Richardson and others, 1991)

$y_{s}$ Pier-scour depth

- South Carolina clear-water field data
- South Carolina live-bed field data

$Y_{1}$ Approach flow depth

Fr Approach Froude number

Figure 11. Relation of relative scour to the dimensionless variable, $\left(b / y_{1}\right)^{3} \mathrm{Fr}^{2}$, for laboratory data used to develop the original HEC-18 pier-scour equation (Richardson and others, 1991) and $(A)$ clear-water and $(B)$ live-bed pier-scour data from selected sites in South Carolina (from Benedict and Caldwell, 2006 and 2009, respectively) 


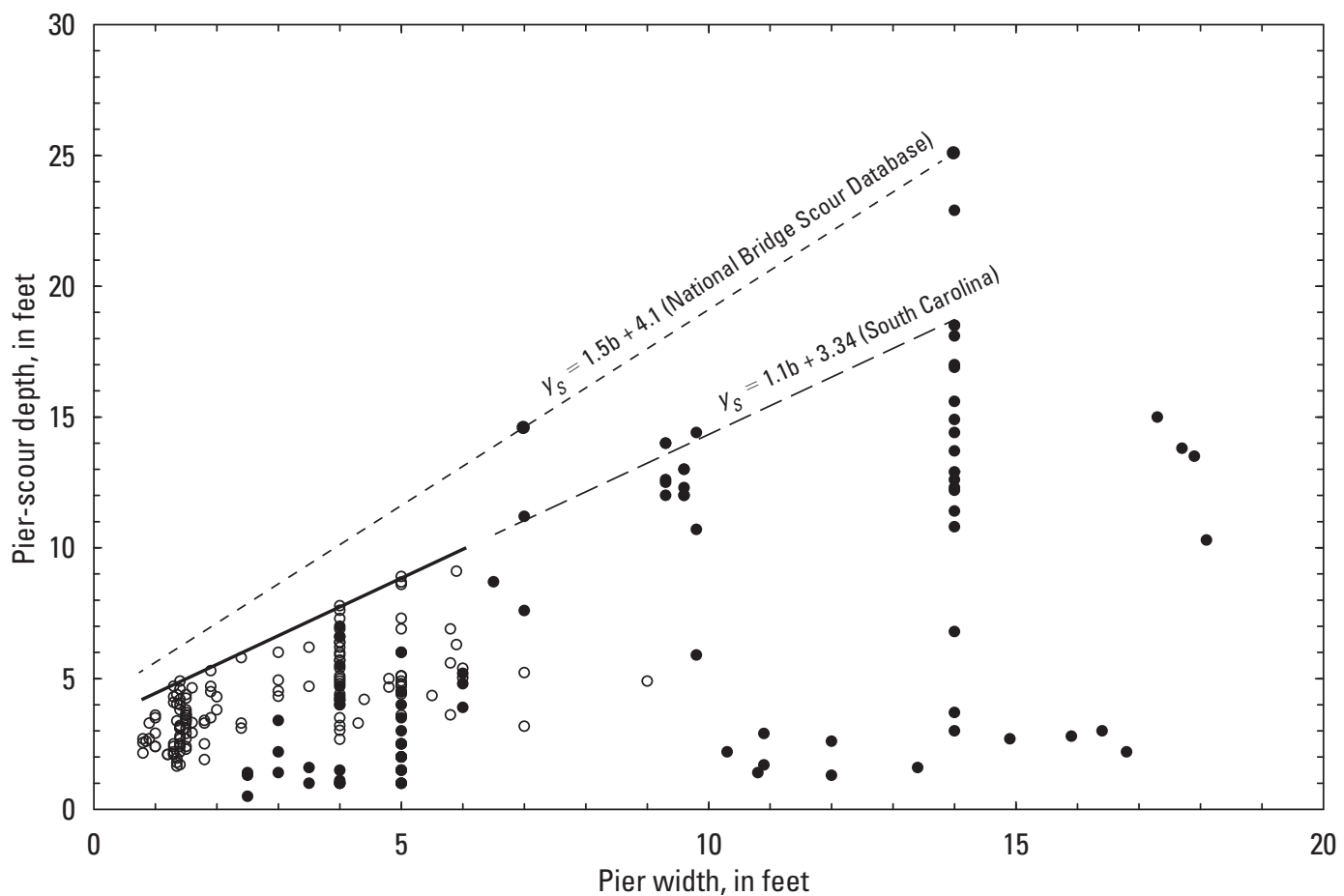

EXPLANATION

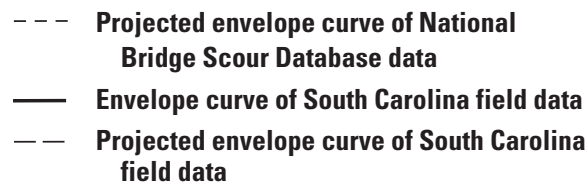

- South Carolina live-bed field data

- National Bridge Scour Database data

$y_{S}$ Scour depth, in feet

$b$ Pier width, in feet ( $b \leq 6$ feet for the South Carolina envelope curve)

Figure 12. Comparison of the South Carolina live-bed pier-scour envelope curve with the envelope curve developed from selected field data from the National Bridge Scour Database (from Benedict and Caldwell, 2009).

Table 3. Range of selected characteristics for the laboratory measurements of pier scour compiled in the PSDb-2014 (Benedict and Caldwell, 2014).

[ft, foot; ft/s, foot per second; mm, millimeter]

\begin{tabular}{lcccccc}
\hline $\begin{array}{c}\text { Range } \\
\text { value }\end{array}$ & $\begin{array}{c}\text { Nominal } \\
\text { pier width } \\
\text { (ft) }\end{array}$ & $\begin{array}{c}\text { Approach } \\
\text { flow velocity } \\
\text { (ft/s) }\end{array}$ & $\begin{array}{c}\text { Approach } \\
\text { flow depth } \\
\text { (ft) }\end{array}$ & $\begin{array}{c}\text { Median } \\
\text { grain size } \\
(\mathbf{m m})\end{array}$ & $\begin{array}{c}\text { Measured } \\
\text { pier-scour } \\
\text { depth } \\
\text { (ft) }\end{array}$ & $\begin{array}{c}\text { Relative } \\
\text { scour depth } \\
\text { (ft) }\end{array}$ \\
\hline Minimum & 0.1 & 0.5 & 0.1 & 0.2 & 0.0 & 0.1 \\
Median & 0.2 & 1.4 & 0.6 & 0.8 & 0.3 & 1.5 \\
Maximum & 3.0 & 7.1 & 6.2 & 7.8 & 4.6 & 3.1 \\
\hline & Screened laboratory data in the PSDb-2014 (441 measurements) & 0.0 & 0.1 \\
\hline Minimum & 0.1 & 0.5 & 0.1 & 0.2 & 0.3 & 1.5 \\
Median & 0.2 & 1.6 & 0.6 & 0.8 & 4.6 & 3.1 \\
Maximum & 3.0 & 7.1 & 6.2 & 7.8 & & \\
\hline
\end{tabular}


Table 4. Range of selected characteristics for the field measurements of pier scour compiled in the PSDb-2014 (Benedict and Caldwell, 2014).

$\left[\mathrm{mi}^{2}\right.$, square mile; ft/ft, foot per foot; ft/s, foot per second; ft, foot; $\mathrm{mm}$, millimeter]

\begin{tabular}{|c|c|c|c|c|c|c|c|c|c|c|}
\hline Range value & $\begin{array}{c}\text { Drainage } \\
\text { area } \\
\left(\mathrm{mi}^{2}\right)\end{array}$ & $\begin{array}{c}\text { Channel } \\
\text { slope } \\
(\mathrm{ft} / \mathrm{ft})\end{array}$ & $\begin{array}{l}\text { Nominal } \\
\text { pier width } \\
\text { (ft) }\end{array}$ & $\begin{array}{l}\text { Pier width } \\
\text { normal } \\
\text { to flow } \\
\text { (ft) }\end{array}$ & $\begin{array}{c}\text { Pier skew } \\
\text { (degree) }\end{array}$ & $\begin{array}{l}\text { Approach } \\
\text { flow } \\
\text { velocity } \\
\text { (ft/s) }\end{array}$ & $\begin{array}{l}\text { Approach } \\
\text { flow } \\
\text { depth } \\
\text { (ft) }\end{array}$ & $\begin{array}{l}\text { Median } \\
\text { grain size } \\
(\mathrm{mm})\end{array}$ & $\begin{array}{l}\text { Measured } \\
\text { pier-scour } \\
\text { depth } \\
\text { (ft) }\end{array}$ & $\begin{array}{c}\text { Relative } \\
\text { scour } \\
\text { depth } \\
\text { (ft) }\end{array}$ \\
\hline \multicolumn{11}{|c|}{ All field data in the PSDb-2014 (1,858 measurements) } \\
\hline Minimum & 3.1 & 0.00007 & 0.8 & 0.7 & 0 & 0 & 0 & 0.001 & 0.0 & 0.0 \\
\hline Median & 1,081 & 0.0005 & 3 & 5 & 0 & 4.2 & 9.8 & 0.94 & 2.3 & 0.5 \\
\hline Missing data & 556 & 775 & 336 & 0 & 341 & 34 & 28 & 72 & 0 & 0 \\
\hline \multicolumn{11}{|c|}{ Screened field data in the PSDb-2014 (727 measurements) } \\
\hline Minimum & 64 & 0.00008 & 0.95 & 0.7 & 0 & 0.3 & 0.4 & 0.1 & 0.0 & 0.0 \\
\hline Median & 2,400 & 0.00060 & 3.6 & 7.7 & 0 & 4.1 & 7.7 & 1.3 & 2.8 & 0.5 \\
\hline Minimum & 3 & 0.0001 & 1 & 1 & 0 & 0.0 & 0.0 & 0.01 & 0.0 & 0 \\
\hline Median & 1,350 & 0.00019 & 3 & 4 & 0 & 4.1 & 11.8 & 0.74 & 2.0 & 0.4 \\
\hline Maximum & 697,000 & 0.005 & 64 & 94 & 66 & 12.8 & 64.0 & 108 & 34.1 & 4.2 \\
\hline Missing data & 86 & 260 & 0 & 0 & 0 & 6 & 0 & 13 & 0.0 & 0 \\
\hline
\end{tabular}

a Sheppard and others (2011) published 791 measurements of screened field data; however, selected data were removed, reducing the number of measurements of screened field data to 727 .

\section{Screened Laboratory and Field Data}

Sheppard and others (2011) screened selected laboratory and field data to identify pier-scour measurements considered to represent equilibrium scour depths, and these data, consisting of 441 laboratory and 727 field measurements (tables 3 and 4, respectively), were included in the PSDb-2014. The screened laboratory and field data provide a large and high-quality set of equilibrium pier-scour depths that can be used to investigate the upper bound of pier scour to assist in evaluating the South Carolina pier-scour envelope curves.

\section{Verification Data}

The remaining unscreened field measurements in the PSDb-2014, excluding the South Carolina data, provide a good source of data (796 measurements) to verify the upper bound of pier scour defined by the screened data. The unscreened field data represent various types of scour measurements, including post-flood and during-flood measurements. Pier-scour measurements obtained during a flood are considered to have less measurement uncertainty than post-flood measurements (Benedict and Caldwell, 2014).
Therefore, the 569 unscreened field measurements in the PSDb-2014 made during flood conditions (table 4) were used as the dataset to verify the upper bound of pier scour defined with the screened data.

\section{Skewed Piers}

The PSDb-2014 includes piers aligned with the approaching flow (569 laboratory measurements; 1,033 field measurements) as well as skewed piers (0 laboratory measurements; 536 field measurements; unknown at 289 field measurements), and when evaluating the upper bound of pier scour, special consideration must be given to the skewed piers. Skewed piers tend to produce larger scour depths; therefore, in an upper-bound analysis, the scour depths should be adjusted to reflect scour depths comparable to piers aligned with the flow. This adjustment can be accomplished in several ways, including (1) normalizing the scour measurement by dividing it by the skew correction coefficient, $K_{2}$, as determined from equation 4, or (2) using the effective pier width (fig. 6) rather than the nominal pier width to represent a comparable unskewed pier that would likely have produced the scour of the skewed pier. The effective pier width can be determined from the following equation: 


$$
b_{e}=b \operatorname{cosin} e \theta+L \sin e \theta,
$$

where $b$ is the effective pier width perpendicular to flow, in feet, and other variables are as previously defined in figure 6 .

When a pier is aligned with the flow (no skew), the effective pier width is considered identical to the nominal pier width. Although there are differences in the various methods for adjusting for skew, Sheppard and others (2011) noted that when incorporated into the scour-prediction equations, the methods yielded similar results. Benedict and Caldwell (2015) evaluated the upper bound of pier scour using the nominal pier width with selected data from the PSDb-2014 database. (Note: Some of the measurements in the PSDb-2014 database provide only the effective pier width, requiring some of the field data to be excluded when limiting the analysis to nominal pier widths.) Similarly, an evaluation of the upper bound of pier scour using the effective pier width for all of the PSDb-2014 data was made by Benedict and Caldwell (2016). Although the plotting positions for skewed piers differ with these methods, the analysis yielded identical upper-bound envelope curves, confirming in some measure the observation of Sheppard and others (2011) that the two methods for adjusting for pier skew are similar. For additional details regarding these differing approaches for evaluating the upper bound of pier scour with the PSDb-2014 data, reference can be made to Benedict and Caldwell $(2015,2016)$.

\section{The PSDb-2014 Pier-Scour Envelope Curve}

The South Carolina clear-water and live-bed pier-scour envelope curves (figs. 7,10$)$ were developed using the nominal pier width; therefore, the analysis of the upper bound of pier scour for the PSDb-2014 presented in this report used that approach. In the case of skewed piers, the measured scour depth was adjusted by dividing by $K_{2}$, as described in the preceding report section "Skewed Piers." The exception to this approach was for 317 measurements of the screened field data where the effective pier width was used in the analysis because the nominal pier width was not published in the original source. As noted previously, the analysis by Benedict and Caldwell $(2015,2016)$ indicates that using the nominal or effective pier width yields the same envelope curve for the PSDb-2014 data, which demonstrates that using the effective pier width for these 317 measurements rather than the nominal pier width, will not bias the analysis of the upper bound of pier scour. The upper bound analysis of the PSDb-2014 presented in this report uses the same general approach presented in Benedict and Caldwell $(2015,2016)$ and yields the same envelope curve. The primary difference in these analyses is the differing datasets selected from the PSDb-2014. The evaluation of the upper bound of pier scour using the PSDb-2014 data was conducted in a stepwise process using the high-quality, screened laboratory data (table 3) to initially define the envelope curve, extending that curve with the screened field data (table 4), and then verifying the curve with the unscreened verification field data (table 4). The results of these steps are presented below.

\section{Envelope Curve for the PSDb-2014 Screened Laboratory Pier-Scour Data}

The relation of pier-scour depth to nominal pier width, using the 441 screened laboratory measurements, is shown in figure 13. A log-log scale is used to better display the upper bound of the data. With only two exceptions, the upper bound of the data displays a well-defined relation. The two data points that slightly exceed the line are from the investigation by Jain and Fischer (1979) and have high Froude numbers (1.2 and 1.5). Jain and Fischer (1979) note that the flow conditions associated with these two measurements were very turbulent and unsteady, making the measurements questionable and justifying their exclusion in defining the upper bound of the data. The envelope curve in figure 13 can be represented by the following equation:

$$
y_{s}=2.1 b^{0.9},
$$

where all variables are as previously defined. If the laboratory data plotted in figure 13 are capturing the upper bound of pier-scour depth that is anticipated in the field, it would be reasonable to expect that the upper bound of the field data would conform to the extension of the envelope curve shown in figure 13.

\section{Extending the Envelope Curve With the PSDb-2014 Screened Field Data}

Figure 14 shows the relation of scour depth to pier width for the 727 screened field measurements, as previously described, using the same format as figure 13, with an extension of the envelope curve derived from the laboratory data. The nominal pier width was used to plot the screened field data, with the exception of the 317 measurements where the effective pier width was used because of data limitations as previously described. The data associated with the nominal and effective piers widths for the screened field data are identified in figure 14. Although there is more scatter in the upper bound of the screened field data than in the upper bound of the laboratory data, the screened field data conform well to the envelope curve of the laboratory data, indicating that the laboratory envelope curve provides a reasonable definition of the upper bound of pier scour in the field as well as in the laboratory. There are four field measurements that exceed the envelope curve with exceedance values ranging from 0.3 and $2.5 \mathrm{ft}$ and an average value of $1.1 \mathrm{ft}$. The complexities of the field, combined with the harsh measuring environment, make it difficult to measure pier scour to the same degree of accuracy as in the laboratory; therefore, it is expected that some field measurements may exceed the upper bound of the laboratory data. Because the exceedance values are small, no adjustment was made to the envelope curve to account for these four data points. 


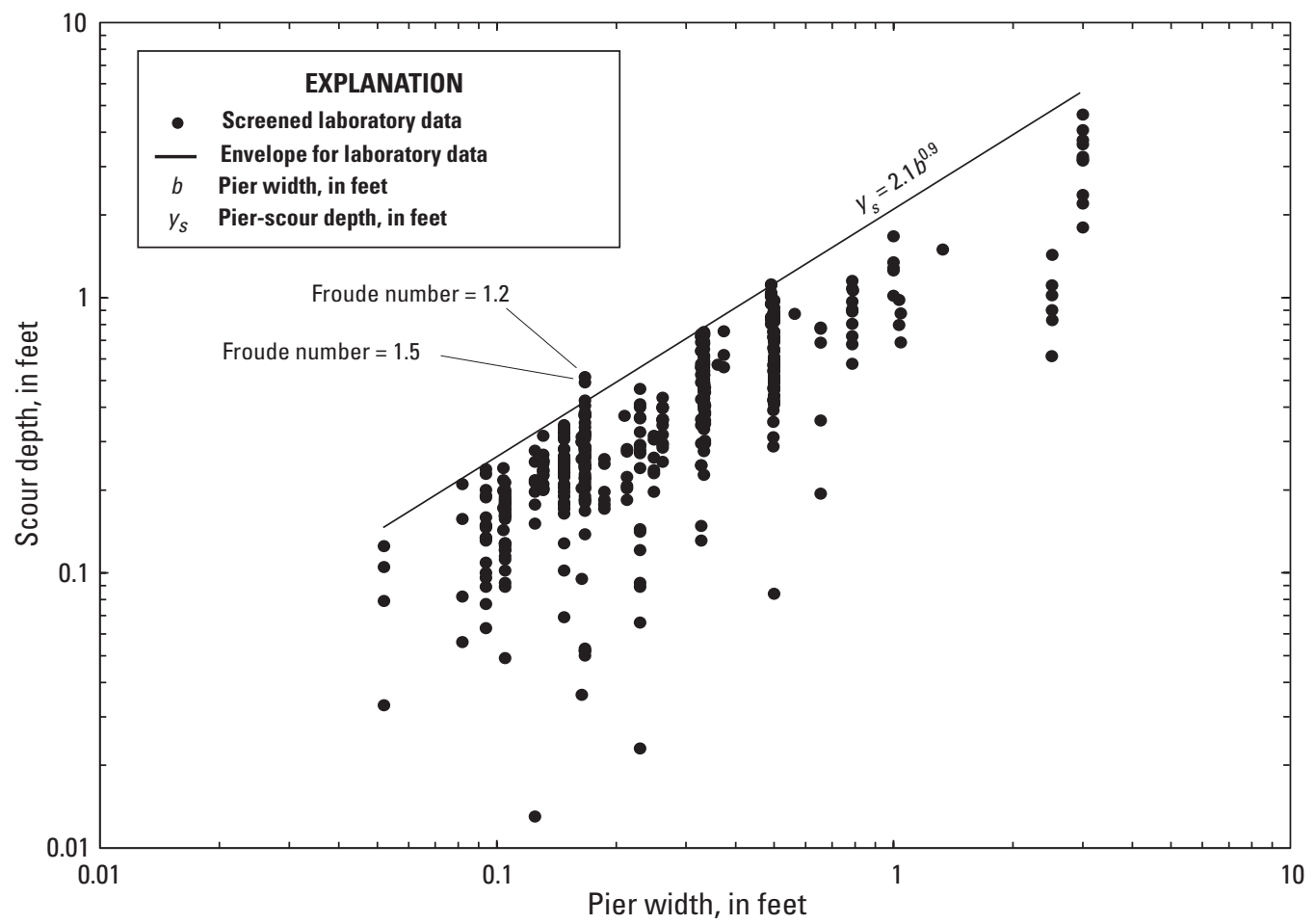

Figure 13. Relation of scour depth to pier width for the screened laboratory data from the PSDb-2014 database.

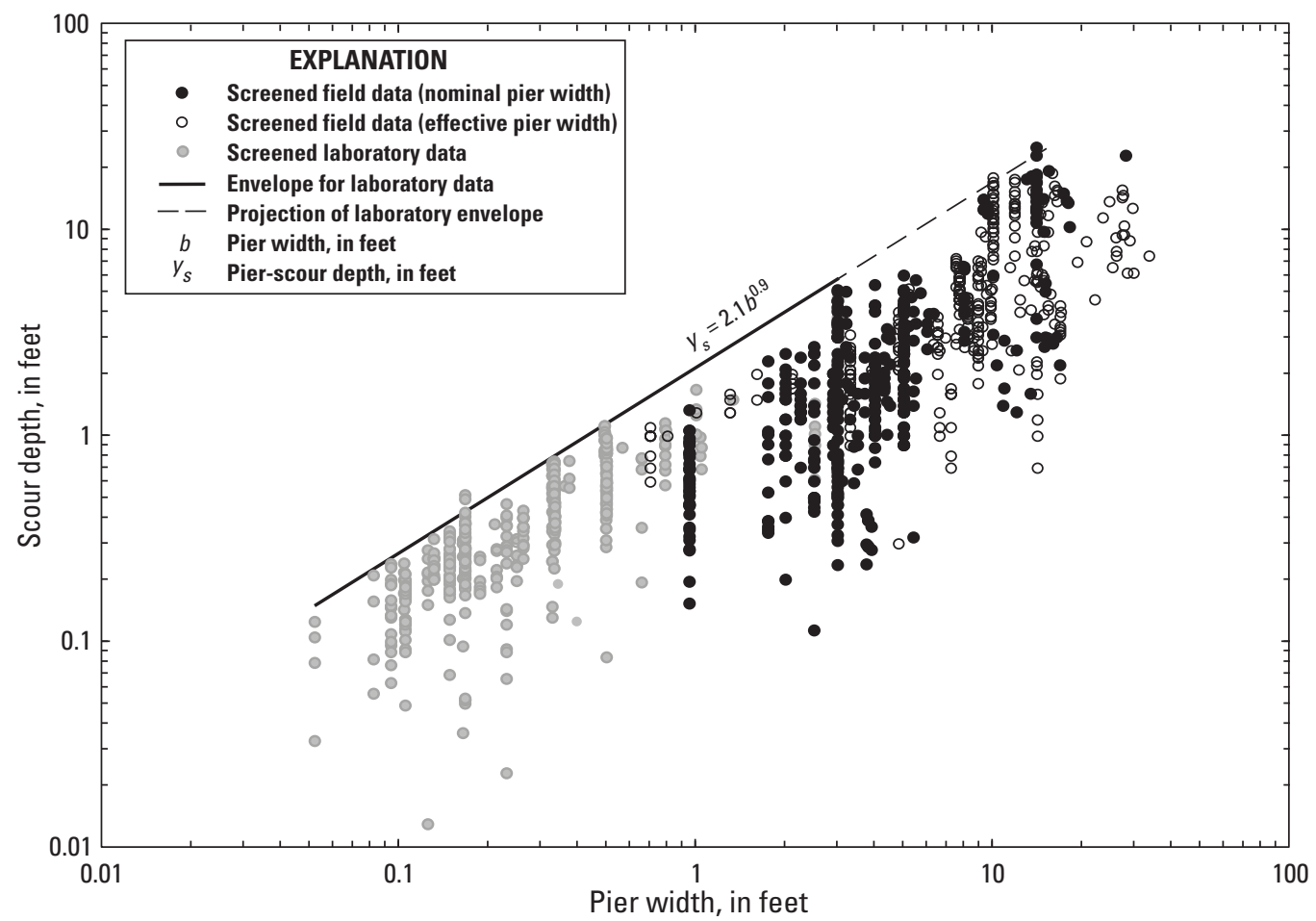

Figure 14. Relation of scour depth to pier width for the screened laboratory and field data from the PSDb-2014 database. 


\section{Verifying the Envelope Curve With the PSDb-2014 Unscreened Field Data}

The 569 unscreened verification field measurements made during high flows, as previously described, are plotted in figure 15 along with the screened laboratory and field data. Twelve of the verification measurements exceeded the envelope curve, with exceedance values ranging from 0.2 to $3.3 \mathrm{ft}$ and a median exceedance of $1.1 \mathrm{ft}$. As noted above, measurement error associated with field data possibly accounts for this exceedance, and because the exceedance is small, no adjustment was made to the envelope curve. The verification data provide further confirmation that the envelope curve shown in figures 14 and 15 is a reasonable upper bound for pier scour.

\section{Review of Field Data That Exceed the Envelope Curve}

Figure 16 shows the same data that are in figure 15 but using an arithmetic rather than logarithmic scale to provide perspective on the data relations and envelope curve on the differing scales. The scale of the horizontal axis in figure 16 has been truncated to a value of $30 \mathrm{ft}$ for clarity. Additionally, a 2.5 -ft offset from the envelope curve defined by equation 9 is shown in figure 16 to provide perspective on the data that exceed the curve. The data exceeding the envelope curve were reviewed to evaluate if there were site conditions that may have contributed to the exceedance, and table 5 lists the findings of that review. Although four of the measurements have insufficient information to evaluate the possible cause of the exceedance, three of those measurements have small exceedance values less than $1.5 \mathrm{ft}$. Seven measurements have exceedances that fall within the published accuracy of the measurement, and the remaining five measurements have some plausible explanation for their exceedance. The large number of measurements (441 laboratory and 1,296 field measurements) used to develop the PSDb-2014 pier-scour envelope curve, in conjunction with the information in table 5, indicates that it is a reasonable approximation of the upper bound of pier scour for both the laboratory and field. The PSDb-2014 pier-scour envelope curve is defined most clearly for nominal pier widths of approximately $15 \mathrm{ft}$ or less.

The equation for the PSDb-2014 pier-scour envelope curve is expressed in equation 9 where nominal pier widths are limited to $15 \mathrm{ft}$ or less. The data used to develop the PSDb-2014 envelope curve include variously shaped piers and pile bents having live-bed and clear-water scour conditions; therefore, it is assumed that the PSDb-2014 envelope curve is applicable to piers with those conditions. When the skew of a pier to flow is thought to influence scour, the skew-correction coefficient, as defined in HEC-18 (Arneson and others, 2012; eq. 4), can be applied to equation 9 as follows:

$$
y_{s}=K_{2}\left(2.1 b^{0.9}\right)
$$

where all variables are as previously defined. Reference should be made to Arneson and others (2012) for further guidance regarding the application and limitations of equation 4.

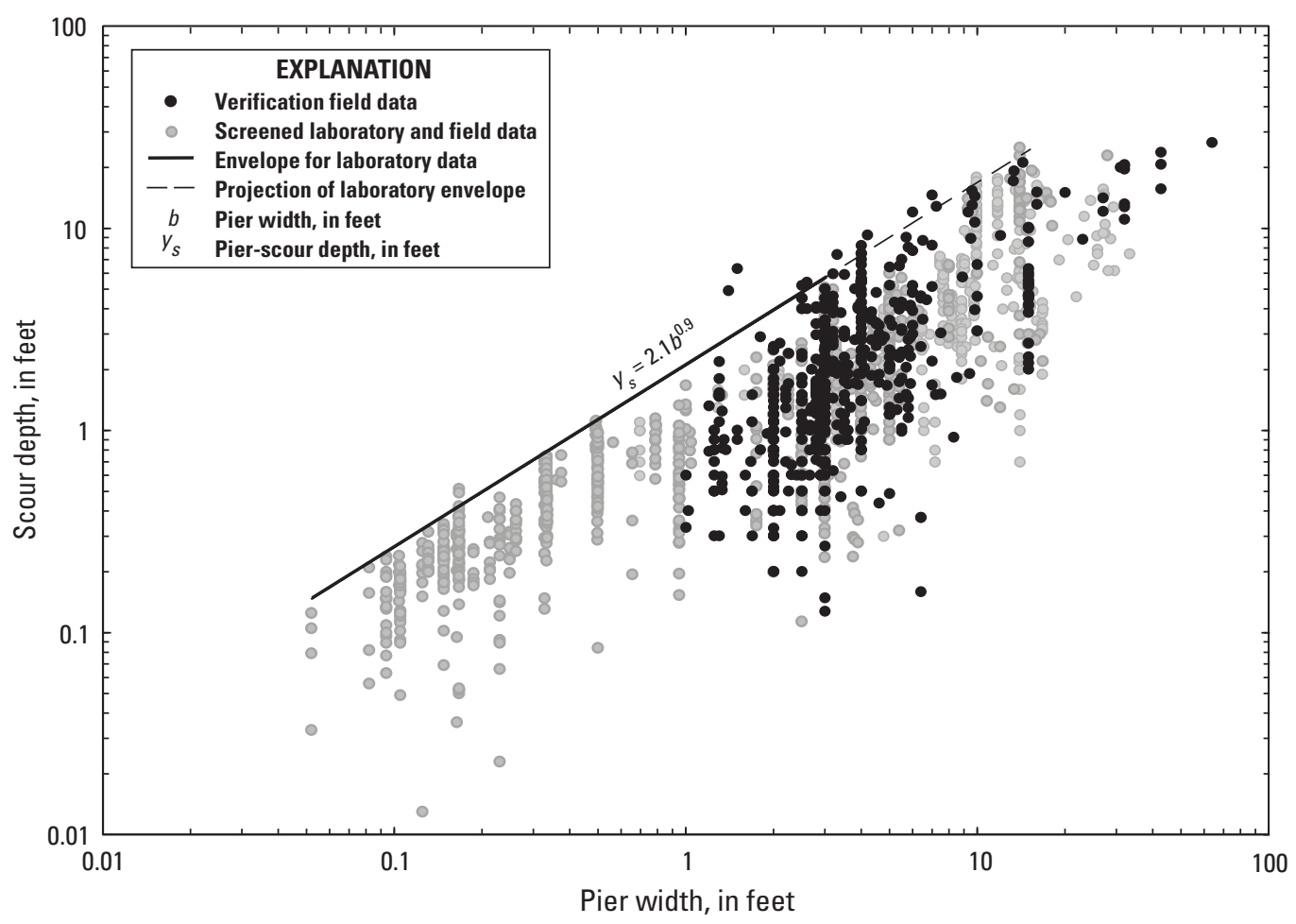

Figure 15. Relation of scour depth to pier width for the screened laboratory and field data and verification data from the PSDb-2014 database. 
Table 5. Review of selected data points exceeding the PSDb-2014 pier-scour envelope curve.

[ID, identification; ft, foot; ft/s, foot per second; —, missing data]

\begin{tabular}{|c|c|c|c|c|c|c|c|c|c|}
\hline $\begin{array}{l}\text { ID number } \\
\text { for data } \\
\text { points in } \\
\text { figure } 16\end{array}$ & $\begin{array}{c}\text { Exceedance } \\
\text { of envelope } \\
\text { curve } \\
\text { (ft) }\end{array}$ & $\begin{array}{c}\text { Pier } \\
\text { width } \\
\text { (ft) }\end{array}$ & $\begin{array}{c}\text { Pier } \\
\text { length } \\
\text { (ft) }\end{array}$ & $\begin{array}{c}\text { Skew } \\
\text { angle } \\
\text { (degree) }\end{array}$ & $\begin{array}{c}\text { Flow } \\
\text { velocity } \\
\text { (ft/s) }\end{array}$ & $\begin{array}{l}\text { Flow } \\
\text { depth } \\
\text { (ft) }\end{array}$ & $\begin{array}{l}\text { Measured } \\
\text { scour depth } \\
\text { adjusted } \\
\text { for skew } \\
\text { (ft) }\end{array}$ & $\begin{array}{l}\text { Published } \\
\text { measurement } \\
\text { accuracy } \\
\text { (ft) }\end{array}$ & Comment \\
\hline 1 & 2.5 & 14 & 54 & 0 & 9.5 & 32.1 & 25.1 & 1 & $\begin{array}{l}\text { A small error in the measurement } \\
\text { of the skew angle at this long, } \\
\text { solid pier could account for the } \\
\text { exceedance. For example, a skew } \\
\text { angle of } 2 \text { degrees brings the } \\
\text { exceedance of the scour depth } \\
\text { adjusted for skew within the pub- } \\
\text { lished accuracy of the measure- } \\
\text { ment. A skew angle of } 3 \text { degrees } \\
\text { brings the measurement adjusted } \\
\text { for skew below the PSDb-2014 } \\
\text { envelope curve. }\end{array}$ \\
\hline
\end{tabular}

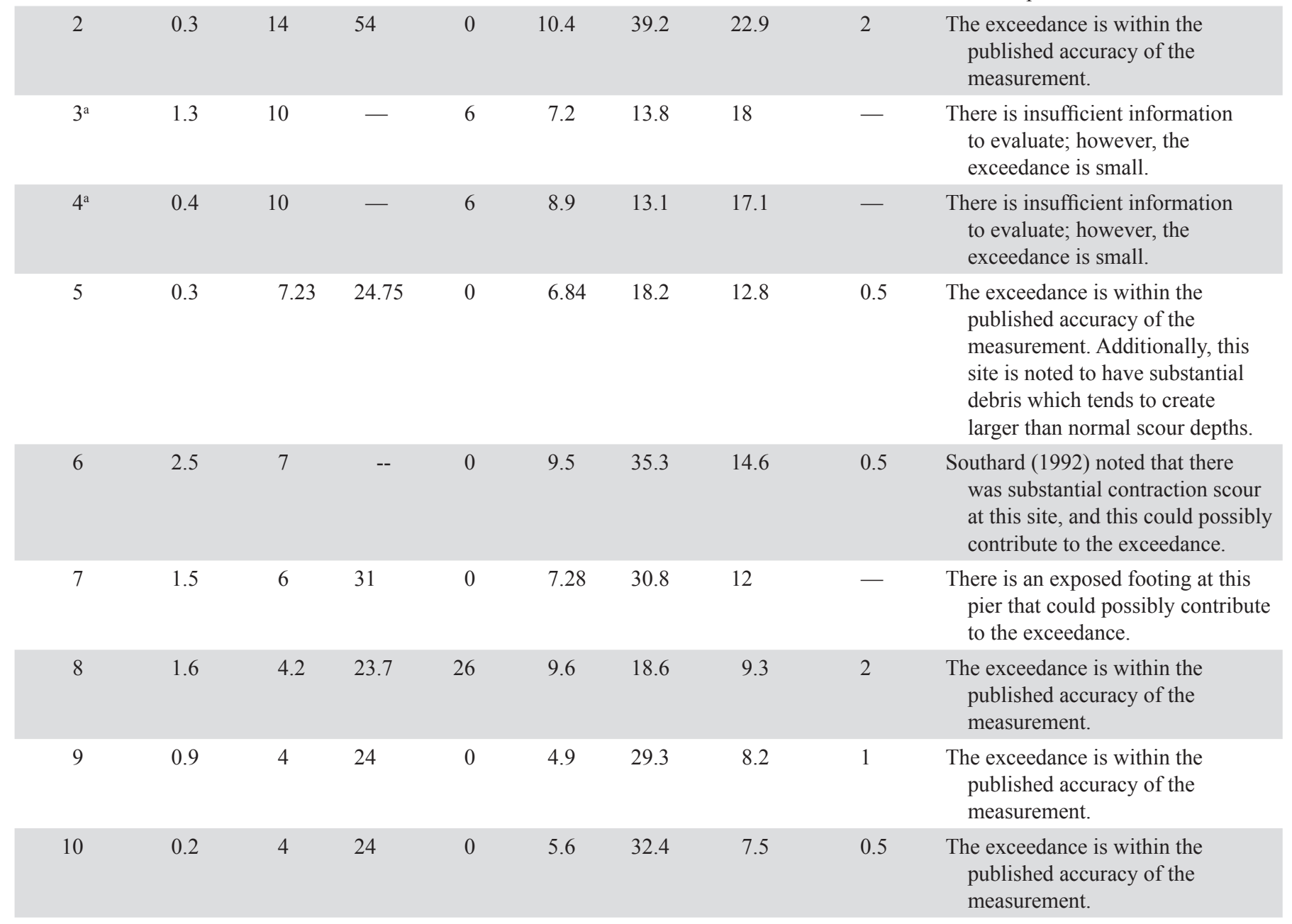


Table 5. Review of selected data points exceeding the PSDb-2014 pier-scour envelope curve.—Continued

[ID, identification; ft, foot; ft/s, foot per second; - , missing data]

\begin{tabular}{|c|c|c|c|c|c|c|c|c|c|}
\hline $\begin{array}{l}\text { ID number } \\
\text { for data } \\
\text { points in } \\
\text { figure } 16\end{array}$ & $\begin{array}{l}\text { Exceedance } \\
\text { of envelope } \\
\text { curve } \\
\text { (ft) }\end{array}$ & $\begin{array}{l}\text { Pier } \\
\text { width } \\
\text { (ft) }\end{array}$ & $\begin{array}{l}\text { Pier } \\
\text { length } \\
\text { (ft) }\end{array}$ & $\begin{array}{c}\text { Skew } \\
\text { angle } \\
\text { (degree) }\end{array}$ & $\begin{array}{l}\text { Flow } \\
\text { velocity } \\
\text { (ft/s) }\end{array}$ & $\begin{array}{l}\text { Flow } \\
\text { depth } \\
\text { (ft) }\end{array}$ & $\begin{array}{l}\text { Measured } \\
\text { scour depth } \\
\text { adjusted } \\
\text { for skew } \\
\text { (ft) }\end{array}$ & $\begin{array}{l}\text { Published } \\
\text { measurement } \\
\text { accuracy } \\
\text { (ft) }\end{array}$ & Comment \\
\hline 11 & 0.2 & 4 & 26 & 0 & 5.3 & 27.2 & 7.5 & 0.5 & $\begin{array}{l}\text { The exceedance is within the } \\
\text { published accuracy of the } \\
\text { measurement. }\end{array}$ \\
\hline 13 & 0.4 & 2.6 & -- & 0 & 11 & 21.2 & 5.4 & - & $\begin{array}{l}\text { There is insufficient information to } \\
\text { evaluate; however, the exceed- } \\
\text { ance is small. }\end{array}$ \\
\hline 14 & 0.4 & 2.5 & 43 & 0 & 1.13 & 26.2 & 5.2 & 1 & $\begin{array}{l}\text { The exceedance is within the pub- } \\
\text { lished accuracy of the } \\
\text { measurement. }\end{array}$ \\
\hline 15 & 3.3 & 1.5 & -- & 0 & 3.3 & 12.4 & 6.3 & - & Insufficient information to evaluate. \\
\hline
\end{tabular}

${ }^{\text {a }}$ This measurement only published the effective pier width, and it is assumed that the measured scour depth reflects the field measurement unadjusted for skew. 


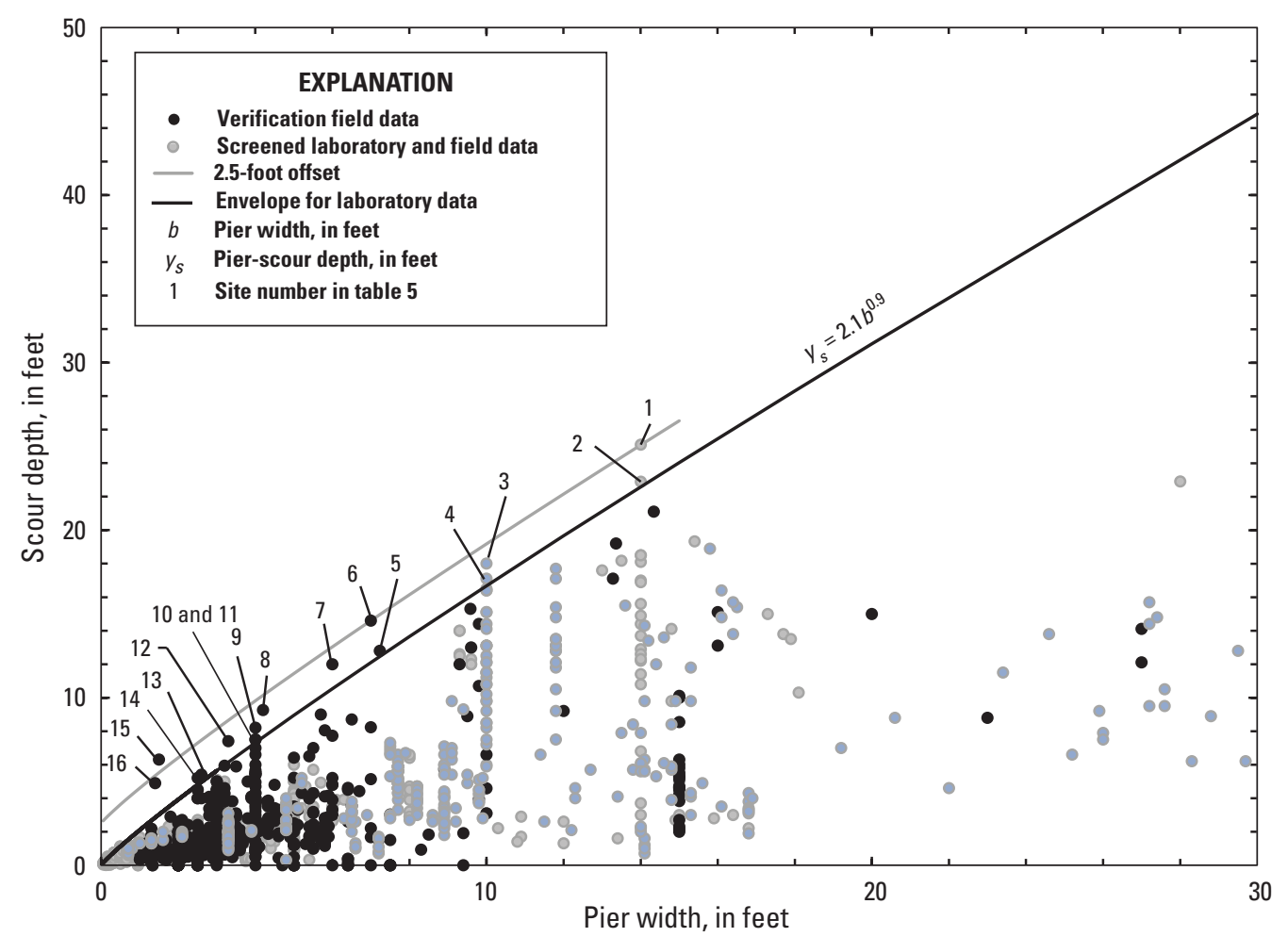

Figure 16. Relation of scour depth to pier width for the screened laboratory and field data and verification data from the PSDb-2014 database (arithmetic scale).

\section{Flow Recurrence Intervals for Data Used in the PSDb-2014 Pier-Scour Envelope Curve}

Through risk analysis and review of historic flow records, Benedict and Caldwell $(2006,2009)$ concluded that flows equal to or exceeding 70 percent of the 100 -year flow (approximately the 25-year flow) likely occurred at a large percentage of the bridges used to develop the South Carolina clear-water and live-bed pier-scour envelope curves (80 and 96 percent, respectively). Additionally, scour measurements in these studies ( 81 and 73 data points, respectively) associated with known historical floods, equal to or exceeding 70 percent of the 100 -year flow, plotted within the envelope curves with some of the data defining the envelope curve. On the basis of these observations, Benedict and Caldwell (2006, 2009) concluded that the South Carolina pier-scour envelope curves represented pier scour for flows near the 100-year flow magnitude.

With respect to the selected field data used to develop the PSDb-2014 envelope curve (screened and verification field data; fig. 15), about 40 percent of the data have estimates of the flow recurrence interval ranging from a 1-year to 500 -year flow magnitude. Sixty-one of those measurements have flow magnitudes equaling or exceeding the 25 -year flow, comparable to the range associated with much of the data used to develop the South Carolina envelope curves. Figure 17 shows the PSDb-2014 pier-scour envelope curve with the field data (screened and verification) grouped by the categories of
(1) unknown recurrence interval, (2) recurrence interval less than the 25-year flow magnitude, and (3) recurrence interval equal to or greater than the 25 -year flow magnitude. The data from category 3 show scatter patterns similar to the analyses of the South Carolina data presented in Benedict and Caldwell (2006, 2009), having a large scatter within the data and the upper bound of the data falling in close proximity to the envelope cure. Although these data are limited, the indication is that the PSDb-2014 pier-scour envelope curve, similar to the South Carolina envelope curves, likely represents pier scour for flows near the 100-year flow magnitude. The South Carolina and PSDb-2014 pier-scour envelope curves provide useful tools for understanding scour associated with flows near the 100-year flow magnitude; however, the envelope curves should not be considered as a definitive estimate of the pier scour associated with the 100-year flow.

\section{Comparison of the South Carolina and PSDb-2014 Pier-Scour Envelope Curves}

The South Carolina clear-water and live-bed pier-scour envelope curves and the PSDb-2014 pier-scour envelope curve are shown in figures 18 and 19, respectively. Arithmetic scales were used in these figures to better display the differences between the South Carolina and PSDb-2014 envelope curves. The South Carolina clear-water envelope curve (fig. 18) plots slightly below the PSDb-2014 envelope curve, 


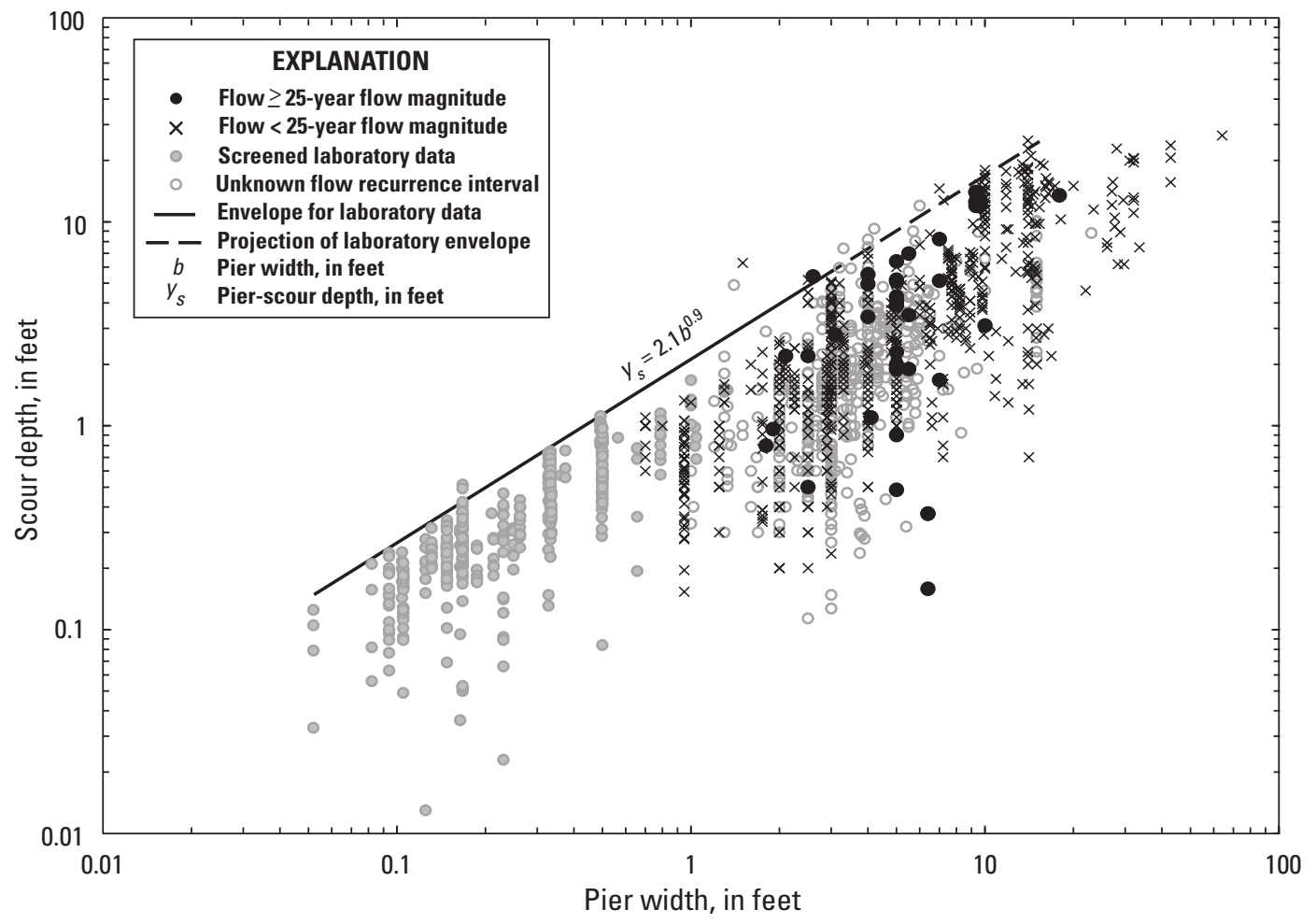

Figure 17. The PSDb-2014 pier-scour envelope curve with field data grouped by recurrence interval.

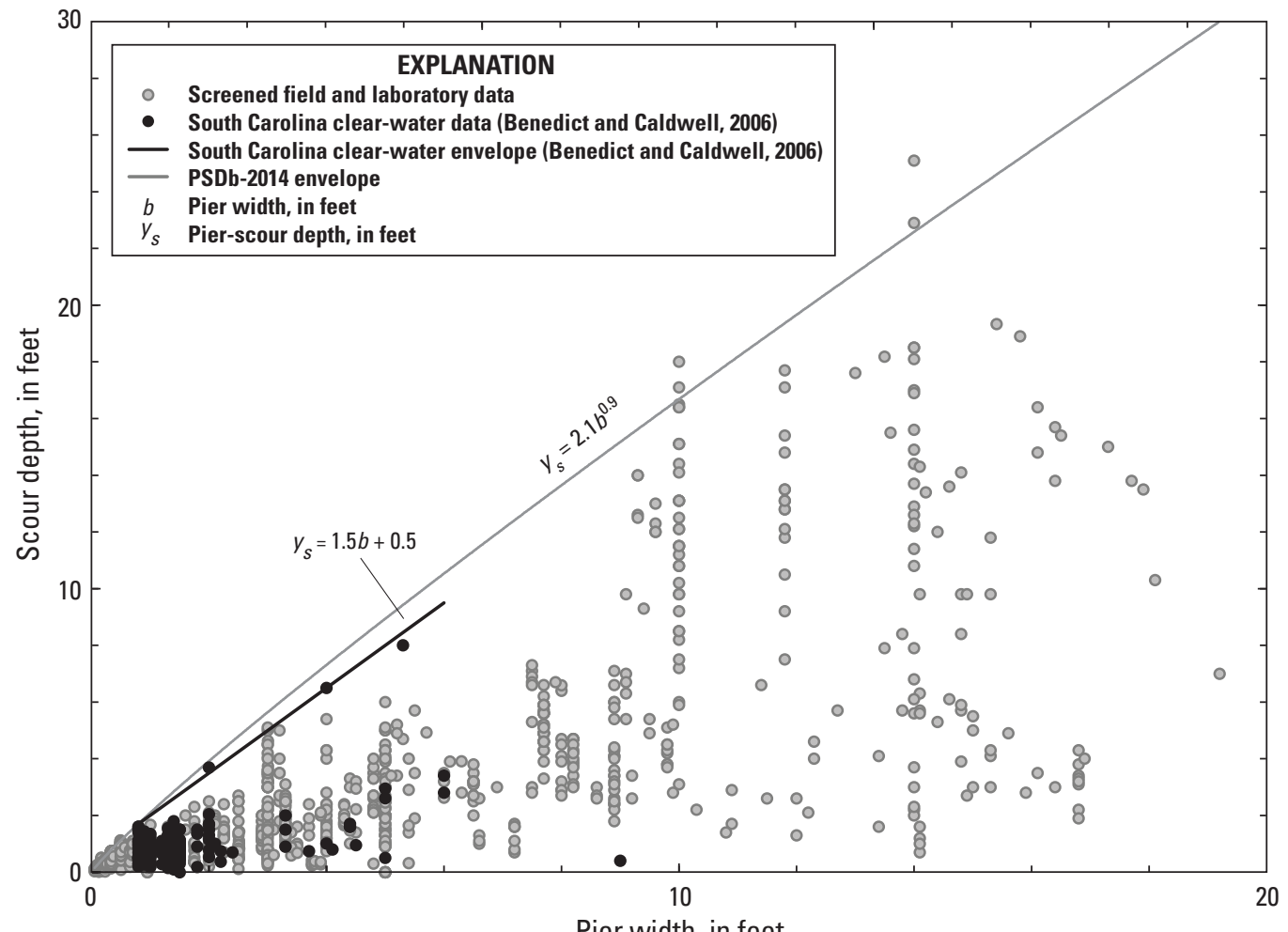

Pier width, in feet

Figure 18. Comparison of the South Carolina clear-water and the PSDb-2014 pier-scour envelope curves. 


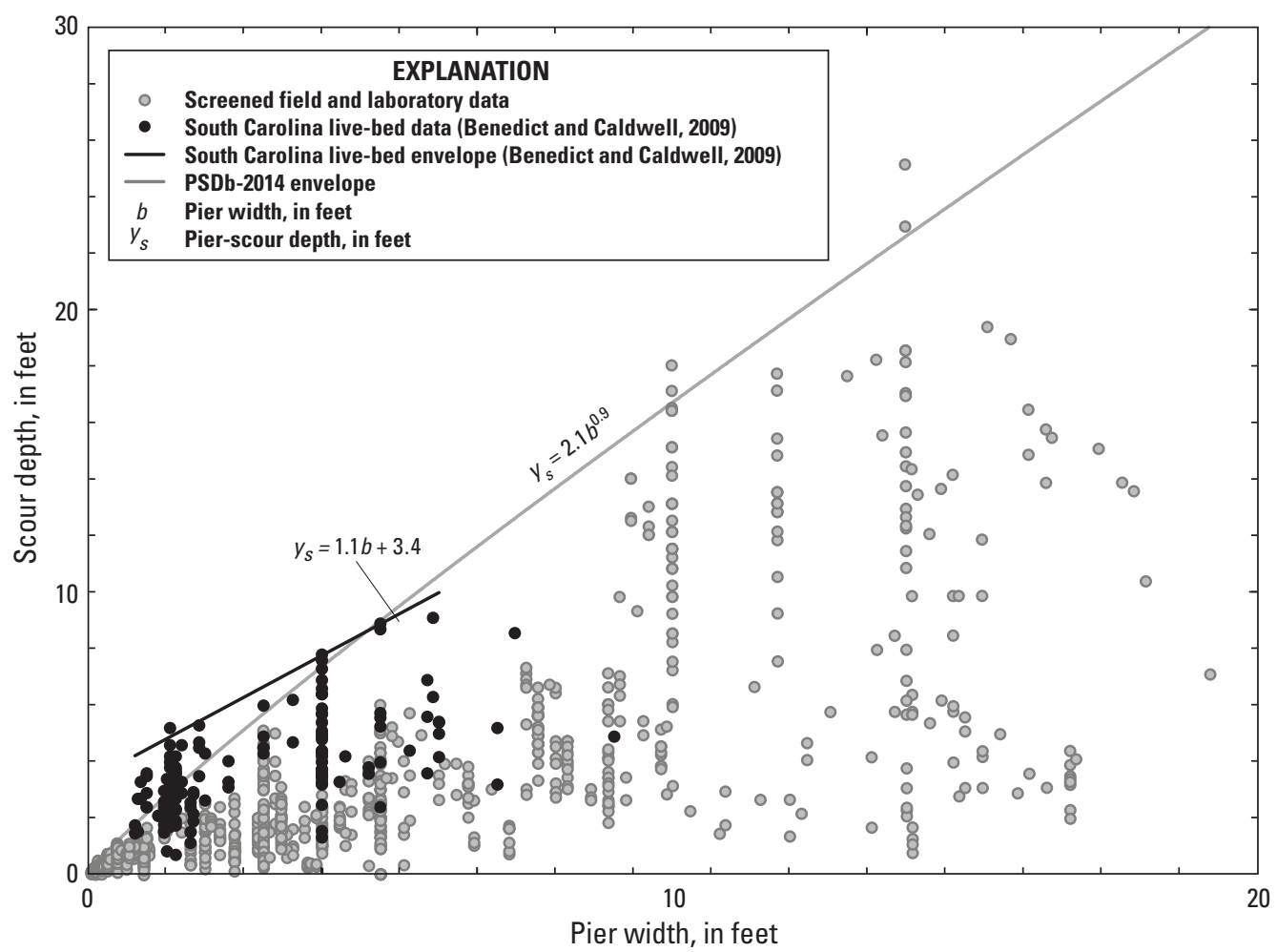

Figure 19. Comparison of the South Carolina live-bed and the PSDb-2014 pier-scour envelope curves.

having an identical scour depth for a nominal pier width of $0.8 \mathrm{ft}$ and being $1 \mathrm{ft}$ smaller for a nominal pier width of $6 \mathrm{ft}$. The South Carolina live-bed envelope curve (fig. 19) primarily plots above the PSDb-2014 envelope curve, having an identical scour depth for a nominal pier width of $5 \mathrm{ft}$, and being $2.6 \mathrm{ft}$ larger for a nominal pier width of $0.8 \mathrm{ft}$. The larger values associated with the South Carolina live-bed envelope curve (fig. 19) can be attributed to the use of GPR that tends to have a larger measurement uncertainty, potentially leading to overestimates of measured scour (Benedict and Caldwell, 2009). Although there are some differences, the South Carolina pier-scour envelope curves fall in close proximity to the PSDb-2014 envelope curve, indicating that the South Carolina pier-scour envelope curves are reasonable.

\section{Relative Increase in Theoretical Pier Scour Associated With the 100- to 500-Year Flows}

As described previously, the South Carolina and PSDb-2014 pier-scour envelope curves included scour measurements likely associated with historic flows near the 100-year flow magnitude; therefore, the envelope curves can be used to assess scour potential for such flow conditions. (Note: Although the South Carolina and PSDb-2014 pier-scour envelope curves include a number of measurements likely associated with flows near the 100-year flow magnitude, the envelope curves should not be considered as a definitive estimate of the pier scour associated with the 100-year flow.) The South Carolina pier-scour envelope curves were not recommended for assessing scour potential for extreme floods such as the 500-year flow (Benedict and Caldwell, 2006, 2009), and this guidance also is appropriate for the PSDb-2014 envelope curve. In order to gain insights on the relative increase in pier-scour depth associated with the 100 - to 500 -year flows, it is possible to develop theoretical adjustment coefficients that approximate that relative change. Such coefficients can be applied to the pier-scour envelope curves to approximate the relative increase in scour associated with the 100- to 500-year flows. Although such adjustments do not provide a definitive estimate of the 500 -year pier-scour depth, they do provide perspective on the relative increase. To accomplish this task, theoretical pier-scour computations from previous level-2 scour evaluations, conducted by the USGS, were compiled into a database and used to evaluate the relative increase in scour depth associated with the 100-year flow to the 500-year flow for theoretical pier-scour depths. A summary of the compiled theoretical scour data and the analysis of the 500 -year flow adjustment coefficient is presented below. 


\section{Theoretical Pier-Scour Data}

The USGS, in cooperation with the SCDOT, conducted level-2 bridge-scour studies at 293 bridges in South Carolina (1992-95), using methods presented in HEC-18 (Richardson and others, 1991, 1993). These studies included the development of one-dimensional step-backwater flow models for the 100- and 500-year flows (Guimaraes and Bohman, 1992) and theoretical bridge-scour computations for both flow conditions using the HEC-18 scour equations (Richardson and others, 1991, 1993). Selected theoretical bridge-scour data for the 100- and 500-year flows, as determined in the level-2 scour investigations, were compiled into a digital spreadsheet and called the South Carolina Theoretical Bridge Scour Database. This database is included as a companion spreadsheet with this report and is available at https://doi.org/10.3133/ sir20165121. The South Carolina Theoretical Bridge Scour Database includes theoretical scour computations for both the 100 - and 500-year flows at 1,645 piers. In addition to the South Carolina data, theoretical pier-scour data from level-2 studies conducted in Missouri (Huizinga and Rydlund, 2004) also were used in the analysis. The Missouri data included theoretical scour computations for 187 piers and were used as a means to confirm the trends of the South Carolina data. The Missouri data are available at http://pubs.usgs.gov/sir/2004/5213/.

\section{The 500-Year Flow Adjustment Coefficient}

The relation of the theoretical pier scour for the 100- and 500-year flows for the South Carolina and Missouri data is shown in figure 20 including trend lines through each dataset. As previously noted, the purpose of this analysis is to provide perspective on the relative increase in scour depth for the 100- and 500-year flows and not to provide a definitive estimate of the 500-year scour depth. Consequently, the analysis was done such that the intercept in the linear equation would be zero, resulting in a 500-year flow adjustment coefficient that is a constant, which simplifies the application of the coefficient. The resulting curves as shown in figure 20 and similar curves from analyses for the other scour components presented later in the report indicate this is a reasonable approach. Summary statistics for the data are provided in table 6. The scatter about the trend line for the South Carolina data is small, and the coefficient of determination is high (0.99) indicating that there is a strong correlation in the data. The trend line through the Missouri data falls in close proximity to the South Carolina trend line indicating that the South Carolina trend line is reasonable. The equation for the South Carolina trend line is as follows:

$$
\text { Scour }_{500}=1.09 \text { Scour }_{100}
$$

where

$$
\begin{gathered}
\text { Scour }_{500} \begin{array}{l}
\text { is the 500-year flow theoretical scour } \\
\text { depth, in feet; and }
\end{array} \\
\text { Scour }_{100} \quad \begin{array}{c}
\text { is the } 100 \text {-year flow theoretical scour } \\
\text { depth, in feet. }
\end{array}
\end{gathered}
$$

Equation 11 can be divided by Scour $_{100}$ and simplified to the following form:

$$
K_{500}=1.09
$$

where $K_{500}$ is the theoretical 500-year flow adjustment coefficient that represents the ratio of the 500-year flow to 100 -year flow theoretical pier-scour depths. The $K_{500}$ coefficient can be applied to the South Carolina and PSDb-2014 pier-scour envelope curves to increase the envelope pier-scour depth by the relative increase in theoretical pier scour associated with the 100 - to 500 -year flow condition. The $K_{500}$ is a helpful tool for gaining perspective on the relative increase of theoretical scour associated with the 100- to 500-year pier-scour depth. However, the adjusted envelope curve values, should not be

\begin{tabular}{|c|c|c|c|c|}
\hline \multirow{2}{*}{$\begin{array}{l}\text { Descriptive } \\
\text { statistic }\end{array}$} & \multicolumn{2}{|c|}{ South Carolina $(\mathbf{N}=1,645)$} & \multicolumn{2}{|c|}{ Missouri ( $\mathbf{N}=187$ ) } \\
\hline & $\begin{array}{l}\text { Ratio of } 0500 \text { and } 0100 \\
\text { theoretical pier-scour depths }\end{array}$ & $\begin{array}{l}\text { Drainage area } \\
\qquad\left(\mathrm{mi}^{2}\right)\end{array}$ & $\begin{array}{l}\text { Ratio of } 0500 \text { and } 0100 \\
\text { theoretical pier-scour depths }\end{array}$ & $\begin{array}{l}\text { Drainage area } \\
\qquad\left(\mathrm{mi}^{2}\right)\end{array}$ \\
\hline Minimum & 1.00 & 0.91 & 1.00 & 3.70 \\
\hline 25 th percentile & 1.06 & 46.6 & 1.08 & 15.1 \\
\hline Mean & 1.10 & 760 & 1.19 & 244 \\
\hline Median & 1.08 & 144 & 1.13 & 44.4 \\
\hline 75th percentile & 1.12 & 553 & 1.20 & 170 \\
\hline Maximum & 1.81 & 8,312 & 2.40 & 14,000 \\
\hline
\end{tabular}
considered a definitive estimate of the pier scour associated with the 500-year flow.

Table 6. Descriptive statistics for the ratio of the 500- and 100-year flow, theoretical pier-scour depths used in the regression analysis for selected data from South Carolina and Missouri.

[N, number of measurements; Q500, 500-year flow; Q100, 100-year flow; $\mathrm{mi}^{2}$, square mile] 


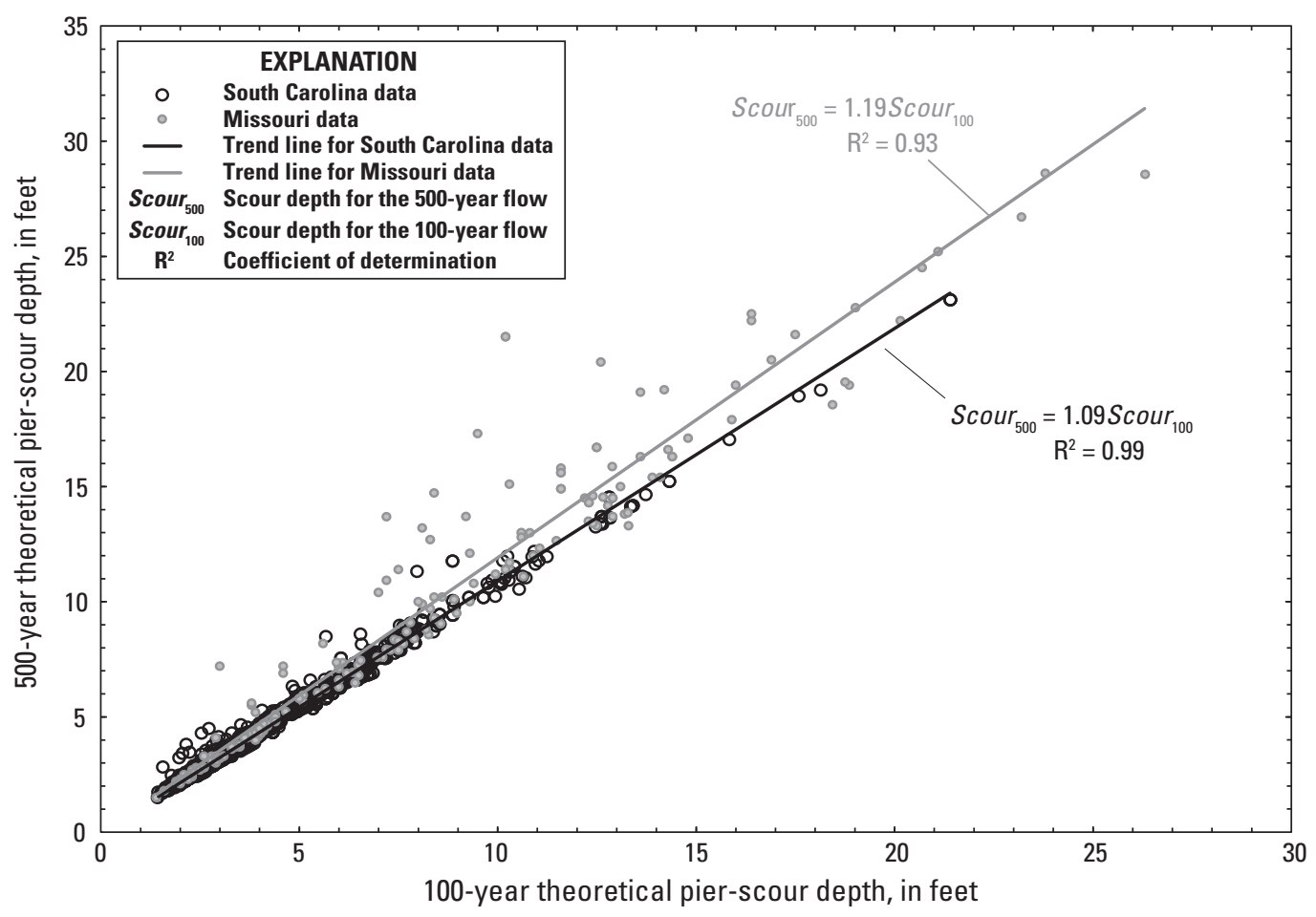

Figure 20. Relation of the 500- and 100-year flow, theoretical pier-scour depths for selected data from level-2 bridge-scour studies in South Carolina and Missouri.

\section{Application and Limitations of the PSDb-2014 and South Carolina Clear-Water and Live-Bed Pier-Scour Envelope Curves}

Estimating pier-scour depth with current scour-prediction methods from HEC-18 (Arneson and others, 2012) is an imprecise science, and the practitioner must use judgment to evaluate the reasonableness of the results. The PSDb-2014 and the South Carolina clear-water and live-bed pier-scour envelope curves are useful supplementary tools that can be used to assist in such evaluations. However, the limitations associated with the envelope curves, as noted below, should be kept in mind when using them to assess scour potential in South Carolina. The pier-scour envelope curves are empirical formulations, and therefore, their application should be limited to sites having similar characteristics to those used to develop the envelope curves. The envelope curves do not account for adverse field conditions, such as debris, severe channel bends, and unusual flow distributions, and judgment must be used to assess the increased potential for pier scour when such conditions exist or are anticipated. The envelope curves are not intended for tidally influenced sites. The envelope curves were developed from a limited sample of bridges, and scour depths possibly could exceed the envelope curves; therefore, applying a safety factor to the envelope curves may be prudent. Application of the South Carolina clear-water and live-bed envelope curves is limited to nominal pier widths of approximately $6 \mathrm{ft}$ or less. The PSDb-2014 envelope curve can be applied to nominal pier widths approximately $15 \mathrm{ft}$ or less. The following guidance for applying the pier-scour envelope curves is separated into categories for nominal pier widths less than or equal to $6 \mathrm{ft}$ and for nominal pier widths greater than $6 \mathrm{ft}$.

\section{Evaluating Scour Depth at Pier Widths Less Than or Equal to 6 Feet}

The South Carolina clear-water and live-bed pier-scour envelope curves (figs. 7 and 10, respectively) can be used as supplementary tools to evaluate pier-scour potential for flood plain or main-channel piers, respectively, having nominal pier widths less than or equal to $6 \mathrm{ft}$. The PSDb-2014 envelope curve (fig. 14) also is applicable for this range of nominal pier widths. Following is guidance for application of these envelope curves. 


\section{Clear-Water Pier Scour on the Flood Plain}

1. Determine if the site of interest has characteristics within the range of the data used to develop the envelope curve by reviewing the corresponding regional data in table 1 .

2. Evaluate the correction coefficient for skew $\left(K_{2}\right)$.

- Pile bents:

- For pile bents with skews approximately 15 degrees or less and spacings between piles of approximately 5 pile widths or greater, $K_{2}$ has a value of 1.0. If adverse field conditions exist or are anticipated at the site, use of equation 4 following the guidance as recommended in HEC-18 (Arneson and others, 2012) may be appropriate.

- For pile bents with skews exceeding approximately 15 degrees or with spacings between piles smaller than 5 pile widths, evaluate $K_{2}$ with equation 4 following the guidance as recommended in HEC-18 (Arneson and others, 2012).

- Piers:

- For skewed piers, evaluate $K_{2}$ with equation 4 following the guidance as recommended in HEC-18 (Arneson and others, 2012).

3. Evaluate the upper bound of clear-water pier scour on the flood plain with equation 3 .

4. Select comparison sites from the South Carolina Clear-Water Pier- and Contraction-Scour Database (SCPCSD; Benedict and Caldwell, 2006) having characteristics similar to the site of interest, and evaluate the reasonableness of the assessment of potential pier scour. The PSDb-2014 database (Benedict and Caldwell, 2014) may be consulted for additional comparisons if deemed appropriate.

5. Evaluate the relative increase in theoretical pier scour associated with the 100- to 500 -year flow by multiplying the results from equation 3 by the $K_{500}$ coefficient from equation 12 .

\section{Live-Bed Pier Scour in the Main Channel}

1. Determine if the site of interest has characteristics within the range of the data used to develop the envelope curve by reviewing the corresponding regional data in table 2 .

2. Evaluate the correction coefficient for skew $\left(K_{2}\right)$.

- Pile bents:

- For pile bents with skews approximately 15 degrees or less and spacings between piles of approximately 5 pile widths or greater, $K_{2}$ has a value of 1.0. If adverse field conditions exist or are anticipated at the site, use of equation 4 following the guidance as recommended in HEC-18 (Arneson and others, 2012) may be appropriate.

- For pile bents with skews exceeding approximately 15 degrees or with spacings between piles smaller than 5 pile widths, evaluate $K_{2}$ with equation 4 following the guidance as recommended in HEC-18 (Arneson and others, 2012).

- Piers:

- For skewed piers, evaluate $K_{2}$ with equation 4 following the guidance as recommended in HEC-18 (Arneson and others, 2012).

3. Evaluate the upper bound of live-bed pier scour in the main channel with equation 7 .

4. Select comparison sites from the South Carolina Live-Bed Scour Database (SCLBSD; Benedict and Caldwell, 2009) having characteristics similar to the site of interest, and evaluate the reasonableness of the assessment of potential pier scour. The PSDb-2014 database (Benedict and Caldwell, 2014) may be consulted for additional comparisons if deemed appropriate.

5. Evaluate the relative increase in theoretical pier scour associated with the 100 - to 500 -year flow by multiplying the results from equation 7 by the $K_{500}$ coefficient as determined from equation 12 .

\section{The PSDb-2014 Pier-Scour Envelope Curve}

It is possible to use the PSDb-2014 pier-scour envelope curve to assess clear-water and live-bed pier-scour potential for pier widths less than or equal to $6 \mathrm{ft}$. The PSDb-2014 envelope curve will tend to provide slightly larger estimates of pier-scour depth than the South Carolina clear-water pier-scour envelope curve (fig. 18) and slightly lower values than the South Carolina live-bed pier-scour envelope curve (fig. 19).

1. Determine if the site of interest has characteristics within the range of the data used to develop the envelope curve by reviewing table 4 .

2. Evaluate the correction coefficient for skew, $K_{2}$, following the guidance as recommended in HEC-18 (Arneson and others, 2012).

3. Evaluate the upper bound of pier scour by applying the nominal pier width and $K_{2}$ to equation 10 .

4. Select comparison sites from the PSDb-2014 database having characteristics similar to the site of interest, and evaluate the reasonableness of the assessment of potential pier scour.

5. Evaluate the relative increase in theoretical pier scour associated with the 100 - to 500 -year flow by multiplying the results from equation 10 by the $K_{500}$ coefficient as determined from equation 12 . 


\section{Evaluating Scour Depth at Pier Widths Greater Than 6 Feet}

The PSDb-2014 envelope curve (fig. 13) can be used as a supplementary tool to evaluate pier-scour potential for flood plain and main-channel piers having nominal pier widths of $15 \mathrm{ft}$ or less. The guidance presented in the previous report section can be followed for applying the PSDb-2014 envelope curve. (Note: Benedict and Caldwell [2009] recommended using the pier-scour envelop curve shown in figure 12 on the basis of a limited set of pier-scour data from the NBSD for nominal pier widths greater than $6 \mathrm{ft}$. However, the PSDb-2014 envelope curve is based on a much larger dataset and should supersede the limited NBSD envelope curve.)

\section{The South Carolina Clear-Water Abutment-Scour Envelope Curves}

Local scour at an abutment is caused by the obstruction of flow created by a road embankment. The flow contraction forced by the road embankment creates a complex flow field causing accelerated flows and vortexes near the toe of the abutment (fig. 21); these are considered the primary mechanisms that produce abutment scour (Ettema and others, 2010; Sturm and others, 2011). Figure 22 shows a simplified flow field at a bridge contraction, identifying the zone of flow acceleration and severe flow curvature near the abutment toe, which produces the abutment scour. With lateral distance from the abutment, the flow curvature and acceleration diminishes decreasing the potential for scour. This decreased potential of scour is typically associated with clear-water contraction scour on bridge overbanks. Figure 23 shows the general regions of clear-water abutment and contraction scour on a bridge overbank that correspond to the flow patterns depicted in figure 22. The flow patterns in the abutment-scour region will tend to produce larger scour depths than those in the clear-water contraction-scour region, and the more severe the contraction of flow, the larger the potential for scour depth in both regions. Although abutment scour can be classified as clear-water or live-bed scour, clear-water abutment scour was the focus of the South Carolina investigation (Benedict, 2003). As previously described in the report section "Clear-Water Pier-Scour Envelope Curve," clear-water scour conditions prevail on the flood plains of South Carolina streams, and clear-water abutment scour typically occurs in close proximity to the abutment toe (fig. 23) in the clear-water scour areas as defined in figures 4 and 5 .

The complexity of the abutment scour processes (fig. 21) and the difficulty of scaling long road embankments to the laboratory flume present challenges for investigating abutment scour in the laboratory setting. As such, the state-of-the knowledge for abutment scour processes is not as advanced as that for pier scour (Ettema and others, 2010; Sturm and others, 2011). A number of laboratory studies have been conducted to investigate the variables that influence abutment scour. Some of the more notable publications on this topic include Laursen and Toch (1956), Das (1973), Melville (1992), Dongol (1993), Palaviccini (1993), Melville and Coleman (2000), Sturm (2004), Briaud and others (2009), Ettema and others (2010), and Sturm and others (2011). Although some have differing views regarding the most prominent variables that influence abutment scour, researchers generally agree that influencing variables include the velocity of approaching flow, the depth of approaching flow, flow duration, sediment characteristics, abutment geometry, abutment alignment with flow, embankment length blocking flow, and the degree of flow contraction.

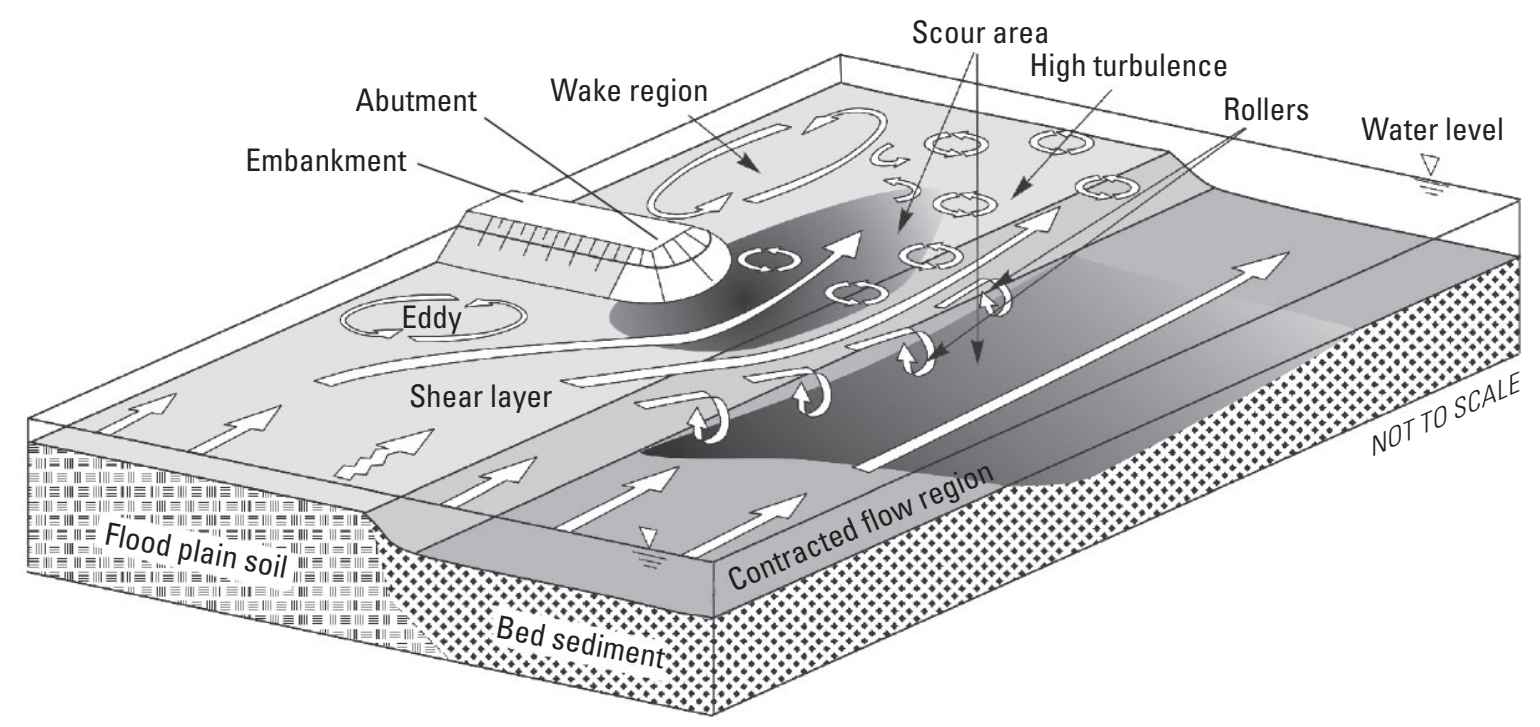

Figure 21. Flow around a bridge abutment and embankment and resulting scour (from Ettema and others, 2010). 


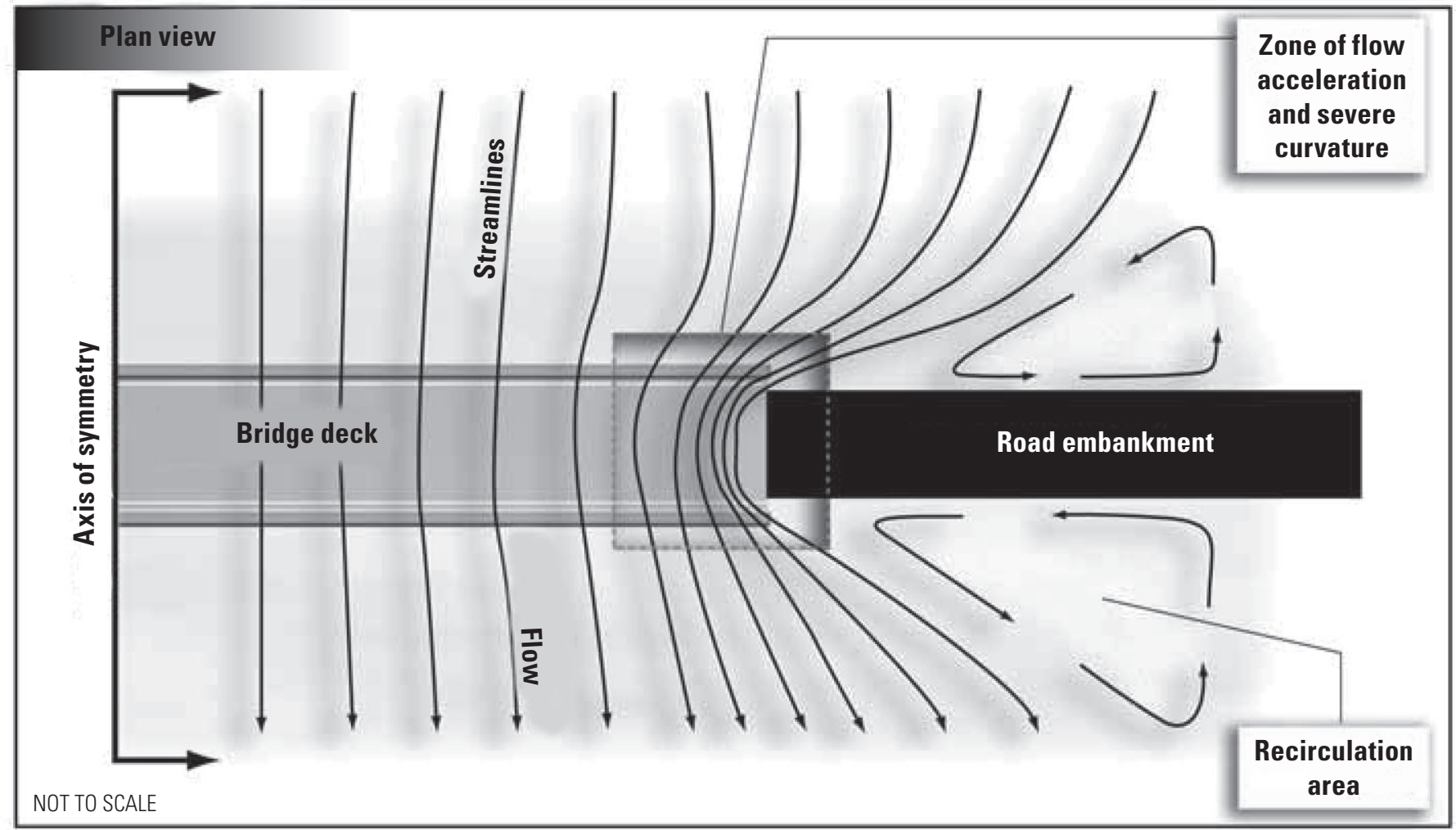

Figure 22. Plan view of simplified flow field at a bridge contraction (from Benedict, 2003).

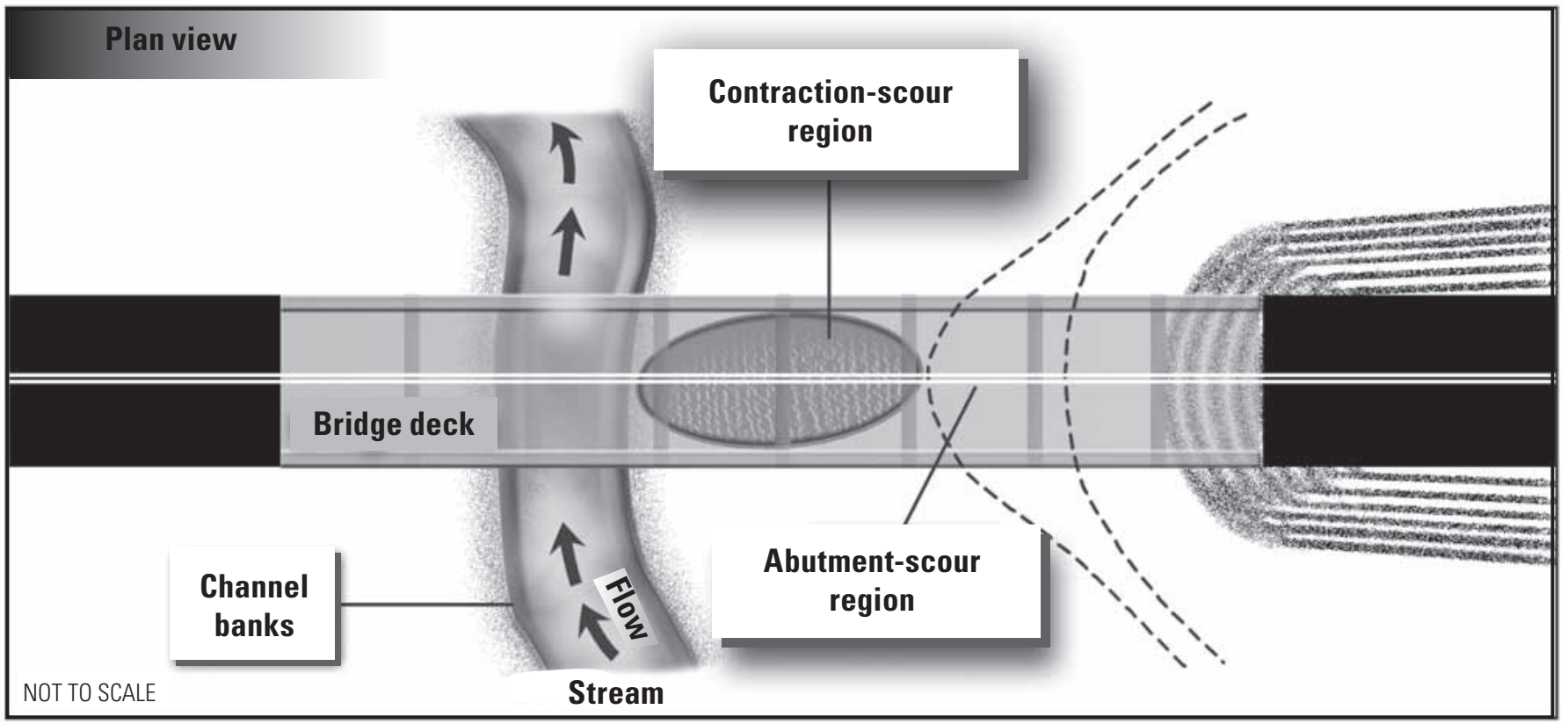

Figure 23. Plan view of regions of clear-water abutment and contraction scour (from Benedict, 2003). 
Some researchers have considered the embankment length blocking flow, a geometric variable, as a primary explanatory variable for abutment scour (Melville, 1992; Dongol, 1993; Melville and Coleman, 2000). (Note: Some researchers use the term "abutment length" rather than "embankment length." These terms should be considered synonymous in this report.) Others have considered the degree of flow contraction created by the road embankment as a primary explanatory variable (Laursen and Toch, 1956; Das, 1973; Chang and Davis, 1999; Sturm, 2004; Ettema and others, 2010), with scour depth generally increasing as the severity of contraction increases. Although the embankment length blocking flow and the degree of contraction are different variables, they are strongly correlated such that as one increases the other generally increases. A notable example of an abutment-scour prediction equation that utilizes the embankment length blocking flow as a primary explanatory variable is the Froehlich (1989) equation, which is the predictive equation recommended in HEC-18 (Arneson and others, 2012). An example of an abutment-scour prediction equation that utilizes the degree of flow contraction as a primary explanatory variable is the NCHRP 24-20 equation (Ettema and others, 2010), which is an alternate predictive equation recommended in HEC-18 (Arneson and others, 2012). On the basis of the findings from laboratory investigations, Benedict (2003) developed field-derived envelope curves for clear-water abutment scour, using the embankment length blocking flow and the degree of contraction (expressed by the geometric-contraction ratio) as the primary explanatory variables. An overview of the South Carolina abutment-scour envelope curves and a comparison with laboratory and field data from other sources follows.

\section{South Carolina Clear-Water Abutment-Scour Field Data}

Benedict (2003) made 209 measurements of clear-water abutment scour at selected sites in South Carolina, with 100 measurements in the Piedmont (table 7) and 109 in the Coastal Plain (table 7). Bridge sites where clear-water abutment-scour data were collected can be identified in appendix 1 and figure 1. Measurements of abutment-scour depths made in both provinces ranged from 0 to $23.6 \mathrm{ft}$ and were assumed to represent the maximum clear-water abutment-scour depth that has occurred at the bridge since construction. All measurements were associated with abutment scour in the flood plain in the clear-water scour area located at the bridge (figs. 4,5 ), and the reference surface used to

Table 7. Range of selected characteristics of clear-water abutment scour field data in the flood plains of selected sites in South Carolina (Benedict, 2003).

$\left[\mathrm{mi}^{2}\right.$, square mile; ft/ft, foot per foot; $\mathrm{ft} / \mathrm{s}$, foot per second; ft, foot; mm, millimeter; $D_{\text {sadj }}$, abutment-scour depth adjusted for abutment shape and skew; $<$, less than]

\begin{tabular}{|c|c|c|c|c|c|c|c|c|c|c|}
\hline $\begin{array}{l}\text { Range } \\
\text { value }\end{array}$ & $\begin{array}{c}\text { Drainage } \\
\text { area } \\
\left(\mathrm{mi}^{2}\right)\end{array}$ & $\begin{array}{c}\text { Channel } \\
\text { slope } \\
(\mathrm{ft} / \mathrm{ft})\end{array}$ & $\begin{array}{c}\text { aAverage } \\
\text { approach } \\
\text { velocity } \\
\text { (ft/s) }\end{array}$ & $\begin{array}{l}\text { a,bAverage } \\
\text { approach } \\
\text { flow } \\
\text { depth }(y) \\
\text { (ft) }\end{array}$ & $\begin{array}{l}\text { aEmbankment } \\
\text { length } \\
\text { blocking } \\
\text { flow (L) } \\
\text { (ft) }\end{array}$ & $\begin{array}{c}\text { Median } \\
\text { grain size } \\
(\mathrm{mm})\end{array}$ & $\begin{array}{l}\text { Measured } \\
\text { scour } \\
\text { depth }\left(D_{s}\right) \\
(f t)\end{array}$ & $\begin{array}{c}{ }^{\mathrm{c}} \text { Relative } \\
\text { abutment } \\
\text { length } \\
(L / y)\end{array}$ & $\begin{array}{l}\text { 'Relative } \\
\text { scour } \\
\text { depth } \\
\left(D_{\text {sadj }} / y\right)\end{array}$ & $\begin{array}{c}\text { a,c Geometric } \\
\text { contraction } \\
\text { ratio } \\
(m)\end{array}$ \\
\hline \multicolumn{11}{|c|}{ South Carolina Piedmont (100 measurements) } \\
\hline Minimum & 11 & 0.0002 & 0.1 & 1.0 & 18 & $<0.062$ & 0 & 3.0 & 0.0 & 0.0 \\
\hline Maximum & $1,620^{\mathrm{d}}$ & 0.0029 & 3.2 & 14.6 & $953^{\mathrm{e}}$ & 0.99 & 18 & 230 & 3.0 & 0.9 \\
\hline \multicolumn{11}{|c|}{ South Carolina Coastal Plain (109 measurements) } \\
\hline Minimum & 6.1 & 0.00007 & 0.1 & 1.5 & 87 & $<0.062$ & 0 & 20.5 & 0 & 0.51 \\
\hline Median & 120 & 0.00054 & 0.5 & 4.7 & 557 & 0.18 & 7 & 125.6 & 1.51 & 0.86 \\
\hline
\end{tabular}

${ }^{a}$ Values were estimated from a one-dimensional water-surface profile model.

${ }^{b}$ For setback abutments on the flood plain, flow depth is the average approach flood plain flow depth. For abutments set at the channel bank or protruding into the channel, flow depth is the average approach channel flow depth.

${ }^{c}$ Values reported in Benedict (2016).

${ }^{\mathrm{d} A p p r o x i m a t e l y} 97$ percent of the study sites in the Piedmont have drainage areas less than $400 \mathrm{mi}^{2}$ (fig. 40).

${ }^{\mathrm{e}}$ Three observations had embankment lengths exceeding $950 \mathrm{ft}$ and were significantly outside the range for the majority of the Piedmont data. These sites were excluded from development of the embankment-length envelope curve; therefore, the range of Piedmont embankment lengths used in this study should be limited to $950 \mathrm{ft}$.

${ }^{\mathrm{f}}$ Approximately 80 percent of the study sites in the Coastal Plain have drainage areas less than $426 \mathrm{mi}^{2}$ (fig. 40 ).

${ }^{g}$ Only seven measurements have embankment lengths that exceed 2,000 ft. 
determine the scour depth was the average undisturbed flood plain elevation in the vicinity of the observed scour. Because of clear-water scour conditions, infill sediments within the scour holes were, in general, negligible. The dominant abutment geometry was the spill-through abutment, which was observed at all but three bridges. The remaining three bridges had vertical wingwall abutments. A grab sample of the flood plain surface sediment was obtained in the upstream flood plain at each site and was analyzed to estimate the median grain size. Because sediment characteristics in the field setting can vary substantially in the vertical and horizontal direction, a grab sample taken at a point may not fully represent the sediment characteristics at a site.

The South Carolina clear-water abutment-scour depths were measured during low flows, and the flow conditions that produced the scour are not known. To estimate the hydraulic characteristics that may have produced the observed abutment scour, WSPRO (Shearman, 1990; Arneson and Shearman, 1998) models were developed for each site. A review of historic floods in South Carolina and a risk analysis associated with the bridge age indicated that about 90 percent of the bridges in the study likely had experienced flows equaling or exceeding approximately 70 percent of the 100-year flow, with approximately 25 percent of the bridges having known historical floods that equaled or exceeded 70 percent of the 100-year flow value. Information on sites with known historical floods can be found in appendix 2. On the basis of the review of historic floods and the risk analysis, the 100-year flow was assumed to be representative of a common flow that may have occurred at all bridges, and this flow was used in the WSPRO model to estimate the flow characteristics that may have produced the measured scour. These estimated flow characteristics, which include the embankment length blocking flow and the geometric-contraction ratio, should be viewed as approximate rather than measured data.

The clear-water abutment-scour data collected in South Carolina were grouped into two datasets based on regional location within the State (fig. 1). One dataset contained data collected in the Piedmont and the other contained data collected in the Coastal Plain. (Note: The Coastal Plain dataset did not include bridges that were tidally influenced during high flows.) This division of the data was justified because of the distinct regional characteristics associated with the streams of the Piedmont and Coastal Plain Provinces. The Piedmont generally has cohesive flood plain soils, moderate stream gradients, relatively narrow flood plains, and relatively short flood-flow durations. In contrast, the Coastal Plain generally has sandy flood plain soils, low gradient streams, relatively wide flood plains, and relatively long flood-flow durations. To provide some understanding of the differences between these regions, the median and range of selected site characteristics for the clear-water abutment-scour field data collected in the Piedmont and Coastal Plain are listed in table 7. For additional details regarding the South Carolina clear-water abutmentscour data, reference can be made to Benedict (2003).

\section{Field Conditions That Influence Clear-Water Abutment-Scour Potential}

Benedict (2003) identified selected field conditions in the South Carolina abutment-scour data that at times were associated with large abutment-scour depths thus indicating an increased potential for abutment scour. These conditions included (1) wide, flat flood plains where bridges often create more severe contractions of flow; (2) flood plain land cover (clear cut and pastures) that reduced flood plain flow resistance and thereby increased the flow velocities approaching the abutment; and (3) severe upstream channel bends that redirected concentrated channel flows during a flood toward an abutment that typically would not experience this magnitude of flow if the channel were straight. A review of aerial photography and topographic maps can help identify these field conditions, providing insights into the potential for abutment scour at a given site. In addition to these field characteristics, large abutment scour depths were often associated with bridges having long embankment lengths blocking flow and large geometric-contraction ratios, which are highlighted in the abutment-scour envelope curves described later in the report.

Benedict (2003) also noted that bridges over swampy channels or flood plain relief bridges (fig. 5) approximately $240 \mathrm{ft}$ or less in length tended to form a large, single scour hole that encompassed the entire bridge opening from abutment toe to abutment toe (fig. 24). In contrast, bridges greater than $240 \mathrm{ft}$ in length generally formed separate abutment scour holes at the left and right abutments (fig. 25). This phenomenon at shorter bridges appeared to be caused by the overlap of the accelerated, turbulent, and curvilinear flow (figs. 21, 22) coming from around the left and right abutments. At longer bridges, the overlap of the left and right abutment flow patterns does not occur, and separate left and right abutment-scour holes are formed. Although the large, single scour holes associated with the shorter bridges could be classified as contraction scour, the accelerated, turbulent, and curvilinear flow patterns that create the scour at these shorter bridges is similar to the flow patterns associated with abutment scour (figs. 21, 22) at the longer bridges; therefore, it was assumed that these scour holes should be classified as abutment scour. To associate the single scour holes at these shorter bridges with abutment variables, it was assumed that the longer of the left or right embankment length blocking flow provided the stronger influence in developing the scour hole and was associated with the observed scour. Benedict (2003) also noted that the upper bound of scour depth for the shorter bridges (fig. 24) generally was about 3 to $4 \mathrm{ft}$ larger than for the longer bridges, indicating that shorter bridges, which are often associated with large flow contractions, tend to have a larger potential for abutment-scour depth. Additional details on the above noted field conditions and their influence on abutment scour can be found in Benedict (2003). 
Figure 24. Example of single scour hole at shorter bridges, as shown at structure 212030100100 on U.S. Route 301 crossing Douglas Swamp in Florence County, South Carolina, July 31, 1996 (from Benedict, 2003).

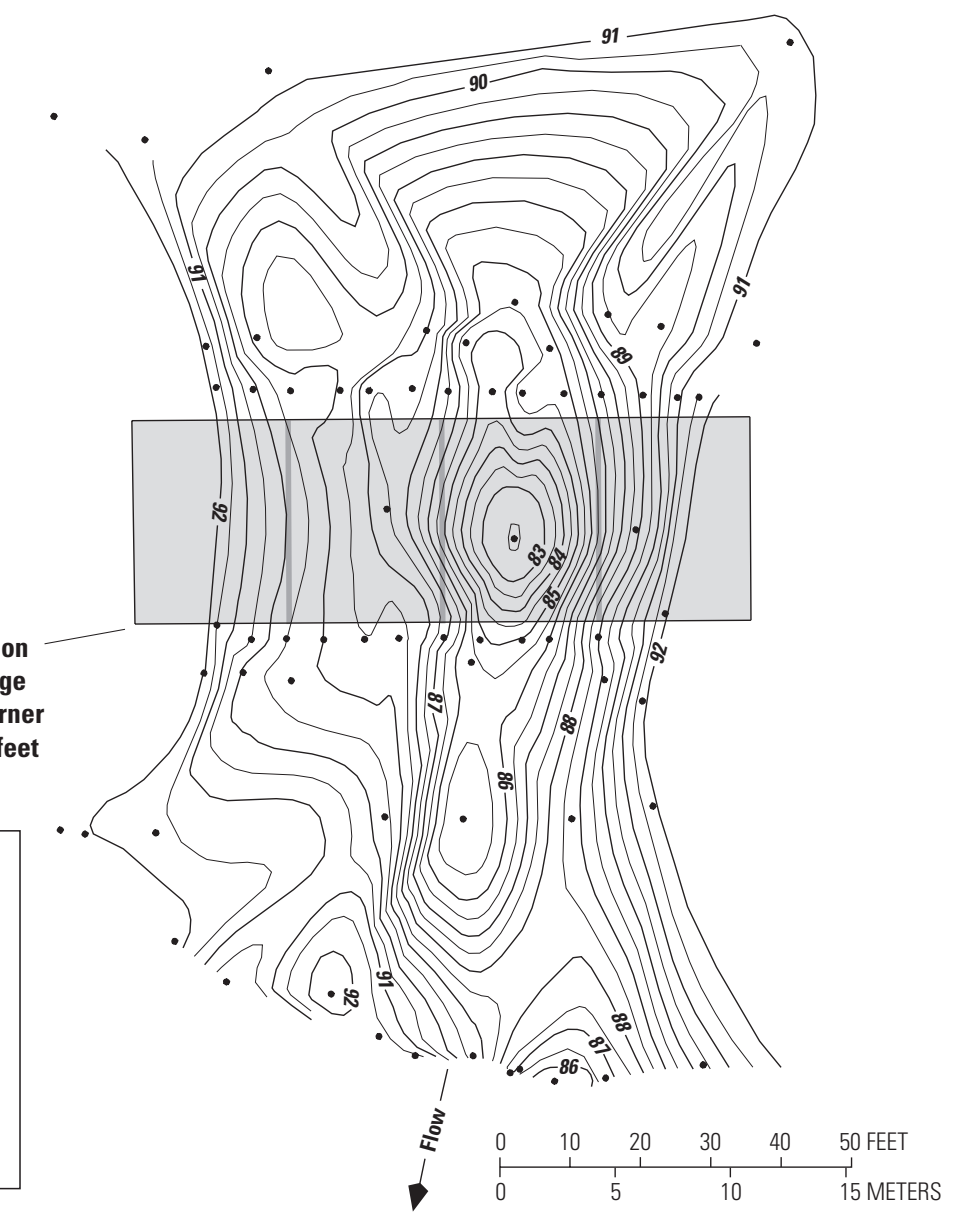

\begin{tabular}{|c|c|}
\hline & EXPLANATION \\
\hline & Bridge deck \\
\hline$-92-$ & $\begin{array}{l}\text { Topographic contour-Interval } \\
0.5 \text { foot. Arbitrary datum }\end{array}$ \\
\hline & Bent location \\
\hline - & Surveyed data point \\
\hline 91.9 & $\begin{array}{l}\text { Average unscoured reference- } \\
\text { surface elevation, in feet }\end{array}$ \\
\hline
\end{tabular}

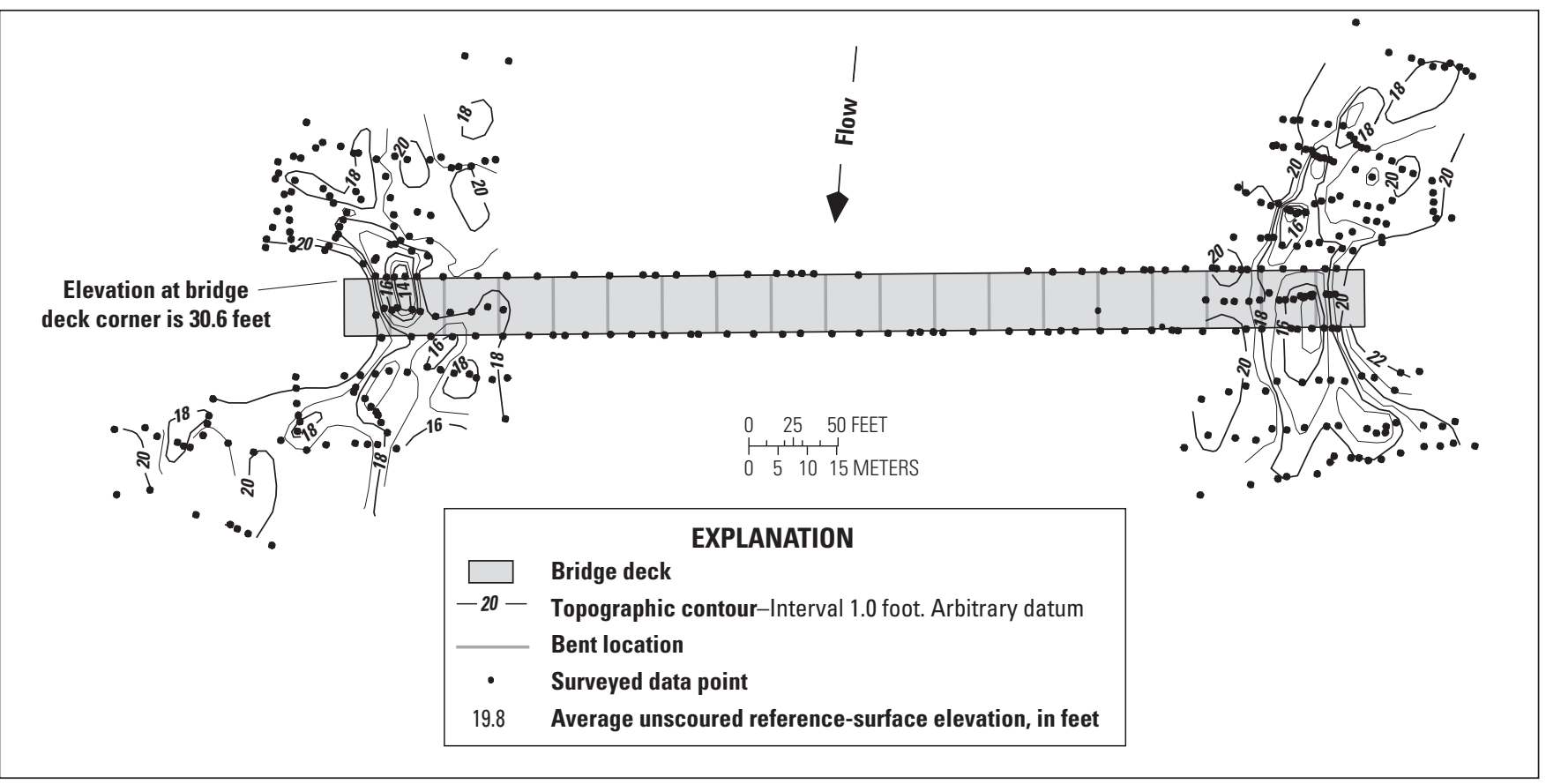

Figure 25. Example of separate left and right abutment-scour holes at longer bridges in the Coastal Plain, as shown at structure 277008700100 on Road S-87 crossing the Coosawhatchie River in Jasper County, South Carolina, November 12, 1997 (from Benedict, 2003). 


\section{Clear-Water Abutment-Scour Envelope Curves With Respect to Embankment Length}

As noted previously, various researchers concur with Dongol's (1993) conclusion, that "abutment length is one of the most important parameters influencing the process of local abutment scour." On the basis of this finding, Benedict (2003) used the South Carolina abutment-scour data (table 7) to develop several envelope curves that reflect the upper bound of clear-water abutment scour with respect to the embankment length blocking flow for the sampled bridges in South Carolina (figs. 26, 27). The embankment length blocking flow was evaluated with the WSPRO flow model (Shearman, 1990; Arneson and Shearman, 1998) for the 100-year flow condition by projecting the bridge cross section onto the upstream approach cross section and using the distance from the edge of the water to the projected abutment toe to represent the embankment length (fig. 28). (See report section "Guidance for Applying the South Carolina Bridge-Scour Envelope Curves" for additional information on evaluating the location of the approach cross section and the embankment length.) The WSPRO model generally uses the full flood plain width (left edge of water to right edge of water) for the natural, unconstricted approach cross section with no adjustment for ineffective flow areas, thus providing the largest justifiable estimate for embankment lengths. (Note: The bridge hydraulics algorithm and associated cross sections in the HEC-RAS model (Brunner, 2016) differ from that of the WSPRO model, and when using the HEC-RAS model to estimate the embankment length blocking flow, judgment must be used to assure that the estimates are comparable to those used in Benedict (2003), which were based on the WSPRO model. Guidance regarding this matter is presented in the report section "Guidance for Applying the South Carolina Bridge-Scour Envelope Curves.") Because of the distinct regional characteristics of the data collected in the Piedmont and Coastal Plain (table 7), separate envelope curves were developed for each region.

\section{Piedmont Clear-Water Abutment-Scour Envelope Curve}

The equation for the Piedmont abutment-scour envelope curve with respect to embankment length (fig. 26) is as follows:

$$
y_{s}=-0.000009 L^{2}+0.0276 L \text {, }
$$

where

$$
\begin{aligned}
& y_{s} \text { is the upper bound for potential abutment- } \\
& \text { scour depth, in feet; and } \\
& L \quad \text { is the embankment length blocking flow, } \\
& \text { in feet. }
\end{aligned}
$$

Because the largest observation of abutment scour in the Piedmont (18.0 ft) had an embankment length of $950 \mathrm{ft}$, Benedict (2003) recommended that the Piedmont envelope curve (fig. 26), as expressed in equation 13, be limited to sites with embankment lengths less than or equal to $950 \mathrm{ft}$. Additionally, the Piedmont embankment-length envelope curve (fig. 26) should not be used for evaluating abutment-scour potential at a multiple-bridge opening because of the uncertainty in

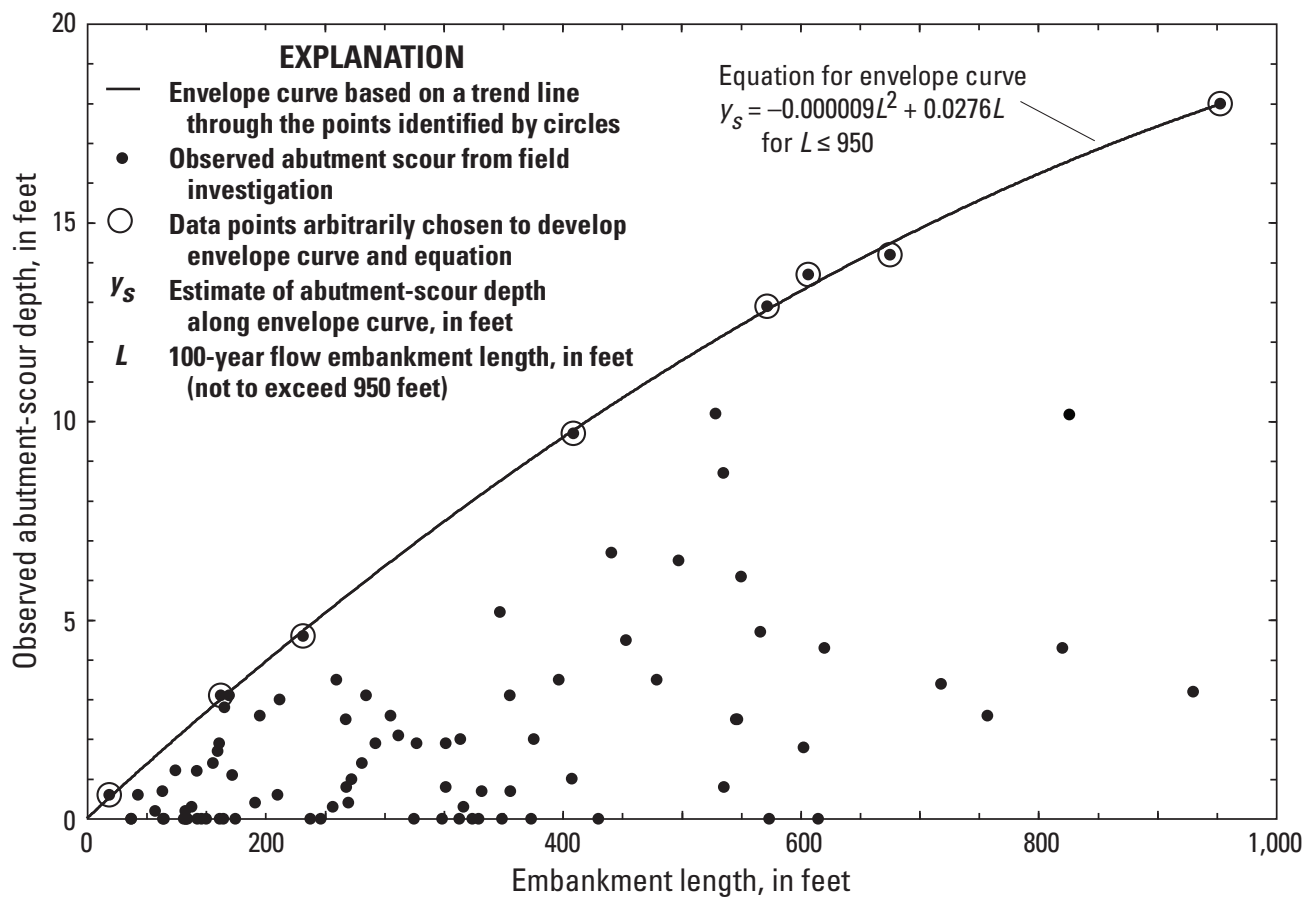

Figure 26. The South Carolina Piedmont clear-water abutment-scour envelope curve with respect to the embankment length blocking flow (from Benedict, 2003). 


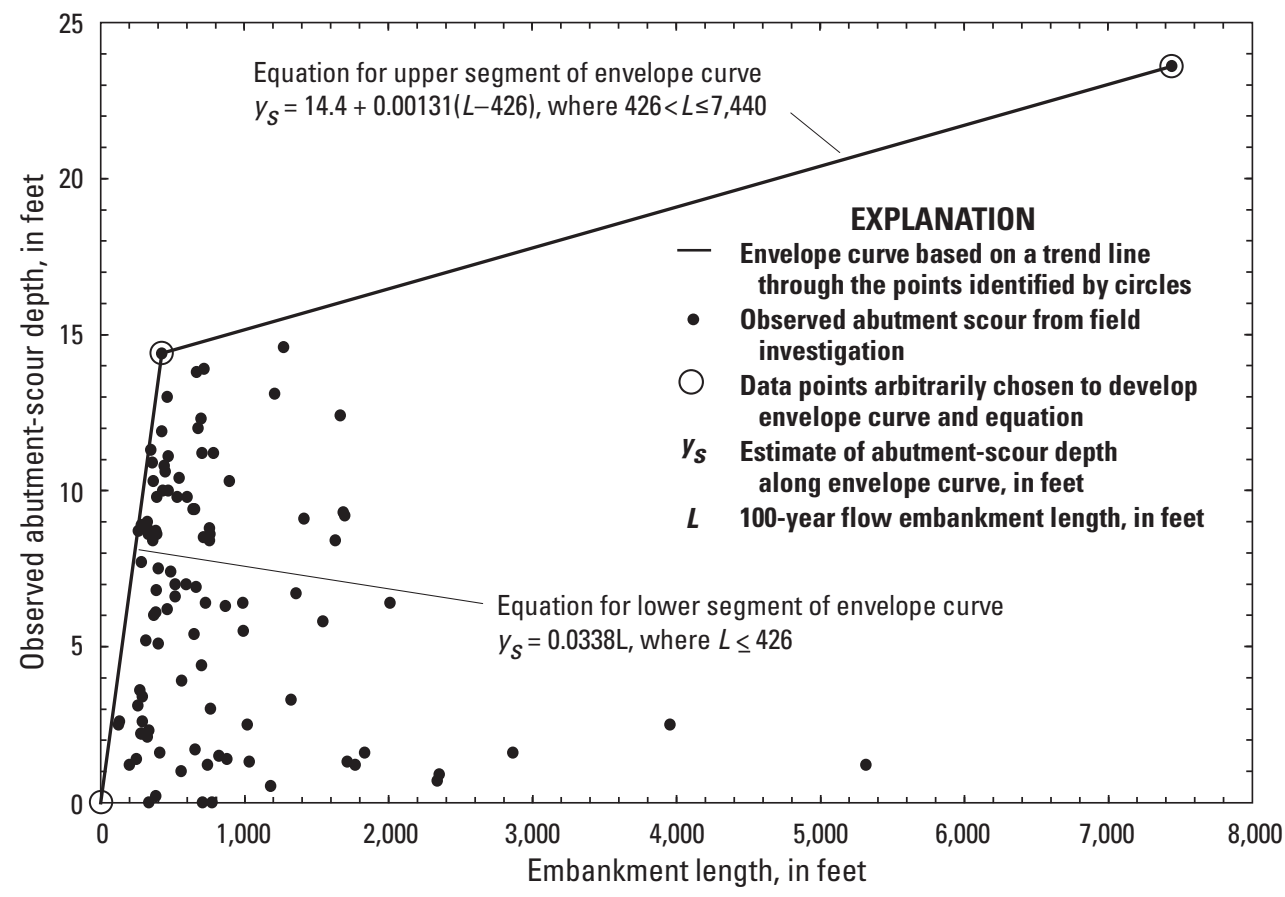

Figure 27. The South Carolina Coastal Plain clear-water abutment-scour envelope curve with respect to the embankment length blocking flow (from Benedict, 2003).

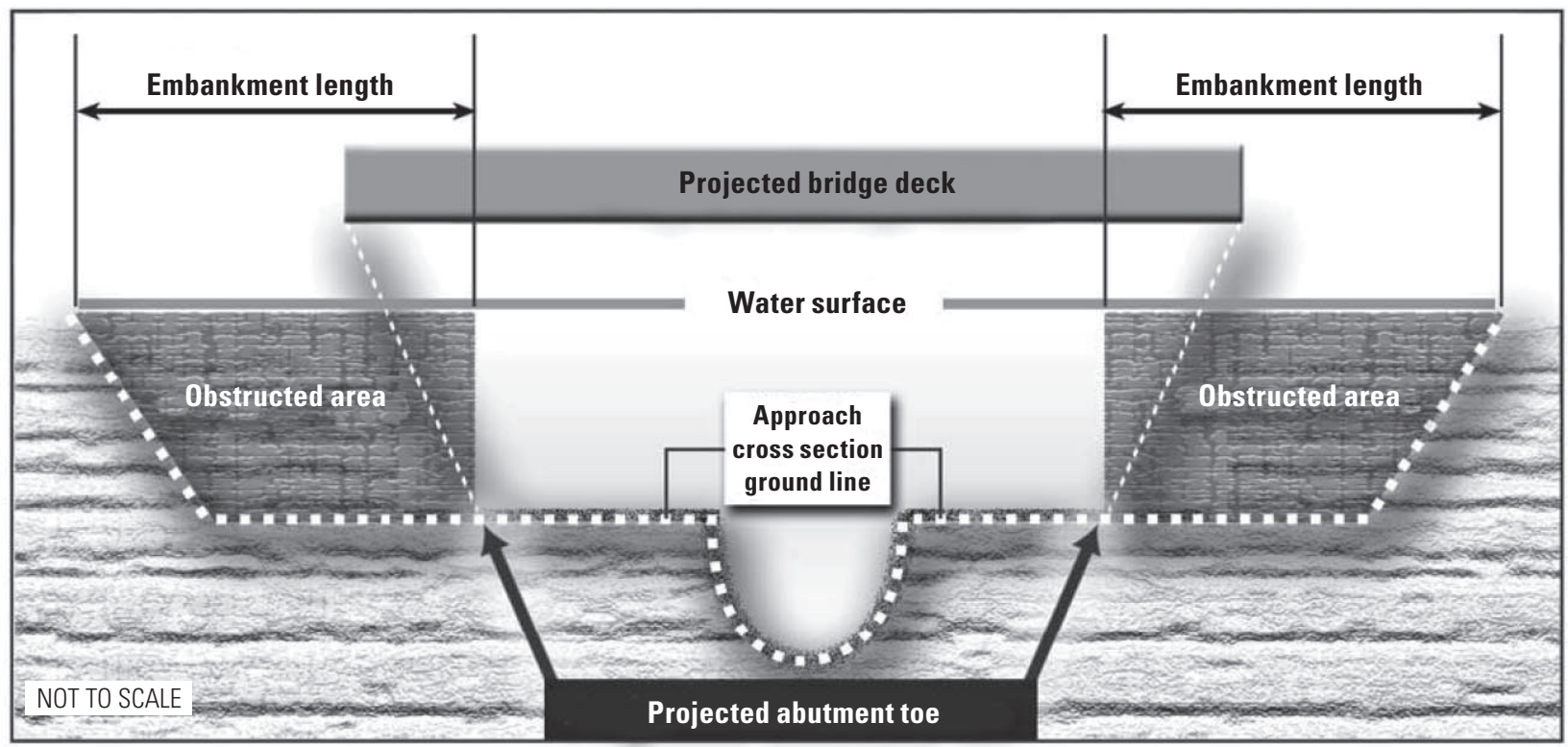

Figure 28. Definition of the embankment length blocking flow determined by projection of the bridge cross section onto the upstream approach cross section. 
determining the embankment length at such sites. Additional details regarding the development of the Piedmont abutmentscour envelope curve with respect to the embankment length can be found in Benedict (2003). Application and limitations of equation 13 are described in more detail in the report section "Application and Limitations of the South Carolina ClearWater Abutment-Scour Envelope Curves."

\section{Coastal Plain Clear-Water Abutment-Scour Envelope Curve}

The Coastal Plain clear-water abutment-scour envelope curve with respect to embankment length (fig. 27) is expressed in the following series of equations:

$$
\begin{gathered}
y_{s}=0.0338 L, \text { where } L \leq 426 \text {, and } \\
y_{s}=14.4+0.00131(L-426), \text { where } 426<L \leq 7,440,
\end{gathered}
$$

where all variables are as previously defined. Although the envelope curve as expressed in equation $14 \mathrm{~b}$ is limited to embankment lengths of 7,440 ft, the field data for embankment lengths exceeding 2,000 ft are sparse. Because of the sparse data, Benedict (2003) noted that the Coastal Plain abutment-scour envelope curve (fig. 27) may not fully represent the upper bound of abutment scour for embankment lengths greater than about 2,000 ft. Therefore, caution must be used when the embankment length exceeds this value. Additionally, the Coastal Plain embankment-length envelope curve (fig. 27) should not be used for evaluating abutment-scour potential at a multiple-bridge opening unless the embankment length for the abutment of interest exceeds $426 \mathrm{ft}$, which is the embankment length for which all of the Coastal Plain field data associated with multiple-bridge openings plotted within the envelope curve. Additional details regarding the development of the Coastal Plain abutment-scour envelope curve with respect to the embankment length can be found in Benedict (2003). Application and limitations of equations 14a and 14b are described in more detail in the report section "Application and Limitations of the South Carolina Clear-Water AbutmentScour Envelope Curves."

\section{Clear-Water Abutment-Scour Envelope Curves With Respect to the Geometric-Contraction Ratio}

As noted previously, various researchers have concluded that the degree of flow contraction created by the embankment length blocking flow is an important variable influencing abutment scour. Although the degree of flow contraction can be expressed as a ratio of the constricted to unconstricted flow, it also can be approximated by a geometric variable called the geometric-contraction ratio (fig. 29), expressed as

$$
m=1-b_{2} / B_{1} \text {, }
$$

where

$$
\begin{aligned}
& m \quad \text { is the geometric-contraction ratio; } \\
& b_{2} \quad \text { is the flow top width in the bridge } \\
& \text { opening, in feet; and } \\
& B_{1} \quad \text { is the flow top width at the upstream } \\
& \text { unconstricted approach cross section, } \\
& \text { in feet. }
\end{aligned}
$$

This approach was used by Das (1973) in his investigation of abutment scour. On the basis of the findings from other investigations, Benedict (2003) used the South Carolina abutment-scour data (table 7) to develop several envelope curves that reflect the upper bound of clear-water abutment scour with respect to the geometric-contraction ratio for the sampled bridges in South Carolina (figs. 30,31). Because of the distinct regional characteristics of the data collected in the Piedmont and Coastal Plain (table 7), separate envelope curves were developed for each region.

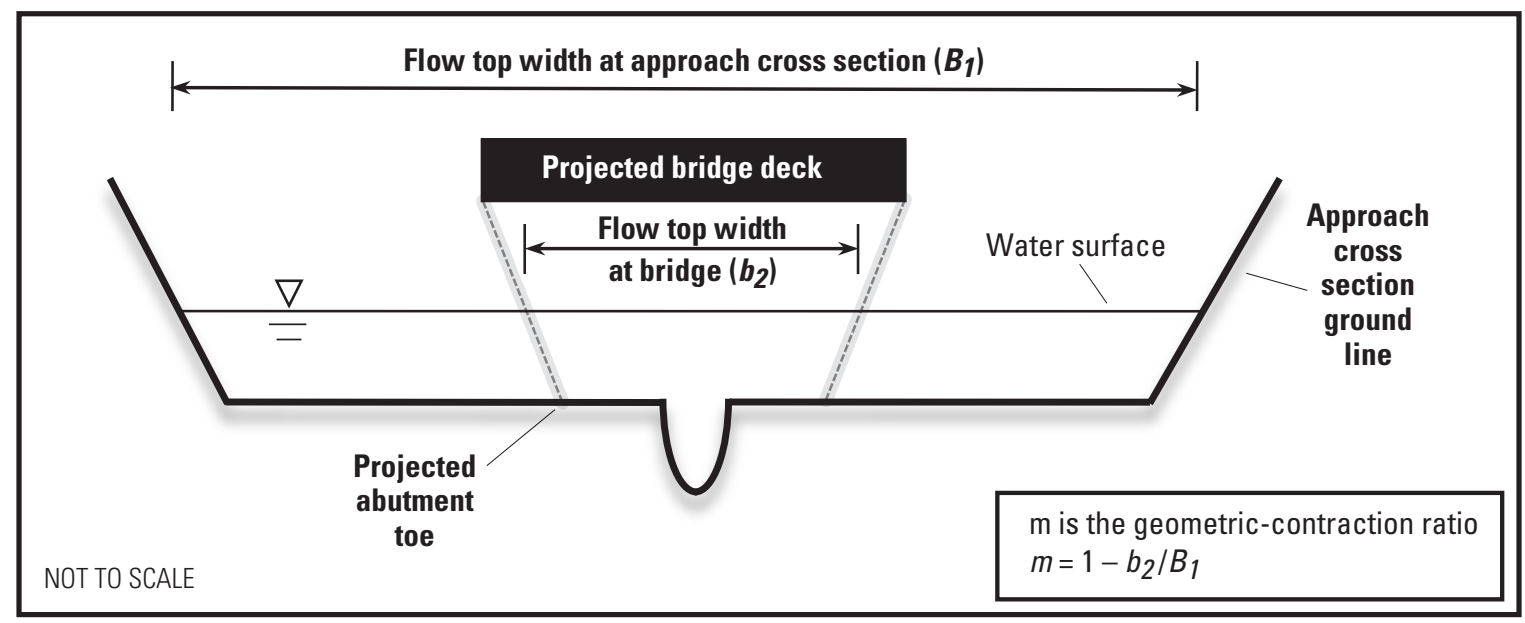

Figure 29. Definition of the geometric-contraction ratio. 


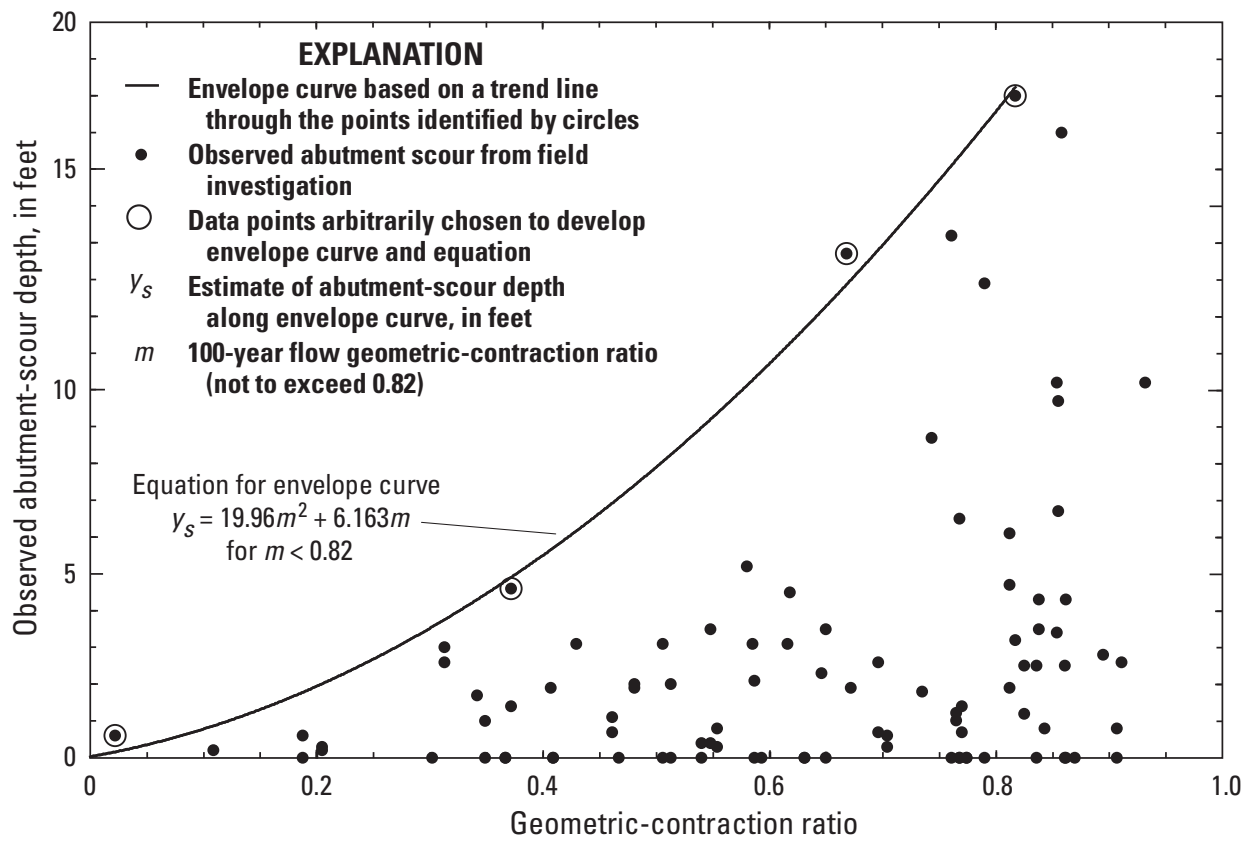

Figure 30. The South Carolina Piedmont clear-water abutment-scour envelope curve with respect to the geometric-contraction ratio (from Benedict, 2003).

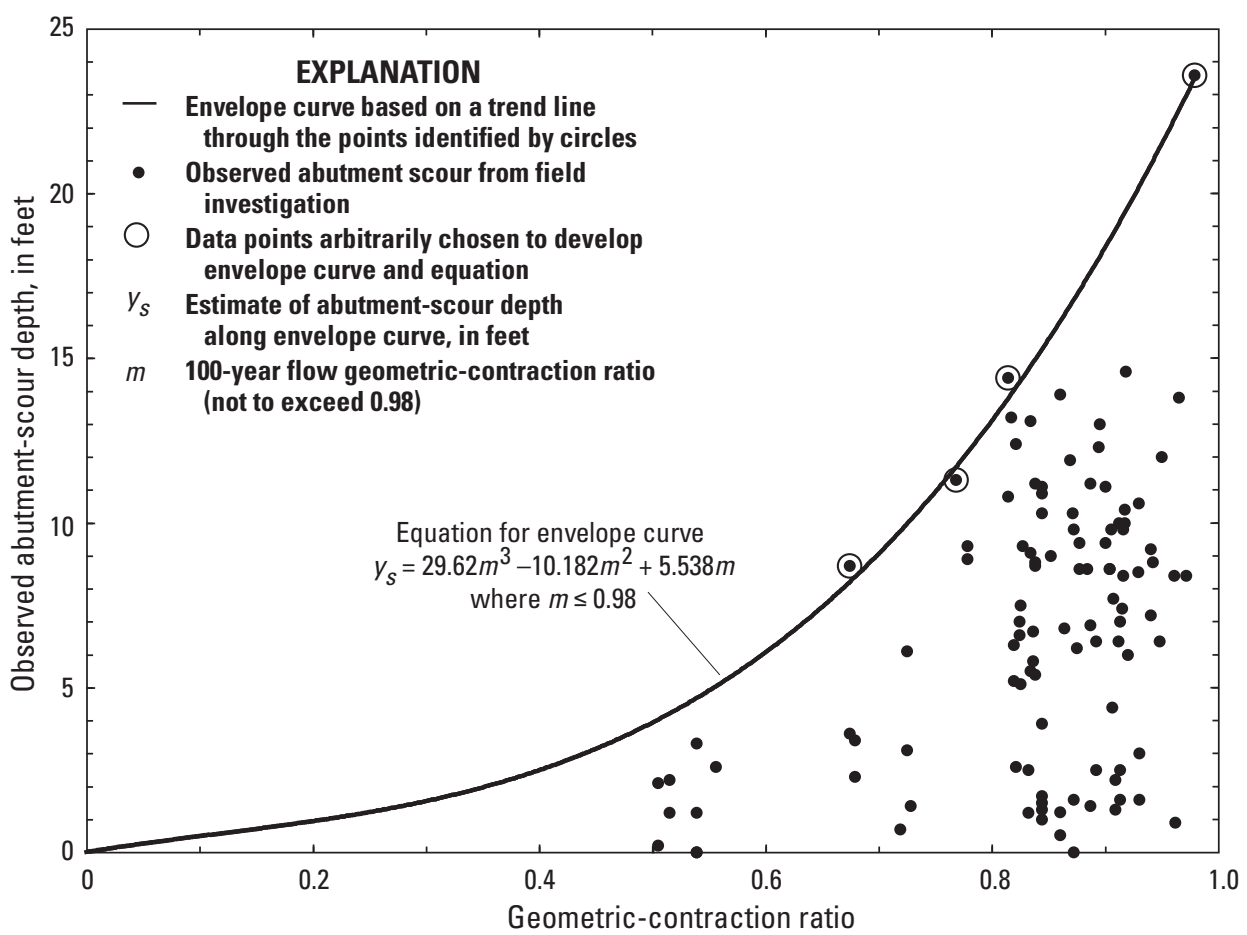

Figure 31. The South Carolina Coastal Plain clear-water abutment-scour envelope curve with respect to the geometric-contraction ratio (from Benedict, 2003). 
The geometric-contraction ratio was evaluated with the WSPRO flow model (Shearman, 1990; Arneson and Shearman, 1998) for the 100-year flow condition. To estimate the geometric-contraction ratio, the WSPRO model uses a standard location of the approach cross section at one bridge length upstream from the bridge. In WSPRO, the approach cross section represents the full, natural flood plain width with no adjustment for ineffective flow areas. (Note: The bridge hydraulics algorithm and associated cross sections in the HEC-RAS model (Brunner, 2016) differ from that of the WSPRO model, and when using the HEC-RAS model to estimate the geometriccontraction ratio, judgment must be used to assure that the estimates are comparable to those used in Benedict (2003), which were based on the WSPRO model. Guidance regarding this matter is presented in the report section "Guidance for Applying the South Carolina Bridge-Scour Envelope Curves.”)

\section{Piedmont Clear-Water Abutment-Scour Envelope Curve}

The equation for the Piedmont clear-water abutmentscour envelope curve (fig. 30) is as follows:

$$
y_{s}=19.96 m^{2}+6.163 m
$$

where $m$ is the geometric-contraction ratio, and other variables are as previously defined. Because the largest observation of abutment scour in the Piedmont (18.0 ft) had a geometriccontraction ratio of 0.82 , Benedict (2003) recommended that the Piedmont envelope curve (fig. 30), as expressed in equation 16 , be limited to sites with geometric-contraction ratios less than or equal to this value. Additional details regarding the development of the Piedmont abutment-scour envelope curve with respect to the geometric-contraction ratio can be found in Benedict (2003). Application and limitations of equation 16 are described in more detail in the report section "Application and Limitations of the South Carolina ClearWater Abutment-Scour Envelope Curves."

\section{Coastal Plain Clear-Water Abutment-Scour Envelope Curve}

The equation for the Coastal Plain clear-water abutmentscour envelope curve (fig. 31) is as follows:

$$
y_{s}=29.62 m^{3}-10.182 m^{2}+5.538 m
$$

where all variables are as previously defined, and $m$ is limited to values less than 0.98 . As previously noted, there are sparse data for embankment lengths greater than 2,000 ft. Although the Coastal Plain abutment-scour envelope curve with respect to the geometric-contraction ratio does not utilize embankment length, caution still should be used when evaluating scour potential at sites with embankment lengths exceeding that value. The largest observation of abutment scour in the
Coastal Plain (23.4 ft) had the largest geometric-contraction ratio of 0.98 , as well as the largest embankment length of $7,440 \mathrm{ft}$. Because these characteristics are at the upper bound for the Coastal Plain data, caution must be used when applying equation 17 to such severe contractions. Additional details regarding the development of the Coastal Plain abutmentscour envelope curve with respect to the geometric-contraction ratio can be found in Benedict (2003). Application and limitations of equation 17 are described in more detail in the report section "Application and Limitations of the South Carolina Clear-Water Abutment-Scour Envelope Curves."

\section{The Modified Clear-Water Abutment-Scour Envelope Curves}

Ballio and others (2009) conducted a limited investigation on the combined effect of embankment length and the geometriccontraction ratio on abutment-scour depth by conducting a series of experiments that held the embankment length constant while varying the geometric-contraction ratio. Findings from Ballio and others (2009) indicated that for geometric-contraction ratios of approximately 0.33 or less, the effect on local abutment-scour depth was negligible. For geometric-contraction ratios greater than 0.33 , however, local abutment-scour depth increased substantially. It is noteworthy that the upper bound of the South Carolina abutment-scour data (Benedict, 2003; figs. 30, 31 ) has similar patterns to the laboratory data, with relatively small abutment-scour depths for geometric-contraction ratios of approximately 0.4 or less and the upper bound of scour substantially increasing for larger values. This provides further confirmation that the patterns displayed in the field data are reasonable. On the basis of the work of Ballio and others (2009), Benedict and Caldwell (2012) modified the South Carolina abutment-scour envelope curves (Benedict, 2003) to include a family of envelope curves (secondary or modified envelope curves) that displays the combined effect of embankment length and the geometric-contraction ratio on abutment-scour depth. This was accomplished by grouping selected field data from South Carolina and the NBSD (table 8) into categories based on embankment-length and developing modified envelope curves for each embankment-length category. Examples of the modified envelope curves for selected embankment lengths and the associated field data for the Piedmont and Coastal Plain are shown in figure 32. The full family of curves for the Piedmont and Coastal Plain are shown in figures 33 and 34, respectively, and the equations for these curves are listed in table 9. The application of the modified abutment-scour envelope curves are limited to embankment lengths of $500 \mathrm{ft}$ or less and to geometric-contraction ratios less than or equal to 0.85 and 0.9 for the Piedmont and Coastal Plain, respectively. Additional details regarding the development of the South Carolina modified abutment-scour envelope curves can be found in Benedict and Caldwell (2012). Application and limitations of equations in table 9 are described in more detail in the report section "Application and Limitations of the South Carolina Clear-Water Abutment-Scour Envelope Curves." 
Table 8. Range of selected site characteristics for field measurements of abutment scour used to develop the modified clear-water abutment-scour envelope curves (from Benedict and Caldwell, 2012).

$\left[\mathrm{mi}^{2}\right.$, square mile; $\mathrm{ft} / \mathrm{ft}$, foot per foot; $\mathrm{ft} / \mathrm{s}$, foot per second; $\mathrm{ft}$, foot; $\mathrm{mm}$, millimeter; $<$, less than; —, not available]

\begin{tabular}{|c|c|c|c|c|c|c|c|c|}
\hline $\begin{array}{l}\text { Range } \\
\text { value }\end{array}$ & $\begin{array}{l}\text { Drainage } \\
\text { area } \\
\left(\mathrm{mi}^{2}\right)\end{array}$ & $\begin{array}{l}\text { Channel } \\
\text { slope } \\
\text { (ft/ft) }\end{array}$ & $\begin{array}{l}\text { Average } \\
\text { approach } \\
\text { velocity } \\
\text { (ft/s) }\end{array}$ & $\begin{array}{c}{ }^{\text {aAverage }} \\
\text { approach } \\
\text { flow depth } \\
\text { (ft) }\end{array}$ & $\begin{array}{l}\text { Embankment } \\
\text { length block- } \\
\text { ing flow } \\
\text { (ft) }\end{array}$ & $\begin{array}{c}\text { Geometric } \\
\text { contraction } \\
\text { ratio }\end{array}$ & $\begin{array}{l}\text { Median } \\
\text { grain size } \\
(\mathrm{mm})\end{array}$ & $\begin{array}{l}\text { Measured } \\
\text { scour } \\
\text { depth } \\
\text { (ft) }\end{array}$ \\
\hline \multicolumn{9}{|c|}{ South Carolina Piedmont (Benedict, 2003) (74 measurements) } \\
\hline Minimum & 11 & 0.0004 & 0.14 & 1.0 & 18 & 0.02 & $<0.062$ & 0 \\
\hline Median & 76 & 0.0012 & 0.92 & 5.1 & 208 & 0.59 & 0.095 & 0.7 \\
\hline \multicolumn{9}{|c|}{ South Carolina Coastal Plain (Benedict, 2003) (39 measurements) } \\
\hline Minimum & 6 & 0.0002 & 0.2 & 1.5 & 127 & 0.56 & $<0.062$ & 1.4 \\
\hline Median & 43 & 0.00076 & 0.5 & 4.5 & 374 & 0.86 & 0.21 & 8.6 \\
\hline Maximum & 426 & 0.0024 & 1.57 & 7.1 & 489 & 1 & 0.78 & 14.4 \\
\hline Maximum & 1,963 & 0.0046 & - & - & 546 & 0.93 & $35.0^{\mathrm{a}}$ & 10 \\
\hline
\end{tabular}

${ }^{a}$ Data missing for seven measurements.

Table 9. Equations for the modified clear-water abutment-scour envelope curves in the Piedmont and Coastal Plain of South Carolina (from Benedict and Caldwell, 2012).

[Note: If the geometric-contraction ratio for a given bridge is less than the minimum value, the minimum value should be used in the equation. $\mathrm{ft}$, foot; $\leq$, less than or equal to; $L$, embankment length; $y_{s}$, scour depth, in feet; $m$, geometriccontraction ratio; $<$, less than]

\begin{tabular}{ccc}
$\begin{array}{c}\text { Embankment-length } \\
\text { category }\end{array}$ & \multicolumn{1}{c}{ Equation } & $\begin{array}{c}\text { Limits of the geometric- } \\
\text { contraction ratio }\end{array}$ \\
\hline $0 \mathrm{ft} \leq L \leq 100 \mathrm{ft}$ & $y_{s}=3.27 m^{2}-1.12 m+1.29$ & $0.136 \leq m \leq 0.85$ \\
$100 \mathrm{ft}<L \leq 200 \mathrm{ft}$ & $y_{s}=6.27 m^{2}-2.83 m+3.16$ & $0.255 \leq m \leq 0.85$ \\
$200 \mathrm{ft}<L \leq 300 \mathrm{ft}$ & $y_{s}=8.33 m^{2}-4.06 m+4.84$ & $0.343 \leq m \leq 0.85$ \\
$300 \mathrm{ft}<L \leq 400 \mathrm{ft}$ & $y_{s}=11.54 m^{2}-6.78 m+6.93$ & $0.423 \leq m \leq 0.85$ \\
$400 \mathrm{ft}<L \leq 500 \mathrm{ft}$ & $y_{s}=15.38 m^{2}-10.83 m+9.61$ & $0.503 \leq m \leq 0.85$ \\
\hline $0 \mathrm{ft} \leq L \leq 100 \mathrm{ft}$ & Coastal Plain & \\
\hline $100 \mathrm{ft}<L \leq 200 \mathrm{ft}$ & $y_{s}=4.64 m^{2}-1.99 m+1.43$ & $0.252 \leq m \leq 0.9$ \\
$200 \mathrm{ft}<L \leq 300 \mathrm{ft}$ & $y_{s}=9.12 m^{2}-5.55 m+4.37$ & $0.496 \leq m \leq 0.9$ \\
$300 \mathrm{ft}<L \leq 400 \mathrm{ft}$ & $y_{s}=13.14 m^{2}-9.57 m+8.07$ & $0.649 \leq m \leq 0.9$ \\
$400 \mathrm{ft}<L \leq 500 \mathrm{ft}$ & $y_{s}=21.30 m^{2}-19.22 m+13.54$ & $0.757 \leq m \leq 0.9$ \\
\hline
\end{tabular}



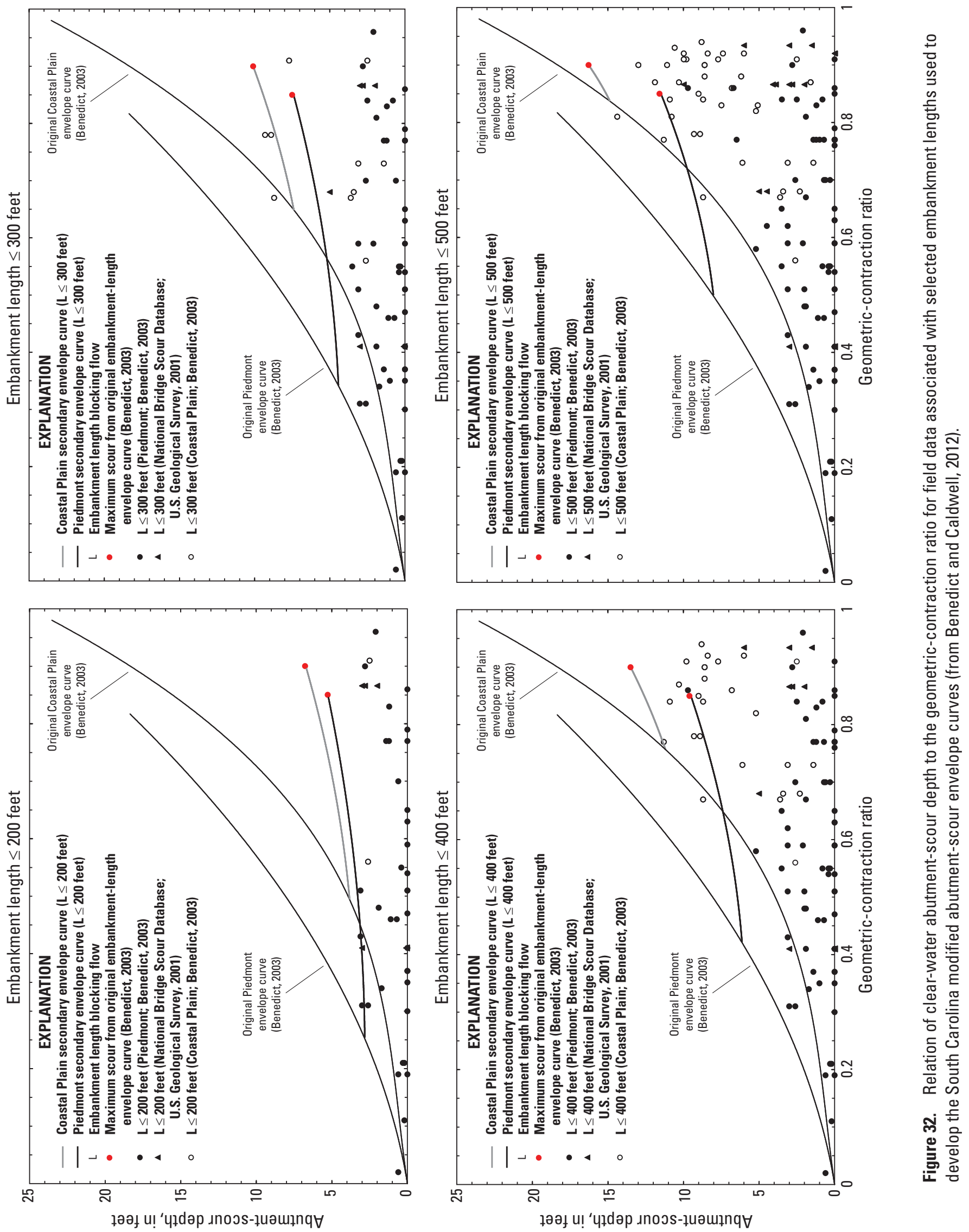


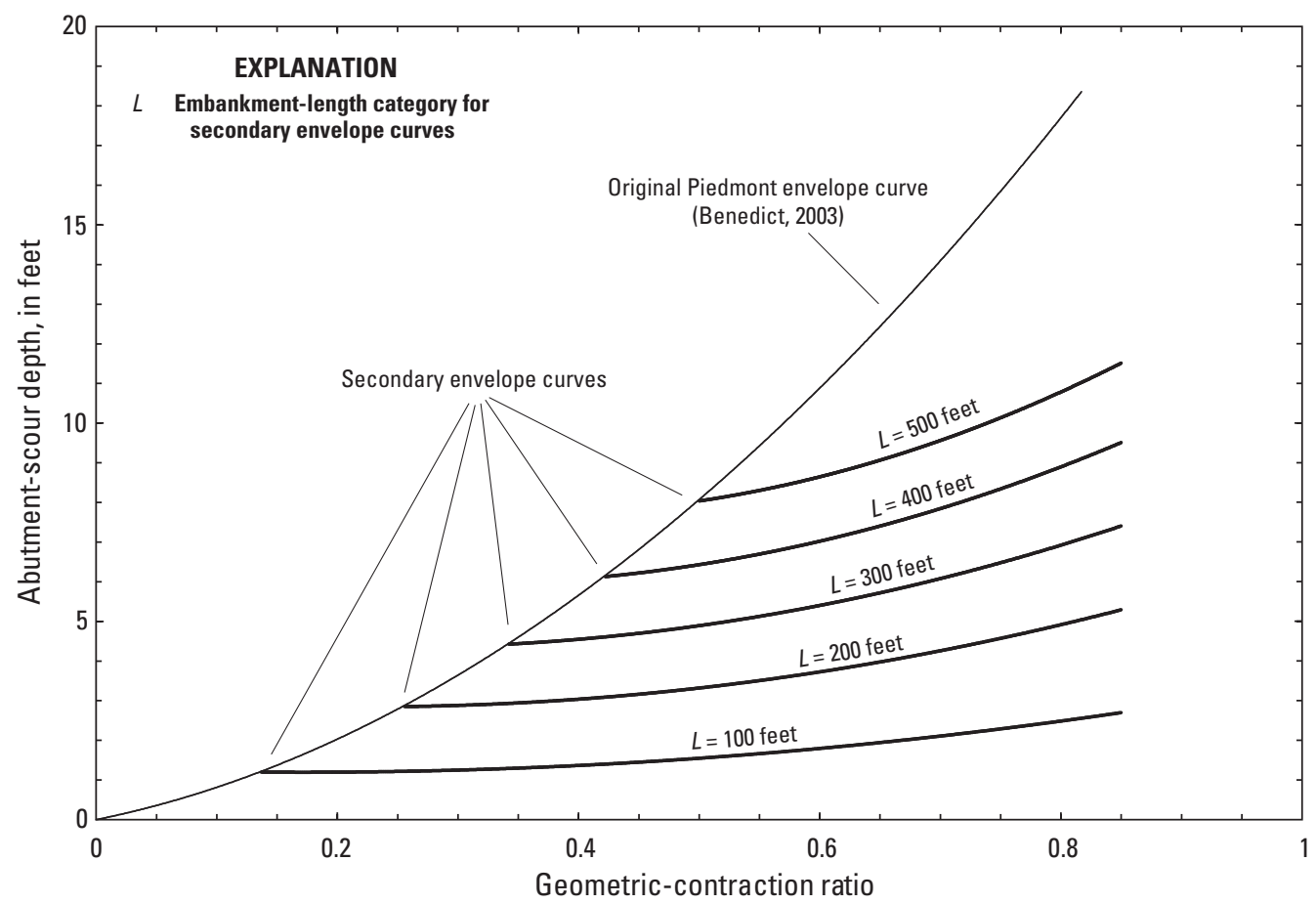

Figure 33. Relation of clear-water abutment-scour depth to the geometric-contraction ratio for selected categories of embankment lengths in the Piedmont of South Carolina (from Benedict and Caldwell, 2012).

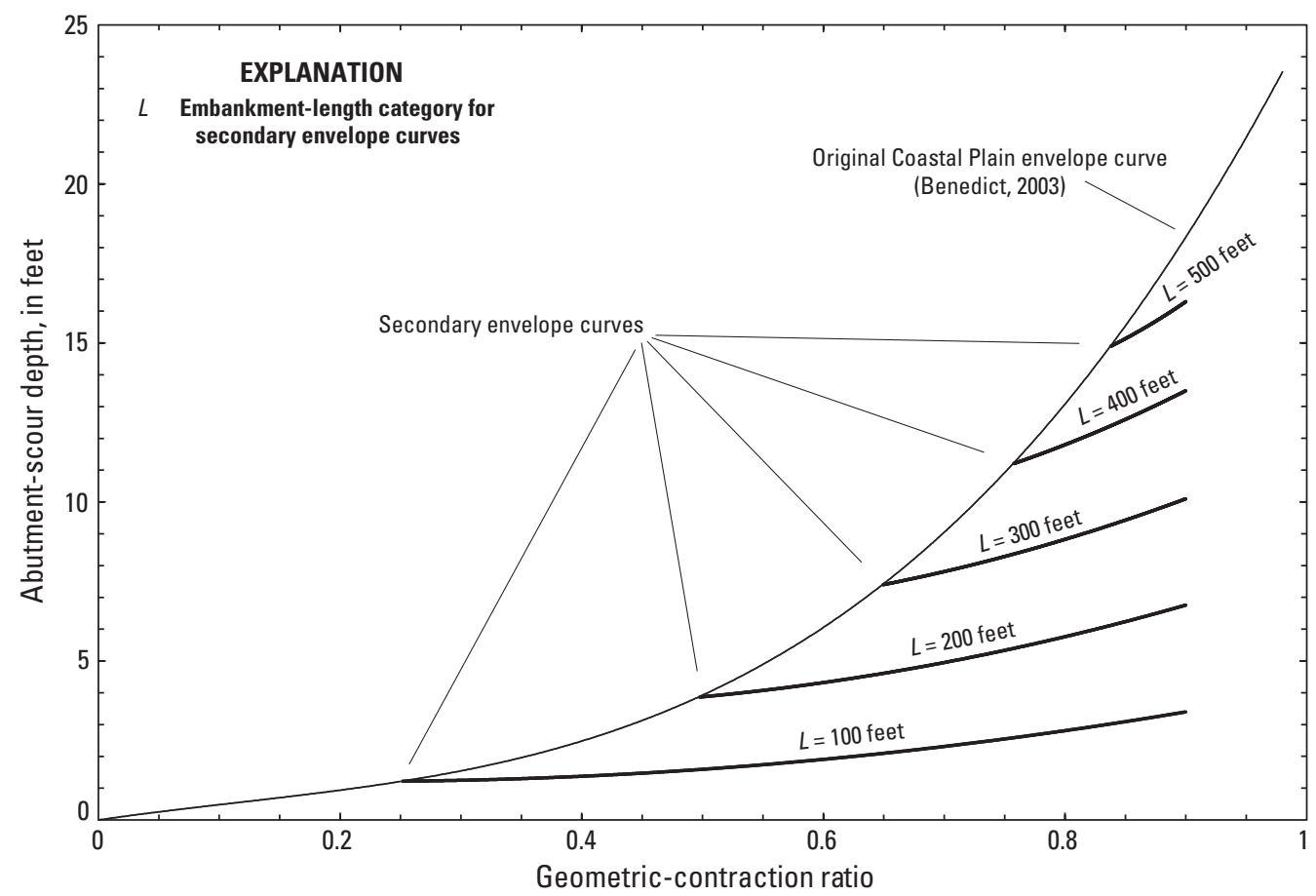

Figure 34. Relation of clear-water abutment-scour depth to the geometric-contraction ratio for selected categories of embankment lengths in the Coastal Plain of South Carolina (from Benedict and Caldwell, 2012). 


\section{Comparison of the South Carolina Clear-Water Abutment-Scour Envelope Curves With Other Data}

Benedict (2003) and Benedict and Caldwell (2012) made some limited comparisons of the South Carolina abutmentscour data with selected laboratory and field data from other sources. To expand upon this previous work, Benedict (2016) compiled additional laboratory and field data from other existing sources and compared the upper-bound patterns of those data to the South Carolina data. The compiled laboratory data consisted of 446 selected measurements as given in table 10 . These data primarily represent clear-water scour conditions with unskewed abutments and a variety of abutment shapes. The laboratory flumes included simple rectangular channels for the data published in or prior to 1993 and primarily compound channels for the other data. The compiled laboratory data have a wide range of hydraulic, sediment and abutment geometry characteristics (table 10), providing a good dataset for assessing the upper bound of abutment scour in the laboratory setting. Additional details about the laboratory abutment-scour data can be found in Benedict (2016) and the cited sources.

The compiled field data are listed in table 11 and include 133 measurements: 93 measurements from the small, steep-gradient, coarse sediment streams of Maine (Lombard and Hodgkins, 2008), 23 from the low-gradient, cohesive sediment streams of the Alabama Black Prairie Belt (Lee and Hedgecock, 2008), 15 from the NBSD (U.S. Geological Survey, 2001), and 2 from the Missouri River at Interstate 70 (I-70; Parola and others, 1998). (Note: Seven of the NBSD scour measurements are associated with meandering streams that are challenging to simulate with a one-dimensional flow model. These models were reviewed and modified, where appropriate, to better represent the unconstricted approach section. This adjustment caused some of the

Table 10. Range of characteristics for selected laboratory abutment-scour data (from Benedict, 2016).

[ft/s, foot per second; ft, foot; mm, millimeter; $D_{\text {sadj }}$, abutment-scour depth adjusted for abutment shape and skew; — , not available]

\begin{tabular}{|c|c|c|c|c|c|c|c|c|}
\hline $\begin{array}{l}\text { Range } \\
\text { value }\end{array}$ & $\begin{array}{c}\text { Average } \\
\text { approach } \\
\text { velocity } \\
\text { (ft/s) }\end{array}$ & $\begin{array}{c}\text { average } \\
\text { approach } \\
\text { flow depth }(y) \\
\text { (ft) }\end{array}$ & $\begin{array}{l}\text { Embankment } \\
\text { length } \\
\text { blocking } \\
\text { flow (L) } \\
\text { (ft) }\end{array}$ & $\begin{array}{l}\text { Median } \\
\text { grain size } \\
(\mathrm{mm})\end{array}$ & $\begin{array}{c}\text { Measured } \\
\text { scour } \\
\text { depth }\left(D_{s}\right) \\
\text { (ft) }\end{array}$ & $\begin{array}{c}\text { Relative } \\
\text { abutment } \\
\text { length } \\
(L / y)\end{array}$ & $\begin{array}{c}\text { Relative } \\
\text { scour depth } \\
\left(D_{\text {sadj }} / y\right)\end{array}$ & $\begin{array}{c}\text { Geometric } \\
\text { contraction } \\
\text { ratio } \\
(m)\end{array}$ \\
\hline \multicolumn{9}{|c|}{ Melville (1992) (96 measurements) } \\
\hline Minimum & - & 0.07 & 0.3 & - & 0.3 & 0.25 & 0.5 & - \\
\hline Maximum & - & 1.97 & 4.6 & - & 2.4 & 69 & 9.7 & - \\
\hline \multicolumn{9}{|c|}{ Palaviccini (1993) (191 measurements) } \\
\hline Minimum & 0.31 & 0.09 & 0.2 & 0.29 & 0.0 & 0.41 & 0.01 & 0.1 \\
\hline Median & 1.02 & 0.4 & 1 & 0.9 & 0.4 & 3.43 & 2.07 & 0.27 \\
\hline Median & 1.23 & 0.11 & 6.9 & 3.3 & 0.6 & 54.1 & 5.04 & 0.5 \\
\hline Maximum & 2.04 & 0.19 & 12 & 3.3 & 1 & 162 & 11 & 0.87 \\
\hline \multicolumn{9}{|c|}{${ }^{\mathrm{b} B r i a u d}$ and others (2009) (17 measurements) } \\
\hline Minimum & 0.68 & 0.6 & 3.3 & 0.004 & 0.2 & 2.77 & 0.24 & 0.28 \\
\hline Median & 1.34 & 0.96 & 6 & 0.004 & 1.4 & 6.22 & 3.02 & 0.5 \\
\hline Maximum & 1.9 & 1.31 & 9 & 0.004 & 4.7 & 10 & 9.09 & 0.75 \\
\hline \multicolumn{9}{|c|}{ Ettema and others (2010) (62 measurements) } \\
\hline Minimum & 1.08 & 0.49 & 1.1 & 0.45 & 0.2 & 2.15 & 0.81 & 0.08 \\
\hline
\end{tabular}

${ }^{\text {a}}$ For setback abutments on the flood plain, flow depth is the average approach flood plain flow depth. For abutments set at the channel bank or protruding into the channel, flow depth is the average approach channel flow depth.

bediments for this investigation were cohesive clays. 
Table 11. Range of characteristics for selected abutment-scour measurements from Maine, Alabama, the National Bridge Scour Database, and the Missouri River Interstate-70 Bridge (from Benedict, 2016).

$\left[\mathrm{mi}^{2}\right.$, square mile; $\mathrm{ft} / \mathrm{ft}$, foot per foot; $\mathrm{ft} / \mathrm{s}$, foot per second; $\mathrm{ft}$, foot; $\mathrm{mm}$, millimeter; $D_{\text {sadj }}$, abutment-scour depth adjusted for abutment shape and skew; -, not available]

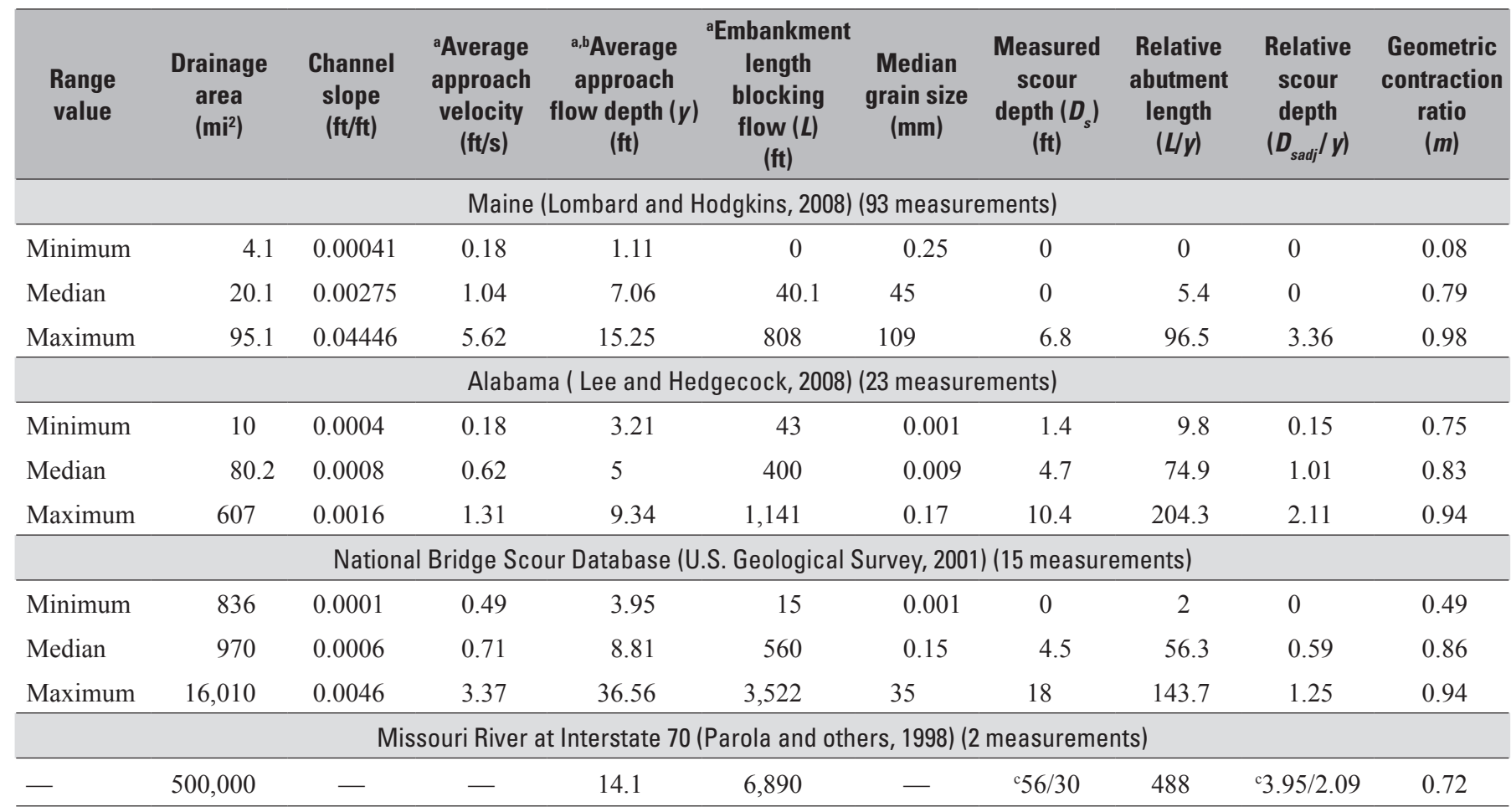

${ }^{a}$ Values were generally estimated from a one-dimensional water-surface profile model.

${ }^{b}$ For setback abutments on the flood plain, flow depth is the average approach flood plain flow depth. For abutments set at the channel bank or protruding into the channel, flow depth is the average approach channel flow depth.

${ }^{c}$ Two scour measurements were made at this site: the first value represents the measurement at the levee breach approximately 350 feet upstream from the bridge and the second value is at the bridge.

hydraulic properties to vary from those originally published in the NBSD.) The NBSD data primarily have spill-through abutments, and the Maine and Alabama data primarily have wing-wall abutments. The NBSD and Maine data are primarily bankline abutments or abutments that protrude into the main channel, while the Alabama data are primarily flood plain relief bridges. The Alabama data were originally classified as contraction scour (Lee and Hedgecock, 2008); however, they are similar to the relief bridges in the South Carolina abutment-scour investigation (Benedict, 2003), making it appropriate to classify the data as abutment scour. All of the Alabama and many of the Maine data represent clear-water scour conditions, while most of the NBSD data represent live-bed scour conditions. Most of these data represent historical scour measurements similar to the South Carolina data, and one-dimensional flow models were used to estimate the hydraulic properties. The post-flood nature of the scour measurements, in conjunction with the estimated hydraulics, makes these data less than ideal. These limitations should be kept in mind when using these field data in any analysis.

The two scour measurements at the I-70 crossing the Missouri River, are associated with the 1993 flood and are perhaps the largest measured riverine abutment-scour depths in the United States (30 ft at the bridge and $56 \mathrm{ft}$ upstream from the bridge) and were influenced by a levee breach located approximately $350 \mathrm{ft}$ upstream from the abutment. Additionally, the site has a large drainage area of 500,000 $\mathrm{mi}^{2}$ that produces long flood-flow durations and, therefore, a larger potential for scour. In contrast, the maximum drainage area for the South Carolina data is $8,830 \mathrm{mi}^{2}$ with a median value less than $100 \mathrm{mi}^{2}$. The adverse flow conditions and substantially larger drainage area of the Missouri River site contribute to the larger scour depths than those of the South Carolina data. Although the Missouri River data do not represent typical abutment scour, they were included in the analysis for perspective. Additional details about the field data can be found in Benedict (2016) and the cited sources. 


\section{Comparison of the Clear-Water Abutment-Scour Field Data to Laboratory Data}

Benedict (2016) compared the laboratory and field data using dimensionless relations, and a summary of the analysis and findings follows. Melville (1992) used 96 laboratory measurements (table 10), collected in rectangular channels at threshold clear-water scour conditions, to develop an envelope curve of abutment scour (fig. 35) based on the relation of relative scour depth $\left(y_{\text {sadj }} / y\right)$ to relative abutment length $(L / y)$, where $y_{\text {sadj }}$ is the measured abutment-scour depth adjusted for the effect of abutment shape, $y$ is the approach flow depth, and $L$ is the embankment length blocking flow. The adjusted scour depth represents the equivalent scour depth associated with the abutment shape of a vertical wall and is obtained by dividing the measured scour depth by the appropriate abutment shape correction factors as described in Melville (1992). Melville (1992) noted that the upper bound of $y_{\text {sadj }} / y$ increased with increasing $L / y$ and identified three abutmentlength categories where the rate at which scour increased varied. These categories, as identified in figure 35 , included short abutments $(L / y \leq 1)$ with the smallest scour potential, long abutments $(L / y \geq 25)$ with the largest scour potential, and intermediate abutments between these values. The other laboratory data listed in table 10 were adjusted in a manner similar to the Melville (1992) data and also are shown in figure 35. All of the laboratory data fall within or close to the Melville (1992) envelope curve, indicating that the envelope curve is a reasonable representation of the approximate upper bound of abutment scour for laboratory data. Additionally, the data shown in figure 35 confirm the general pattern that the potential for abutment-scour depth increases at a decreasing rate as the embankment length increases. It also is noteworthy that the maximum scour depth based on the envelope curve in figure 35 is about 10 times the approach flow depth.

The South Carolina field data (table 7) and the field data from table 11 were adjusted for abutment shape and skew similar to the manner of the Melville (1992) laboratory data and plotted with the previously presented laboratory envelope curve (fig. 36). The Melville (1992) laboratory data were included in the figure to provide perspective between the laboratory and field data patterns. Benedict (2016) developed approximate field envelope curves for both non-cohesive and cohesive sediments as shown in figure 36 . The field data encompass the range of the three abutment-length categories; however, the data are heavily weighted toward the longabutment category, where scour potential is greatest, with few short abutments. The Missouri River measurements are the largest scour depths for the field data and are associated with prolonged flood flows and adverse field conditions (levee breach) that tend to create severe scour. These data fall in close proximity to the upper bound of the South Carolina data, providing a measure of confidence that the South Carolina data are reasonable. The field envelope curve for cohesive sediments encompasses all of the cohesive data from the South Carolina Piedmont and Alabama. These data had varying degrees of cohesion, with the less cohesive sediments tending to have larger scour depths that fall near the envelope curve while the more scour-resistant cohesive sediments can be substantially below the envelope curve. The upper bound of the non-cohesive field data is 4.25 times the approach flow depth with the cohesive field data having a value of three times the approach flow depth.

\section{Discrepancies in the Upper Bound of the Clear- Water Abutment-Scour Laboratory and Field Data}

Figure 36 highlights the distinct difference in the upper bounds of relative scour for the laboratory and field data, with the maximum relative abutment-scour depth for the laboratory data being 11 in contrast to 4.25 for the field data. The maximum relative abutment-scour depth is the measured abutment-scour depth adjusted for the effect of abutment shape $\left(y_{\text {sadj }}\right)$ divided by the approach flow depth $(y)$. Benedict (2016) noted that this large discrepancy is likely caused by the oversimplification of the laboratory models in contrast to the complexity of the field. In particular, the small to moderate drainage areas associated with most of the field data (tables 7,11) will tend to have peak-flow durations lasting only hours (Benedict, 2003), thus preventing the attainment of equilibrium abutment-scour depths similar to those associated with laboratory investigations that often run for days (Sturm, 2004). Additionally, the sediments in the field are non-uniform in grain size and often have some measure of cohesion. This is particularly the case for flood plain sediments that consist of varying mixtures of clays, silts, and sands, along with organic matter, and this is undoubtedly why the upper bound of the South Carolina Piedmont and Alabama data, generally having cohesive sediments, are smaller than the non-cohesive data. Furthermore, sediment characteristics typically change with depth, often becoming more resistant to scour and thus limiting scour depth. It is common to see abutment-scour holes cut through the more erodible alluvium sediments on a flood plain and then encounter a subsurface, scour-resistant sediment that impedes or limits scour. This was the pattern seen in the deeper scour holes in the South Carolina data (Benedict, 2003). Similarly, this was the pattern for the scour hole at I-70 crossing the Missouri River (Parola and others, 1998). These field patterns indicate that scour-resistant subsurface sediments will frequently impede or limit scour and highlights the importance of understanding the sediment characteristics and subsurface strata at a site to gain insights regarding scour potential. 


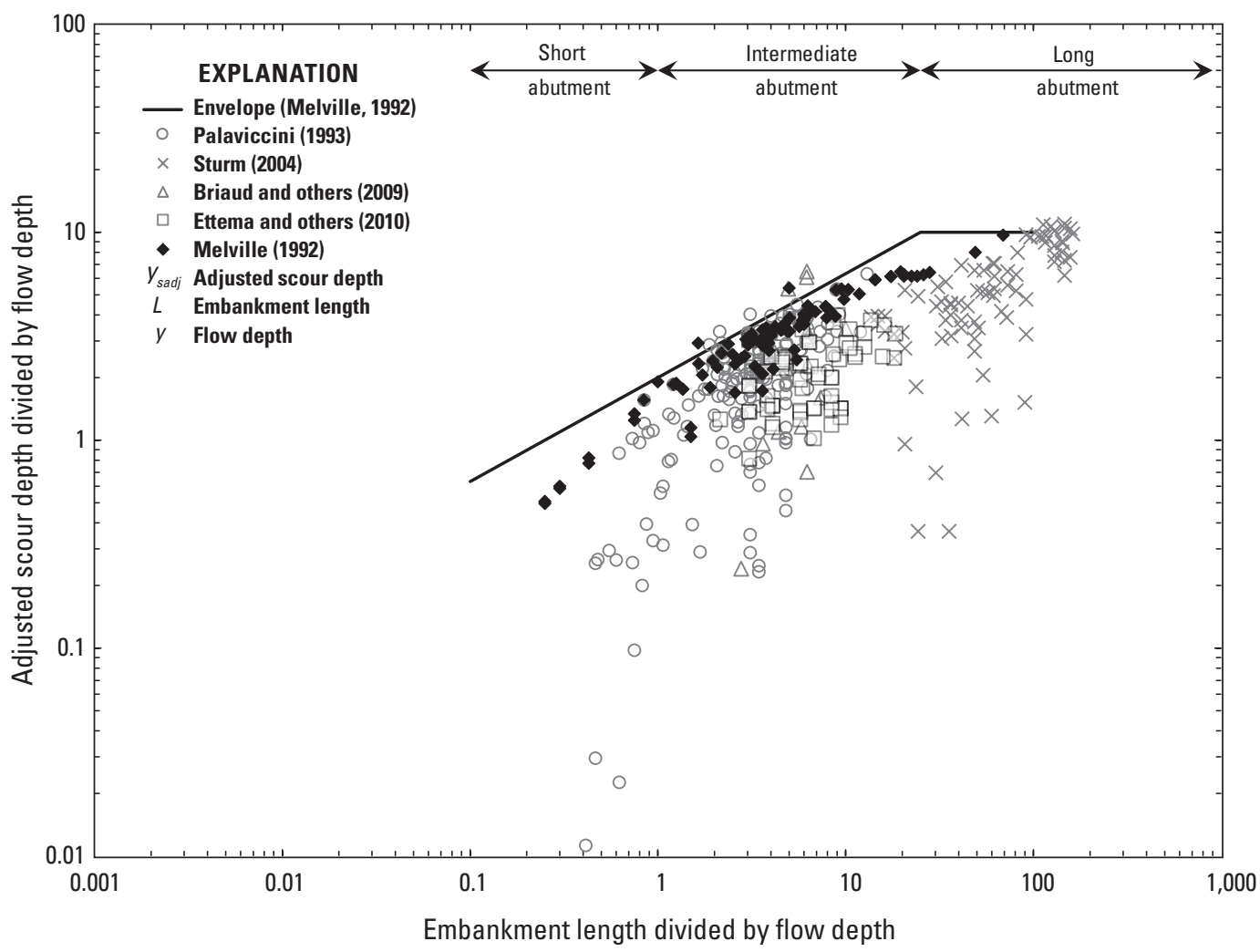

Figure 35. Relation of the relative abutment-scour depth $\left(y_{\text {sadj }} / y\right)$ to relative abutment length $(L / y)$ for selected laboratory data (from Benedict, 2016).

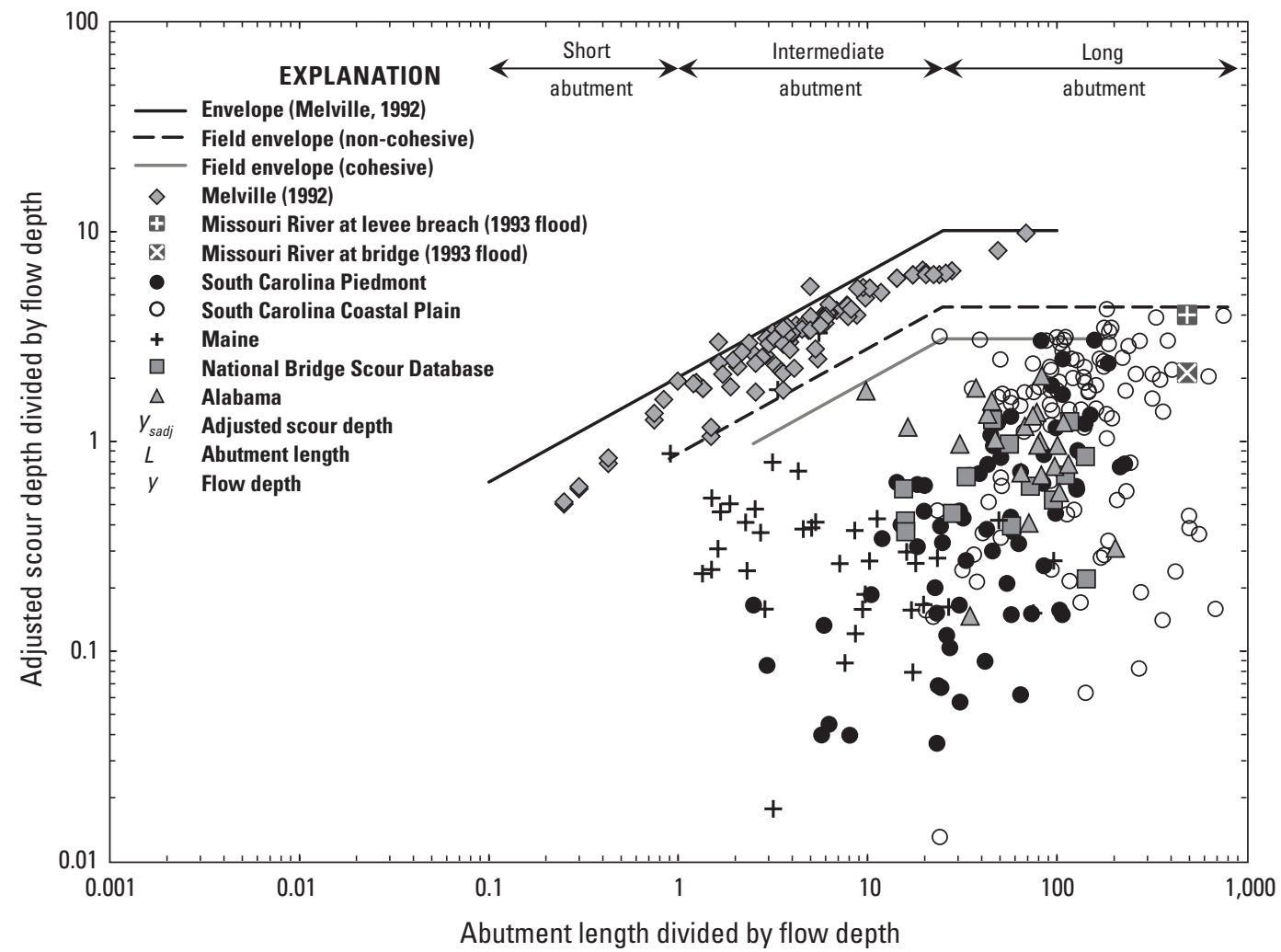

Figure 36. Relation of the relative abutment-scour depth $\left(y_{\text {sadj }} / y\right)$ to relative abutment length $(L / y)$ for selected laboratory and field data (from Benedict, 2016). 


\section{Comparison of the South Carolina Abutment- Scour Envelope Curves to Other Abutment-Scour Field Data}

To provide some support of the South Carolina abutmentscour envelope curves, Benedict (2015) plotted the field data from table 11 and the South Carolina data from table 7 against the envelope curves shown in figures 37 through 39. (Note: The larger of the two Missouri River data points [56 ft of scour] was excluded from these figures to provide a better plotting scale.) The Maine data (table 11) have characteristics that are distinctly different from those of the South Carolina data (table 7) and, therefore, do not provide an ideal comparison. However, the Maine data do provide some perspective on the range of abutment-scour depths for small, steep gradient streams. The Alabama data are associated with cohesive sediments, providing a good comparison for the Piedmont data. The NBSD data have site characteristics similar to the Coastal Plain data, providing a good comparison for those data.

The Piedmont and Coastal Plain geometric-contraction ratio abutment-scour envelope curves and the field data are shown in figure 37. Regarding the data patterns in figure 37, Benedict (2016) made the following observations. Three data points substantially exceed the envelope curves, including the two Missouri River data points (the largest point is not displayed) and one data point from Maine. The data point from Maine was collected with GPR, which tends to have a larger measurement uncertainty (Benedict, 2003), providing some explanation for the exceedance. With respect to the Missouri River data, Benedict (2016) noted that the levee breach associated with those measurements provide some explanation for their exceedance of the South Carolina envelope curves. Moreover, the large drainage area $\left(500,000 \mathrm{mi}^{2}\right)$, which greatly exceeds those of the South Carolina data, having a median value less than $100 \mathrm{mi}^{2}$, is indicative of longer flow durations and deeper deposits of alluvium flood plain sediments, both of which will promote larger scour depths than those of the South Carolina data. Figure 40 shows the relation of abutment-scour depth with respect to drainage area, using the same field data as figure 37 and including both measurements from the Missouri River. The upper bound of the abutment-scour data clearly increases with increasing drainage area and demonstrates how the drainage area for the Missouri River data is substantially beyond the range of the South Carolina data. The upper-bound pattern of the abutment-scour data shown in figure 40 highlights the importance of limiting application of the South Carolina abutment-scour envelope curves to sites having characteristics well within the range of the South Carolina data. It is notable that the Coastal Plain envelope curve in figure 37 encompasses all of the NBSD field data, which have site characteristics similar to the Coastal Plain data, providing support for the Coastal Plain geometric-contraction ratio envelope curve. Excluding the previously noted outliers, all of the field data fall within or very near the Piedmont envelope curve (fig. 37), providing support for that curve. If the Piedmont envelope curve is extended to the limits of the Coastal Plain envelope curve ( $m=0.98)$, the extended curve

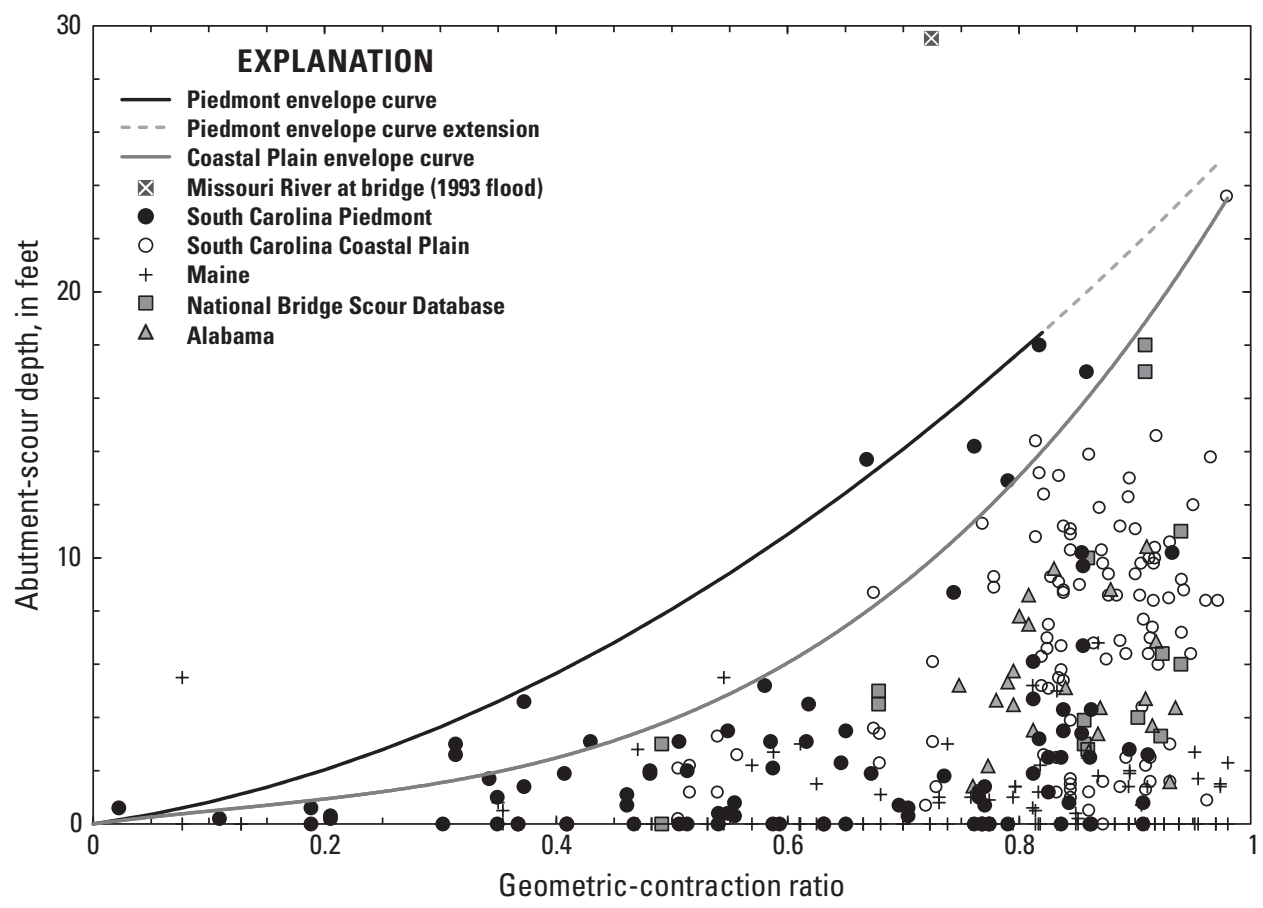

Figure 37. Comparison of the South Carolina abutment-scour envelope curves for geometric-contraction ratio to field data from other sources (from Benedict, 2016). 


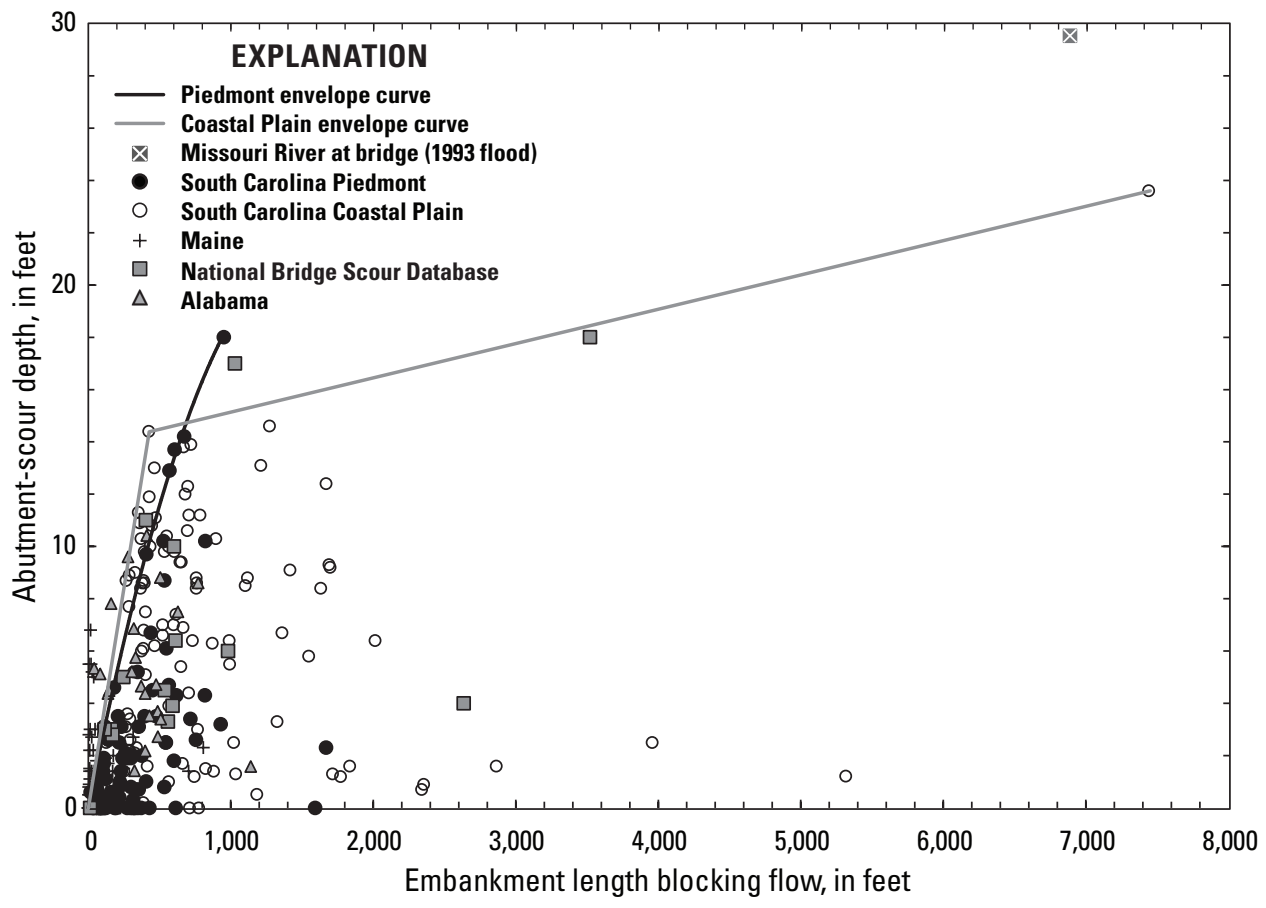

Figure 38. Comparison of the South Carolina abutment-scour envelope curves for embankment length to field data from other sources (from Benedict, 2016).

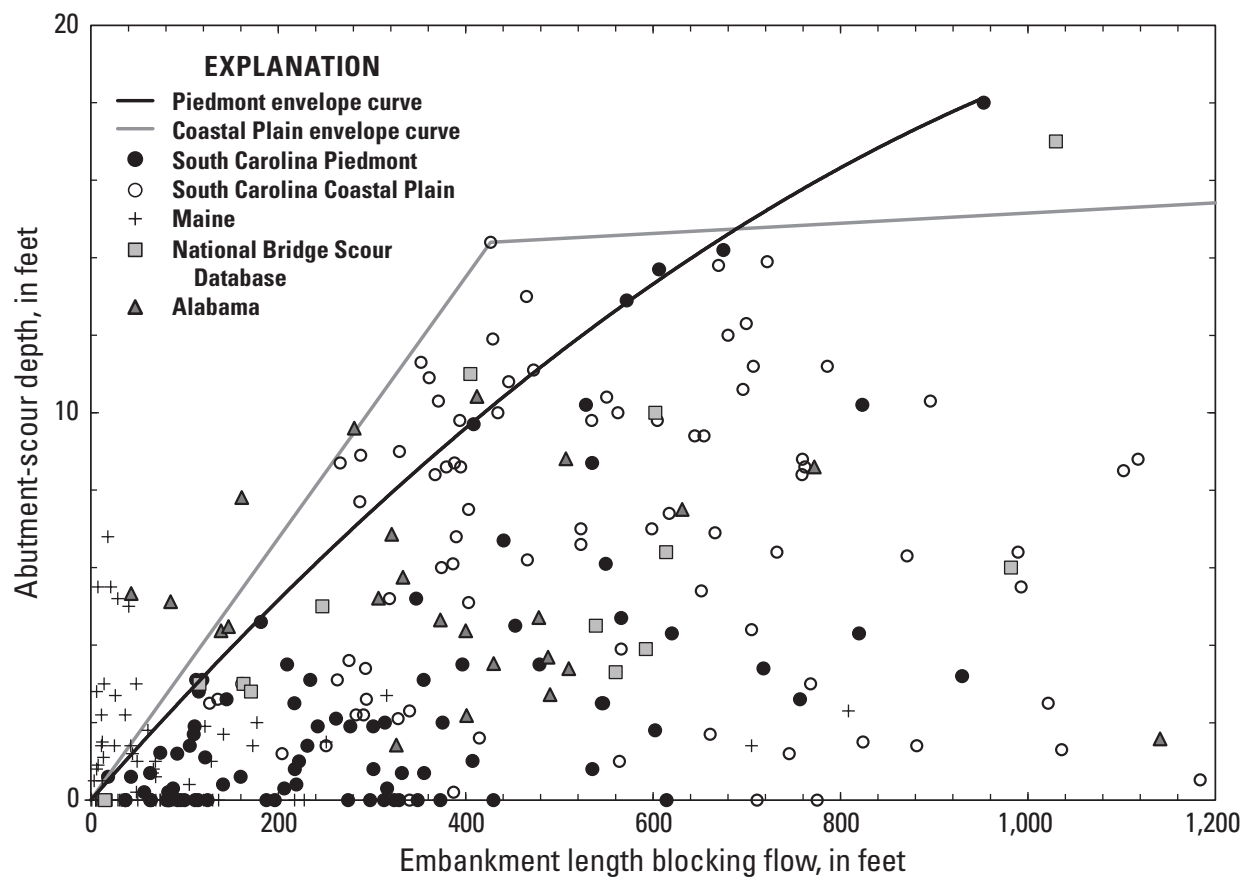

Figure 39. Comparison of the South Carolina abutment-scour envelope curves for embankment length to field data from other sources (truncated scale; from Benedict, 2016). 


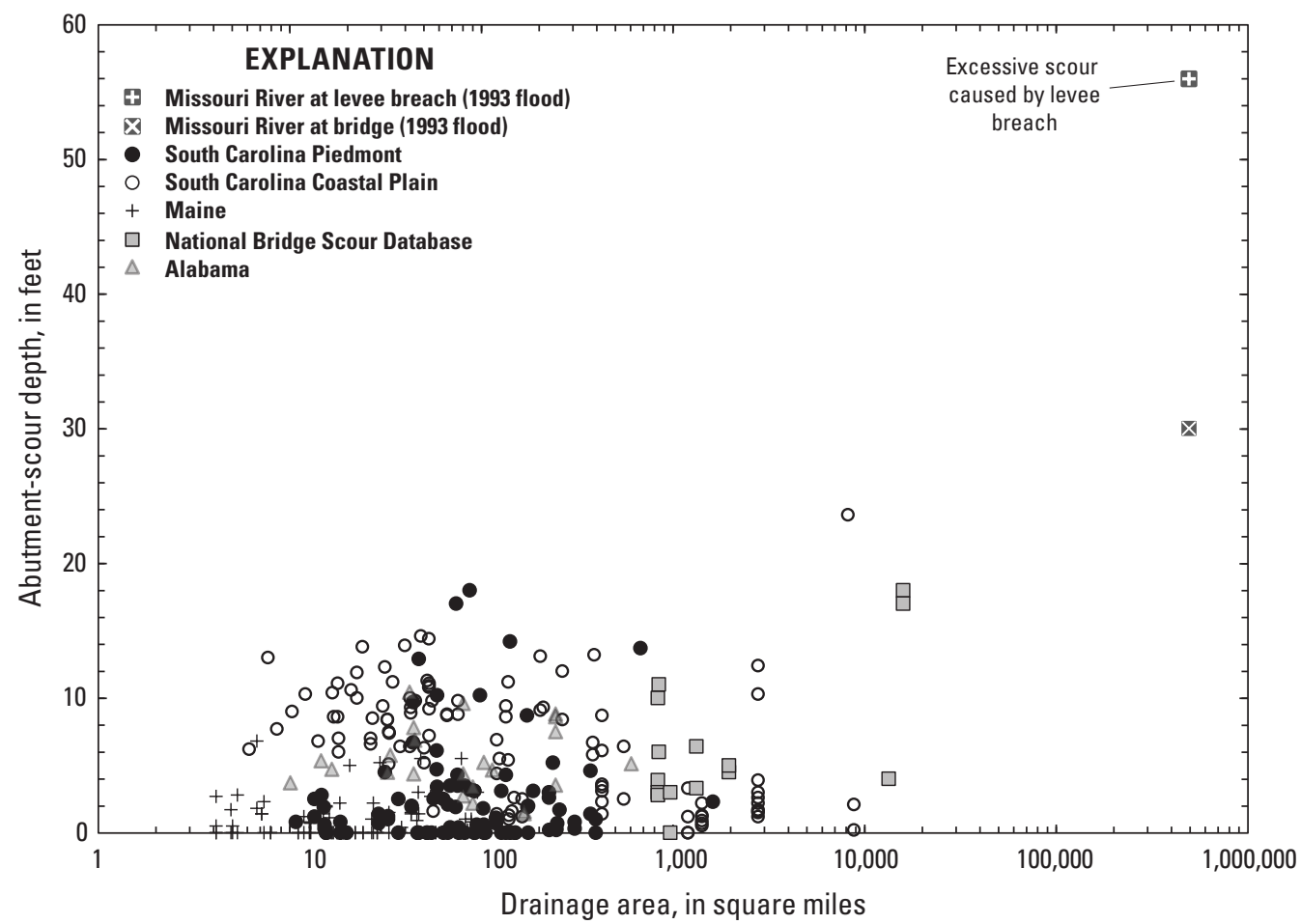

Figure 40. Relation of abutment-scour depth to drainage area for selected field data.

provides a conservative envelope curve for the field data, with the exception of the previously noted outliers. Although the South Carolina geometric-contraction ratio envelope curves can provide perspective on scour potential for the small, coarse-sediment streams of Maine, the curves generally will be conservative for such sites, especially at larger values of the geometric-contraction ratio.

The Piedmont and Coastal Plain embankment-length abutment-scour envelope curves and the field data are shown in figures 38 and 39, with figure 39 having a truncated scale to highlight the data patterns for smaller abutment lengths. Regarding the data patterns in figures 38 and 39, Benedict (2016) makes the following observations. Most of the data fall within the envelope curves, providing support for the curves. The exceedance of the Missouri River data is to be expected, and reasons for the exceedance were noted previously. The NBSD field data have similar site characteristics to the South Carolina data and fall close to or within the Piedmont and Coastal Plain envelope curves, providing support for the curves. The Alabama data that exceed the South Carolina envelope curves are associated with multiple-bridge openings. Benedict (2003) noted that field data from multiple-bridge openings did not always conform to the abutment-length envelope curves, in part, because of the difficulty in determining the embankment length blocking flow at such sites, providing some explanation for their exceedance. There are 18 Maine data points that exceed the envelope curves. Thirteen data points are small scour depths ( $3 \mathrm{ft}$ or less), falling in close proximity to the curves and are not of major concern. The remaining five data points are associated with GPR measurements and fall approximately 5 to $6 \mathrm{ft}$ away from the curves. As noted previously, GPR tends to have a larger measurement uncertainty, providing some explanation for the exceedance of these data.

Although the field data (table 11) used to compare with the South Carolina abutment-scour envelope curves are limited, the data indicate that the envelope curves are reasonable for sites having similar characteristics to those of the South Carolina data. The exceedance of data for the Missouri River at I-70 indicates that the South Carolina abutmentscour envelope curves are not appropriate for sites with large drainage areas and highlights the importance of limiting their application to sites having similar characteristics to the data listed in table 7. 


\section{Relative Increase in Theoretical Abutment Scour Associated With the 100- to 500-Year Flows}

As previously described in the report section "South Carolina Clear-Water Abutment-Scour Field Data," a substantial portion of the field data used to develop the South Carolina abutment-scour envelope curves included scour measurements likely associated with historic flows near the 100 -year flow magnitude. Therefore, the envelope curves can be used to assess scour potential for such flow conditions (Benedict, 2003). (Note: The abutment-scour envelope curves should not be considered a definitive estimate of the abutment-scour depth associated with the 100-year flow.) However, the South Carolina abutment-scour envelope curves were not recommended for assessing scour potential for extreme floods such as the 500-year flow (Benedict, 2003). In order to gain insights on the relative increase in abutment-scour depth associated with the 100- to 500-year flows, a theoretical adjustment coefficient similar to those developed for pier scour (see the report section "Relative Increase in Theoretical Pier Scour Associated With the 100- to 500-Year Flows") can be developed for abutment scour. Although such adjustments do not provide a definitive estimate of the 500-year abutment-scour depth, they do provide perspective on the relative increase. A summary of the compiled theoretical abutment-scour data and the analysis of the 500-year flow adjustment coefficient is presented below.

\section{Theoretical Abutment-Scour Data}

The South Carolina Theoretical Bridge Scour Database (http://dx.doi.org/10.3133/sir20165121), as previously described in the report section "Theoretical Pier-Scour Data," includes 134 theoretical abutment-scour depths for both the 100- and 500-year flows that were used to evaluate the 500 -year flow adjustment coefficient. In addition to the South Carolina data, the Missouri level-2 data (Huizinga and Rydlund, 2004) included theoretical scour computations at 223 abutment-scour depths that were used as a means to confirm the trends of the South Carolina data. The Missouri data are available at http://pubs.usgs.gov/sir/2004/5213/.

\section{The 500-Year Flow Adjustment Coefficient}

The relation of the theoretical abutment scour for the 100- and 500-year flows for the South Carolina and Missouri data is shown in figure 41, including trend lines through each dataset. Summary statistics for the data are provided in table 12. The scatter about the trend line for the South Carolina data is small, and the coefficient of determination is high (0.96) indicating that there is a strong correlation in the data. The trend line through the Missouri data falls in close proximity to the South Carolina trend line indicating that the South Carolina trend line is reasonable. The equation for the South Carolina trend line is as follows:

$$
\text { Scour }_{500}=1.21 \text { Scour }_{100}
$$

where

$$
\begin{aligned}
& \text { Scour }_{500} \begin{array}{c}
\text { is the 500-year flow theoretical scour } \\
\text { depth, in feet; and }
\end{array} \\
& \text { Scour }_{100} \quad \begin{array}{c}
\text { is the } 100 \text {-year flow theoretical scour } \\
\text { depth, in feet. }
\end{array}
\end{aligned}
$$

Equation 18 can be divided by Scour $_{100}$ and simplified to the following form:

$$
\text { Scour }_{500}=1.21
$$

\begin{tabular}{|c|c|c|c|c|}
\hline \multirow[b]{2}{*}{$\begin{array}{l}\text { Descriptive } \\
\text { statistic }\end{array}$} & \multicolumn{2}{|c|}{ South Carolina ( $\mathrm{N}=134$ ) } & \multicolumn{2}{|c|}{ Missouri ( $\mathrm{N}=223$ ) } \\
\hline & $\begin{array}{l}\text { Ratio of } 0500 \text { and } 0100 \\
\text { theoretical abutment- } \\
\text { scour depths }\end{array}$ & $\begin{array}{c}\text { Drainage } \\
\text { area } \\
\left(\mathrm{mi}^{2}\right)\end{array}$ & $\begin{array}{l}\text { Ratio of } 0500 \text { and } 0100 \\
\text { theoretical abutment- } \\
\text { scour depths }\end{array}$ & $\begin{array}{c}\text { Drainage } \\
\text { area } \\
\left(\mathrm{mi}^{2}\right)\end{array}$ \\
\hline Minimum & 0.83 & 5.12 & 1.01 & 1.30 \\
\hline 25 th percentile & 1.16 & 15.3 & 1.22 & 12.6 \\
\hline Mean & 1.24 & 643 & 1.65 & 269 \\
\hline Median & 1.21 & 46.5 & 1.32 & 28.1 \\
\hline 75th percentile & 1.29 & 108.0 & 1.70 & 141 \\
\hline Maximum & 1.93 & 12,990 & 9.60 & 14,000 \\
\hline
\end{tabular}

where $K_{500}$ is the theoretical 500-year flow adjustment coefficient that represents the ratio of the 500-year flow

Table 12. Descriptive statistics for the ratio of the 500- and 100-year flow, theoretical abutment-scour depths used in the regression analysis for selected theoretical data from South Carolina and Missouri.

[N, number of measurements; Q500, 500-year flow; Q100, 100-year flow; $\mathrm{mi}^{2}$, square mile] 


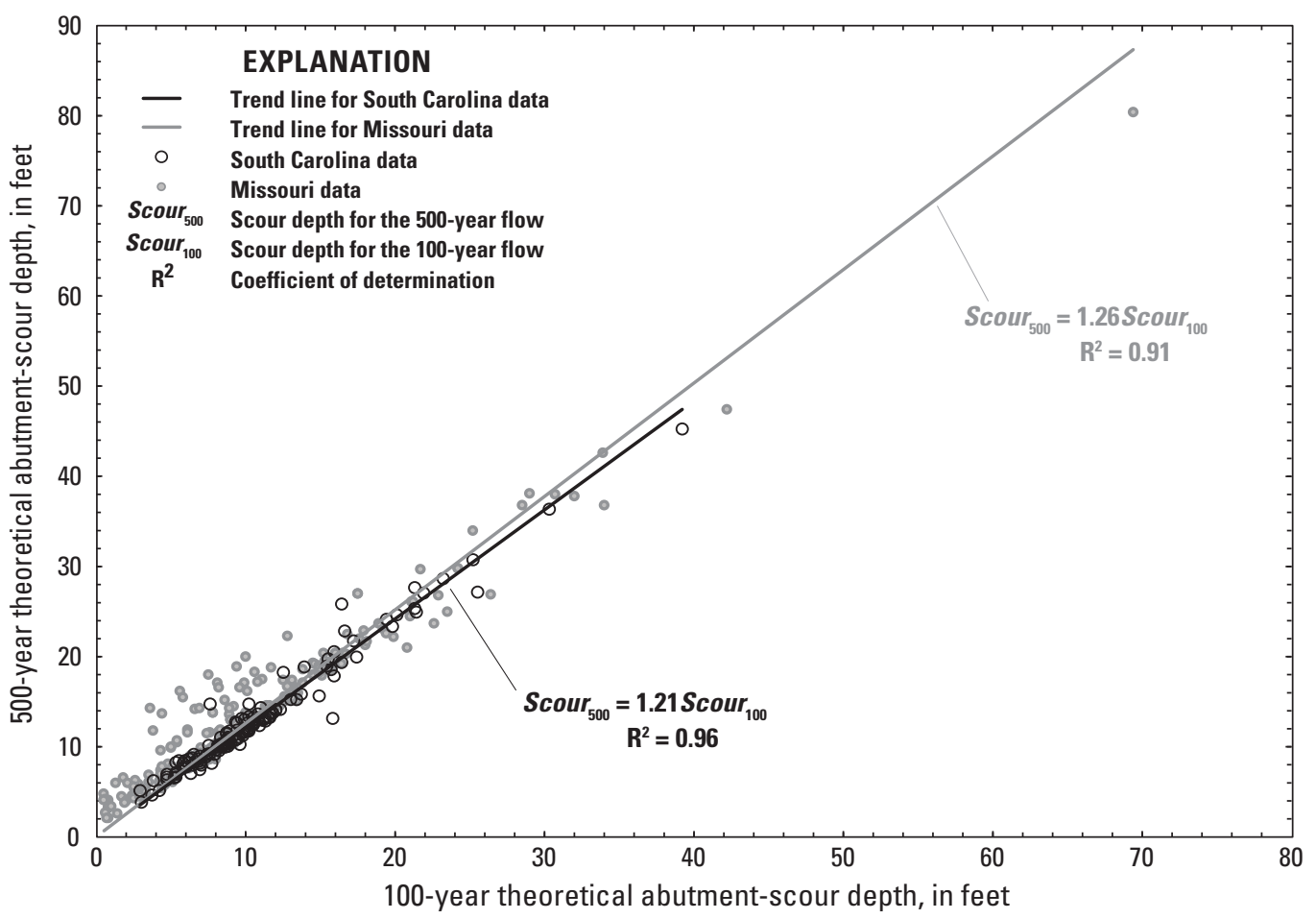

Figure 41. Relation of the 100- and 500-year flow, theoretical abutment-scour depths for selected data from level-2 bridge-scour studies in South Carolina and Missouri.

to 100-year flow theoretical abutment-scour depths. Other variables are as previously defined. The $K_{500}$ coefficient can be applied to the South Carolina abutment-scour envelope curves to increase the abutment-scour depth by the relative increase in theoretical abutment scour associated with the 100- to 500-year flow condition. The $K_{500}$ is a helpful tool for gaining perspective on the relative increase of theoretical scour associated with the 100- to 500-year abutment-scour depth. However, the adjusted envelope curve values should not be considered a definitive estimate of the abutment scour associated with the 500-year flow.

\section{Application and Limitations of the South Carolina Clear-Water Abutment-Scour Envelope Curves}

The South Carolina clear-water abutment-scour envelope curves (figs. 26, 27, 30, 31, 33, 34) can be useful supplementary tools for assessing clear-water abutment-scour depth at bridges in South Carolina. When using these envelope curves to assess abutment-scour potential, one must select a reference surface, estimate the embankment-length and the geometric-contraction ratio, select the appropriate abutmentscour envelope curve, and evaluate other scour components in the abutment region. It also is important that the user be mindful of the limitations and potential uncertainty of these curves. The clear-water abutment scour envelope curves were developed using modeled hydraulic data to provide an estimate of the "true" hydraulic conditions that may have created the observed scour. It is important that site characteristics at the bridge site to which the envelop curves are being applied have similar characteristics to the sites used to develop the envelope curves. The envelop curves were developed using field data from sites with flows approaching the 100-year flow but should not be interpreted as representing the "100-year" scour estimate and also should not be used to evaluate clearwater abutment scour depths for extreme conditions, such as those approaching the 500-year flow. To gain insights on the relative change in the theoretical clear-water abutment scour depth associated with the 100- to 500-year flow, the 500-year scour coefficient (eq. 19) may be applied to the envelope curve estimate. Data used to develop the clear-water abutment scour envelope curves did not include failure from embankment washout and, therefore, the envelope curves should not be used to assess this type of abutment scour. The envelope curves are not intended for tidally influenced sites that may be encountered in the Coastal Plain. 


\section{Selecting a Reference Surface}

Benedict (2003) used the average, undisturbed flood plain elevation in the abutment-scour region as the reference surface to determine the abutment-scour depth for the South Carolina data, and this reference surface should be used when assessing abutment scour with the South Carolina abutment-scour envelope curves. The reference surface can be determined by reviewing flood plain elevations from SCDOT road and bridge plans, surveyed cross sections, and (or) site visit observations. In many cases, the flood plain in the region of the abutment is relatively flat, so estimating an average flood plain elevation in the region of anticipated scour is not a difficult task. However, there can be cases where the flood plain slopes substantially in the lateral and (or) longitudinal direction making the determination of a reference surface more difficult. In such cases, judgment must be applied, bearing in mind that lower reference-surface elevations will produce lower scour-hole elevations.

\section{Estimating the Embankment Length and the Geometric-Contraction Ratio}

The explanatory variables used in the original and modified abutment-scour envelope curves are the embankment length and the geometric-contraction ratio. The envelope curves can be sensitive to the selection of these variables; therefore, it is important that accurate estimates of these variables be obtained. When developing the envelope curves, the embankment length and the geometric-contraction ratio were determined by using the WSPRO flow model (Shearman, 1990; Arneson and Shearman, 1998) for the 100-year flow condition (figs. 28, 29). When applying the envelope curves at specific sites, these variables also should be estimated for the 100-year flow at the site of interest. The WSPRO model generally uses the full flood plain width (left edge of water to right edge of water) for the natural, unconstricted approach cross section, with no adjustment for ineffective flow areas, thus providing the largest justifiable estimate for embankment lengths and geometric-contraction ratio. It is important that a similar approach be used when determining these variables to assure that the largest justifiable estimate is obtained on the basis of the full flood plain width for the natural, unconstricted approach cross section. It also is recommended that topographic maps and road plans, when available, be used to verify the embankment lengths and the geometric-contraction ratio. When discrepancies exist between these sources, judgment should be used to determine a reasonable, yet conservative, estimate of the explanatory variables. (Note: The bridge hydraulics algorithm and associated cross sections in the HEC-RAS model [Brunner, 2016] differ from that of the WSPRO model, and when using the HEC-RAS model to estimate the embankment lengths and the geometric-contraction ratio, judgment must be used to assure that the estimates are comparable to those used in
Benedict [2003], which were based on the WSPRO model. Guidance regarding this matter is presented in the report section "Guidance for Applying the South Carolina BridgeScour Envelope Curves.")

\section{Selecting the Appropriate Clear-Water Abutment-Scour Envelope Curve}

Clear-water abutment-scour depth can be assessed using the original clear-water abutment-scour envelope curves (Benedict 2003; figs. 26, 27, 30, 31; table 7) or the modified clear-water abutment-scour envelope curves (Benedict and Caldwell, 2012; figs. 33, 34; tables 8, 9). The original envelope curves have broader application than the modified envelope curves, with the modified envelope curves providing some refinement for assessing the potential for abutment scour at smaller embankment lengths. Criteria for selecting the appropriate envelope curve will be based on the regional location and site characteristics for the bridge of interest. Selection guidance with respect to the modified and original envelope curves follows.

\section{Original Clear-Water Abutment-Scour Envelope Curves}

In general, the original clear-water abutment-scour envelope curves (Benedict, 2003) have broader application than the modified clear-water envelope curves (Benedict and Caldwell, 2012). When assessing abutment-scour depths using the original envelope curves, one must select envelope curves for the appropriate physiographic region (Piedmont or Coastal Plain) and use both the embankment-length (figs. 26, 27) and the geometric-contraction ratio (figs. 30, 31) envelope curves for the selected region to assess potential abutment-scour depth. These two envelope curves often provide different estimates for the upper bound of abutment-scour depth, so one must use judgment to select the most appropriate depth. Application of these envelope curves to selected sites in South Carolina has shown that the geometric-contraction-ratio envelope for both physiographic regions will often provide higher estimates of the upper bound of abutment-scour depth than the embankment-length envelope curves. The larger estimates can be attributed, in part, to the fact that the geometric-contraction-ratio envelope curves cannot account for variation in embankment length at a given abutment. For example, a 100-ft-long bridge crossing a 500-ft-wide Piedmont flood plain has a geometric-contraction ratio of 0.8. Similarly, a 200-ft-long bridge crossing a 1,000-ft-wide flood plain will have the same geometric-contraction ratio. If these bridges are symmetrically located on the flood plain, the embankment lengths will be 200 and $400 \mathrm{ft}$, respectively. Using the geometric-contraction-ratio envelope curve (fig. 30) to estimate abutment-scour depth, the scour depth will be 
identical for both bridges. It is reasonable, however, to assume (with all other variables the same) that the bridge with the shorter embankments will have smaller scour depths than the bridge with longer embankments.

Another example of where excessive estimates of abutment-scour depth may occur is at sites having eccentric bridge crossings where one embankment is substantially shorter in length. In such cases, the geometric-contractionratio envelope will give identical scour depths at both abutments; however, with other variables remaining constant, it is reasonable to assume that scour depths will be less at the shorter embankment of an eccentric bridge crossing. To avoid overestimates of the upper bound of abutment-scour depth, it may be reasonable to use the embankment-length envelope curve as the primary tool for estimating abutmentscour potential in the Piedmont and Coastal Plain of South Carolina. If a conservative estimate of the upper bound of abutment-scour potential is needed, the largest estimate of the upper bound of abutment scour obtained from the geometriccontraction-ratio and embankment-length envelope curves may be more appropriate.

\section{Modified Clear-Water Abutment-Scour Envelope Curves}

The modified abutment-scour envelope curves (Benedict and Caldwell, 2012) can be used to provide refined estimates of the upper bound of abutment scour potential for smaller embankment lengths. The modified envelope curves are limited to embankment lengths less than or equal to $500 \mathrm{ft}$, and the geometric-contraction ratios should not exceed 0.85 or 0.9 for the Piedmont or Coastal Plain, respectively. The limits of the explanatory variables for the modified abutment-scour envelope curves are presented in table 9. If the geometriccontraction ratio for the bridge of interest is less than the minimum value specified in table 9 , the minimum value should be used in the equation. Additionally, the site characteristics of the bridge of interest should fall within the range of the South Carolina regional data (Piedmont or Coastal Plain) used to develop the modified envelope curves as listed in table 8. If the above criteria are not met, then the original clear-water abutment-scour envelope curves (Benedict, 2003) must be used.

For embankment lengths that fall between the embankment-length categories of the modified envelope curves (figs. 33, 34; table 9), it is possible to interpolate between the modified envelope curves in order to refine the estimate of the upper bound of abutment-scour potential; however, it may be prudent to apply the modified envelope curves only by embankment-length category. Using this category application, there may be cases when the modified envelope curves provide larger values of abutment-scour potential compared to the original abutment-scour envelope curves. In such cases, it is recommended that the value from the original abutmentscour envelope curve be used in the assessment.

\section{Single-Bridge Openings}

For the bridge sites associated with the Piedmont and Coastal Plain data used to develop the original abutment-scour envelope curves (Benedict, 2003), 94 and 62 percent of the bridges, respectively, were associated with single-bridge openings. All of the single-bridge opening data for the Piedmont and Coastal Plain regions plotted within their respective embankment length and geometric-contraction ratio envelope curves. Therefore, if a single-bridge opening in the Piedmont or Coastal Plain has site conditions similar to bridges included in this study (table 7), it is appropriate to use the embankment length or the geometric-contraction ratio envelope curves to estimate the upper bound of abutment-scour potential. As previously discussed, it may be reasonable to use the embankment-length envelope curve as the primary tool for estimating abutment-scour depth at single-bridge openings in the Piedmont and Coastal Plain of South Carolina. If, however, a conservative estimate of the upper bound of abutment-scour potential is needed, the larger scour depth obtained from the geometric-contraction ratio or embankment-length envelope curves may be more appropriate.

Benedict (2003) noted that bridges crossing swamps with poorly defined low-flow channels, with bridge lengths approximately $240 \mathrm{ft}$ or less, tend to develop a single large scour hole that encompasses the entire bridge opening (fig. 24; see the report section "Field Conditions That Influence Clear-Water Abutment-Scour Potential"). To associate these single scour holes with abutment variables, Benedict (2003) recommended using the longer of the left or right embankment lengths in the assessment. Therefore, when assessing abutment-scour potential at single-bridge openings crossing swamps, with bridge lengths approximately $240 \mathrm{ft}$ or less, the longest of the left or right embankment lengths should be used in conjunction with the appropriate embankment-length envelope curves that utilize this variable (figs. 26, 27, 33, 34). The geometric-contraction-ratio envelope curves (figs. 30, 31) also may be used to assess abutment-scour potential at such bridges, using judgment to select the final value. The estimated upper bound of the scour depth will be assumed to represent the depth of the large, single scour hole that will likely extend from abutment toe to abutment toe.

\section{Multiple-Bridge Crossings}

Special consideration must be given to the selection of the appropriate envelope curve when dealing with multiplebridge openings, and a discussion of assessing abutment-scour depth at such bridges follows. Flood plain widths in the Piedmont are relatively narrow, and therefore, multiple-bridge openings are not common. In contrast, flood plains in the Coastal Plain are typically flat and wide and often have multiple-bridge openings. The South Carolina abutment-scour data included 2 bridges associated with a multiple-bridge crossing in the Piedmont in contrast to 31 in the Coastal Plain. Five abutment-scour measurements associated with 
multiple-bridge crossings plotted above the original embankment-length envelope curves (figs. 26, 27). This anomaly is possibly caused by the irregular distribution of flow that commonly occurs at a multiple-bridge site. In addition, stagnation points for flow between multiple bridges, as estimated by the simplified routine in the WSPRO (Shearman, 1990; Arneson and Shearman, 1998) model, may be in error. Any error in this estimate will provide improper estimates of the embankment lengths. In contrast, all data (single and multiple bridges) plotted near or within the geometric-contraction-ratio envelope curves. Therefore, to assure that abutment-scour potential is not underestimated at a multiple-bridge crossing, Benedict and Caldwell (2012) recommended that the modified abutment-scour envelope curves (figs. 33, 34) not be used to assess multiple-bridge openings. Additionally, Benedict (2003) recommended that only the original geometric-contractionratio envelope curves (figs. 30,31) be used to assess abutmentscour potential at multiple-bridge crossings rather than the original embankment-length envelope curves (figs. 26, 27). The exception to this recommendation is for multiple-bridge openings in the Coastal Plain where the embankment length is greater than or equal to $426 \mathrm{ft}$. This value represents the breakpoint for the Coastal Plain embankment-length envelope curve (fig. 27) where the upper bound of abutment-scour potential becomes less sensitive to the selection of the embankment length. Additionally, the multiple-bridge opening data that exceeded the Coastal Plain embankment-length envelope curve were all associated with embankment lengths less than $426 \mathrm{ft}$. Therefore, when a multiple-bridge site in the Coastal Plain has an embankment length that equals or exceeds $426 \mathrm{ft}$, Benedict (2003) noted that the original embankment length and geometric-contraction ratio envelope curves for the Coastal Plain could be used to assess the upper bound of abutment-scour potential following the guidance for a singlebridge opening. For a multiple-bridge site in the Coastal Plain with an embankment length less than $426 \mathrm{ft}$, assessment of the upper bound of abutment-scour potential should be limited to the original geometric-contraction ratio envelope curve.

The determination of the embankment length and geometric-contraction ratio for a multiple-bridge opening differs from that of a single-bridge opening. In the case of a single-bridge opening, the unconstricted approach cross section is used to evaluate both variables. In the case of a multiple-bridge opening, the WSPRO model estimates the portion of the unconstricted approach cross section that contributes flow to each bridge and subdivides the approach cross section accordingly into slices. The geometriccontraction ratio is determined for each bridge by using the associated slice section rather than the entire approach cross section. Each bridge opening can be projected onto the corresponding slice section to determine the left and right embankment lengths. The multiple-bridge opening hydraulics algorithm in the HEC-RAS model (Brunner, 2016) is similar but not identical to the algorithm in the WSPRO model. Therefore, when using the HEC-RAS model to evaluate $L$ and $m$ at a multiple-bridge opening, caution and engineering judgment must be used to assure that conservative yet reasonable estimates of $L$ and $m$ are obtained. Reference should be made to Arneson and Shearman (1998) and Brunner (2016) for additional details regarding the hydraulics of multiple-bridge openings for the WSPRO and HEC-RAS models, respectively.

\section{Contraction and Pier Scour Within the Clear-Water Abutment-Scour Region}

Benedict (2003) concluded that contraction scour should not be considered a contributing component to total scour in the abutment-scour region. It is notable that Sturm (2004) and Ettema and others (2010) made similar conclusions on the basis of laboratory investigations, giving support for this recommendation. Therefore, when using the original (Benedict, 2003) or modified (Benedict and Caldwell, 2012) clear-water abutment-scour envelope curves to assess total scour depth at abutments, no adjustment for contraction scour in the abutment region is required.

With regard to pier scour, Benedict (2003) concluded that the South Carolina abutment-scour data included any influence of pier scour for the piers located in the abutment-scour region at the time of the measurement. A review of the field data indicated that piers located in the abutment-scour region were limited to multiple-column bents, having pier widths $2.3 \mathrm{ft}$ or less with minimal skew. Therefore, when using the original (Benedict, 2003) or modified (Benedict and Caldwell, 2012) clear-water abutment-scour envelope curves to assess total scour depth at abutments, no adjustment is required for pier scour associated with the pier characteristics of the South Carolina data as previously described. The South Carolina abutment-scour data did not include sufficient information to draw conclusions regarding the influence of piers having pier widths greater than $2.3 \mathrm{ft}$. Therefore, when pier widths exceed $2.3 \mathrm{ft}$, judgment should be used to determine if the results of the clear-water abutment-scour envelope curves should be adjusted to account for the effects of the wider piers. Judgment also should be used to account for the effects of debris and (or) pier skew if they are thought to substantially influence pier scour, regardless of the pier width.

The above guidance for piers is slightly modified for the Piedmont. When the upper bound of abutment-scour potential in the Piedmont is estimated to be $5 \mathrm{ft}$ or less with the original or modified envelope curves, judgment should be used to account for the effect of pier scour within the abutment region regardless of the pier width. Ettema and others (2010) conducted a limited laboratory investigation regarding the influence of a pier on abutment-scour depth and concluded that pier presence in the abutment-scour region did not substantially increase abutment-scour depth. The limited nature of the investigation makes it difficult to draw broad applications from the investigation, but reference can be made to that report to gain insights on the influence of a pier in the abutment-scour region. For additional information on the recommendations for contraction and pier scour in the abutment-scour regions, reference can be made to Benedict (2003). 


\section{Top Width of Abutment-Scour Hole}

Benedict (2003) observed that the toe of the abutment frequently coincided with the edge of the abutment-scour hole. Therefore, using the abutment toe as a reference location for the bank of the abutment-scour hole, the lateral extent of the area affected by scour can be assessed by estimating the scour-hole top width. Figure 42 shows the relation of observed scour-hole top widths and observed scour depths for two abutment-scour hole patterns: (1) individual abutment-scour holes at the left and (or) right abutments that do not overlap (figs. 21 and 25) and, (2) single abutment-scour holes that encompassed the entire bridge opening, abutment toe to abutment toe (fig. 24). Figure $42 A$ represents the envelope for pattern 1 and includes bridges in the Piedmont and Coastal Plain. As noted previously (see report section, "Field Conditions That Influence ClearWater Abutment-Scour Potential") bridges over poorly defined swampy channels or flood plain relief bridges (fig. 5) approximately $240 \mathrm{ft}$ or less in length tended to form a large, single scour hole that encompassed the entire bridge opening from abutment toe to abutment toe (fig. 24). These types of bridges with scour-hole pattern 2 are represented in figure $42 B$. (Note: Bridges approximately $240 \mathrm{ft}$ or less and having well defined channels will tend to have abutment-scour holes patterns like pattern 1 as represented in figure $42 A$.)

The scatter in the depth-to-width ratio of the observed scour is large, making estimates of scour-hole top width difficult. Using the envelope curves in figure 42 , a conservative estimate of top width can be obtained. These estimates could be unreasonable under some site conditions. At Piedmont sites where the overbank width (at setback abutments) is less than the estimated abutment scour-hole top width, it may be reasonable to limit the estimated scour-hole top width to the width of the overbank. For bridges having site characteristics comparable to abutment-scour hole pattern 2 (poorly defined swampy channels or flood plain relief bridges (fig. 5) and approximately $240 \mathrm{ft}$ or less in length), it may be reasonable to assume that the scour-hole top width equals the toe-to-toe width.

\section{Limitations of the South Carolina Clear-Water Abutment-Scour Envelope Curves}

The South Carolina clear-water abutment-scour envelope curves (figs. 26, 27, 30, 31, 33, 34) can be useful supplementary tools for assessing clear-water abutment-scour potential at bridges in South Carolina. However, the following limitations of these empirical envelope curves can restrict their use. Therefore, the envelope curves should not be relied upon as the only tool for assessing abutment scour but rather should be used in conjunction with the prevailing scour-prediction technology (currently HEC-18). To best assess potential scour, one should compile and study the available information for a given site, evaluate scour with the South Carolina envelope curves and the prevailing scour technology (currently HEC-18), and then bring sound engineering principles to bear on the final estimate of potential abutment-scour depth.
- The abutment-scour envelope curves were developed from a limited sample of bridges in the Piedmont and Coastal Plain, and it is possible that scour depths could exceed the envelope curves. Additionally, the explanatory variables, embankment length and geometric-contraction ratio, used to develop the abutment-scour envelope curves, were based on modeled hydraulic data that will have some degree of error. On the basis of these limitations, it may be prudent to apply a safety factor to the abutment-scour envelope curves.

- Application of the abutment-scour envelope curves should be limited to bridges having site characteristics similar to those used to develop the envelope curves (tables 7, 8). Also, the abutment-scour database (Benedict, 2003) can be used to review studied sites to gain insights about potential scour at unstudied sites. Limits for embankment length and the geometriccontraction ratio have been defined for each envelope, and care should be given to remain within those limits. When site characteristics are substantially different from the site characteristics of the sites used in the current study, other methods for assessing abutmentscour potential should be considered.

- The abutment-scour envelope curves were developed by using field data that represent scour resulting from flows near the 100-year flow but should not be interpreted as representing the " 100 -year" scour estimate and should not be used to evaluate clear-water abutment-scour depths for larger flows, such as the 500 -year flow. To gain insights on the relative change in the theoretical abutment-scour depth associated with the 100-year to 500-year flow, the 500-year scour coefficient (eq. 19) may be applied to the envelope curves but should not be interpreted as representing the "500-year" scour estimate.

- An additional scour problem that frequently occurs in South Carolina is the washout of road embankments. Typically, washout occurs at smaller bridges that create a large contraction of flow. The magnitude of this problem is seen in bridge failure statistics from the October 1990 flood. This event caused 80 bridges to fail in South Carolina with 79 of these failures attributed to embankment washout (Hurley, 1996). Data collected in the current study did not include failure from embankment washout; therefore, envelope curves in this report should not be used to assess this type of abutment scour.

- The abutment-scour envelope curves do not account for adverse field conditions that may affect abutment scour at bridges, such as channel bends, debris, or field conditions that may create unusual flow distributions that direct flow into the abutment-scour region during high flows. 


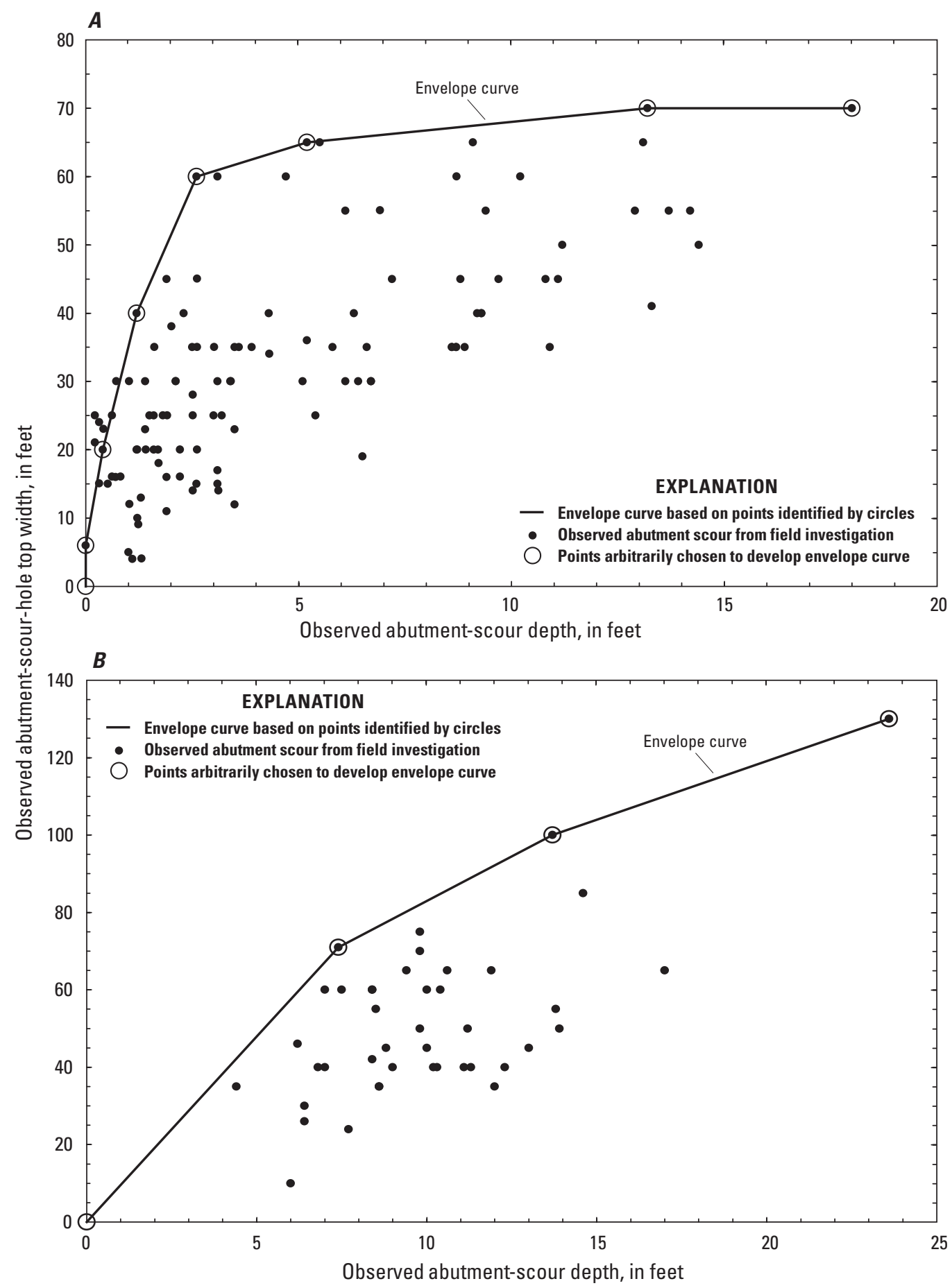

Figure 42. Relation of abutment scour-hole top width and abutment-scour depth at bridges $(A)$ greater than 240 feet in length and $(B)$ swampy and flood plain relief bridges, 240 feet or less in length, in the Piedmont and Coastal Plain of South Carolina (from Benedict, 2003). 


\section{The South Carolina Clear-Water Contraction-Scour Envelope Curve}

Bridge contraction scour occurs when a bridge substantially constricts the natural flow of a stream and causes the streambed to erode in the general region of the bridge. The mechanisms that create the contraction scour are associated with increased flow velocities and vortexes generated by the contraction of flow. Contraction scour is generally classified as clear-water or live-bed, which refers to the sediment-transport conditions at the time of scour (Arneson and others, 2012). Clear-water contraction scour occurs when approach-flow velocities are insufficient to transport sediments along the bed and into the scoured region. Equilibrium conditions for clear-water contraction scour are attained when flow velocities in the contraction have been reduced by bed degradation to the critical velocity of the bed sediments. In South Carolina, clear-water contraction scour typically occurs on the flood plain (also called overbank) of a bridge (figs. 4, 5). Live-bed contraction scour is discussed later in the report.

\section{South Carolina Clear-Water Contraction-Scour Field Data}

Benedict (2003) made 75 measurements of clearwater contraction scour at selected sites in the Piedmont of South Carolina (table 13), with scour depths ranging from 0.0 to $4.5 \mathrm{ft}$. The flood plain soils of the Piedmont are generally clayey with varying degrees of cohesion, and the median grain size ranged from less than 0.062 to 0.99 millimeter $(\mathrm{mm})$. The bridge sites where data were collected also were part of the abutment-scour investigation by Benedict (2003), and reference can be made to the report section "South Carolina Clear-Water Abutment Scour Field Data" for additional information about these sites. Expanding on the work by Benedict (2003), Benedict and Caldwell (2006) made 64 measurements of clear-water contraction scour at selected sites in the Coastal Plain of South Carolina (table 13), with scour depths ranging from 0.0 to $3.9 \mathrm{ft}$. The soils of the Coastal Plain are generally sandy (with some clayey soils), and the median grain size ranged from less than 0.062 to $0.56 \mathrm{~mm}$. These bridges also were part of the clear-water pier-scour investigation by Benedict and Caldwell (2006), and reference can be made to the report section "Clear-Water Pier-Scour Envelope Curve" for additional information about these sites. Bridge sites where the South Carolina clear-water contraction-scour data were collected can be identified in appendix 1 and figure 1 .

All measurements were associated with contraction scour occurring in the clear-water scour regions on the bridge overbanks (fig. 4) or at flood plain relief bridges and bridges over swampy channels (fig. 5). The scour measurements were made in the contraction-scour region, as defined in figure 23, beyond the deeper scour depths typically associated with the abutment-scour region. The reference surface used to determine the contraction-scour depth was the average undisturbed

Table 13. Range of selected characteristics of clear-water contraction scour field data collected in the flood plains of selected sites in South Carolina (Benedict and Caldwell, 2006).

$\left[\mathrm{mi}^{2}\right.$, square mile; $\mathrm{ft} / \mathrm{ft}$, foot per foot; $\mathrm{ft} / \mathrm{s}$, foot per second; $\mathrm{ft}$, foot; $\mathrm{mm}$, millimeter; $<$, less than]

\begin{tabular}{|c|c|c|c|c|c|c|c|}
\hline $\begin{array}{l}\text { Range } \\
\text { value }\end{array}$ & $\begin{array}{c}\text { Drainage } \\
\text { area } \\
\left(\mathrm{mi}^{2}\right)\end{array}$ & $\begin{array}{c}\text { Channel } \\
\text { slope } \\
\text { (ft/ft) }\end{array}$ & $\begin{array}{l}{ }^{\text {aAverage }} \\
\text { overbank flow } \\
\text { velocity at } \\
\text { the bridge } \\
\text { (ft/s) }\end{array}$ & $\begin{array}{c}{ }^{\text {aAverage }} \\
\text { overbank flow } \\
\text { depth at } \\
\text { the bridge } \\
\text { (ft) }\end{array}$ & $\begin{array}{c}\text { Median } \\
\text { grain size } \\
(\mathrm{mm})\end{array}$ & $\begin{array}{l}\text { Measured } \\
\text { clear-water } \\
\text { contraction- } \\
\text { scour depth } \\
\text { (ft) }\end{array}$ & $\begin{array}{c}\text { Geometric } \\
\text { contraction } \\
\text { ratio }\end{array}$ \\
\hline \multicolumn{8}{|c|}{ South Carolina Piedmont (75 measurements) } \\
\hline Minimum & 11.0 & 0.00015 & 1.7 & 1.3 & $<0.062$ & 0.0 & 0.02 \\
\hline Maximum & $1,620^{\mathrm{b}}$ & 0.0029 & 5.8 & 20.5 & 0.99 & 4.5 & 0.96 \\
\hline \multicolumn{8}{|c|}{ South Carolina Coastal Plain (64 measurements) } \\
\hline Minimum & 26.3 & 0.00007 & 0.5 & 4.2 & $<0.062$ & 0.0 & 0.50 \\
\hline Median & 586.0 & 0.0004 & 2.0 & 6.6 & 0.17 & 1.8 & 0.84 \\
\hline
\end{tabular}

${ }^{a}$ Values were estimated from a one-dimensional water-surface profile model.

${ }^{\mathrm{b}}$ Approximately 97 percent of the study sites in the Piedmont have drainage areas less than $400 \mathrm{mi}^{2}$.

${ }^{\mathrm{c} A p p r o x i m a t e l y ~} 80$ percent of the study sites in the Coastal Plain have drainage areas less than $1,420 \mathrm{mi}^{2}$. 
flood plain elevation in the vicinity of the observed scour. The measurements were assumed to represent the maximum clear-water contraction-scour depth that has occurred at the bridge since construction. Because of clear-water scour conditions, infill sediments within the scour holes were, in general, negligible. A grab sample of the flood plain surface sediment was obtained in the upstream flood plain at each site and was analyzed to estimate the median grain size. Because sediment characteristics in the field setting can vary substantially in the vertical and horizontal direction, a grab sample taken at a point may not fully represent the sediment characteristics at a site. The overview of the historical flows as described in the report sections "Clear-Water Pier-Scour Envelope Curve" and "South Carolina Clear-Water Abutment Scour Field Data" provide information regarding the historic flows associated with the clear-water contraction-scour sites in the Coastal Plain and Piedmont, respectively, and reference can be made to those sections and appendix 2 to gain insight regarding flow conditions that likely created the measured scour. The South Carolina clear-water contraction-scour depths were measured during low flows, and the flow conditions that produced the scour are not known. As with the previously described pierand abutment-scour data, hydraulic characteristics that may have produced the observed contraction scour were estimated with the WSPRO (Shearman, 1990) model, assuming the 100 -year flow to be representative of a common flow that may have occurred at all bridges. The estimated hydraulic characteristics derived from the WSPRO model should be viewed as approximate rather than measured data.

\section{Clear-Water Contraction-Scour Envelope Curve}

As described in the report section "Clear-Water Abutment-Scour Envelope Curves With Respect to the Geometric-Contraction Ratio," the geometric-contraction ratio is an indicator of the severity of flow contraction created by a bridge. In general, as the geometric-contraction ratio increases, the flow velocity through a bridge opening increases, thereby increasing the potential for scour. Therefore, it is reasonable to expect an increase in clear-water contraction-scour depth with increasing geometric-contraction ratios. Using this concept, Benedict (2003) developed an envelope curve for the clear-water contraction-scour data collected in the Piedmont (table 13) by using the 100-year flow geometric-contraction ratio as the primary explanatory variable. Benedict and Caldwell (2006) expanded on the work by Benedict (2003) by combining the Piedmont and Coastal Plain data (table 13) and evaluating the upper bound of clear-water contraction scour for the larger dataset. The analysis yielded the envelope curve shown in figure 43 , which varied only slightly from the envelope curve developed by Benedict (2003). The equation associated with the envelope curve is as follows:

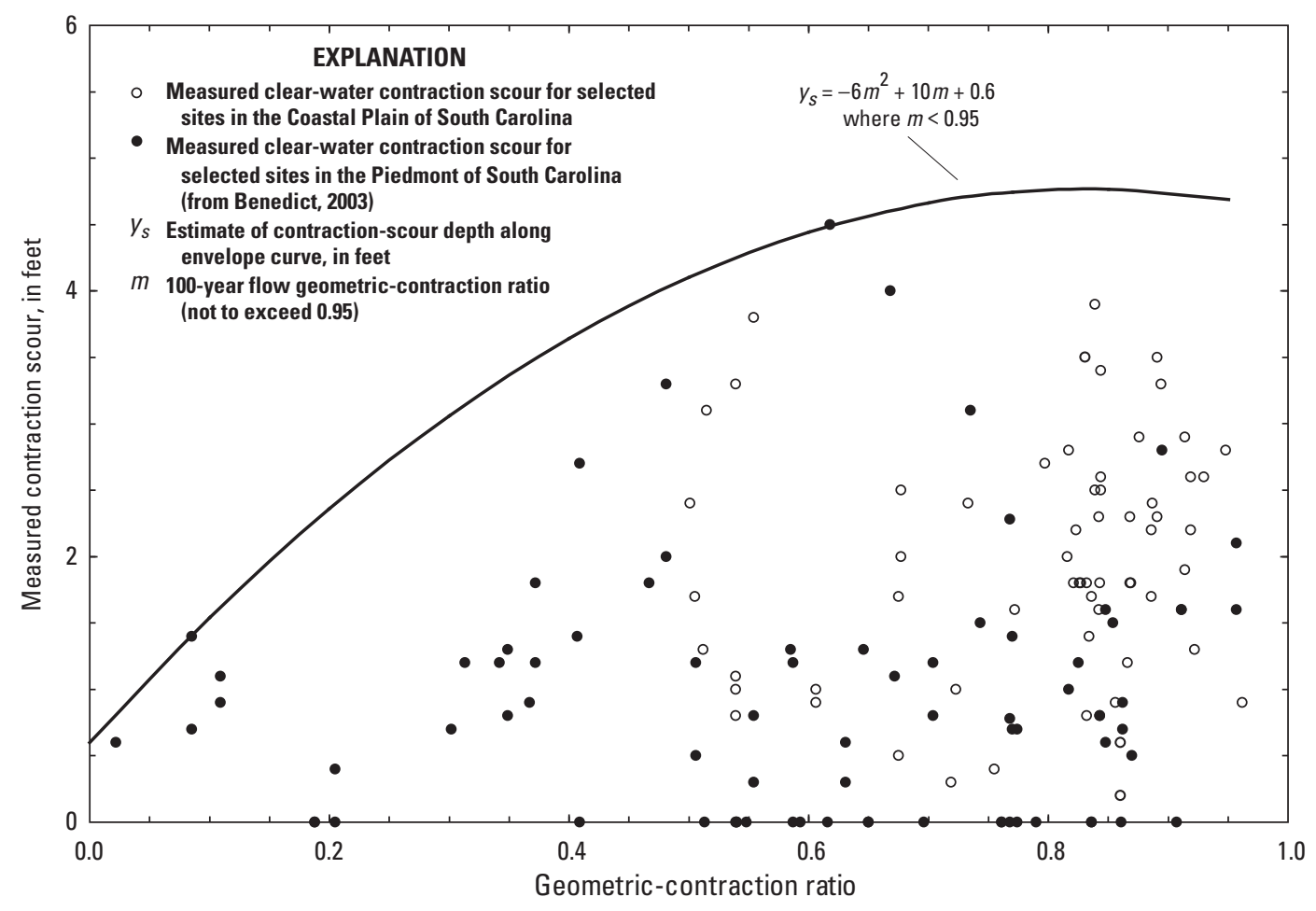

Figure 43. The South Carolina clear-water contraction-scour envelope curve for the Piedmont and Coastal Plain (from Benedict and Caldwell, 2006). 


$$
y_{s}=-6 m^{2}+10 m+0.6 \text {, }
$$

where

$$
\begin{gathered}
y_{s} \quad \begin{array}{c}
\text { is the upper bound for potential clear-water } \\
\text { contraction-scour depth, in feet; and }
\end{array} \\
m \quad \text { is the geometric-contraction ratio based } \\
\text { on the 100-year-flow (eq. 15). }
\end{gathered}
$$

On the basis of the limits of the Piedmont data, Benedict (2003) recommended limiting the application of the envelope curve equation to geometric-contraction ratios less than or equal to 0.85 . Because of the additional data from the Coastal Plain that exceed this value, Benedict and Caldwell (2006) noted that it may be reasonable to increase this limit to 0.95 . However, they noted that because data are sparse for geometric-contraction ratios between 0.90 and 0.95 , the equation should be used with caution within this range.

Clear-water abutment and contraction scour both can occur on the bridge overbank (fig. 23), with abutment scour generally occurring in close proximity to the abutment toe and the contraction scour occurring beyond the region of abutment scour. The abutment scour typically will be deeper than the contraction scour and at times substantially so. The velocity flow field at a bridge contraction, as illustrated in figure 22, provides some explanation for this pattern, with the largest velocities occurring in the abutment-scour region and diminishing with lateral distance from the abutment toe in the contraction scour region. A field example of the scour regions shown in figure 23 can be seen at structure 274000300200 on S.C. Route 3 crossing Cypress Creek in Jasper County (fig. 44). The bridge is $210 \mathrm{ft}$ long over a swampy channel similar to the conditions shown in figure 5. The left and right abutment-scour holes are 10.8 and $14.4 \mathrm{ft}$ deep, respectively, and are located in close proximity to the abutment toes. Beyond the abutment-scour holes, the clear-water contractionscour depth is substantially less, with a maximum depth of approximately $2 \mathrm{ft}$. The clear-water contraction-scour data collected in the Piedmont (Benedict, 2003) and the Coastal Plain (Benedict and Caldwell, 2006) of South Carolina were generally collected in the clear-water contraction-scour region, as defined in figures 23 and 44, outside the region of abutment scour. Because clear-water abutment-scour depths can be substantially larger than clear-water contraction-scour, it is important to differentiate these types of scour and the general regions of the overbank where they are most likely to occur (figs. 23 and 44) when applying the South Carolina clear-water contraction- and abutment-scour envelope curves.

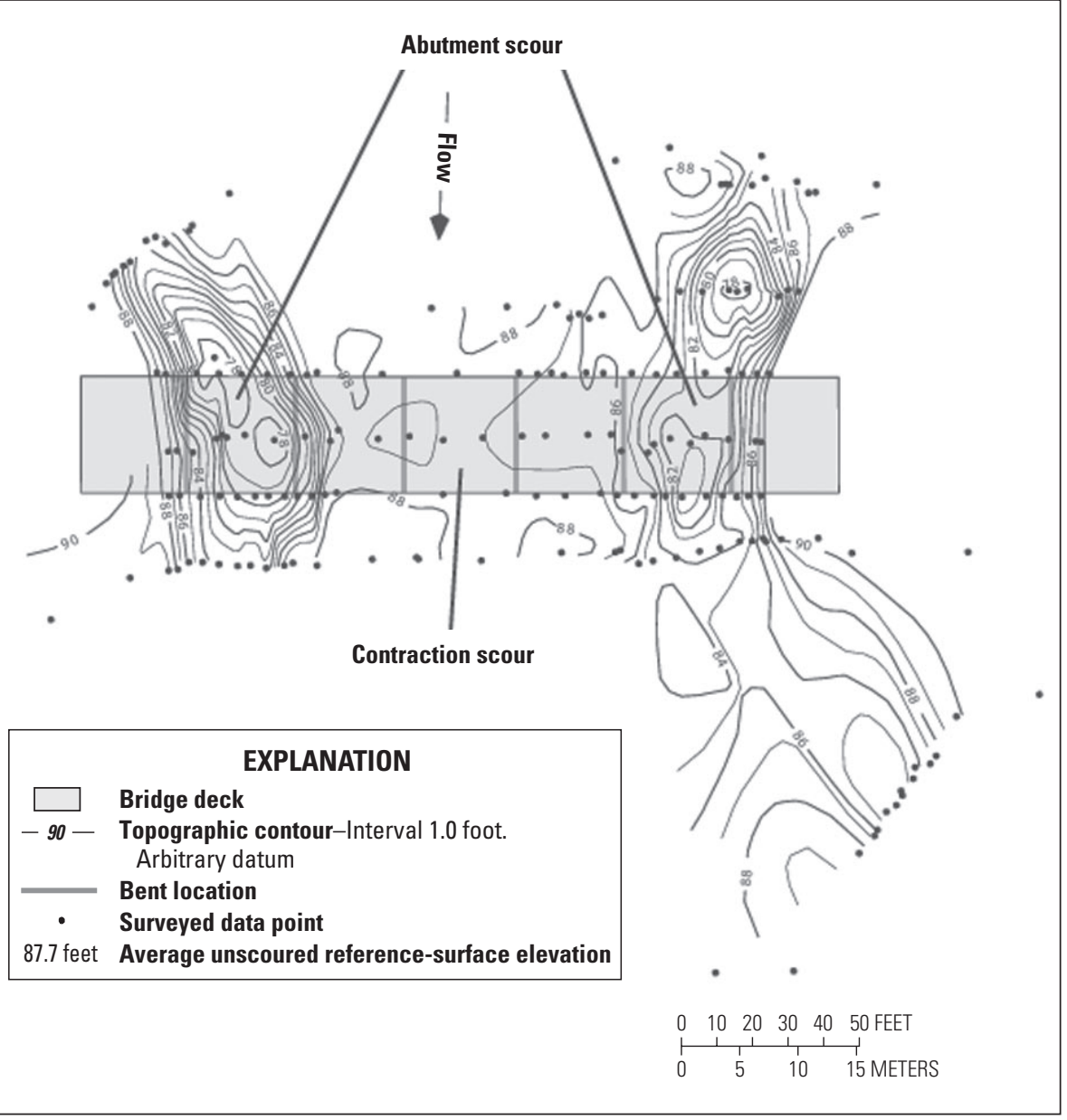

Figure 44. Example of clear-water abutment- and contraction-scour areas at structure 274000300200 on S.C. Route 3 crossing Cypress Creek in Jasper County (December 9, 1996; from Benedict and Caldwell, 2006). 


\section{Comparison of the South Carolina Clear-Water Contraction-Scour Envelope Curve With Other Data}

A literature review for field measurements of clear-water contraction scour identified several sources of data including the NBSD (U.S. Geological Survey, 2001) and the scour investigation in Alabama (Lee and Hedgecock, 2008). The NBSD included nine measurements of clear-water contraction scour on bridge overbanks. A review of the data indicated that the two measurements with the largest scour depths $(14 \mathrm{ft})$ were associated with scour in the abutment-scour region (fig. 23) and, therefore, would be better classified as abutment scour rather than contraction scour. The remaining seven measurements had contraction-scour depths ranging from 0.5 to $4.5 \mathrm{ft}$; however, only two of these measurements had supporting information for estimating the geometriccontraction ratio, and these data were selected (table 14) to compare with the South Carolina data. These two NBSD measurements were associated with relief bridges at a multiple-bridge crossing, cohesive sediments, and historical peak flows near the 100-year flow magnitude. The Alabama data included 37 measurements of clear-water contraction scour collected in the cohesive, flood plain sediments of the Black Prairie Belt of the Coastal Plain of Alabama (Lee and Hedgecock, 2008). As noted in the report section "Comparison of the South Carolina Clear-Water Abutment-Scour Envelope Curves With Other Data," most of the Alabama data were associated with short flood plain relief bridges or bridges crossing swampy channels (240 ft or less) making it appropriate to classify these data as clear-water abutment scour rather than clear-water contraction scour, as was done for such bridges in the South Carolina abutment-scour investigation (Benedict, 2003). However, seven measurements (table 14) in the Alabama data have bridge lengths greater than $240 \mathrm{ft}$ with lengths ranging from $246 \mathrm{ft}$ to $894 \mathrm{ft}$. Scour at such sites should represent clear-water contraction scour similar to the South Carolina data, making them appropriate for comparison. Lee and Hedgecock (2008) concluded that the Alabama bridge sites had historical peak flows that likely equaled or exceeded the 50-year flow magnitude. The NBSD and Alabama data represent historical scour measurements similar to the South Carolina data, and one-dimensional flow models were used to estimate the hydraulic properties. The post-flood nature of the scour measurements, in conjunction with the estimated hydraulics, makes these data less than ideal. These limitations should be kept in mind when using these field data in any analysis. Table 14 lists the median and range of selected site characteristics for the NBSD and Alabama field data. For additional details regarding these data, reference can be made to NBSD (U.S. Geological Survey, 2001) and Lee and Hedgecock (2008).

The NBSD and Alabama clear-water contraction-scour data (table 14) and the South Carolina field data (table 13) are plotted with the South Carolina clear-water contraction-scour envelope curve in figure 45. Most of the NBSD and Alabama data fall within the envelope curve, with the exception of one point that slightly exceeds the curve. Although the number of comparison data are small (table 14), the data provide some support that the South Carolina clear-water contraction-scour envelope curve is reasonable. The NBSD and Alabama data are associated with cohesive sediments, similar to the Piedmont data (table 13); therefore, the comparison in figure 45 is most applicable to the Piedmont data.

Table 14. Range of selected characteristics of clear-water contraction scour field data used for comparison with the South Carolina clear-water contraction-scour data.

$\left[\mathrm{mi}^{2}\right.$, square mile; ft/ft, foot per foot; ft/s, foot per second; ft, foot; mm, millimeter; NBSD, National Bridge Scour Database; —, not available ]

\begin{tabular}{|c|c|c|c|c|c|c|c|}
\hline $\begin{array}{l}\text { Range } \\
\text { value }\end{array}$ & $\begin{array}{c}\text { Drainage } \\
\text { area } \\
\left(\mathrm{mi}^{2}\right)\end{array}$ & $\begin{array}{l}\text { Channel } \\
\text { slope } \\
\text { (ft/ft) }\end{array}$ & $\begin{array}{l}\text { aAverage } \\
\text { overbank flow } \\
\text { velocity at } \\
\text { the bridge } \\
\text { (ft/s) }\end{array}$ & $\begin{array}{l}\text { a Average } \\
\text { overbank flow } \\
\text { depth at } \\
\text { the bridge } \\
\text { (ft) }\end{array}$ & $\begin{array}{l}\text { bMedian } \\
\text { grain size } \\
\quad(\mathrm{mm})\end{array}$ & $\begin{array}{l}\text { Measured } \\
\text { clear-water } \\
\text { contraction- } \\
\text { scour depth } \\
\text { (ft) }\end{array}$ & $\begin{array}{c}\text { Geometric } \\
\text { contraction } \\
\text { ratio }\end{array}$ \\
\hline \multicolumn{8}{|c|}{ NBSD (U.S. Geological Survey, 2001) (2 measurements) } \\
\hline Minimum & 1,327 & 0.000145 & - & - & 0.001 & 0.0 & 0.92 \\
\hline Maximum & 1,327 & 0.000145 & - & - & 0.001 & 4.5 & 0.92 \\
\hline \multicolumn{8}{|c|}{ Alabama (Lee and Hedgecock, 2008) (7 measurements) } \\
\hline Minimum & 9.55 & 0.0004 & 2.10 & 2.33 & 0.001 & 2.13 & 0.42 \\
\hline Median & 21.3 & 0.001 & 2.86 & 3.94 & 0.0041 & 2.71 & 0.76 \\
\hline
\end{tabular}

${ }^{a}$ Values were estimated from a one-dimensional water-surface profile model.

${ }^{\mathrm{b}}$ All sediments are cohesive. 


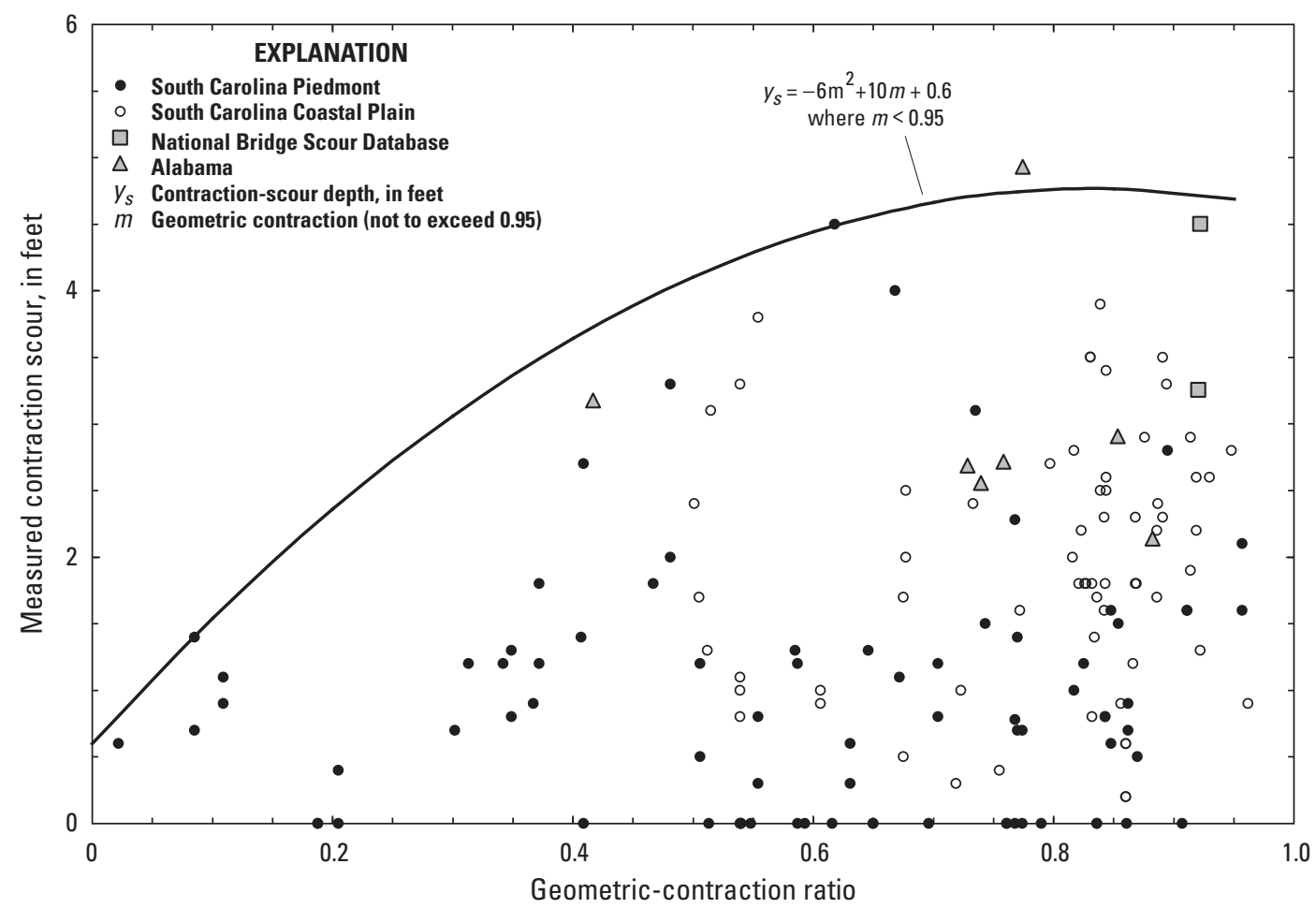

Figure 45. Comparison of the South Carolina clear-water contraction-scour envelope curve with field data from other sources.

\section{Relative Increase in Theoretical Clear- Water Contraction Scour Associated With the 100- to 500-Year Flows}

As previously described in the report sections "ClearWater Pier-Scour Envelope Curve" and "South Carolina Clear-Water Abutment-Scour Field Data," a substantial portion of the field data used to develop the South Carolina clear-water contraction-scour envelope curve included scour measurements likely associated with historic flows near the 100 -year flow magnitude. Therefore, the envelope curves can be used to assess scour potential for such flow conditions (Benedict and Caldwell, 2006). (Note: The contraction-scour envelope curves should not be considered a definitive estimate of the contraction-scour depth associated with the 100-year flow.) The South Carolina clear-water contraction-scour envelope curve, however, was not recommended for assessing scour potential for extreme floods such as the 500-year flow (Benedict and Caldwell, 2006). In order to gain insights on the relative increase in contraction-scour depth associated with the 100- to 500-year flows, a theoretical adjustment coefficient similar to those developed for pier scour (see report section "Relative Increase in Theoretical Pier Scour Associated With the 100- to 500-Year Flows") can be developed for clearwater contraction scour. Although such adjustments do not provide a definitive estimate of the 500 -year contraction-scour depth, the estimates do provide perspective on the relative increase. A summary of the compiled theoretical clear-water contraction-scour data and the analysis of the 500-year flow adjustment coefficient is presented below.

\section{Theoretical Clear-Water Contraction-Scour Data}

The South Carolina Theoretical Bridge Scour Database (http://dx.doi.org/10.3133/sir20165121), as previously described in the report section "Theoretical Pier-Scour Data," includes 309 theoretical clear-water contraction-scour depths for both the 100- and 500-year flows that were used to evaluate the 500-year flow adjustment coefficient. In addition to the South Carolina data, the Missouri level-2 data (Huizinga and Rydlund, 2004) included theoretical computations for 137 clear-water contraction-scour depths that were used as a means to confirm the trends of the South Carolina data. The Missouri data are available at http://pubs.usgs.gov/ sir/2004/5213/.

\section{The 500-Year Flow Adjustment Coefficient}

The relation of the theoretical clear-water contraction scour for the 100- and 500-year flows for the South Carolina and Missouri data is shown in figure 46, including trend lines through each dataset. Summary statistics for the data are provided in table 15 . The scatter about the trend line for the South Carolina data is small, and the coefficient of determination is high (0.94) indicating that there is a strong correlation in the data. The trend line through the Missouri data falls in close proximity to the South Carolina trend line indicating that 
Figure 46. Relation of the 100 and 500-year flow, theoretical clear-water contraction-scour depths for selected data from level-2 bridge-scour studies in South Carolina and Missouri.

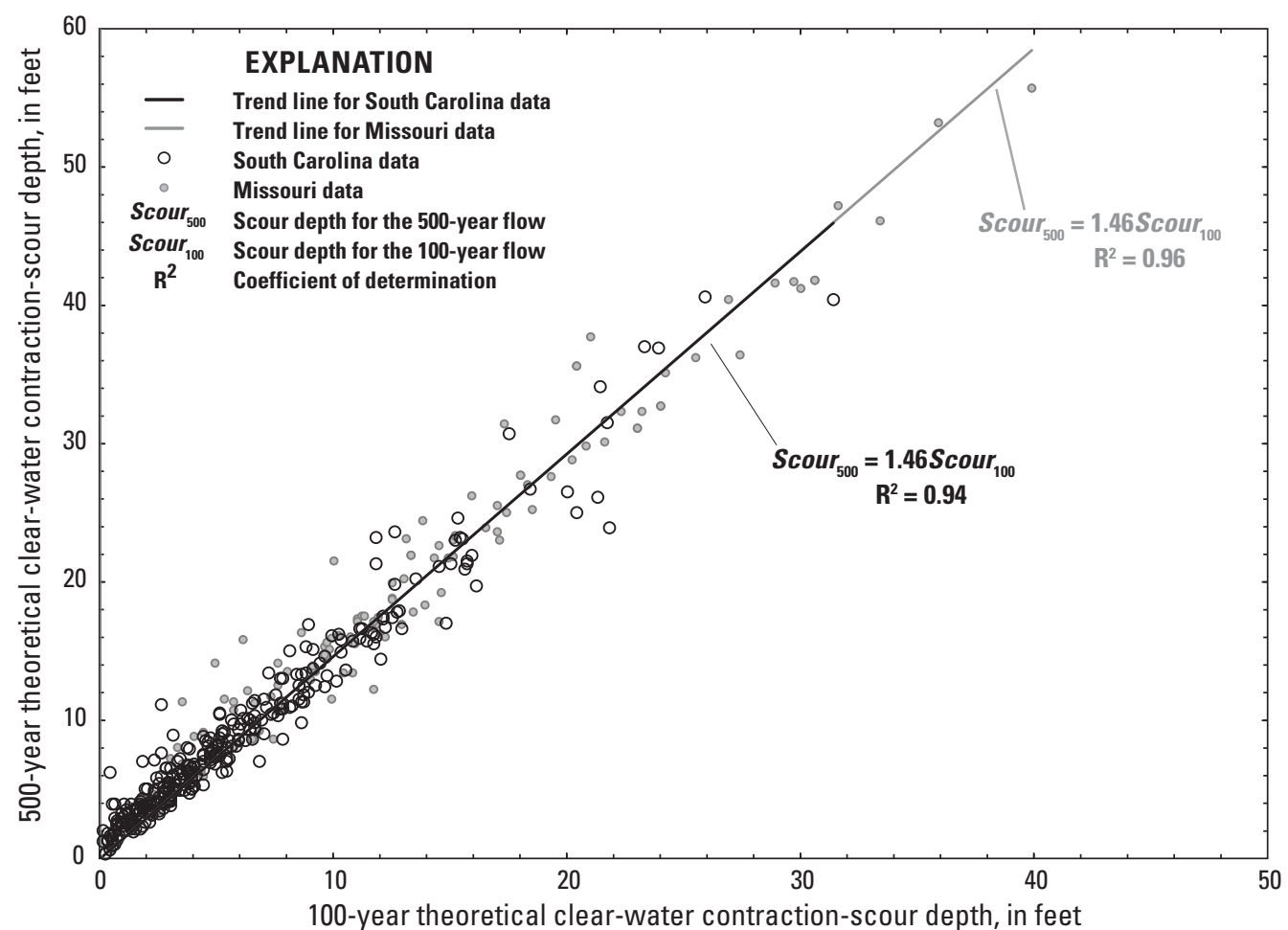

Table 15. Descriptive statistics for the ratio of the 500- and 100-year flow, theoretical clear-water contraction-scour depths used in the regression analysis for selected theoretical data from South Carolina and Missouri.

[N, number of measurements; Q500, 500-year flow; Q100, 100-year flow; $\mathrm{mi}^{2}$, square mile]

\begin{tabular}{|c|c|c|c|c|}
\hline \multirow{2}{*}{$\begin{array}{l}\text { Descriptive } \\
\text { statistic }\end{array}$} & \multicolumn{2}{|c|}{ South Carolina $(\mathrm{N}=309)$} & \multicolumn{2}{|l|}{ Missouri ( $N=137$ ) } \\
\hline & $\begin{array}{l}\text { Ratio of } 0500 \text { and } 0100 \text { theoretical } \\
\text { contraction-scour depths }\end{array}$ & $\begin{array}{l}\text { Drainage area } \\
\qquad\left(\mathrm{mi}^{2}\right)\end{array}$ & $\begin{array}{l}\text { Ratio of } 0500 \text { and } 0100 \text { theoretical } \\
\text { contraction-scour depths }\end{array}$ & $\begin{array}{l}\text { Drainage area } \\
\qquad\left(\mathrm{mi}^{2}\right)\end{array}$ \\
\hline Minimum & 1.03 & 4.12 & 1.00 & 3.70 \\
\hline 25 th percentile & 1.42 & 21.4 & 1.40 & 16.9 \\
\hline Mean & 1.96 & 286 & 1.63 & 158 \\
\hline Median & 1.60 & 52.4 & 1.50 & 34.3 \\
\hline 75th percentile & 1.87 & 174.0 & 1.65 & 159 \\
\hline Maximum & 20.0 & 8,312 & 4.33 & 1,790 \\
\hline
\end{tabular}

the South Carolina trend line is reasonable. The equation for the South Carolina trend line is

$$
\text { Scour }_{500}=1.46 \text { Scour }_{100}
$$

where

$$
\begin{gathered}
\text { Scour }_{500} \begin{array}{l}
\text { is the 500-year flow theoretical scour } \\
\text { depth, in feet; and }
\end{array} \\
\text { Scour }_{100} \text { is the } 100 \text {-year flow theoretical scour } \\
\text { depth, in feet. }
\end{gathered}
$$

Equation 21 can be divided by Scour $_{100}$ and simplified to the following form:

$$
K_{500}=1.46 \text {, }
$$

where $K_{500}$ is the theoretical 500-year flow adjustment coefficient that represents the ratio of the 500-year flow to 100 -year flow theoretical clear-water contraction-scour depths, and other variables are as previously defined. The $K_{500}$ coefficient can be applied to the South Carolina clear-water contractionscour envelope curve (fig. 46) to increase the contractionscour depth by the relative increase in theoretical clear-water contraction scour associated with the 100- to 500-year flow condition. The $K_{500}$ is a helpful tool for gaining perspective on the relative increase of theoretical scour associated with the 100 - to 500-year pier-scour depth. However, the adjusted envelope curve values should not be considered a definitive estimate of the contraction scour associated with the 500-year flow. 


\section{Application and Limitations of the South Carolina Clear-Water Contraction-Scour Envelope Curve}

The evaluation of clear-water contraction scour using the South Carolina contraction-scour envelope curves should be limited to sites having similar characteristics to those listed in table 13. The limitations of the envelope curves that were described in the previous sections should be followed carefully, and caution should be used when characteristics at a bridge approach the limits of the site characteristics used to develop the envelope curves. Because the envelope curves were developed from a limited sample of bridges in the Coastal Plain and Piedmont, scour depths could exceed the envelope curves; therefore, it may be prudent to apply a safety factor to the envelope curves. When using the envelope curves, it is critical to properly estimate the geometric-contraction ratio for the 100-year flow. To ensure that the geometric-contraction ratio is properly evaluated, various sources of data should be reviewed, including but not limited to topographic maps, hydraulic models, road plans, and field measurements. When discrepancies exist between these sources, judgment should be used to determine the most reasonable estimate of the geometric-contraction ratio. The geometric-contraction ratio was evaluated with the WSPRO flow model (Shearman, 1990; Arneson and Shearman, 1998) for the 100-year flow condition. To estimate the geometriccontraction ratio, the WSPRO model uses a standard location of the approach cross section at one bridge length upstream from the bridge, which represents the full, natural flood plain width with no adjustment for ineffective flow areas. (Note: The bridge hydraulics algorithm and associated cross sections in the HEC-RAS model [Brunner, 2016] differ from that of the WSPRO model, and when using the HEC-RAS model to estimate the geometric-contraction ratio, judgment must be used to assure that the estimates are comparable to those used in Benedict and Caldwell [2006], which were based on the WSPRO model. Guidance regarding this matter is presented in the report section "Guidance for Applying the South Carolina Bridge-Scour Envelope Curves.") The South Carolina clear-water contraction-scour envelope curve (fig. 43) was developed using field data from sites with flows approaching the 100-year flow but should not be interpreted as representing the "100-year" scour estimate and also should not be used to evaluate clear-water contraction-scour depths for extreme conditions, such as the 500-year flow. To gain insights on the relative change in the theoretical clear-water contractionscour depth associated with the 100 -year to 500-year flow, the 500-year scour coefficient (eq. 22) may be applied to the envelope curve estimate.

\section{Selecting a Reference Surface for Clear- Water Contraction Scour}

Benedict (2003) used the average, undisturbed flood plain elevation in the contraction-scour region (fig. 23) as the reference surface to determine the clear-water contraction scour depth for the South Carolina data, and this reference surface should be used when assessing clear-water contraction scour with the South Carolina clear-water contraction-scour envelope curves. The reference surface can be determined by reviewing flood plain elevations from SCDOT road and bridge plans, surveyed cross sections, and (or) site visit observations. In many cases, the flood plain in the region of the contraction scour is relatively flat so estimating an average flood plain elevation in the region of anticipated scour is not a difficult task. However, there can be cases where the flood plain slopes substantially in the lateral and (or) longitudinal direction making the determination of a reference surface more difficult. In such cases, judgment must be applied, bearing in mind that lower reference-surface elevations will produce lower scour-hole elevations.

\section{Pier Scour Within Clear-Water Contraction- Scour Areas}

Because of the shallow nature of clear-water contraction-scour holes, it generally was possible to distinguish the area of pier scour from the area of clear-water contraction scour. When collecting data at these sites, scour around piers generally was not included in the measurement of clear-water contraction scour. Therefore, the envelope curve shown in figure 43 represents contraction scour only and not total scour. These envelope curves can be used to evaluate anticipated ranges of clear-water contraction scour in Coastal Plain and Piedmont overbanks, but judgment must be used to account for any additional scour created by piers and pile bents. Guidance previously given in this report can be used to evaluate potential clear-water pier scour on bridge overbanks in the Coastal Plain and Piedmont.

A potential threat to overbank piers is channel widening (see Benedict [2003] for more details) or migration. Channel widening and migration can undermine overbank piers that are located near a channel bank. Therefore, it is important to evaluate overbank piers for the possibility of channel widening or migration. One should be aware of this potential problem and use judgment when evaluating scour at overbank piers or bents. Judgment also should be used if the effects of debris and (or) severe skews must be considered. 


\section{Estimate of Clear-Water Contraction-Scour Hole Location}

Benedict and Caldwell (2006) noted that the general shape of clear-water contraction-scour holes in the overbank region consists of shallow parabolic depressions running perpendicular to flow (fig. 23) and covering most of the overbank region unaffected by abutment scour. The low point of the scour hole typically is in close proximity to the roadway centerline beneath the bridge deck. The left and right lateral extent of the clear-water contraction scour typically begins at the edge of the abutment-scour hole and extends toward the bank. Scour depths over the lateral extent of the scour hole vary. It is reasonable to assume, however, that scour potential determined from the clear-water contraction-scour envelope curve (fig. 43) will occur under the bridge and will extend laterally from the edge of the abutment-scour hole to the channel bank. Because the edge of the abutment-scour hole is a limiting boundary for the clear-water contraction scour, abutment scour at the bridge should be evaluated first.

\section{The South Carolina Live-Bed Contraction-Scour Envelope Curves}

As noted previously, contraction scour occurs when increased flow velocities and vortexes, generated by a bridge contraction, cause the streambed to erode in the general region of the bridge. Contraction scour is classified as clear-water or live-bed, which refers to the sediment-transport conditions at the time of scour (Arneson and others, 2012). Live-bed contraction scour occurs when approach-flow velocities are sufficient to transport bed sediments into the scoured region. Equilibrium conditions for live-bed contraction scour are attained when bed-sediment transport into and out of the scoured region are at equilibrium. Live-bed contraction scour in South Carolina streams typically occurs in the main channel of a stream (fig. 4).

\section{South Carolina Live-Bed Contraction-Scour Field Data}

Benedict and Caldwell (2009) made 89 measurements of live-bed contraction scour in the main channel of selected bridges in South Carolina, with 35 measurements in the Piedmont and 54 in the Coastal Plain (table 16). Bridge sites where live-bed contraction-scour data were collected can be identified by referring to appendix 1 and figure 1. (Note: Twelve of the measurements were taken at secondary sites that were located near the primary bridge of interest. These secondary sites included old abandoned highway bridges, other highway bridges, or railroad bridges and are not included in the list of sites in appendix 1.) A grab sample of sediment from the channel bed surface was obtained in the upstream channel at each site and was analyzed to estimate the median grain size. Because sediment characteristics in the field setting can vary substantially in the vertical and horizontal direction, a grab sample taken at a point may not fully represent the sediment characteristics at a site. The data-collection sites for live-bed contraction scour also were part of the live-bed pier-scour investigation by Benedict and Caldwell (2009), and as with the live-bed pier-scour data, GPR was used to make

Table 16. Range of selected characteristics of live-bed contraction scour field data collected in the main channels of selected sites in South Carolina (Benedict and Caldwell, 2009).

$\left[\mathrm{mi}^{2}\right.$, square mile; $\mathrm{ft} / \mathrm{ft}$, foot per foot; $\mathrm{ft} / \mathrm{s}$, foot per second; $\mathrm{ft}$, foot; $\left(\mathrm{ft}^{3} / \mathrm{s}\right) / \mathrm{ft}$, cubic foot per second per foot; mm, millimeter]

\begin{tabular}{|c|c|c|c|c|c|c|c|c|c|c|}
\hline $\begin{array}{l}\text { Range } \\
\text { value }\end{array}$ & $\begin{array}{l}\text { Drainage } \\
\text { area } \\
\left(\mathrm{mi}^{2}\right)\end{array}$ & $\begin{array}{l}\text { Channel } \\
\text { slope } \\
\text { (ft/ft) }\end{array}$ & $\begin{array}{l}{ }^{\text {aAverage }} \\
\text { approach } \\
\text { velocity } \\
\text { (ft/s) }\end{array}$ & $\begin{array}{l}\text { aAverage } \\
\text { approach } \\
\text { flow } \\
\text { depth } \\
\text { (ft) }\end{array}$ & $\begin{array}{l}\text { Approach } \\
\text { channel } \\
\text { width } \\
\text { (ft) }\end{array}$ & $\begin{array}{l}\text { aUnit width } \\
\text { flow in } \\
\text { approach } \\
\text { channel } \\
\text { ([ft } / \text { s]/ft) }\end{array}$ & $\begin{array}{c}\text { Median } \\
\text { grain } \\
\text { size } \\
(\mathrm{mm})\end{array}$ & \multicolumn{2}{|c|}{$\begin{array}{l}\text { Measured contraction- } \\
\text { scour depth based on } \\
\text { estimate of scour } \\
\text { (ft) }\end{array}$} & $\begin{array}{l}\text { Geometric } \\
\text { contraction } \\
\text { ratio }\end{array}$ \\
\hline \multicolumn{11}{|c|}{ South Carolina Piedmont (35 measurements) } \\
\hline Minimum & 21 & 0.00015 & 2.4 & 7.7 & 41.0 & 19.5 & 0.51 & 0 & 2.8 & 0.14 \\
\hline Maximum & $5,250^{\mathrm{b}}$ & 0.0021 & 11.6 & 28.3 & 788.0 & 291.2 & 1.7 & 16.7 & 16.7 & 0.92 \\
\hline \multicolumn{11}{|c|}{ South Carolina Coastal Plain (54 measurements) } \\
\hline Minimum & 17.2 & 0.00007 & 1.1 & 4.7 & 21.0 & 6.7 & 0.18 & 0 & 2.7 & 0.29 \\
\hline Median & 521 & 0.00031 & 2.7 & 12.5 & 92.5 & 34.6 & 0.59 & 4.6 & 5.4 & 0.82 \\
\hline Maximum & $9,360^{c}$ & 0.002 & 7.1 & 39.0 & 785.0 & 267.5 & 1.7 & 17.1 & 17.1 & 0.95 \\
\hline
\end{tabular}

${ }^{a}$ Values were estimated from a one-dimensional water-surface profile model.

${ }^{\mathrm{b}}$ Approximately 94 percent of the study sites in the Piedmont have drainage areas less than $760 \mathrm{mi}^{2}$.

${ }^{\mathrm{c}}$ Approximately 80 percent of the study sites in the Coastal Plain have drainage areas less than $1,860 \mathrm{mi}^{2}$. 
these measurements during low-flow conditions. An overview of the use of GPR can be found in the report section "LiveBed Pier-Scour Envelope Curve," and an example of a GPR measurement of contraction scour that displays the remnant scour-hole bathymetry, as well as the sediment infill, is shown in figure 47. The overview of the historical flows and the estimate of hydraulic characteristics with the WSPRO (Shearman, 1990; Arneson and Shearman, 1998) model, as described in the report section "Live-Bed Pier-Scour Envelope Curve," also is applicable to the live-bed contraction-scour sites.

Benedict and Caldwell (2009) noted that the complex bed bathymetry often associated with the main channel of a stream, in conjunction with bed mobility, can make it difficult to define the live-bed contraction-scour depth. In particular, these characteristics can make it difficult to determine the most appropriate reference surface for estimating the depth of scour. (Benedict and Caldwell [2009] used the average thalweg elevation in the region of scour to estimate a reference surface. The thalweg is the lowest channel elevation at a given cross section.) Additionally, the complex bathymetry of the channel bed can make it difficult to isolate contraction scour caused by the bridge from scour caused by natural field conditions such as confluences, bends, natural channel constrictions, channel migration, debris, dune bedforms, and the natural thalweg meander. The difficulty of estimating live-bed contraction scour is further increased by the interpretive nature of GPR data. Although interpretation of GPR data often was conclusive, the determination of the sediment infill in some cases was unclear. In particular, for sites with relatively small geometric-contraction ratios ( 0.5 or less), there often was little evidence of remnant scour holes that identified where the historic contraction scour, if any, had previously occurred. The small contraction ratios, in conjunction with the limited evidence of remnant scour holes, indicated that substantial contraction scour likely had not occurred at such sites; however, the GPR data at these sites was at times ambiguous. At such sites, (8 measurements in the Coastal Plain and 19 in the Piedmont), Benedict and Caldwell (2009) made two estimates of live-bed contraction-scour depth, including (1) the "most likely estimate of measured scour" (referred to as the "most likely scour" for the remainder of the report), representing the interpreter's judgment of the maximum historic live-bed contraction scour that likely had occurred at that site, and (2) a more conservative interpretation of live-bed contraction scour called the "worst case estimate of measured scour" (referred to as the "worst case scour" for the remainder of the report) that assumed scour depth extended to the subsurface scour-resistant layer as identified in the GPR data and bridgeplan borings. Twenty-five of these sites had little evidence of contraction scour, and the "most likely scour" ranged from 0 to $3 \mathrm{ft}$. In contrast, the "worst case scour" at these 25 sites ranged from 2.8 to $11.6 \mathrm{ft}$. Benedict and Caldwell (2009) used the "most likely scour" in their development of the South Carolina live-bed contraction-scour envelope curves. Benedict and Caldwell (2009) noted that the challenges associated with assessing historical live-bed contraction scour, as previously described, introduce uncertainty and error into the South Carolina live-bed contraction-scour data. These limitations should be kept in mind when assessing the trends associated with these data. Additional information regarding the data limitations and the estimate of scour can be found in Benedict and Caldwell (2009).

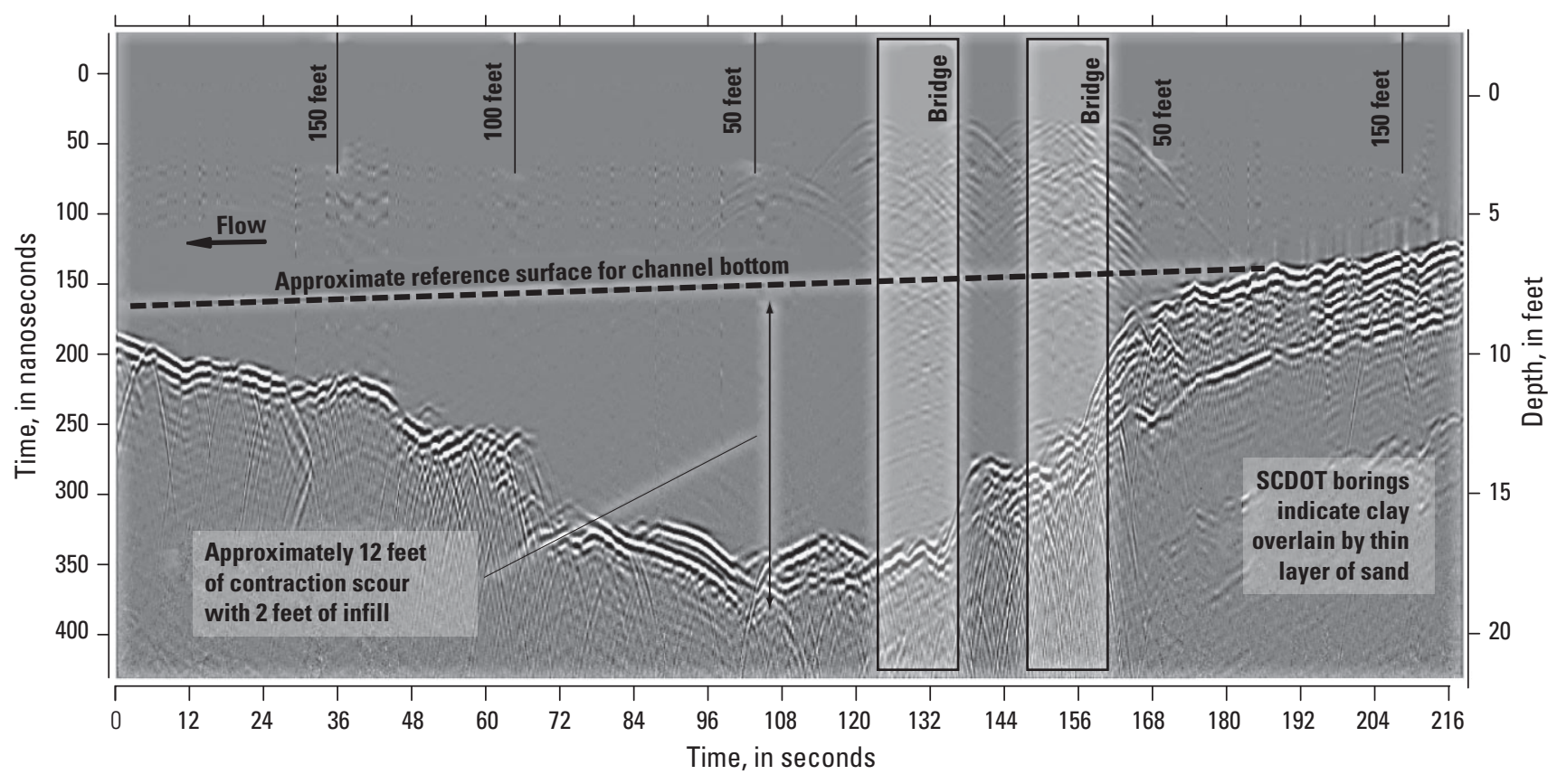

Figure 47. Example of ground-penetrating radar longitudinal profile at structure 262050110100 on U.S. Route 501 crossing the Little Pee Dee River in Horry County, South Carolina (from Benedict and Caldwell, 2009). Depth scale through sediments is unadjusted and approximate only. 


\section{Other Field Data}

Benedict and Caldwell (2009) used selected data from other sources to help confirm the trends observed in the South Carolina live-bed contraction-scour field data. These sources included the NBSD (U.S. Geological Survey, 2001), Hayes (1996), and Benedict (2003); table 17 lists the median and range of selected site characteristics for these data. Not all of the data from these sources could be used in the analysis, and Benedict and Caldwell (2009) provide details on the selected data. The selected NBSD measurements were associated with floods that were near to or exceeded the 100-year flow magnitude. (Note: One of the NBSD measurements was excluded in the dimensionless analysis by Benedict and Caldwell [2009] because of missing flow-depth data. However, the review of supporting files for that site during the current [2016] investigation identified the missing data, allowing it to be used in the current analysis.) The selected field data from Hayes (1996) included three measurements of live-bed contraction scour collected at the same bridge site, and the data were associated with flows ranging from approximately 50 to 60 percent of the 100-year flow magnitude. The geometric-contraction ratio for the Hayes (1996) data was modified from the published value of 0.29 to 0.6 based on topographic features at the site as described in Benedict and Caldwell (2009). In addition to the NBSD and Hayes (1996) data, 42 measurements of clear-water abutment scour selected from Benedict (2003) were used to help confirm the trends in the live-bed contraction-scour measurements. The selected data were associated with flood plain relief bridges or bridges over swampy channels with large contractions of flow, bridge lengths of approximately $240 \mathrm{ft}$ or less, and substantial scour that often created a single scour hole that encompassed the entire bridge opening. Although Benedict (2003) classified these data as clear-water abutment scour, technically the data are a form of clear-water contraction scour. Even though these are not live-bed scour data, they include some of the largest scour depths from the abutment-scour investigation, and Benedict and Caldwell (2009) used the data for perspective and limited confirmation. The data are referred to as clear-water contraction scour in this section of the report but should not be confused with the data used to develop the overbank clear-water contraction-scour envelope curve (fig. 43; table 13). A literature review was conducted for the current (2016) investigation to identify additional live-bed contractionscour data for comparison with the South Carolina live-bed contraction-scour envelope curves. However, no additional data that could be used in the comparison were identified.

\section{Live-Bed Contraction-Scour Envelope Curves}

Using a similar approach for the development of the South Carolina clear-water abutment- and contraction-scour envelope curves, Benedict and Caldwell (2009) used the geometric-contraction ratio as the primary explanatory variable to develop several envelope curves for the live-bed contraction-scour data. The envelope curves include dimensionless, or relative, scour depths, and the dimensional, or field scour depths, and are described below.

Table 17. Range of selected characteristics for field measurements of contraction scour used to help confirm the patterns of the South Carolina live-bed contraction-scour data (Benedict and Caldwell, 2009).

$\left[\mathrm{mi}^{2}\right.$, square mile; $\mathrm{ft} / \mathrm{ft}$, foot per foot; $\mathrm{ft} / \mathrm{s}$, foot per second; $\mathrm{ft}$, foot; $\left(\mathrm{ft} \mathrm{t}^{3} \mathrm{~s}\right) / \mathrm{ft}$, cubic foot per second per foot; $\mathrm{mm}$, millimeter; NBSD, National Bridge Scour Database; - , not available]

\begin{tabular}{|c|c|c|c|c|c|c|c|c|c|}
\hline $\begin{array}{l}\text { Range } \\
\text { value }\end{array}$ & $\begin{array}{c}\text { Drainage } \\
\text { area } \\
\left(\mathrm{mi}^{2}\right)\end{array}$ & $\begin{array}{l}\text { Channel } \\
\text { slope } \\
\text { (ft/ft) }\end{array}$ & $\begin{array}{l}\text { Average } \\
\text { approach } \\
\text { velocity } \\
\text { (ft/s) }\end{array}$ & $\begin{array}{c}\text { Average } \\
\text { approach } \\
\text { flow depth } \\
\text { (ft) }\end{array}$ & $\begin{array}{c}\text { Approach } \\
\text { channel } \\
\text { width } \\
\text { (ft) }\end{array}$ & $\begin{array}{l}\text { aUnit width } \\
\text { flow in } \\
\text { approach } \\
\text { channel } \\
\left(\left[\mathrm{ft}^{3} / \mathrm{s}\right] / \mathrm{ft}\right)\end{array}$ & $\begin{array}{l}\text { Median } \\
\text { grain size } \\
(\mathrm{mm})\end{array}$ & $\begin{array}{l}\text { Measured } \\
\text { contraction- } \\
\text { scour depth } \\
\text { (ft) }\end{array}$ & $\begin{array}{c}\text { Geometric } \\
\text { contraction } \\
\text { ratio }\end{array}$ \\
\hline \multicolumn{10}{|c|}{ Hayes (1996) and NBSD (U.S. Geological Survey, 2001) (12 measurements) } \\
\hline Minimum & 10.3 & - & 0.7 & 7.9 & 42 & 25.7 & 0.1 & 0 & 0.60 \\
\hline Maximum & 16,010 & - & 5.2 & 43 & 300 & 243 & 1.6 & 15 & 0.95 \\
\hline \multicolumn{10}{|c|}{${ }^{\mathrm{b} B}$ Benedict (2003) (42 measurements) } \\
\hline Minimum & 6.1 & 0.00015 & 0.05 & 2 & - & 0.4 & 0.06 & 0.9 & 0.77 \\
\hline Median & 32.2 & 0.001 & 0.5 & 4.3 & - & 2.1 & 0.2 & 9.6 & 0.91 \\
\hline
\end{tabular}

${ }^{a}$ This is the unit width flow on the approach flood plain for the Benedict (2003) data.

${ }^{\text {b}}$ The Benedict (2003) data were originally classified as abutment scour; however, the data are technically a form of clear-water contraction scour. These data represent some of the largest scour depths in Benedict (2003) and were used for perspective and limited confirmation of the patterns in the live-bed contraction-scour data.

${ }^{c}$ Approximately 95 percent of the clear-water sites have drainage areas less than 265 mi $^{2}$ (Benedict, 2003). 


\section{Dimensionless Live-Bed Contraction-Scour Envelope Curves}

Assuming a simple rectangular channel, comparable to a laboratory flume, Benedict and Caldwell (2009) simplified and rearranged the Laursen (1960) theoretical live-bed contractionscour equation to the following form:

$$
\frac{y_{s}}{y_{1}} \quad \frac{1}{1 m}{ }^{0.64}-1 \text {, }
$$

where

$$
\begin{aligned}
& y_{s} \quad \begin{array}{l}
\text { is the theoretical live-bed contraction- } \\
\text { scour depth, in feet; }
\end{array} \\
& y_{1} \quad \text { is the approach flow depth, in feet; and } \\
& m \quad \text { is the geometric-contraction ratio as } \\
& \quad \text { defined in equation } 15 .
\end{aligned}
$$

The quotient of the variables on the left side of the equals symbol in equation $23\left(y_{s} / y_{1}\right)$ is the dimensionless, or relative, live-bed contraction-scour depth, and the degree of contraction is expressed in terms of the geometric-contraction ratio $(m)$. The theoretical live-bed contraction-scour, $y_{s}$, can be obtained by multiplying the relative scour depth, $y_{s} / y_{1}$, by the appropriate approach flow depth, $y_{1}$. Figure $48 A$ shows the theoretical curve for equation 23, as well as the relative scour depths for the South Carolina, NBSD, and Hayes (1996) livebed contraction-scour data (tables 16, 17). Additionally, the selected clear-water contraction-scour data for the flood plain relief bridges or bridges over swampy channels (table 17), as described previously, are included. (Note: The additional NBSD data point not in the original analysis by Benedict and Caldwell [2009], as described previously, is shown in figure 48 with an $x-y$ plotting position of 0.93 and 1.42 , respectively.) The vertical axis represents scour depth normalized by the approach channel flow depth, and the horizontal axis represents the geometric-contraction ratio. The theoretical curve for equation 23 is essentially an envelope curve for the upper bound of the field data with only one data point exceeding the curve. The point that exceeds the curve is not excessive and is associated with a channel bend that will tend to increase scour depths, providing some explanation for its exceedance. The South Carolina clear-water contraction-scour data (table 17) are encompassed well by the dimensionless envelope curve defined by equation 23 (fig. 48A), providing limited support for the dimensionless envelope curve. The relative scour depths for the clear-water contraction-scour data tend to plot above the live-bed contraction-scour data. Benedict and Caldwell (2009) noted that the smaller flood plain flow depths used to normalize the clear-water contraction-scour data, in contrast to the channel flow depths used to normalize the livebed contraction-scour data, strongly contributes to this pattern. This pattern highlights how the relative-scour depth in equation 23 can be sensitive to the approach-flow depth, indicating the need to be cautious in selecting an appropriate estimate of flow depth for application to the equation. Although the clearwater contraction-scour data (table 17) provides some support for the dimensionless envelope curve for live-bed contractionscour (fig. 48A), it is difficult to make strong conclusions because of the differing nature of the clear-water contractionand live-bed contraction-scour data.

Figure $48 B$ only shows the live-bed contraction-scour data along with the dimensionless envelope curves for the Coastal Plain and Piedmont as presented in Benedict and Caldwell (2009). The equations for these dimensionless envelope curves are presented below.

Coastal Plain live-bed contraction-scour equation:

$$
\frac{y_{s}}{y_{1}} \quad 1.27 m^{2} \quad 0.43 m
$$

Piedmont live-bed contraction-scour equation:

$$
\frac{y_{s}}{y_{1}} \quad 1.21 m^{2} \quad 0.19 m
$$

where $y_{s}$ is the upper bound of potential live-bed contractionscour data, in feet, and the other variables are as defined in equation 23. The upper bound for potential live-bed contraction-scour, $y_{s}$, for equations 24 and 25 can be obtained by multiplying the relative scour depth, $y_{s} / y_{1}$, by the appropriate approach flow depth, $y_{1}$. In general, the upper bound of the South Carolina data fall near the simplified Laursen (1960) equation (eq. 23) for geometric-contraction ratios of about 0.5 or less but begin to fall below equation 23 as values increase beyond 0.5 . Perhaps one reason for this pattern is that the subsurface, scour-resistant layers can impede or limit scour, which is described in more detail later in the report. As noted previously, the one Coastal Plain data point that exceeds the dimensionless envelope curve is associated with a channel bend that will tend to increase scour depths. The dimensionless envelope curves indicate that the upper bound of relative scour for the Coastal Plain data exceeds that of the Piedmont. Benedict and Caldwell (2009) note that the reason for this pattern is uncertain but suggest that the differing field characteristics between these regions may contribute in some measure. In particular, the Coastal Plain tends to have longer flow durations, a higher frequency of bridges with large flow contractions, and subsurface sediment layers that are more susceptible to scour than the subsurface bedrock commonly associated with Piedmont streams. These characteristics will tend to produce larger scour depths in the Coastal Plain. Although the amount of data from Hayes (1996) and the NBSD (table 17) is small (only 9 of the 12 measurements could be used), all the data fall within the envelope curves, thus providing some support for the curves.

The dimensionless envelope curves shown in figure 48 and their associated equations (eqs. 23-25) can be used to help assess live-bed contraction-scour potential in the 


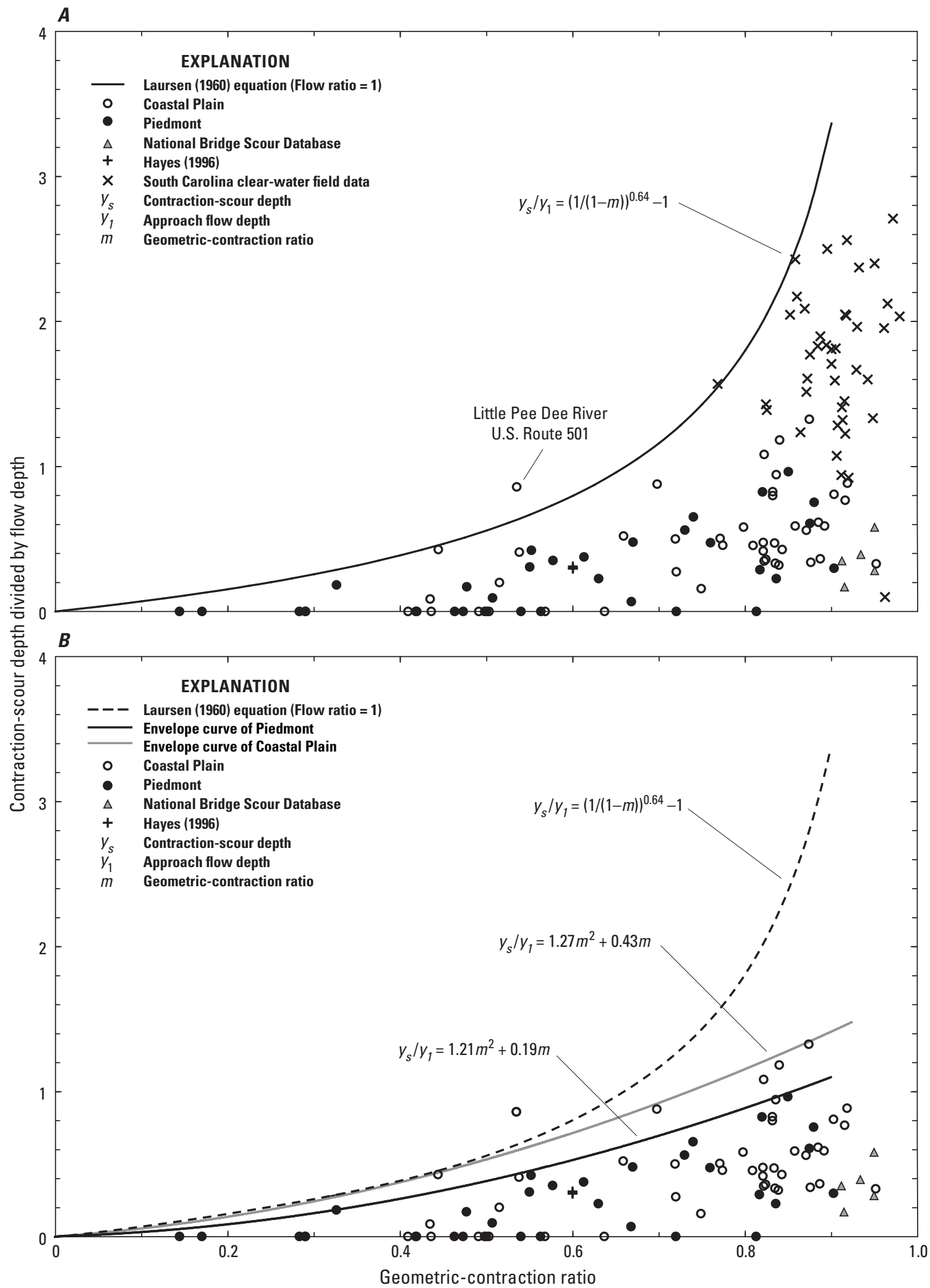

Figure 48. The South Carolina dimensionless live-bed contraction-scour envelope curve for $(A)$ livebed and clear-water contraction-scour data, and $(B)$ live-bed contraction-scour data only (modified from Benedict and Caldwell, 2009). 
Coastal Plain and Piedmont of South Carolina. Equation 23 reflects the Laursen (1960) theoretical equation for live-bed contraction scour by using the simplifying assumption of a rectangular channel and is a general equation that can be applied to assessing live-bed contraction-scour potential. Equations 24 and 25 reflect the trends for the upper bound of the field data for the Coastal Plain and Piedmont, respectively, and can be used to refine the assessment of scour potential for sites within those regions. The upper bound of the field data for the Coastal Plain and Piedmont (fig. 48B) have geometriccontraction ratios limited to approximately 0.87 and 0.85 , respectively; therefore, the application of equations 24 and 25 beyond these values is questionable. In general, the application of these equations should be used with caution and should be limited to sites that have characteristics well within the range of the South Carolina live-bed contraction-scour data used to develop the dimensionless envelope curves (table 16). Because of the limited nature of the NBSD and Hayes (1996) data, the characteristics associated with those data (table 17) should not be used to extend the application limits of the equations. As noted previously, relative scour depth as defined in equations 23-26 is sensitive to the selection of the approach-flow depth $\left(y_{1}\right)$, indicating the need to be cautious in selecting this variable for application to the envelope curves.

\section{Field Envelope Curve for Live-Bed Contraction Scour}

Similar to the dimensionless envelope curves (fig. 48), Benedict and Caldwell (2009) developed a field envelope curve for the dimensional form of the live-bed contractionscour data, using the geometric-contraction ratio as the explanatory variable (fig. 49). Figure $49 A$ includes the live-bed contraction-scour data for South Carolina, NBSD, and Hayes (1996). In the development of the dimensionless live-bed contraction-scour envelope curve (fig. 48), differences in the upper bound of the Coastal Plain and Piedmont data were sufficient to justify separate envelope curves. However, Benedict and Caldwell (2009) concluded that regional envelope curves could not be justified for the data patterns shown in figure $49 A$ and used a single envelope curve to encompass all of the data. The equation for the field envelope curve of live-bed contraction scour is as follows:

$$
y_{s}=24.7 m^{2}+1.3 m,
$$

where $y_{s}$ is the upper bound of potential live-bed contractionscour data, in feet, and $m$ is as previously defined. The two Coastal Plain measurements that exceed the envelope curve are associated with channel bends that will increase the potential for scour, providing some explanation for their exceedance. Additionally, the one Piedmont measurement that exceeds the curve is associated with substantial debris, which likely causes the exceedance. Although the amount of data from Hayes (1996) and the NBSD (table 17) is small (11 of the 12 measurements could be used), all the data fall within the envelope curve, thus providing some support for the curve. Figure $49 B$ shows the same data in figure $49 A$, but includes the clear-water contraction-scour data (table 17). Even though the clear-water contraction-scour data differ in nature from the live-bed contraction-scour data, they conform well to the live-bed contraction-scour envelope curve, suggesting that the curve is reasonable.

Figure 50 shows the South Carolina data and envelope curve for the "worst case scour." These data include the same data as figure $49 \mathrm{~A}$, but substitute the "worst case scour" at the 27 measurements previously described. For comparison, the envelope curve for the "most likely scour" from figure $49 \mathrm{~A}$ also is included in figure 50. Benedict and Caldwell (2009) developed an envelope curve for the "worst case scour" by adding a value of $5.5 \mathrm{ft}$ to equation 26 . The two "worst case scour" data that substantially exceed the "worst case scour" envelope curve (fig. 50) were purposely excluded because they are associated with small geometric-contraction ratios less than 0.3 where substantial contraction scour would not be anticipated. Benedict and Caldwell (2009) also noted that the "worst case scour" data that exceed the "most likely scour" envelope curve are associated with smaller geometriccontraction ratios (approximately 0.5 or less) where substantial contraction scour would not be anticipated, suggesting that the "worst case scour" estimates are likely over estimating the actual scour depths. Although Benedict and Caldwell (2009) acknowledge the uncertainty of the live-bed contraction-scour data on the basis of the observation above and the fact that the verification data from table 17 all fall within the "most likely scour" envelope curve (fig. 49), they conclude that the "most likely scour" data and the associated envelope curve shown in figure $49 \mathrm{~A}$ appear to be the more reasonable representation of live-bed contraction scour in South Carolina. The Coastal Plain and Piedmont data for the envelope curve in figure $49 \mathrm{~A}$ have geometric-contraction ratios limited to approximately 0.82 , indicating that the application of equation 26 beyond this value is questionable. Although the clear-water contractionscour data (fig. $49 \mathrm{~B}$ ) suggest that it may be appropriate to extend the envelope curve beyond a geometric-contraction ratio of 0.82 , the differing nature of the clear-water contraction- and live-bed contraction-scour data makes it difficult to make a strong conclusion, and any extension of equation 26 beyond a geometric-contraction ratio of 0.82 should be used with caution. In general, the application of equation 26 should be used with caution and limited to sites well within the range of the data used to develop the envelope curves.

\section{The Modified Live-Bed Contraction-Scour Envelope Curve}

Using selected field data from tables 16 and 17 (excluding the Hayes [1996] data), Benedict and Caldwell (2012) noted that the upper bound of clear-water and live-bed contraction scour increases with increasing drainage area (fig. 51). This upper-bound pattern is distinct in the clear-water and NBSD data. Two outliers in the South Carolina live-bed 


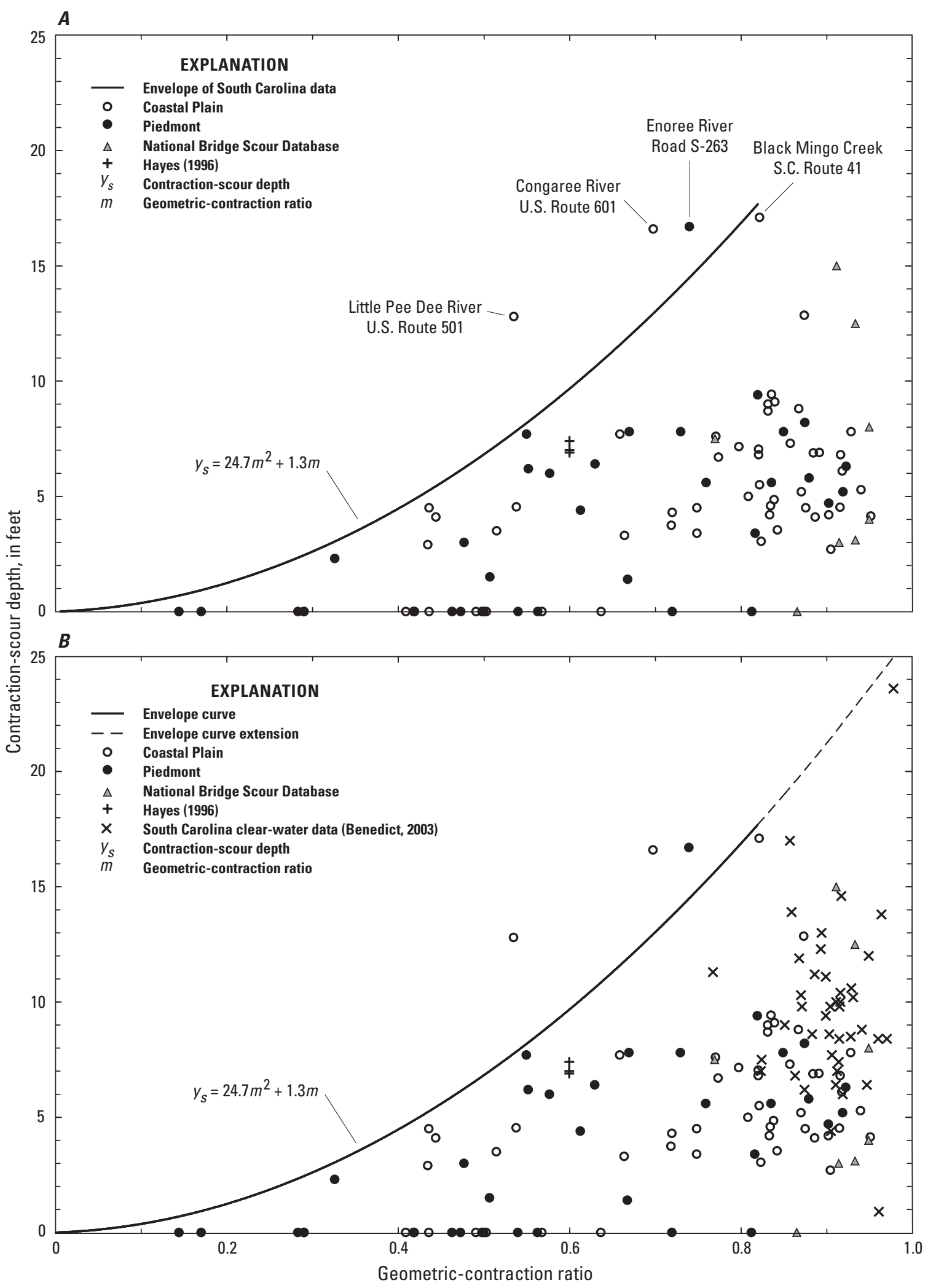

Figure 49. The South Carolina live-bed contraction-scour envelope curve for $(A)$ live-bed contractionscour data, and $(B)$ live-bed and clear-water contraction-scour data (from Benedict and Caldwell, 2009). 


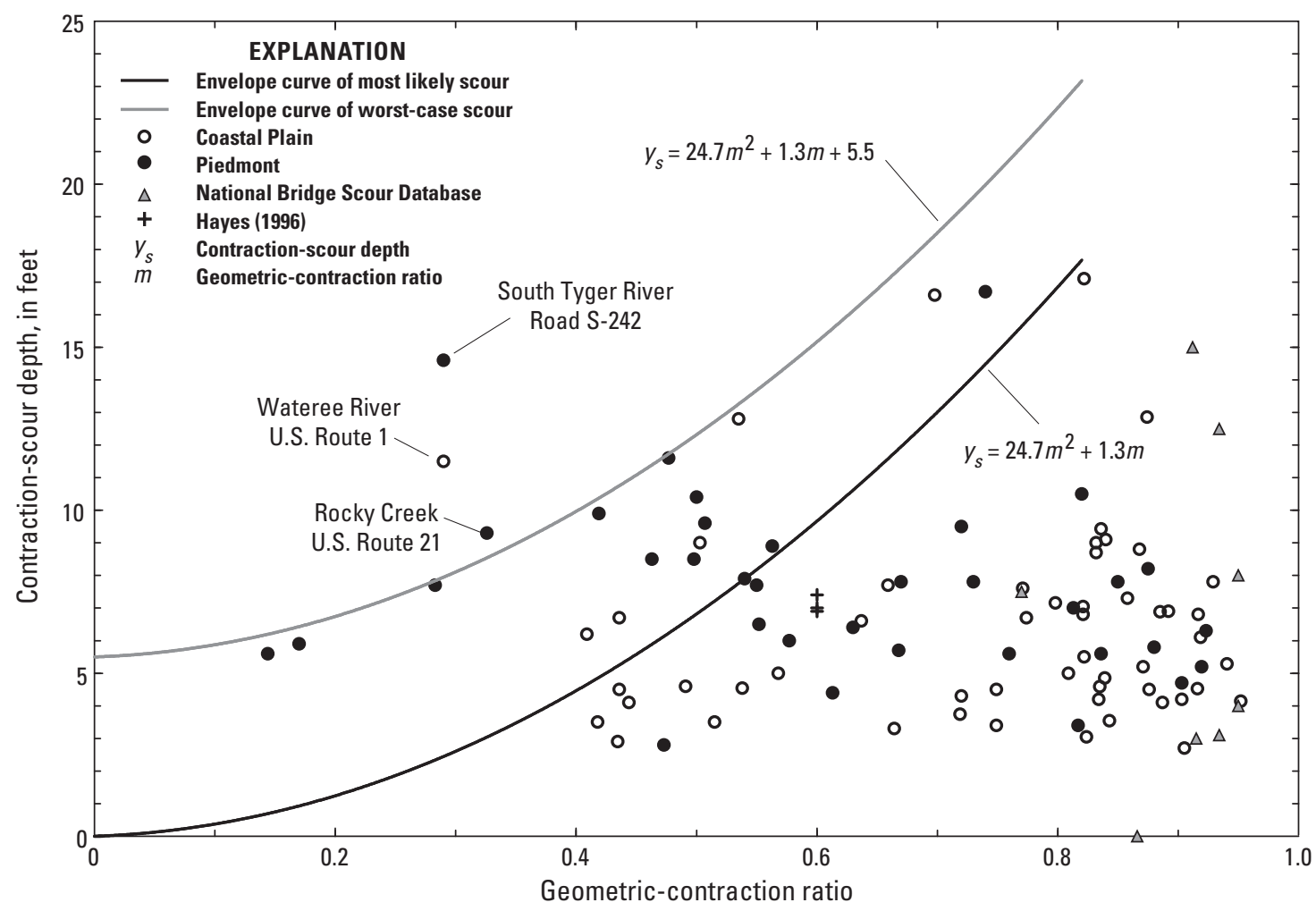

Figure 50. The South Carolina live-bed contraction-scour envelope curve for the "worst case scour" for the live-bed contraction-scour data (from Benedict and Caldwell, 2009).

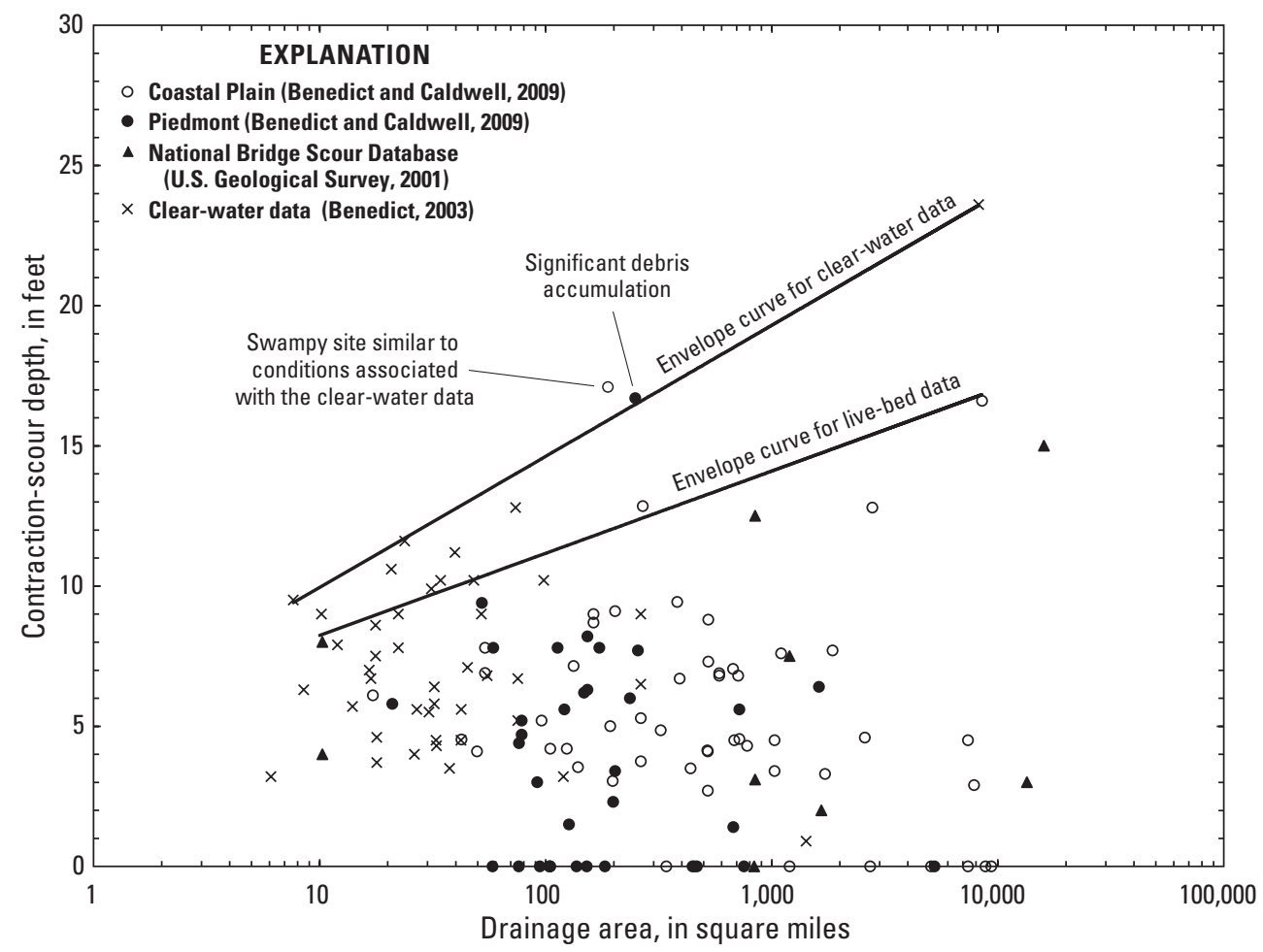

Figure 51. Relation of contraction-scour depth to drainage area for selected field data (modified from Benedict and Caldwell, 2012). 
contraction-scour data exceed the envelope curve for the live-bed data, but fall near the clear-water contraction-scour envelope curve (fig. 51). These two data points are associated with substantial debris accumulation or swampy conditions similar to the clear-water scour data, providing some explanation of their exceedance of the other live-bed contraction-scour data. Excluding these two data points, the upper bound of the South Carolina live-bed contraction-scour data show a similar pattern of increasing scour depth with increasing drainage area. It is notable that a similar pattern is observed in the upper bound of the abutment-scour data (fig. 40), providing support that the upper bound patterns in figure 51 are reasonable. The reasons for this pattern are not fully understood; however, Benedict and Caldwell (2012) suggested that smaller drainage basins tend to have shorter flow durations and thinner layers of channel alluvium sediments deposited over subsurface scour-resistant materials, both of which may contribute to smaller contraction-scour depths. On the basis of the abovenoted patterns of the field data, it was concluded that the South Carolina live-bed contraction-scour envelope curve could be modified to form a family of curves (secondary or modified envelope curves) with field data grouped by categories of drainage area. A review of the field data identified two categories including sites with drainage areas less than or equal to $100 \mathrm{mi}^{2}$ and sites with drainage areas greater than $100 \mathrm{mi}^{2}$ but less than or equal to $200 \mathrm{mi}^{2}$. Plots of these grouped data and their associated envelope curves are shown in figure 52 . Figure $52 B$ includes the data from both drainage area categories. The data used to develop the modified envelope curves are shown in table 18. The full family of curves is shown in figure 53 , and the equations for these curves are shown in table 19.

The application of the modified live-bed contractionscour envelope curves is limited to geometric-contraction ratios less than or equal to 0.90 for the modified envelope curves and 0.82 for the original curve. Additional details regarding the development of the South Carolina modified live-bed contraction-scour envelope curves can be found in Benedict and Caldwell (2012). Application and limitations of equations in table 19 are described in more detail in the report section "Application and Limitations of the South Carolina Live-Bed Contraction-Scour Envelope Curves."

Table 18. Range of selected site characteristics for field measurements of contraction scour used to develop the modified live-bed contraction-scour envelope curves (from Benedict and Caldwell, 2012).

$\left[\mathrm{mi}^{2}\right.$, square mile; ft/ft, foot per foot; ft/s, foot per second; ft, foot; mm, millimeter; NBSD, National Bridge Scour Database]

\begin{tabular}{|c|c|c|c|c|c|c|c|c|}
\hline $\begin{array}{l}\text { Range } \\
\text { value }\end{array}$ & $\begin{array}{c}\text { Drainage } \\
\text { area } \\
\left(\mathrm{mi}^{2}\right)\end{array}$ & $\begin{array}{l}\text { Channel } \\
\text { slope } \\
\text { (ft/ft) }\end{array}$ & $\begin{array}{c}\text { Average } \\
\text { approach } \\
\text { velocity } \\
\text { (ft/s) }\end{array}$ & $\begin{array}{c}\text { Average } \\
\text { approach } \\
\text { flow depth } \\
\text { (ft) }\end{array}$ & $\begin{array}{l}\text { Approach } \\
\text { channel } \\
\text { width } \\
\text { (ft) }\end{array}$ & $\begin{array}{c}\text { Geometric } \\
\text { contraction } \\
\text { ratio }\end{array}$ & $\begin{array}{l}\text { Median } \\
\text { grain size } \\
(\mathrm{mm})\end{array}$ & $\begin{array}{l}\text { Measured } \\
\text { contraction-scour } \\
\text { depth based } \\
\text { on most likely } \\
\text { estimate of scour } \\
\text { (ft) }\end{array}$ \\
\hline \multicolumn{9}{|c|}{ South Carolina Piedmont (24 measurements) } \\
\hline Median & 105 & 0.0012 & 5.5 & 13.7 & 72.5 & 0.64 & 0.77 & 3.7 \\
\hline Maximum & 199 & 0.0021 & 8.8 & 18.1 & 210 & 0.92 & 1.7 & 9.4 \\
\hline \multicolumn{9}{|c|}{ South Carolina Coastal Plain (15 measurements) } \\
\hline Minimum & 17.2 & 0.00013 & 1.3 & 5.2 & 21 & 0.44 & 0.23 & 3.1 \\
\hline Median & 124 & 0.00074 & 2.5 & 9.5 & 53 & 0.84 & 0.59 & 5.2 \\
\hline Median & 30.9 & 0.00076 & $0.5^{\mathrm{a}}$ & $5.4^{\mathrm{b}}$ & Flood plain & 0.91 & 0.22 & 6.8 \\
\hline Maximum & 120 & 0.0024 & $0.9^{\mathrm{a}}$ & $8.0^{\mathrm{b}}$ & Flood plain & 0.97 & 0.78 & 12.8 \\
\hline \multicolumn{9}{|c|}{ NBSD (2 measurements) } \\
\hline Minimum & 10.3 & 0.001 & 0.7 & 13.8 & 42 & 0.95 & 0.1 & 4 \\
\hline Maximum & 10.3 & 0.001 & 1 & 14.2 & 42 & 0.95 & 0.1 & 8 \\
\hline
\end{tabular}

aThese sites are associated with swampy flood plains with shallow, poorly defined channels; the average approach flow velocity was determined on the basis of the average approach flood plain velocity.

${ }^{\mathrm{b}}$ These sites are associated with swampy flood plains with shallow, poorly defined channels; the average approach flow depth was determined on the basis of the average approach flood plain depth. 


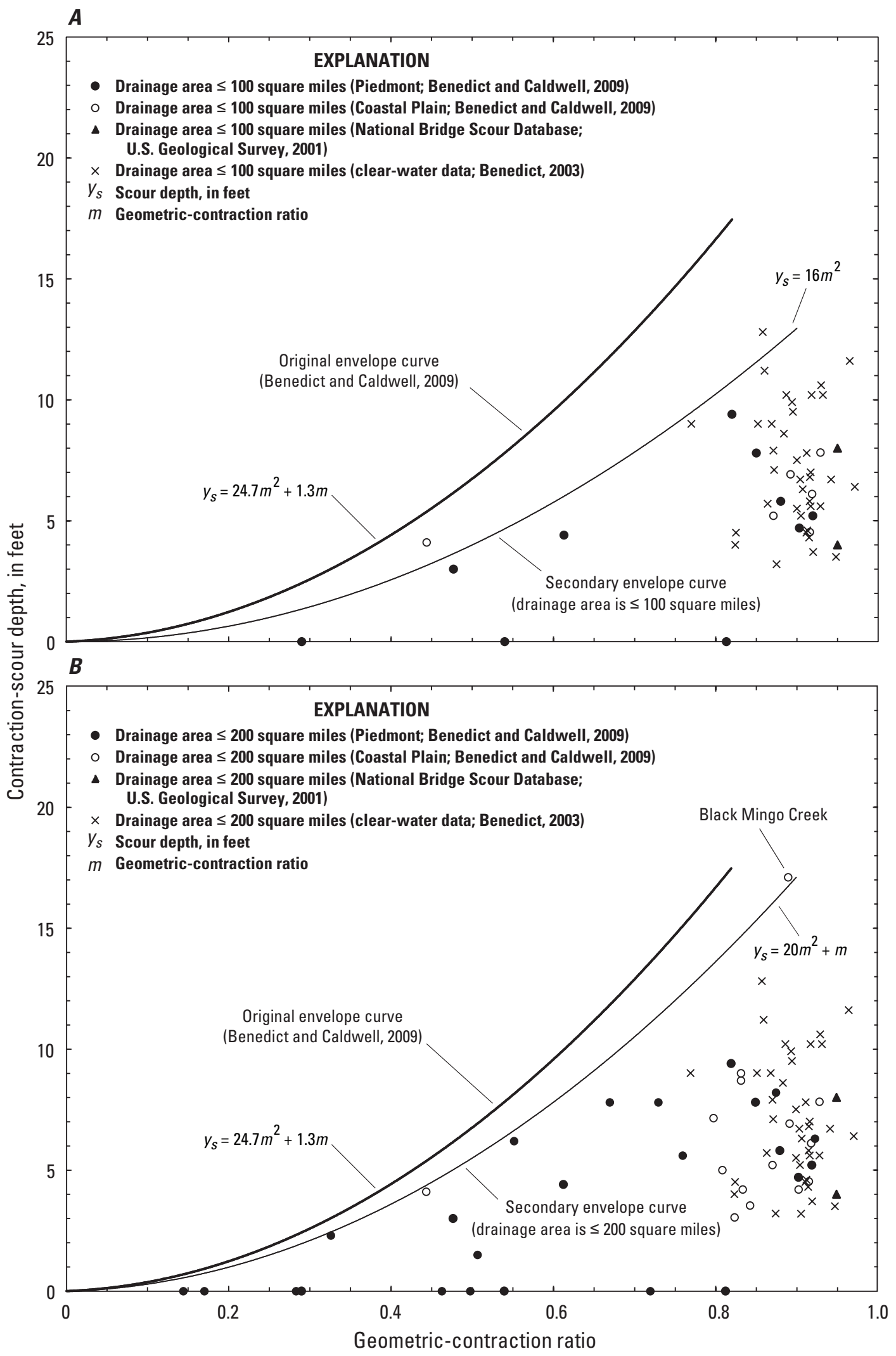

Figure 52. Relation of live-bed contraction-scour depth to the geometric-contraction ratio for selected field data for $(A)$ drainage areas 100 square miles or less, and $(B)$ drainage areas 200 square miles or less (modified from Benedict and Caldwell, 2012). 
Figure 53. Relation of live-bed contraction-scour depth to the geometric-contraction ratio for selected categories of drainage area for selected data in the Piedmont and Coastal Plain of South Carolina (from Benedict and Caldwell, 2012).

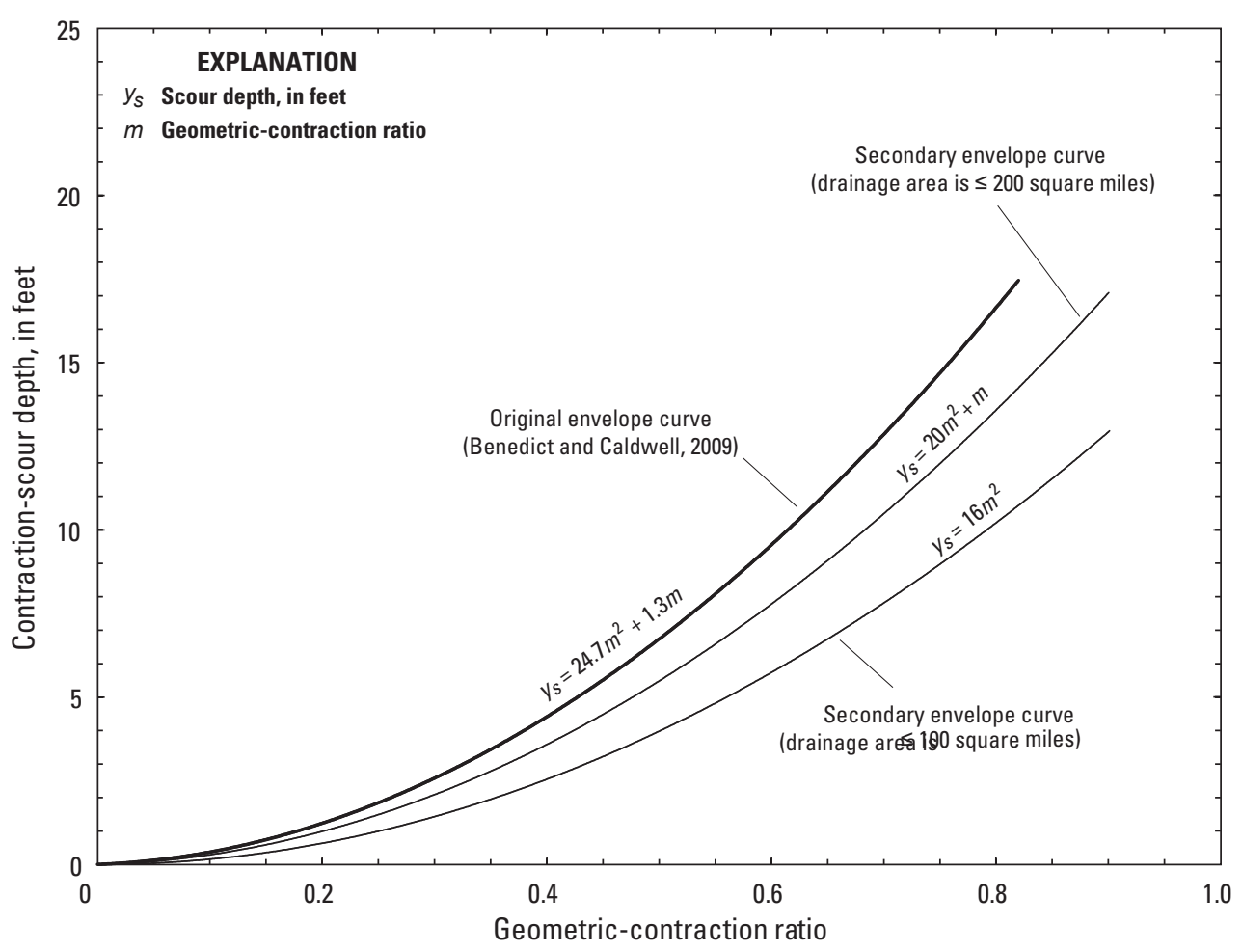

Table 19. Equations used to develop the modified live-bed contraction-scour envelope curve in the Piedmont and Coastal Plain of South Carolina.

$\left[\mathrm{mi}^{2}\right.$, square mile; $\leq$, less than or equal to; $D A$, drainage area; $y_{s}$, scour depth, in feet; $m$, geometric-contraction ratio; $<$, less than; $>$, greater than]

\begin{tabular}{clc}
\hline $\begin{array}{c}\text { Drainage-area } \\
\text { category }\end{array}$ & \multicolumn{1}{c}{ Equation } & $\begin{array}{c}\text { Limits of the } \\
\text { geometric- } \\
\text { contraction ratio }\end{array}$ \\
\hline $0 \mathrm{mi}^{2} \leq D A \leq 100 \mathrm{mi}^{2}$ & $y_{s}=16 m^{2}$ & $0 \leq m \leq 0.9$ \\
$100 \mathrm{mi}^{2}<D A \leq 200 \mathrm{mi}^{2}$ & $y_{s}=20 m^{2}+m$ & $0 \leq m \leq 0.9$ \\
$D A>200 \mathrm{mi}^{2}$ & $y_{s}=24.7 m^{2}+1.3 m$ & $0 \leq m \leq 0.82$ \\
\hline
\end{tabular}

\section{Relative Increase in Theoretical Live-Bed Contraction Scour Associated With the 100- to 500-Year Flows}

As previously described in the report section "LiveBed Pier-Scour Envelope Curve," a substantial portion of the field data used to develop the South Carolina live-bed contraction-scour envelope curve included scour measurements likely associated with historic flows near the 100-year flow magnitude; therefore, the envelope curves can be used to assess scour potential for such flow conditions (Benedict and Caldwell, 2009). (Note: The live-bed contraction-scour envelope curves should not be considered a definitive estimate of the contraction-scour depth associated with the 100-year flow.) However, the South Carolina live-bed contractionscour envelope curve was not recommended for assessing scour potential for extreme floods such as the 500-year flow (Benedict and Caldwell, 2009). In order to gain insights on the relative increase in contraction-scour depth associated with the 100- to 500-year flows, a theoretical adjustment coefficient similar to that developed for pier scour (see report section "Relative Increase in Theoretical Pier Scour Associated With the 100- to 500-Year Flows") can be developed for live-bed contraction scour. Although such adjustments do not provide a definitive estimate of the 500-year contraction-scour depth, they do provide perspective on the relative increase. A summary of the compiled theoretical live-bed contractionscour data and the analysis of the 500-year flow adjustment coefficient are presented below.

\section{Theoretical Live-Bed Contraction-Scour Data}

The South Carolina Theoretical Bridge Scour Database (http://dx.doi.org/10.3133/sir20165121), as previously described in the report section "Theoretical Pier-Scour Data," includes 99 theoretical live-bed contraction-scour depths for both the 100- and 500-year flows that were used to evaluate the 500-year flow adjustment coefficient. In addition to the South Carolina data, the Missouri level-2 data (Huizinga and Rydlund, 2004) included theoretical computations for 103 live-bed contraction-scour estimates and were used as a means to confirm the trends of the South Carolina data. The Missouri data are available at http://pubs.usgs.gov/ sir/2004/5213/. 


\section{The 500-Year Flow Adjustment Coefficient}

The relation of the theoretical live-bed contraction scour for the 100- and 500-year flows for the South Carolina and Missouri data is shown in figure 54, including trend lines through each dataset. Summary statistics for the data are provided in table 20. The scatter about the trend line for the South Carolina data is small, and the coefficient of determination is high (0.97) indicating that there is a strong correlation in the data. The trend line through the Missouri data falls in close proximity to the South Carolina trend line indicating that South Carolina trend line is reasonable. The equation for the South Carolina trend line is as follows:

$$
\text { Scour }_{500}=1.32 \text { Scour }_{100}
$$

where

$$
\begin{aligned}
& \text { Scour }_{500} \begin{array}{c}
\text { is the 500-year flow theoretical scour } \\
\text { depth, in feet; and }
\end{array} \\
& \text { Scour }_{100} \text { is the 100-year flow theoretical scour } \\
& \text { depth, in feet. }
\end{aligned}
$$

Equation 27 can be divided by $S_{\text {cour }}{ }_{100}$ and simplified to the following form:

$$
K_{500}=1.32,
$$

where $K_{500}$ is the theoretical 500-year flow adjustment coefficient that represents the ratio of the 500-year flow to 100 -year flow theoretical live-bed contraction-scour depths, and other variables are as previously defined. The $K_{500}$ coefficient can be applied to the South Carolina live-bed contraction-scour envelope curves (figs. 48, 49, 53) to increase the contractionscour depth by the relative increase in theoretical live-bed contraction scour associated with the 100- to 500-year flow condition. The $K_{500}$ is a helpful tool for gaining perspective on the relative increase of theoretical scour associated with the 100- to 500-year pier-scour depth. However, the adjusted envelope curve values should not be considered a definitive estimate of the contraction scour associated with the 500-year flow.

Table 20. Descriptive statistics for the ratio of the 500- and 100-

\begin{tabular}{|c|c|c|c|c|}
\hline \multirow[b]{2}{*}{$\begin{array}{c}\text { Descriptive } \\
\text { statistic }\end{array}$} & \multicolumn{2}{|c|}{ South Carolina ( $N=99)$} & \multicolumn{2}{|c|}{ Missouri ( $N=103$ ) } \\
\hline & $\begin{array}{l}\text { Ratio of } 0.500 \\
\text { and } 0100 \\
\text { theoretical } \\
\text { contraction- } \\
\text { scour depths }\end{array}$ & $\begin{array}{c}\text { Drainage } \\
\text { area } \\
\left(\mathrm{mi}^{2}\right)\end{array}$ & $\begin{array}{l}\text { Ratio of } 0500 \\
\text { and } 0100 \\
\text { theoretical } \\
\text { contraction- } \\
\text { scour depths }\end{array}$ & $\begin{array}{c}\text { Drainage } \\
\text { area } \\
\left(\mathbf{m i}^{2}\right)\end{array}$ \\
\hline Minimum & 1.00 & 0.91 & 1.00 & 3.64 \\
\hline 25 th percentile & 1.28 & 10.6 & 1.46 & 12 \\
\hline Mean & 1.94 & 230 & 2.62 & 121 \\
\hline Median & 1.43 & 26.3 & 1.75 & 25.7 \\
\hline 75th percentile & 1.68 & 60.8 & 2.30 & 101 \\
\hline Maximum & 12.5 & 8,312 & 19.50 & 1,790 \\
\hline
\end{tabular}
year flow, theoretical live-bed contraction-scour depths used in the regression analysis for selected theoretical data from South Carolina and Missouri.

[N, number of measurements; Q500, 500-year flow; Q100, 100-year flow; $\mathrm{mi}^{2}$, square mile]

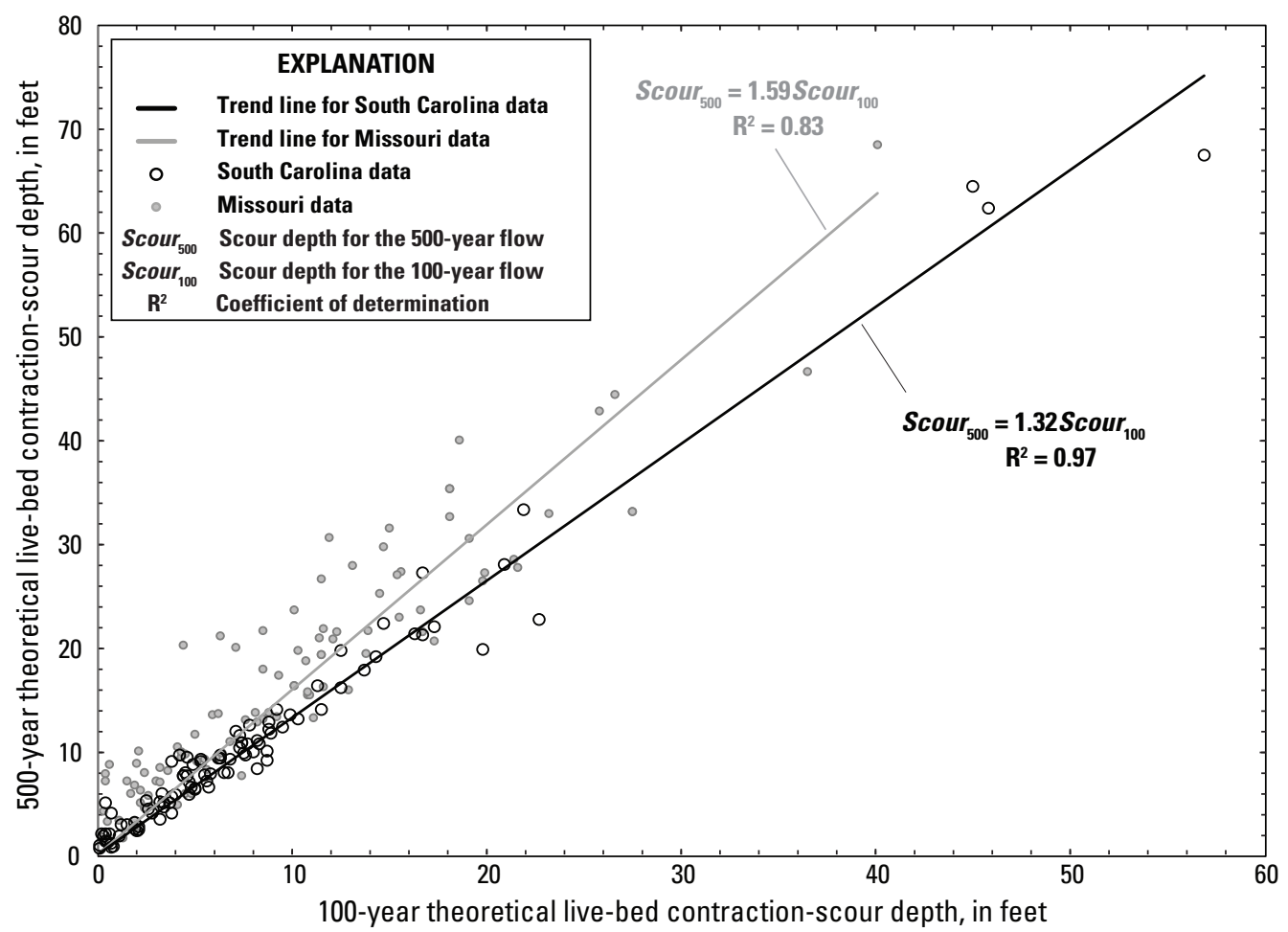

Figure 54. Relation of the 100and 500-year flow, theoretical live-bed contraction-scour depths for selected data from level-2 bridge-scour studies in South Carolina and Missouri. 


\section{Application and Limitations of the South Carolina Live-Bed Contraction- Scour Envelope Curves}

Benedict and Caldwell (2009, 2012) noted that substantial uncertainty can be associated with assessing the potential for live-bed contraction scour in South Carolina, making judgment a critical component in evaluating this component of scour. Although the South Carolina live-bed contraction-scour envelope curves (figs. 48B, 49A, 53) can be useful supplementary tools for assessing live-bed contraction-scour at bridges in South Carolina, the difficulty in evaluating this scour component should be considered carefully. Application of the live-bed contraction-scour envelope curves should be limited to sites having similar characteristics to those of sites used to develop the curves. Because the envelope curves were developed from a limited sample of bridges in the Coastal Plain and Piedmont of South Carolina, scour depths could exceed those determined from the envelope curves. The envelope curves are not intended for tidally influenced sites that may be encountered in the Coastal Plain. Additionally, the potential error and uncertainty associated with the live-bed contractionscour measurements also is a source of uncertainty in the estimates from the envelope curves. Applying a safety factor to the envelope curve estimates would be considered prudent. Because the envelope curves were derived from measured data, with many of the sites having historic flows close to the 100-year flow magnitude, the determination of hydraulic variables should be based on flows near this magnitude. The envelope curves should not be used to evaluate live-bed contraction-scour depths for extreme conditions, such as the 500 -year flow. To gain insights on the relative change in the theoretical live-bed contraction-scour depth associated with the 100- to 500-year flow, the 500-year coefficient (eq. 28) may be applied to the envelope curve estimates.

When applying the live-bed contraction-scour envelope curves, one must select a reference surface, estimate the drainage area and geometric-contraction ratio, select the appropriate contraction-scour envelope curve, evaluate other scour components in the contraction-scour region, and consider the limitations associated with the envelope curves. The following guidance may provide some assistance in applying the modified envelope curves.

\section{Select a reference surface:}

The reference surface should be the average thalweg elevation along the profile of the channel in the live-bed contractionscour region at the bridge. The thalweg is defined as the low point of the channel bed and should represent the natural conditions unaffected by scour. This reference surface can be determined by plotting the thalweg elevation at selected cross sections along the channel profile and then placing a best-fit line through those data to determine a reference surface. In many cases, defining the average thalweg elevation should not be a difficult task; however, the channel-bed topography at selected sites can be complex, making the determination of a reference surface more difficult. In such cases, judgment should be applied, bearing in mind that lower referencesurface elevations will produce lower scour-hole elevations and more conservative scour assessments. For additional details, refer to Benedict and Caldwell (2009).

\section{Estimate the drainage area and geometric- contraction ratio:}

The original and modified envelope curves can be sensitive to the selection of drainage area and the geometriccontraction ratio; therefore, it is important that accurate estimates of these variables be obtained. The drainage area for a given site can be determined by using standard computer software for determining topographic features. The geometric-contraction ratio can be determined by using flow models, topographic maps, and road plans, and when possible, all three sources should be used for verification. When discrepancies exist between these sources, judgment should be used to determine the most reasonable estimate of the geometric-contraction ratio.

The geometric-contraction ratio was evaluated with the WSPRO flow model (Shearman, 1990; Arneson and Shearman, 1998) for the 100-year flow condition. To estimate the geometric-contraction ratio, the WSPRO model uses a standard location of the approach cross section at one bridge length upstream from the bridge, which represents the full, natural flood plain width with no adjustment for ineffective flow areas. (Note: The bridge hydraulics algorithm and associated cross sections in the HEC-RAS model [Brunner, 2016] differ from that of the WSPRO model, and when using the HEC-RAS model to estimate the geometric-contraction ratio, judgment must be used to assure that the estimates are comparable to those used in Benedict [2003], which were based on the WSPRO model. Guidance regarding this matter is presented in the report section "Guidance for Applying the South Carolina Bridge-Scour Envelope Curves.”)

\section{Select the appropriate live-bed contraction-scour envelope curve:}

Live-bed contraction-scour depth can be assessed by using the original envelope curves (figs. $48 B, 49 A$ ) or the modified envelope curve (fig. 53). To utilize the modified envelope curves, the drainage area must be $200 \mathrm{mi}^{2}$ or less, and the geometric-contraction ratio should not exceed 0.90 . Additionally, the site characteristics of the bridge of interest should fall within the range of the appropriate South Carolina regional data used to develop the modified envelop curves (table 18). If these criteria are not met, then the original livebed contraction-scour envelope curves must be used following the application guidance from Benedict and Caldwell (2009). Because of the uncertainty of assessing live-bed contraction scour, interpolation between the modified envelope curves for live-bed contraction scour is not recommended. 


\section{Evaluate the pier scour within the contraction- scour region:}

Because of the complexity associated with pier and contraction scour in a river channel, Benedict and Caldwell (2009) concluded that it was uncertain if the original live-bed contraction-scour envelope curves (figs. 48B, 49A) would account for pier scour. Therefore, judgment must be used to account for potential pier scour in addition to the component of live-bed contraction scour when using the original or modified live-bed contraction-scour envelope curves. For additional guidance, refer to Benedict and Caldwell (2009).

\section{Consider the limitations of the live-bed contraction- scour envelope curves:}

The modified South Carolina live-bed contraction-scour envelope curves can be useful supplementary tools for assessing live-bed contraction-scour potential at bridges in South Carolina; however, the following limitations of these empirical envelope curves should be considered.

- The live-bed contraction-scour envelope curves were developed from a limited sample of bridges in the Piedmont and Coastal Plain of South Carolina, and it is possible that scour depths could exceed the envelope curves. Therefore, applying a safety factor to the modified envelope curves may be prudent.

- Application of the live-bed contraction-scour envelope curves should be limited to bridges having site characteristics similar to those used to develop the envelope curves.

- The South Carolina live-bed contraction-scour envelope curves were developed using field data from sites with flows approaching the 100-year flow and, therefore, should not be used to evaluate live-bed contraction-scour depths for extreme conditions, such as the 500-year flow. To gain insights on the relative change in the theoretical live-bed contraction-scour depth associated with the 100-year to 500-year flow, the 500-year scour coefficient (eq. 28) may be applied to the envelope curve.

- The live-bed contraction-scour envelope curves do not account for adverse field conditions, such as channel bends, natural channel constrictions, channel migration, dune bedforms, and debris, which may increase scour depths.

Although the South Carolina live-bed contraction-scour envelope curves presented in this report can serve as a valuable supplementary tool in assessing live-bed contractionscour depths in South Carolina, the potential errors and limitations restrict their use. Therefore, the envelope curves should not be relied upon as the only tool for assessing live-bed contraction scour. To best assess anticipated scour, one should compile and study the available information for a given site and then bring sound engineering principles and judgment to bear on the final estimate of live-bed contraction-scour depth.

\section{Guidance for Using the South Carolina Bridge-Scour Envelope Curves and Databases}

The South Carolina bridge-scour envelope curves and the large databases used in their development can serve as valuable supplementary tools for assessing bridge scour in South Carolina. The three databases compiled in the previous investigations (Benedict, 2003; Benedict and Caldwell, 2006, 2009) can be used for site comparisons to gain understanding of historical scour depths at particular sites having similar characteristics to a site of interest. In contrast to site comparisons, the South Carolina bridge-scour envelope curves provide a broader illustration of the upper-bound patterns of scour based on a large sample of bridges in South Carolina, with a limited measure of verification based on field data from sources outside of South Carolina. The South Carolina envelope curves can be used in several ways, including (1) evaluation of predicted scour from laboratory equations by comparing them with the envelope curves, and (2) evaluation of the upperbound of scour potential at a given site as represented in the envelope curves. This section of the report provides guidance for using the South Carolina bridge-scour envelope curves and databases to assess scour potential in South Carolina.

\section{Using the Bridge-Scour Databases for Site Comparisons}

The South Carolina bridge-scour databases published with their associated reports (Benedict, 2003; Benedict and Caldwell, 2006, 2009) provide a valuable resource for understanding historical scour depths in South Carolina. Links for downloading these three databases are provided in table 21. (Note: The Internet address for the PSDb-2014 pier scour database [Benedict and Caldwell, 2014] also is provided in table 21.) These three databases include photographs, some figures, measured scour depths, predicted scour depths, limited basin characteristics, limited soil data, and selected hydraulic data determined from one-dimensional flow models and can be viewed using Microsoft $\AA$ Access $\AA$. The databases provide automated report formats that can be used to view data for a given site. The raw data also can be viewed in tabular format. In addition to the bridge-scour databases, appendix 2 identifies historical peak flows that have occurred at selected bridge sites in the South Carolina studies, providing insights into the flow conditions that likely created the measured historical scour. Arneson and others (2012) recommend that predicted scour obtained from laboratory-prediction equations be evaluated for reasonableness by comparing it with available historical data at or near the site of interest, and the South Carolina databases provide a useful tool to assist with such comparisons. Furthermore, the review of historical scour at sites near a site of interest help the practitioner develop judgment with regard to ranges for anticipated scour under differing field conditions. 
Various approaches can be used to compare sites, including the use of figure 1 and appendix 1 to identify and select sites near a site of interest, or querying the databases to identify and select sites having similar characteristics to the site of interest. Or perhaps it may be appropriate to retrieve selected field data from a given county, or neighboring counties, where a site of interest is located. Table 22 provides an example of selected scour data retrieved from the South Carolina databases for bridges located in Spartanburg County, South Carolina. The data example in table 22 indicates relatively moderate values of the geometric-contraction ratio (all but one are 0.6 or less), relatively small embankment lengths (most are less than $200 \mathrm{ft}$ ), and all scour depths, except one, are less than $5 \mathrm{ft}$, with the largest scour depth of $7.8 \mathrm{ft}$ being associated with the largest geometric-contraction ratio of 0.7 . It also is noteworthy that most of these sites have historical flow data from the 1995 flood when flows exceeded the 100-year flow magnitude, indicating that the measured scour reflects scour associated with a large flow event. Other information for the sites listed in table 22, such as hydraulic model data, predicted scour, soil data, and photographs, can be retrieved from the databases. Comparing such data with the characteristics for a site of interest can assist in further promoting understanding of scour potential. Additionally, review of topographic maps, aerial photographs, road and bridge plans, bridge inspection reports, and soil borings can yield insights regarding the potential for scour at the selected comparison sites and the site of interest. (Note: The South Carolina databases include latitude and longitude for each site that can be used to locate the site on topographic maps and aerial photography.) Compiling and reviewing the above noted information for a group of comparison sites helps identify scour patterns and field characteristics associated with such patterns. Assuming that a site of interest in or near Spartanburg County has characteristics similar to the bridges listed in table 22 , it would be reasonable to expect similar scour patterns.

Although site comparisons, as described above, is not the only tool for assessing scour potential at sites in South Carolina, it is a valuable tool when used in conjunction with the South Carolina bridge-scour envelope curves and the prevailing scour-prediction technology (currently HEC-18; Arneson and others, 2012).

Table 21. Internet addresses for the South Carolina bridge-scour databases.

\begin{tabular}{lccc}
\multicolumn{1}{c}{ Database } & Scour components & Source & Internet address \\
\hline $\begin{array}{l}\text { The South Carolina Bridge } \\
\text { Scour Database (SCBSD) }\end{array}$ & $\begin{array}{c}\text { Clear-water abutment } \\
\text { scour }\end{array}$ & Benedict (2003) & http://pubs.usgs.gov/wri/wri034064/ \\
$\begin{array}{l}\text { The South Carolina Clear-Water } \\
\text { Pier- and Contraction-Scour }\end{array}$ & $\begin{array}{c}\text { Clear-water overbank } \\
\text { contraction and }\end{array}$ & Benedict and Caldwell (2006) & https://doi.org/10.3133/sir20055289 \\
Database (SCPCSD) & pier scour & & http://pubs.usgs.gov/sir/2009/5099/ \\
The South Carolina Live-Bed & Live-bed channel & Benedict and Caldwell (2009) & \\
Pier- and Contraction-Scour & contraction and & & http://pubs.usgs.gov/ds/0845/ \\
Database (SCLBSD) & pier scour & & \\
2014 USGS Pier-Scour & Clear-water and live- & Benedict and Caldwell (2014) & \\
Database (PSDb-2014) & bed pier scour & & \\
\hline
\end{tabular}

Table 22. Example of comparison scour data obtained from the South Carolina bridge-scour databases for sites in Spartanburg County, South Carolina.

[SCDOT, South Carolina Department of Transportation; mi², square mile; ft, foot; S.C., South Carolina Route; S, secondary road; U.S., United States Route; -, missing data]

\begin{tabular}{|c|c|c|c|c|c|c|c|c|c|}
\hline Road & Stream & $\begin{array}{c}\text { SCDOT } \\
\text { structure } \\
\text { number }\end{array}$ & $\begin{array}{c}\text { Drainage } \\
\text { area at } \\
\text { bridge } \\
\left(\mathrm{mi}^{2}\right)\end{array}$ & $\begin{array}{l}\text { Bridge } \\
\text { length } \\
\text { (ft) }\end{array}$ & $\begin{array}{l}\text { Calendar } \\
\text { year for } \\
\text { maximum } \\
\text { historic flow } \\
\text { at bridge }\end{array}$ & $\begin{array}{c}\text { Ratio of } \\
\text { maximum } \\
\text { historic flow } \\
\text { to 100-year } \\
\text { flow at } \\
\text { bridge }\end{array}$ & $\begin{array}{l}\text { Geometric } \\
\text { contraction } \\
\text { ratio for } \\
\text { abutment } \\
\text { scour }\end{array}$ & $\begin{array}{l}\text { Left } \\
\text { embankment } \\
\text { length } \\
\text { (ft) }\end{array}$ & $\begin{array}{l}\text { Left } \\
\text { abutment } \\
\text { scour } \\
\text { depth } \\
\text { (ft) }\end{array}$ \\
\hline U.S. 29 & South Tyger River & 422002900100 & 76 & 270 & 1995 & 1.1 & 0.5 & 63 & 0 \\
\hline U.S. 221 & South Tyger River & 422022110300 & 137 & 250 & 1995 & 1.35 & - & - & - \\
\hline S.C. 146 & Enoree River & 424014600100 & 127 & 292 & - & - & 0.5 & 187 & 0 \\
\hline S.C. 296 & Enoree River & 424029600100 & 119 & 250 & - & - & 0.5 & 63 & 0.7 \\
\hline S.C. 417 & South Tyger River & 424041700200 & 113 & 240 & 1995 & 1.18 & - & - & - \\
\hline S-62 & South Tyger River & 427006200500 & 91.8 & 270 & 1995 & 1.82 & 0.4 & 114 & 0 \\
\hline S-118 & Enoree River & 427011800001 & 186 & 370 & 1995 & 4.65 & 0.6 & - & - \\
\hline S-242 & South Tyger River & 427024200200 & 94.4 & 200 & 1995 & 1.09 & 0.02 & 43 & 0.6 \\
\hline
\end{tabular}




\section{Guidance for Applying the South Carolina Bridge-Scour Envelope Curves}

The South Carolina bridge-scour envelope curves represent the upper-bound patterns of scour based on a large sample of field data collected in South Carolina. The comparison of the South Carolina envelope curves with field data from other sources, as described previously in this report, provides some measure of verification that the envelope curves are reasonable. As such, the envelope curves offer a valuable resource for understanding the upper-bound trends of scour and can be used as supplementary tools for assessing scour potential at bridges in South Carolina. This report section provides guidance for applying the South Carolina bridge-scour envelope curves to assess scour potential at sites in South Carolina. The guidance is presented in an outline form that gives application steps. Additionally, examples for applying the envelope curves are given at the end of this report section. A bridge opening generally has two regions of scour (figs. 4, 5): (1) clear-water scour on the bridge overbank, and (2) live-bed scour in the main channel. The application of the South Carolina bridgescour envelope curves has unique considerations for these regions and, therefore, application guidance is described separately for these regions. In all cases and all steps when evaluating scour using the envelope curves, engineering judgment should be used to evaluate the reasonableness and application of the results.

\section{Assessing Clear-Water Scour in the Bridge Overbank}

There are two primary regions of scour on bridge overbanks including the abutment-scour region and contraction-scour region (fig. 23). As noted in the report section "The South Carolina Clear-Water Contraction-Scour Envelope Curve," clear-water abutment-scour depths can be substantially larger than clear-water contraction-scour depths. Therefore, it is important to differentiate these types of scour and the general regions of the overbank where they are most likely to occur. When assessing scour on the bridge overbank, clear-water abutment scour should be evaluated first followed by an evaluation of clear-water contraction scour. The evaluation of abutment scour generally includes (1) the assessment of the upper bound of abutment scour using the appropriate abutment-scour envelope curve (figs. 26, 27, 30, $31,33$, or 34$)$, (2) the assessment of clear-water pier scour in the abutment-scour region, if required (fig. 7 or 18), and (3) an assessment of the extent, or top width, of the abutmentscour hole on the overbank. The remaining overbank area is assumed to be the region of contraction scour (fig. 23). The evaluation of clear-water contraction-scour includes (1) the assessment of the upper bound of clear-water contraction scour using the clear-water contraction-scour envelope curve (fig. 43), and (2) the assessment of clear-water pier scour in the contraction-scour region, if required (fig. 7 or 18). If the assessed scour depth in the clear-water contraction-scour region (fig. 23) exceeds that of the assessed scour depth in the abutment-scour region (fig. 23), then the scour depth in the clear-water contraction-scour region should be assumed to represent the best estimate of scour for the abutment and applied to the abutment-scour region as well. The general application steps are outlined below. For additional details, reference can be made to the report sections, "Application and Limitations of the South Carolina Abutment-Scour Envelope Curves" and "Application and Limitations of the Clear-Water Contraction-Scour Envelope Curve."

Table 22. Example of comparison scour data obtained from the South Carolina bridge-scour databases for sites in Spartanburg County, South Carolina.-Continued

[SCDOT, South Carolina Department of Transportation; mi², square mile; ft, foot; S.C., South Carolina Route; S, secondary road; U.S., United States Route; -, missing data]

\begin{tabular}{|c|c|c|c|c|c|c|c|c|c|}
\hline $\begin{array}{l}\text { Right } \\
\text { embankment } \\
\text { length } \\
\text { (ft) }\end{array}$ & $\begin{array}{c}\text { Right } \\
\text { abutment } \\
\text { scour depth } \\
\text { (ft) }\end{array}$ & $\begin{array}{l}\text { Left overbank } \\
\text { clear-water } \\
\text { contraction } \\
\text { scour depth } \\
\text { (ft) }\end{array}$ & $\begin{array}{l}\text { Right overbank } \\
\text { clear-water } \\
\text { contraction } \\
\text { scour depth } \\
\text { (ft) }\end{array}$ & $\begin{array}{l}\text { Clear-water } \\
\text { pier width } \\
\text { (ft) }\end{array}$ & $\begin{array}{l}\text { Clear-water } \\
\text { pier scour } \\
\text { depth } \\
\text { (ft) }\end{array}$ & $\begin{array}{l}\text { Live-bed } \\
\text { pier width } \\
\text { (ft) }\end{array}$ & $\begin{array}{l}\text { Live-bed } \\
\text { pier scour } \\
\text { depth } \\
\text { (ft) }\end{array}$ & $\begin{array}{l}\text { Geometric } \\
\text { contraction } \\
\text { ratio for live- } \\
\text { bed contrac- } \\
\text { tion scour }\end{array}$ & $\begin{array}{l}\text { Live-bed } \\
\text { contraction } \\
\text { scour } \\
\text { (ft) }\end{array}$ \\
\hline 216 & 0.4 & 0 & 0 & 0.9 & 0.8 & 1.6 & 4.6 & 0.5 & 0 \\
\hline 121 & 1.1 & - & - & - & - & - & - & - & - \\
\hline- & - & - & - & - & - & - & - & 0.7 & 7.8 \\
\hline 37 & 0 & 0.9 & - & 1.5 & 0.7 & 1.5 & 3.5 & 0.5 & 3 \\
\hline 234 & 3.1 & - & 1.3 & 0.8 & 1.6 & - & - & - & - \\
\hline
\end{tabular}




\section{Assessing Clear-Water Abutment-Scour Potential}

1. Select the reference surface.

- The reference surface should be selected on the basis of the natural flood plain elevation and not an existing scour hole. Use field surveys and bridge/road plans to determine the average flood plain elevation in the abutment-scour region (fig. 23).

2. Estimate abutment geometric variables.

- The envelope curves can be sensitive to the selection of the embankment length $(L)$ and the geometriccontraction ratio $(m)$. Therefore, it is important to obtain accurate estimates of these variables. In general, $L$ and $m$ should be determined conservatively and should be based on (1) flow conditions near the 100 -year flow, and (2) the full flood plain width (left edge of water to right edge of water) for the natural, unconstricted approach cross section with no adjustment for ineffective flow areas associated with the bridge contraction. Additionally, unusual approach flow conditions, such as levees or skewed abutments, that may tend to narrow the width of the approaching flow should generally be neglected to assure conservative estimates of $L$ and $m$. Use hydraulic models to determine $L$ for left and right abutments (edge of water to abutment toe; fig. 28) and $m$ (fig. 29) and check topographic maps and road plans.

- In the original investigation (Benedict, 2003) the WSPRO model (Shearman, 1990; Arneson and Shearman, 1998) was used to estimate these variables. The bridge hydraulics algorithm in the WSPRO model assumes that the contraction of flow into a bridge begins at a cross section located one bridge-length upstream from the bridge, called the approach cross section. The WSPRO approach cross section represents the natural upstream cross section with no effects from the bridge contraction or adjustments for ineffective flow areas. The WSPRO model calculates the value of $m$ for the bridge using the general approach shown in figure 29. The values of $L$ were determined by projecting the bridge section onto the approach section as shown in figure 28. In determining $L$ and $m$, it is important to understand the cross-section configuration used in the WSPRO model and reference should be made to Arneson and Shearman (1998) for additional details. The bridge hydraulics algorithm in the HEC-RAS model (Brunner, 2016) differs from that of the WSPRO model in that the cross sections upstream from the bridge are adjusted to account for ineffective flow areas associated with the bridge contraction. The adjusted approach cross sections in the HEC-RAS model should not be used to determine $L$ and $m$. Instead, a natural, unadjusted cross section approximately one bridge length upstream from the bridge should be used. If substantial variation of the flood plain width in the river reach extends approximately one bridge length upstream from the bridge, judgment must be used to select a natural, unconstricted approach cross section that will provide a conservative but reasonable estimate of $L$ and $m$. In some cases, it may be prudent to go further upstream beyond the one bridge width to assure conservative estimates of these variables. In many cases, the flood plain and channel in the approaching reach upstream from the bridge is relatively uniform, and in such cases, it may be appropriate to use the natural, unconstricted cross section near the bridge to evaluate $L$ and $m$. Because field conditions can present unique site characteristics that deviate from the ideal estimate, application of engineering judgment is critical to assure that conservative yet reasonable estimates of $L$ and $m$ are obtained.

- In the case of a multiple-bridge opening, the WSPRO model estimates the portion of the unconstricted approach cross section that contributes flow to each bridge and subdivides the approach cross section accordingly into slices. The geometriccontraction ratio is determined for each bridge by using the associated slice section rather than the entire approach cross section. (In figure 29, the slice section would be substituted for the full approach cross section.) Each bridge opening can be projected onto the corresponding slice section to determine the left and right embankment lengths. (In figure 28, the slice section would be substituted for the full approach cross section.) The multiple-bridge opening hydraulics algorithm in the HEC-RAS model (Brunner, 2016) is similar, but not identical, to the algorithm in the WSPRO model. Therefore, when using the HEC-RAS model to evaluate $L$ and $m$ at a multiple-bridge opening, caution and engineering judgment must be used to assure that conservative yet reasonable estimates of $L$ and $m$ are obtained. Reference should be made to Arneson and Shearman (1998) and Brunner (2016) for additional details regarding the hydraulics of multiple-bridge openings for the WSPRO and HEC-RAS models, respectively.

- Old bridge and road plans often provide a survey of the original ground line at the centerline of the road that gives a reasonable representation of the natural unconstricted cross section at a bridge. This cross section, in conjunction with an approximation of the water-surface elevation, can be used to estimate $L$ and $m$. Similarly, the edge of the unconstricted flood plain is often a distinct feature on a topographic map. This feature, in conjunction with the bridge location on the map, can be used to estimate $L$ and $m$. 
- When discrepancies exist between $L$ and $m$, as determined by hydraulic models, topographic maps, and road plans, evaluate why these discrepancies exist and use judgment in the final selection of these variables.

- The clear-water abutment-scour potential should be estimated for both the left and right abutments separately unless the site meets the criteria for Special Cases 1 and 2 described later in this report section.

3. Select the appropriate envelope curves based on the regional location of the site (Piedmont or Coastal Plain).

- Embankment-length envelope curves.

- Piedmont (fig. 26; table 7; eq. 13): $L \leq 950 \mathrm{ft}$.

- Coastal Plain (fig. 27; table 7; eq. 14): $L \leq 7,440 \mathrm{ft}$; because there are few data with $L>2,000 \mathrm{ft}$, caution should be used for $L>2,000 \mathrm{ft}$.

- Geometric-contraction ratio envelope curve (figs. 30 or 31; table 7; eqs. 16 and 17).

- Piedmont (fig. 30; table 7; eq. 16): $m \leq 0.82$.

- Coastal Plain (fig. 31; table 7; eq. 17): $m \leq 0.98$; because there are few data with $L>2,000 \mathrm{ft}$, caution should be used for $L>2,000 \mathrm{ft}$.

- Modified envelope curve.

- Piedmont (fig. 33; table 8; table 9 for equations): $L \leq 500 \mathrm{ft}$; see table 9 for limits of $m$.

- Coastal Plain (fig. 34; table 8; table 9 for equations): $L \leq 500 \mathrm{ft}$; see table 9 for limits of $m$.

- Evaluate if site characteristics are within the range of the data for the envelope curve by comparing with noted tables above.

- If yes, proceed; if no, use of the specific envelope curve becomes questionable.

- Uncertainty of the envelope curve increases near the limits of the data range.

4. Apply the selected curves and evaluate the results.

- To avoid overestimates of the range for abutment-scour depth, it may be reasonable to use the embankmentlength envelope curve as the primary tool for estimating abutment-scour depth in the Piedmont and Coastal Plain of South Carolina (Benedict, 2003). However, judgment should be used in selecting the final estimate of abutment scour based on the specific characteristics for the site of interest.

- If a conservative estimate of the range of abutmentscour depth is needed, then the larger scour depth obtained from the geometric-contraction ratio or embankment-length envelope curve may be more appropriate (Benedict, 2003). If the top width of the potential abutment-scour hole, as determined from figure 42, extends to the channel, use the largest scour depth from the clear-water abutment-scour and contraction-scour estimates.

- Special Case 1: Single-bridge opening crossing swamp with a poorly defined channel having a bridge length of approximately $240 \mathrm{ft}$ or less (see report section "Single-Bridge Openings)

- Assume a large, single scour hole develops across the entire bridge opening.

- Use the longest $L$ from the left and right abutments along with geometric-contraction ratio and apply to the selected envelope curves to assess abutmentscour potential.

- Use judgment in selecting the final estimate of abutment scour based on the specific characteristics of the site being assessed.

- If a conservative estimate of the range of abutmentscour depth is needed, then the larger scour depth obtained from the geometric-contraction ratio or embankment-length envelope curves may be more appropriate (Benedict, 2003).

- If values between the various envelope curves differ substantially, assess why and consider use of the larger value if deemed appropriate.

- Special Case 2: Multiple-bridge opening (see report section "Multiple-Bridge Openings)

- Piedmont sites:

- Use only the $m$ envelope curve.

- Coastal Plain sites:

- For $L<426 \mathrm{ft}$, use only the $m$ envelope curve.

- For $L \geq 426 \mathrm{ft}$, evaluate with $m$ and $L$ envelope curves; generally use the smallest value unless a more conservative estimate is considered more reasonable; if values differ substantially, assess why and consider use of the larger value if deemed appropriate. If the bridge of interest is a flood plain relief bridge with a poorly defined channel having a bridge length of approximately $240 \mathrm{ft}$ or less (similar to Special Case 1), use the longest $L$ from the left and right abutments along with the geometric-contraction ratio and apply to the selected Coastal Plain envelope curves to assess abutment-scour potential.

- Use judgment in selecting the final estimate of abutment scour based on the specific characteristics of the site being assessed.

- If a conservative estimate of the range of abutment-scour depth is needed, then the larger scour depth obtained from the geometric-contraction ratio or embankment-length envelope curves may be more appropriate (Benedict, 2003). 
- If values between the various envelope curves differ substantially, assess why and consider use of the larger value if deemed appropriate.

5. No adjustment is required for contraction scour in the abutment-scour region.

6. Adjust for pier scour in the abutment region.

- If pier width $\leq 2.3 \mathrm{ft}$ and skew is minimal, do not add pier-scour depth.

- For larger piers or piers with large skews, add pierscour depth.

- Use guidance for assessing pier scour as described later in this report section.

- Special Case in Piedmont: If abutment-scour depth $\leq 5 \mathrm{ft}$, add pier scour regardless of pier width; for abutment-scour depth $>5 \mathrm{ft}$, follow the above-noted guidance for adjusting for pier scour.

7. Evaluate site characteristics that may adversely affect abutment scour and factor into final assessment of scour potential, including but not limited to the following:

- Adverse effects from debris.

- Field conditions that may create unusual flow distributions that direct flow into the abutment-scour region during high flows and thus may increase scour depths. Such conditions may include natural channel constrictions, channel migration, dune bedforms, and debris.

8. Apply the 500-year flow adjustment coefficients to the selected values of abutment and pier scour.

- Pier-scour adjustment (eq. 12).

- Abutment-scour adjustment (eq. 19).

- This adjustment provides perspective on the relative increase in theoretical abutment and pier scour associated with the 100- to 500-year flow condition.

9. Use abutment-scour-hole top-width envelope curves to evaluate the extent of abutment scour on the overbank (fig. 42).

- The lateral reference point for applying the estimated top width of the abutment-scour hole should be the abutment toe; the remaining overbank area beyond the abutment-scour-hole top width is considered the region of clear-water contraction scour (fig. 23).

\section{Assessing Clear-Water Contraction-Scour Potential}

1. Select the reference surface.

- The reference surface should be selected on the basis of the natural flood plain elevation and not an existing scour hole. Use field surveys and bridge/road plans to determine the average flood plain elevation in the contraction-scour region (fig. 23).

2. Estimate the geometric-contraction ratio.

- Follow the guidance in the report section "Assessing Clear-Water Abutment-Scour Potential” for evaluating this variable.

3. Apply the clear-water contraction-scour envelope curve (fig. 43; table 13; eq. 20): $m \leq 0.95$.

- The envelope curve is applicable to both the Piedmont and Coastal Plain.

- Evaluate if site characteristics are within the range of the data for the envelope curve by comparing the characteristics with noted tables above.

- If yes, proceed; if no, use of the envelope curve becomes questionable.

- Uncertainty of the envelope curve increases near the limits of the data range. In particular, use caution when applying the curve between $m$ values of 0.90 and 0.95 .

4. Adjust for pier scour in the contraction-scour region.

- Pier-scour depth as determined from the South Carolina clear-water or PSDb-2014 pier-scour envelope curves should be added to the assessment of clear-water contraction-scour potential.

- Use guidance for assessing pier scour as described later in this report section.

5. Evaluate site characteristics that may adversely affect contraction scour and factor into the final assessment of scour potential, including but not limited to the following:

- Adverse effects from debris.

- Field conditions that may create unusual flow distributions, such as channel bends, which may direct flow into the contraction-scour region during high flows, thus increasing the potential for scour.

6. Apply the 500-year flow adjustment coefficients to the selected values of clear-water contraction and pier scour.

- Pier-scour adjustment (eq. 12).

- Clear-water contraction-scour adjustment (eq. 22).

- This adjustment provides perspective on the relative increase in theoretical clear-water contraction and pier scour associated with the 100 - to 500-year flow condition.

7. Determine the extent of clear-water contraction-scour on the overbank. If abutment scour encompasses the entire overbank, then no contraction scour is applied to the overbank. 


\section{Assessing Live-Bed Contraction-Scour Potential}

Benedict and Caldwell (2009) did not identify a definitive method for qualitatively assessing the potential for live-bed contraction scour and noted that there is a substantial measure of uncertainty associated with assessing the potential for live-bed contraction scour in South Carolina. Therefore, using judgment and caution is critical when making such assessments. This should be kept in mind when assessing live-bed scour potential with the South Carolina live-bed contractionscour envelope curves.

1. Select the reference surface.

- The reference surface should be selected on the basis of the natural average thalweg elevation and not an existing scour hole. Use field surveys and bridge/ road plans to determine the average thalweg elevation (channel low point) in the main channel at the bridge.

2. Estimate the geometric-contraction ratio.

- Follow the guidance in the report section "Assessing Clear-Water Abutment-Scour Potential" for evaluating this variable.

3. Apply the live-bed contraction-scour envelope curves.

- Dimensionless envelope curve (for comparison purposes).

- Piedmont curve (fig. $48 B$; table 16; eq. 25): $m \leq 0.85$.

- Coastal Plain curve (fig. 48B; table 16; eq. 24): $m \leq 0.87$.

- Theoretical curve for conservative assessment (fig. 48B; eq. 23): limits of $m$ are undefined.

- Field envelope curve.

- Piedmont and Coastal Plain (fig. 49A; table 16; eq. 26): $m \leq 0.82$.

- The clear-water contraction-scour data used for comparison with the live-bed contraction-scour envelope curve (fig. 49B) suggest it may be appropriate to extend the envelope curve beyond a geometric-contraction ratio of 0.82 ; however, the differing nature of the clear-water contraction- and live-bed contraction-scour data makes it difficult to make a strong conclusion.

- Modified envelope curve (for drainage areas $\leq 200 \mathrm{mi}^{2}$ ).

- Piedmont and Coastal Plain (fig. 53; table 18; table 19 for equations): $m \leq 0.9$.

- Evaluate if site characteristics are within the range of the data for the envelope curve by comparing the characteristics with noted tables above.

- If yes, proceed; if no, use of the envelope curve becomes questionable.
- Uncertainty of the envelope curve increases near the limits of the data range.

4. Adjust for pier scour in contraction-scour region.

- Pier-scour depth as determined from the South Carolina live-bed or PSDb-2014 pier-scour envelope curves should be added to the assessment of live-bed contraction-scour potential.

- Use guidance for assessing pier scour as described later in this report section.

5. Evaluate site characteristics that may adversely affect live-bed contraction and pier scour and factor into the final assessment of scour potential, including but not limited to the following:

- Adverse effects from debris.

- Field conditions that may create unusual flow distributions that direct flow into the contraction-scour region during high flows and thus may increase scour depths. Such conditions may include natural channel constrictions, channel migration, dune bedforms, and debris.

6. Apply the 500-year flow adjustment coefficients to the selected values of live-bed contraction and pier scour.

- Pier-scour adjustment (eq. 12).

- Live-bed contraction-scour adjustment (eq. 28).

- This adjustment provides perspective on the relative increase in theoretical live-bed contraction and pier scour associated with the 100- to 500-year flow condition.

7. Because the channel bed and thalweg can shift during high-flow events, it is assumed that the live-bed contraction scour will extend across the entire main channel. In addition, for piers in the overbank area, the possibility of channel widening and (or) shifting occurring over time might also need to be considered.

\section{Assessing Pier-Scour Potential}

1. Estimate the nominal pier width $(b)$.

- The pier-scour envelope curves do not account for unusual or complex pier geometries or for exposed footings, and so judgment must be used to assess the applicability of the pier-scour envelope curves for these types of piers.

2. Select appropriate pier-scour envelope curve.

- Clear-water pier scour on overbank (fig. 7; table 1; eq. 2): $b \leq 6 \mathrm{ft}$.

- Live-bed pier scour in main channel (fig. 10; table 2; eq. 6 ): $b \leq 6 \mathrm{ft}$. 
- PSDb-2014 pier scour (fig. 14; table 4; eq. 9): $6 \mathrm{ft}<b \leq 15 \mathrm{ft}$.

- Evaluate if site characteristics are within the range of the data for the envelope curve by comparing with noted tables above.

- If yes, proceed; if no, use of the envelope curve becomes questionable.

- Uncertainty of the envelope curve increases near the limits of the data range.

3. Because the channel bed and thalweg can shift during high-flow events, it is assumed that the live-bed contraction scour will extend across the entire main channel. In addition for piers in the overbank area, the possibility of channel widening and (or) shifting occurring over time might also need to be considered.

4. Account for pier skew.

- Pile bents

- For pile bents with skews approximately 15 degrees or less and spacings between piles of approximately 5 pile widths, no adjustment for skew is required; if adverse field conditions exist or are anticipated at the site, use of equation 4 following the guidance as recommended in HEC-18 (Arneson and others, 2012) may be appropriate.

- For pile bents with skews exceeding approximately 15 degrees or with spacings between piles smaller than 5 pile widths, adjust for skew using equation 4 following the guidance as recommended in HEC-18 (Arneson and others, 2012).

- Piers

- Adjust for skew using equation 4 following the guidance as recommended in HEC-18 (Arneson and others, 2012).

5. Evaluate site characteristics that may adversely impact pier scour and factor into the final assessment of scour potential, including, but not limited to the following:

- Adverse effects from debris.

- Channel bends that may create a larger potential for scour.

- Channel widening and shifting (for piers near the channel banks).

6. Apply the 500-year flow adjustment coefficients to the selected values of pier scour.

- Pier-scour adjustment (eq. 12).

- This adjustment provides perspective on the relative increase in theoretical pier scour associated with the 100- to 500 -year flow condition.

\section{Limitations of the South Carolina Bridge-Scour Envelope Curves}

1. The envelope curves are empirical.

- The envelope curves are empirical methods that are based on limited field samples; it is possible that scour could exceed the envelope curves; therefore, application of a safety factor may be prudent.

- Application of the envelope curves is constrained to the range of data and site characteristics used to develop the envelope curves.

- The uncertainty associated with the envelope curves increases near the limits of the data range.

- The live-bed scour data have the largest uncertainty.

2. The envelope curves do not account for unusual site conditions such as:

- Debris

- Channel bank failures

- Pressure flow

- Unusual flow patterns created by unique site conditions

- Unusual pier geometries

- Washout of approach road embankments

3. The field data generally represent scour associated with flows approaching the 100-year flow magnitude but should not be interpreted as representing the " 100 -year" scour estimate. Additionally, the envelope curves should not be used to evaluate scour potential for larger flows, such as the 500-year flow. The 500-year flow adjustment coefficients can be used to provide perspective on the relative increase in theoretical scour associated with the 100- to 500-year flow condition but should not be interpreted as providing a "500-year" scour estimate.

4. Subsurface soils can impede or promote scour. Therefore, assessing the potential effect of subsurface soils on scour is important.

\section{Example Problems}

The following example problems are provided as a general overview of a few of the types of assessments that could be made using the South Carolina bridge-scour envelope curves. The examples should not be viewed as being all inclusive with respect to the steps that might need to be taken for an actual bridge-scour assessment. For such assessments, the reader should closely follow the steps listed in the "Guidance for Applying the South Carolina Bridge-Scour Envelope Curves" section and other sections in this document providing greater details for such analyses. The information needed to apply the South Carolina bridge-scour envelope curves should be obtained using all available sources and based on engineering 
judgment. The reader is once again reminded that the curves represent empirical methods that have a number of limitations as previously discussed. The South Carolina bridge-scour envelope curves are useful tools for assessing potential for scour at riverine bridges in South Carolina; however, the envelope curves should not be relied upon as the only tool for assessing bridge scour but rather should be used in conjunction with the prevailing scour-prediction technology (currently HEC-18). To best assess potential scour, one should compile and study the available information for a given site, evaluate scour with the South Carolina bridge-scour envelope curves and the prevailing scour-prediction technology (currently HEC-18), and then bring sound engineering principles to bear on the final estimate of potential abutment-scour depth. Each bridge site will likely have unique characteristics requiring that sound engineering judgment be applied for a thorough assessment of the various potential scour components. (Note: Potential scour estimates for these examples have been rounded to two significant digits.)

\section{Example 1: Coosawhatchie River at Road S-87 in Jasper County}

The site for example 1 is located in the Coastal Plain of South Carolina. Figure 55 shows the bridge-site data for this example, and figure 56 shows the approach section information. The flood plain reference surface was determined to be $19.5 \mathrm{ft}$ (fig. 55).

\section{Clear-Water Abutment-Scour Potential}

Drainage area $(D A)=383 \mathrm{mi}^{2}$

$L=1,720 \mathrm{ft}$ (for the left embankment)

$L=1,181 \mathrm{ft}$ (for the right embankment)

$b_{2}=559 \mathrm{ft}$ (flow top width in the bridge opening)

$B_{1}=3,434 \mathrm{ft}$ (flow top width at the upstream unconstricted approach cross section)

$m=1-(559 / 3434)=0.84$ (geometric-contraction ratio, eq. 15)

The above characteristics were verified to be within the range of data used to develop the envelope curves (table 7). Because the bridge is longer than $240 \mathrm{ft}$, both the left and right embankment lengths will be used to evaluate each respective abutment-scour potential. Because $L$ for both the left and right embankments is greater than $500 \mathrm{ft}$, the modified envelope curves will not be used.

Using left embankment length and equation 14 (fig. 27), $y_{s}=16 \mathrm{ft}$

Using right embankment length and equation 14 (fig. 27), $y_{s}=15 \mathrm{ft}$

Using geometric-contraction ratio and equation 17 (fig. 31), $y_{s}=15 \mathrm{ft}$

The pier widths are $1.4 \mathrm{ft}$. Because they are less than $2.3 \mathrm{ft}$ and skew is assumed minimal, the pier-scour depth will not be added to the piers in the abutment region.

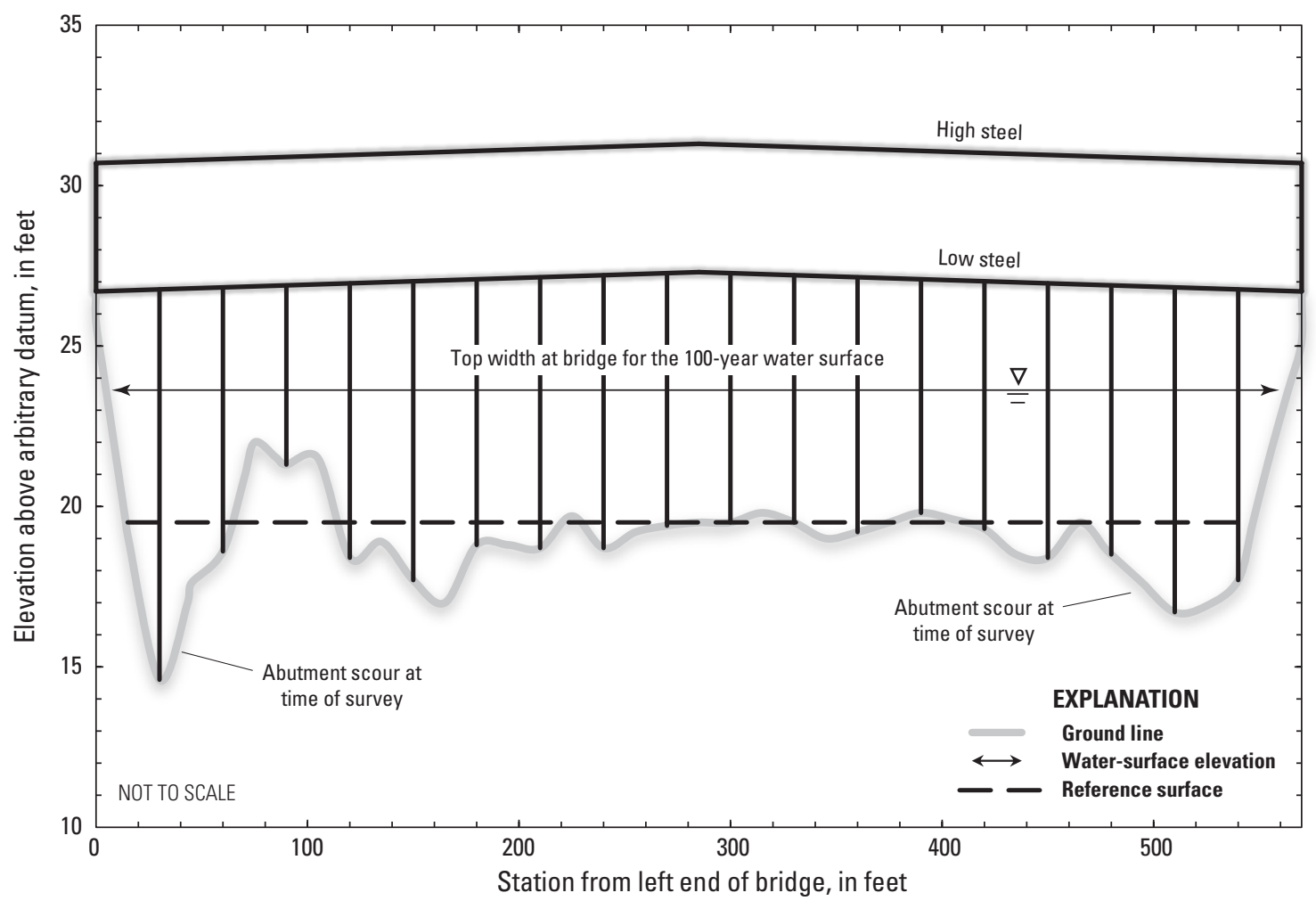

Figure 55. Bridge site information for example 1, Coosawhatchie River at Road S-87 in Jasper County, South Carolina. 


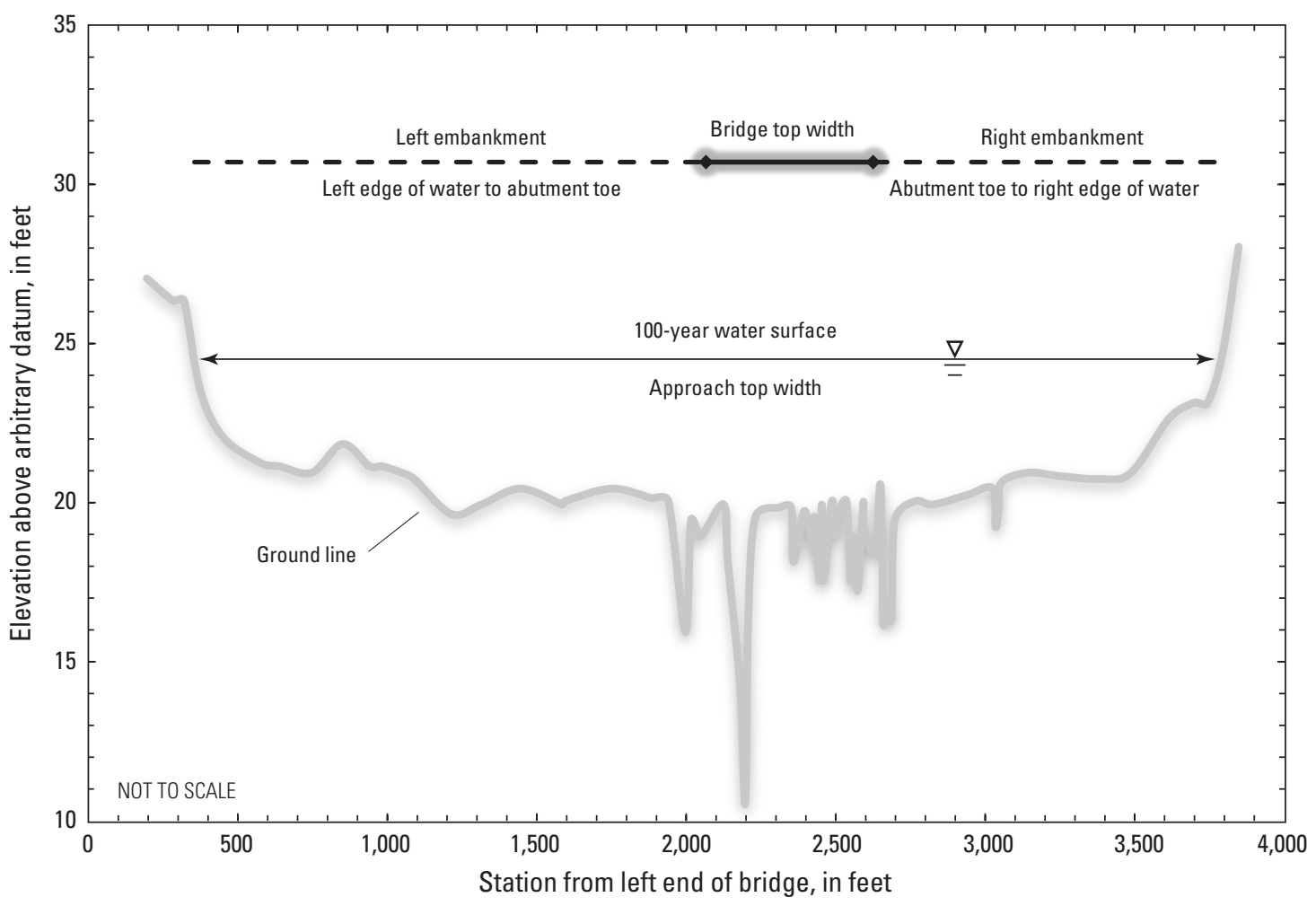

Figure 56. Approach section information for example 1, Coosawhatchie River at Road S-87 in Jasper County, South Carolina, showing bridge top width and road embankment locations projected onto the approach cross section.

\section{Abutment Scour-Hole Top Width}

To estimate the abutment scour-hole top width for the left abutment, it is assumed that a conservative estimate is desired and thus, the larger $y_{s}$ of $16 \mathrm{ft}$ from the embankmentlength envelope curve will be used instead of the estimate of $15 \mathrm{ft}$ from the geometric-contraction ratio envelope curve. Therefore, using figure $42 A$ and the $y_{s}$ of $16 \mathrm{ft}$ for the left embankment length, the left abutment scour-hole top width is estimated to be about $70 \mathrm{ft}$.

For the right abutment, the embankment-length envelope curve and the geometric-contraction ratio envelope curve provided the same estimate for $y_{s}$ of $15 \mathrm{ft}$. Using figure $42 \mathrm{~A}$, the right abutment scour-hole top width also is estimated to be about $70 \mathrm{ft}$.

\section{Clear-Water Contraction-Scour Potential}

From the geometric-contraction ratio computed previously along with equation 20 (fig. 43), the clear-water contraction-scour depth is estimated: $y_{s}=4.8 \mathrm{ft}$.

\section{Pier-Scour Potential}

Nominal pier width $=1.4 \mathrm{ft}$ with minimal skew (verified that the characteristics are within the range of the data shown in table 1). Using equation 2 (fig. 7), the clear-water pier scour depth is $2.6 \mathrm{ft}$. The total scour depth for the piers located in the clear-water overbank region, outside of the clear-water abutment-scour region, is 4.8 (previously computed clearwater contraction scour) $+2.6=7.4 \mathrm{ft}$.

The region of scour determined from these computations is shown in figure 57. It is important to remember that the scour estimates shown in figure 57 are based on hydraulic data determined from the 100-year recurrence interval flow estimated for this site in conjunction with the appropriate South Carolina bridge-scour envelope curve; and although the estimated scour depths from the envelope curves reflect scour depths associated with flows near the 100-year flow, the estimates should not be interpreted as the " 100 -year" scour estimates. In an actual analysis, the user also should utilize the available South Carolina bridge-scour databases to compare the estimated scour results with observed results from sites with similar characteristics and in similar areas of the State.

Applying the appropriate 500-year flow adjustment coefficient to the previously computed scour components results in the following (fig. 58):

\section{Clear-Water Abutment Region}

Left abutment:

Using equation 18 (fig. 41), potential clear-water abutment scour $=1.21 \times 16=19 \mathrm{ft}$.

Right abutment:

Using equation 18 (fig. 41), potential clear-water pier scour $=1.21 \times 15=18 \mathrm{ft}$. 


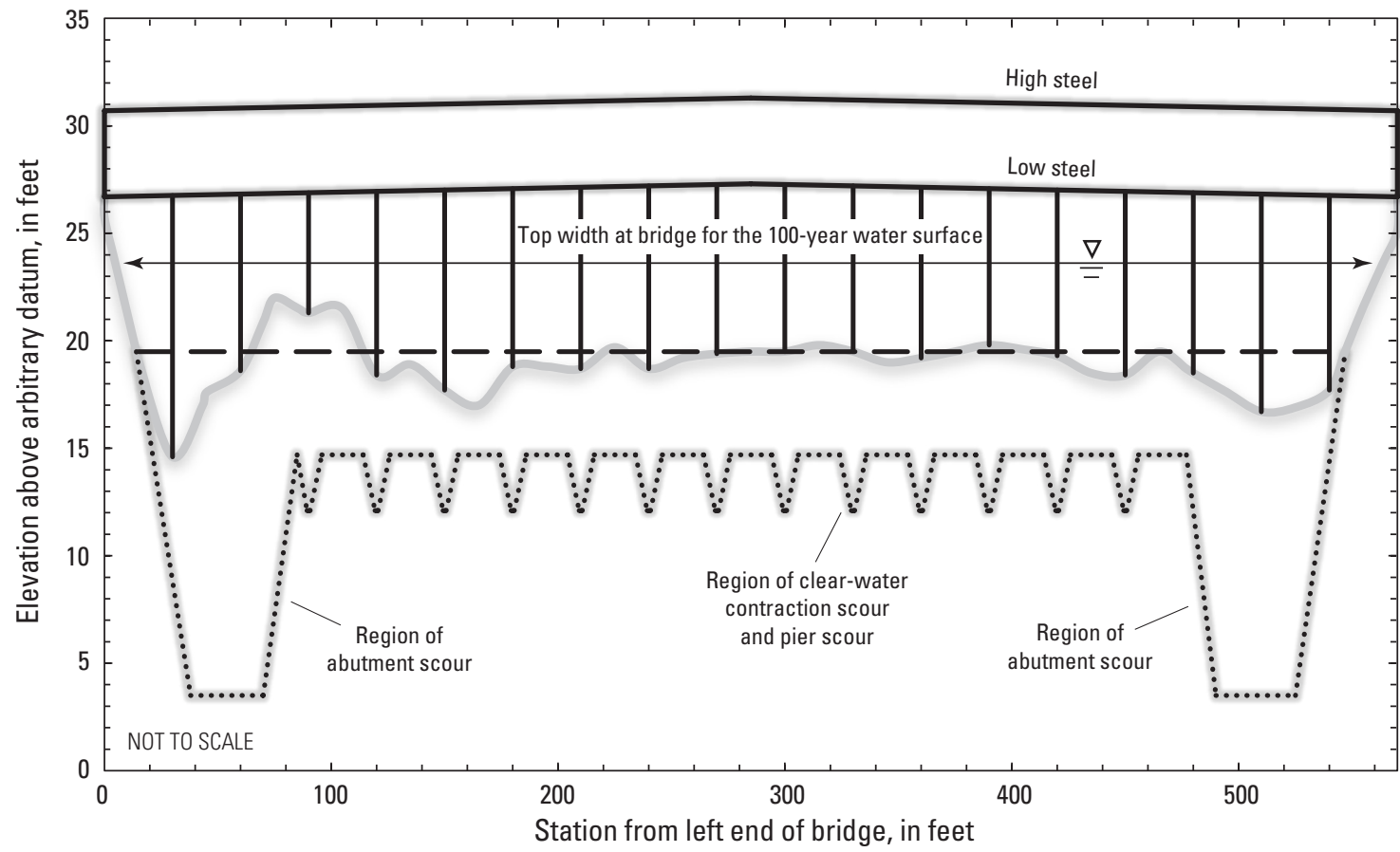

EXPLANATION

Ground line

Water-surface elevation

- - Reference surface

Scour template based on the 100-year flow

Figure 57. Region of potential scour determined from South Carolina bridge-scour envelope curves for example 1, Coosawhatchie River at Road S-87 in Jasper County, South Carolina.

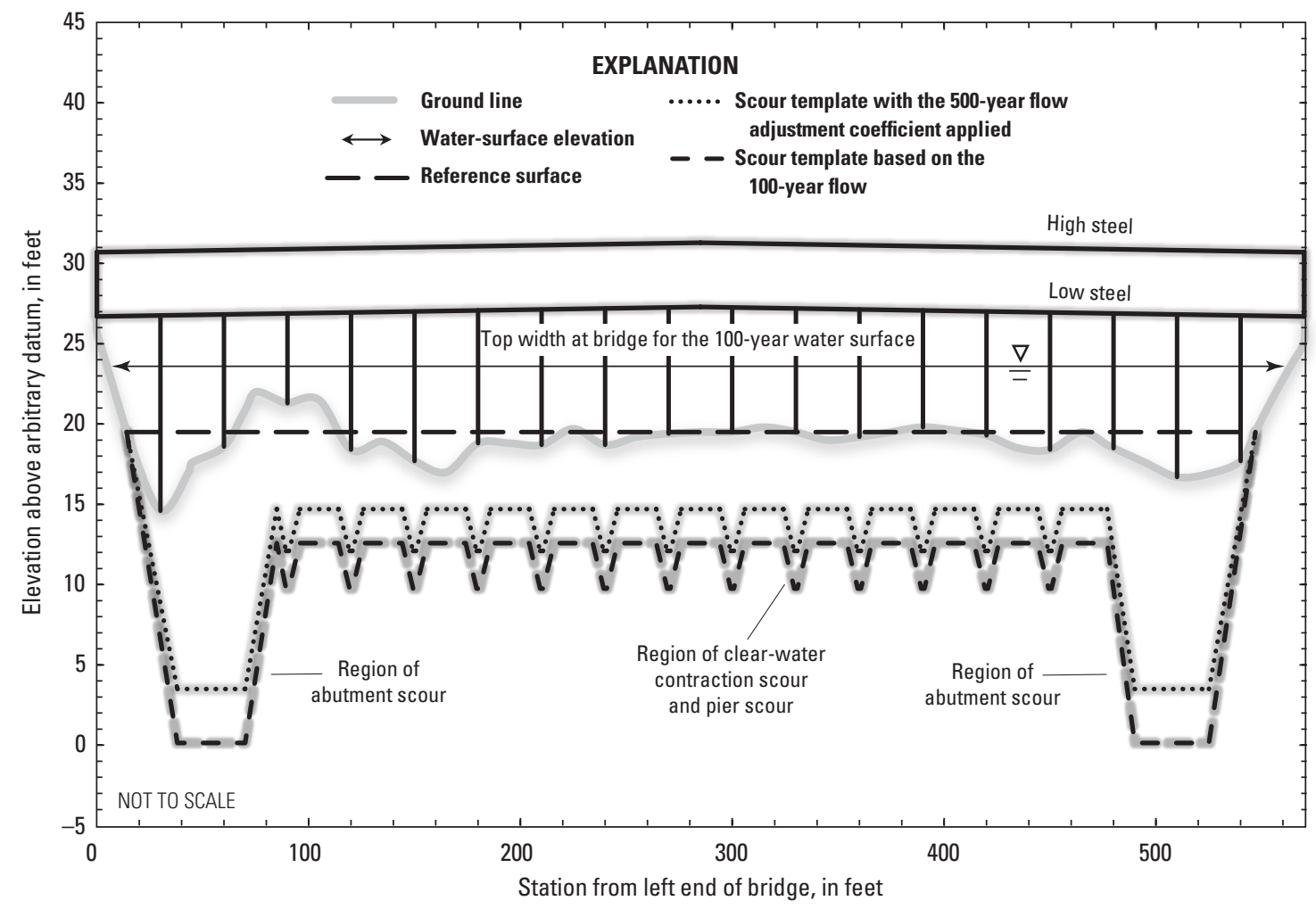

Figure 58. Region of potential scour determined from the South Carolina bridge-scour envelope curves for example 1, Coosawhatchie River at Road S-87 in Jasper County, South Carolina, with the 500-year flow adjustment coefficient applied. 


\section{Clear-Water Overbank Region}

Pier Scour:

Using equation 11 (fig. 20), potential clear-water pier scour $=1.09 \times 2.6=2.8 \mathrm{ft}$.

Contraction Scour:

Using equation 21 (fig. 46), potential clear-water contraction scour $=1.46 \times 4.8=7.0 \mathrm{ft}$.

Total potential scour at piers outside of the abutment-scour region $=2.8+7.0=9.8 \mathrm{ft}$.

Applying the 500-year flow adjustment coefficients provides perspective on the relative increase in theoretical clear-water abutment, contraction, and pier scour associated with the 100- to 500-year flow conditions but should not be interpreted as the " 500 -year" scour estimates.

\section{Example 2: Big Swamp at S.C. 51 in Florence County}

Example 2 is a swampy site located in the Coastal Plain of South Carolina. Figure 59 shows the bridge-site data for this example, and figure 60 shows the approach section information. The flood plain reference surface was determined to be $85.6 \mathrm{ft}$ (fig. 59).

\section{Clear-Water Abutment-Scour Potential}

$$
\begin{aligned}
& \mathrm{DA}=16.6 \mathrm{mi}^{2} \\
& L=552 \mathrm{ft} \text { (for the right embankment) } \\
& L=332 \mathrm{ft} \text { (for the left embankment) } \\
& b_{2}=\quad 74 \mathrm{ft} \text { (flow top width in the bridge opening) } \\
& B_{1}=944 \mathrm{ft} \text { (flow top width at the upstream unconstricted } \\
& \text { approach cross section) } \\
& m=1-(74 / 944)=0.92 \text { (geometric-contraction ratio, } \\
& \text { eq. 15) }
\end{aligned}
$$

The above characteristics were verified to be within the range of the data used to develop the envelope curves (table 7). This site is a single-bridge opening that crosses a swamp with a poorly defined channel, having a bridge length less than $240 \mathrm{ft}$. Therefore, abutment scour at this site will be assessed as Special Case 1, where a large single scour hole is assumed to form across the entire bridge opening. For this case, the longest $L$ from the left and right abutments, along with the geometric-contraction ratio, will be applied to the selected envelope curves to assess abutment-scour potential.

Using the longest embankment length (right embankment) and equation 14 (fig. 27), $y_{s}=15 \mathrm{ft}$.

Using the geometric-contraction ratio and equation 17 (fig. 31), $y_{s}=20 \mathrm{ft}$.

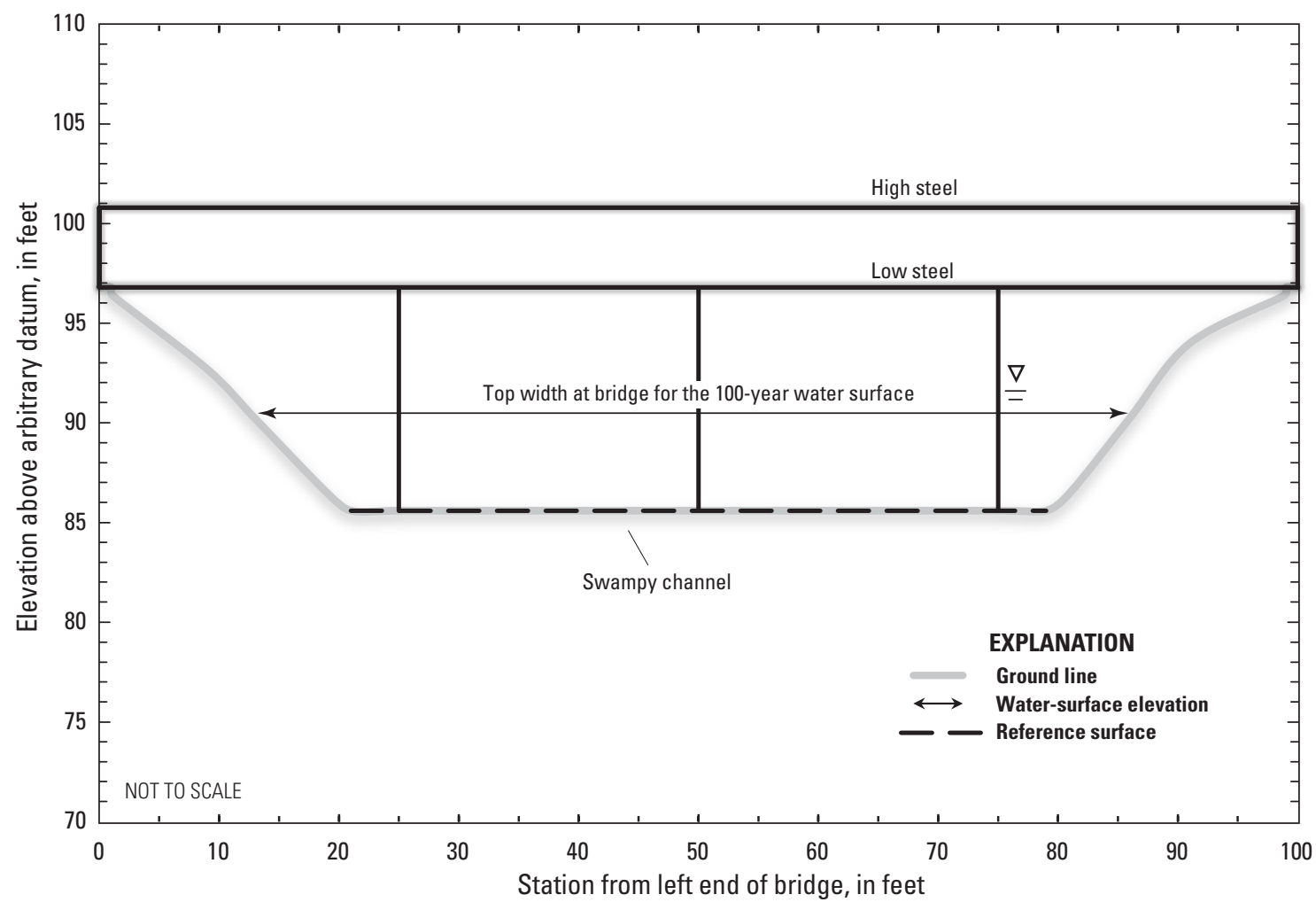

Figure 59. Bridge site information for example 2, Big Swamp at S.C. 51 in Florence County, South Carolina. 


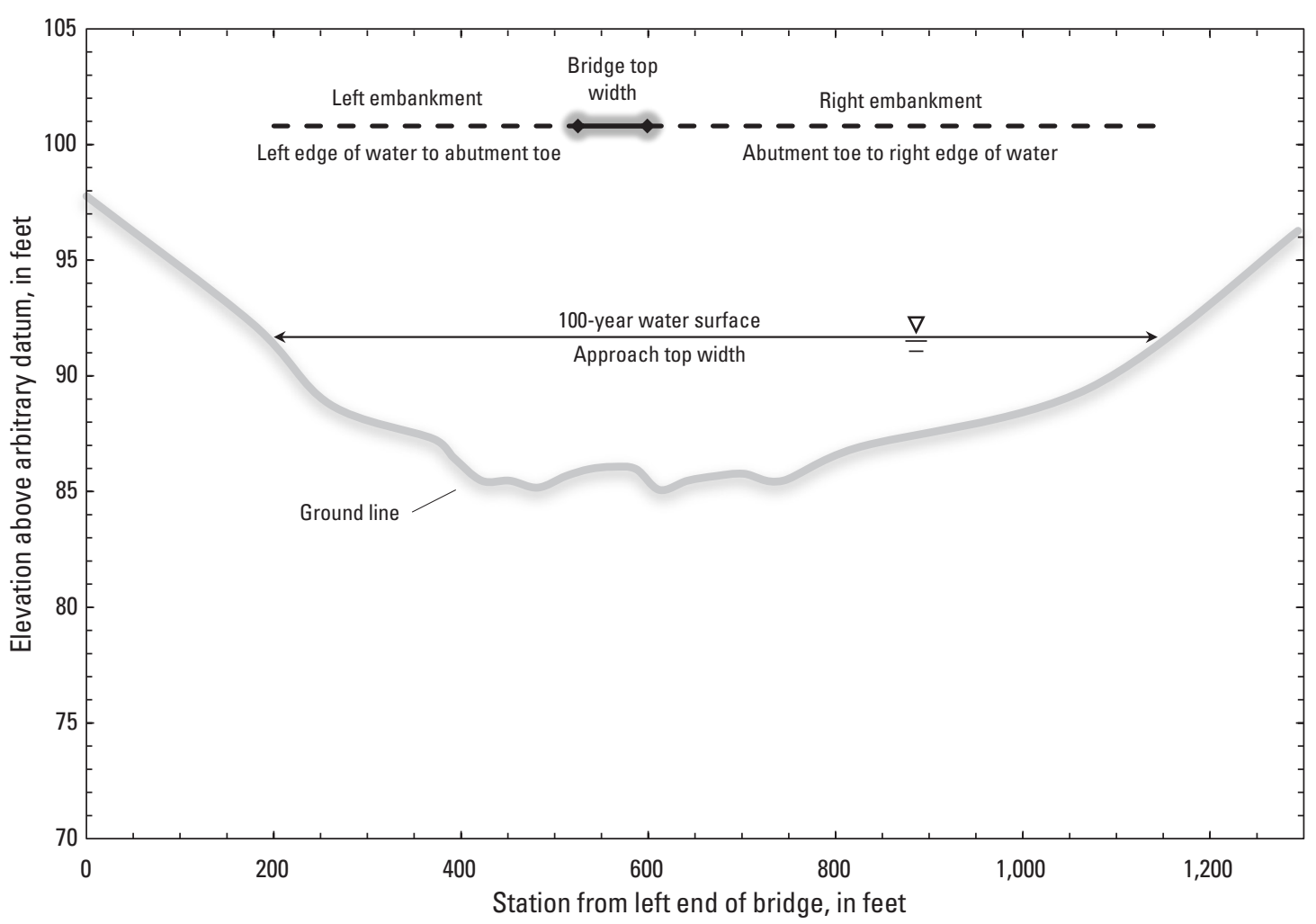

Figure 60. Approach section information for example 2, Big Swamp at S.C. 51 in Florence County, South Carolina, showing bridge top width and road embankment locations projected onto the approach cross section.

Because the longest embankment (used for Special Case 1) is greater than $500 \mathrm{ft}$, the modified envelope curves will not be used.

The pier widths are $1.0 \mathrm{ft}$. Because they are less than $2.3 \mathrm{ft}$ and skew is assumed minimal, the pier-scour depth will not be added to the piers in the abutment region.

Benedict (2003) noted that it may be reasonable to give preference to the embankment-length envelope curve rather than the geometric-contraction ratio envelope curve in order to minimize overestimates of abutment-scour depth. Additionally, this site has a relatively small drainage area $\left(16.6 \mathrm{mi}^{2}\right)$, which will tend to produce smaller abutment-scour depths (fig. 40). On the basis of these observations, the smaller scour estimate of $15 \mathrm{ft}$ was assumed to be the more reasonable value and was selected for this site.

Using figure $42 B$ and the $y_{s}$ of $15 \mathrm{ft}$ computed using the right embankment length, the abutment scour-hole top width is estimated to be about $100 \mathrm{ft}$, which exceeds the bottom width of the channel at the bridge. This pattern gives some support that the assumption of Special Case 1 is reasonable and that the abutment-scour can be assumed to encompass the bridge opening from the left abutment toe to the right abutment toe as shown in figure 61 . Because the abutment scour extends from the left abutment toe to the right abutment toe, no evaluation of clear-water contraction scour was required.
The region of scour determined from these computations is shown in figure 61. It is important to remember that the scour estimates shown in figure 61 are based on hydraulic data determined from the 100-year recurrence interval flow estimated for this site in conjunction with the appropriate South Carolina bridge-scour envelope curve; and although the estimated scour depths from the envelope curves reflect scour depths associated with flows near the 100-year flow, the estimates should not be interpreted as the " 100 -year" scour estimates. In an actual analysis, the user also should utilize the available South Carolina bridge-scour databases to compare the estimated scour results with observed results from sites with similar characteristics and in similar areas of the State.

Applying the appropriate 500-year flow adjustment coefficient to the previously computed scour components results in the following (fig. 62):

Using equation 19 , potential clear-water abutment scour $=1.21 \times 15=18 \mathrm{ft}$.

Applying the 500-year flow adjustment coefficients provides perspective on the relative increase in theoretical clear-water abutment scour associated with the 100- to 500 -year flow conditions but should not be interpreted as the "500-year" scour estimate. 


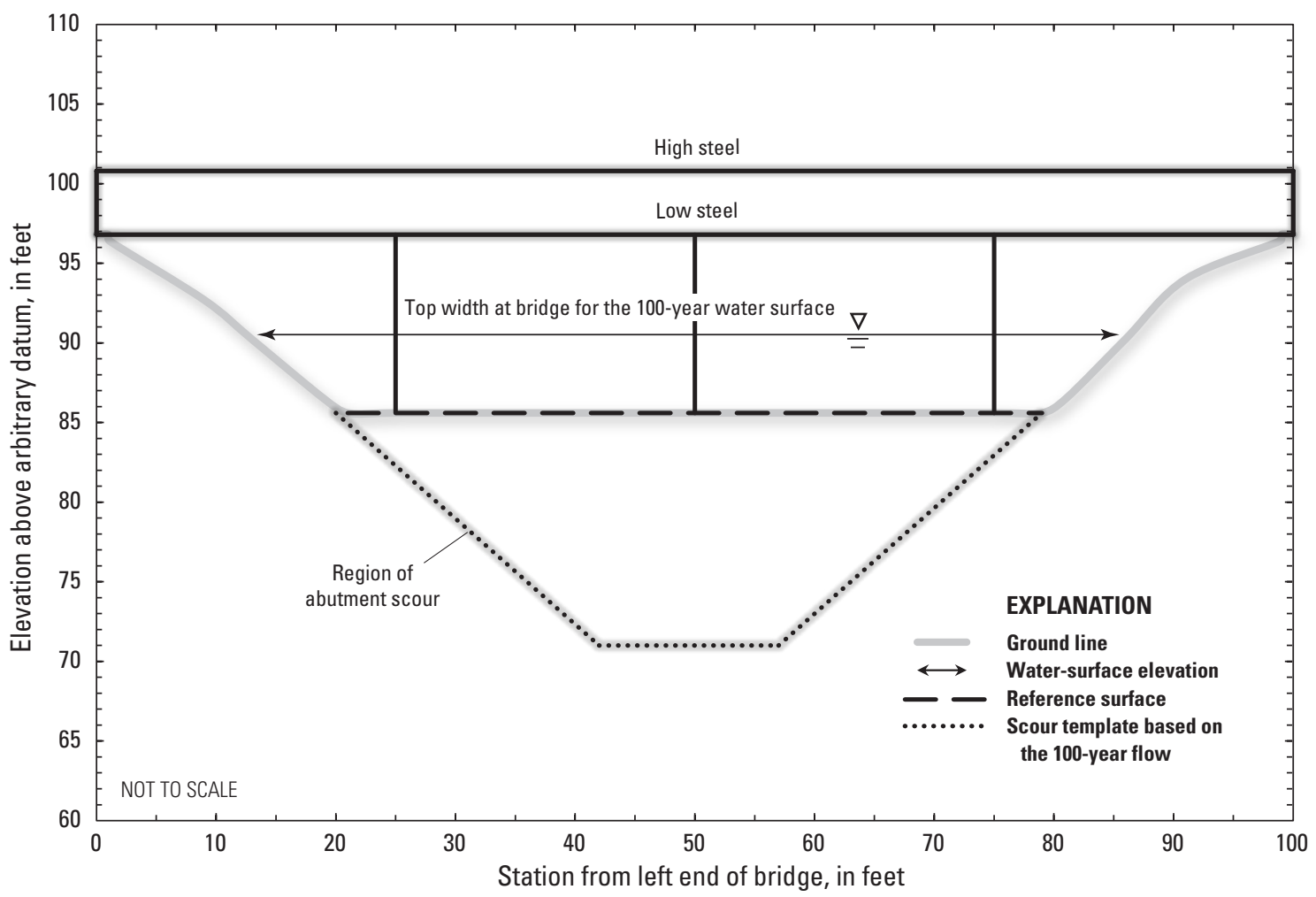

Figure 61. Region of potential scour determined from the South Carolina bridge-scour envelope curves for example 2, Big Swamp at S.C. 51 in Florence County, South Carolina.

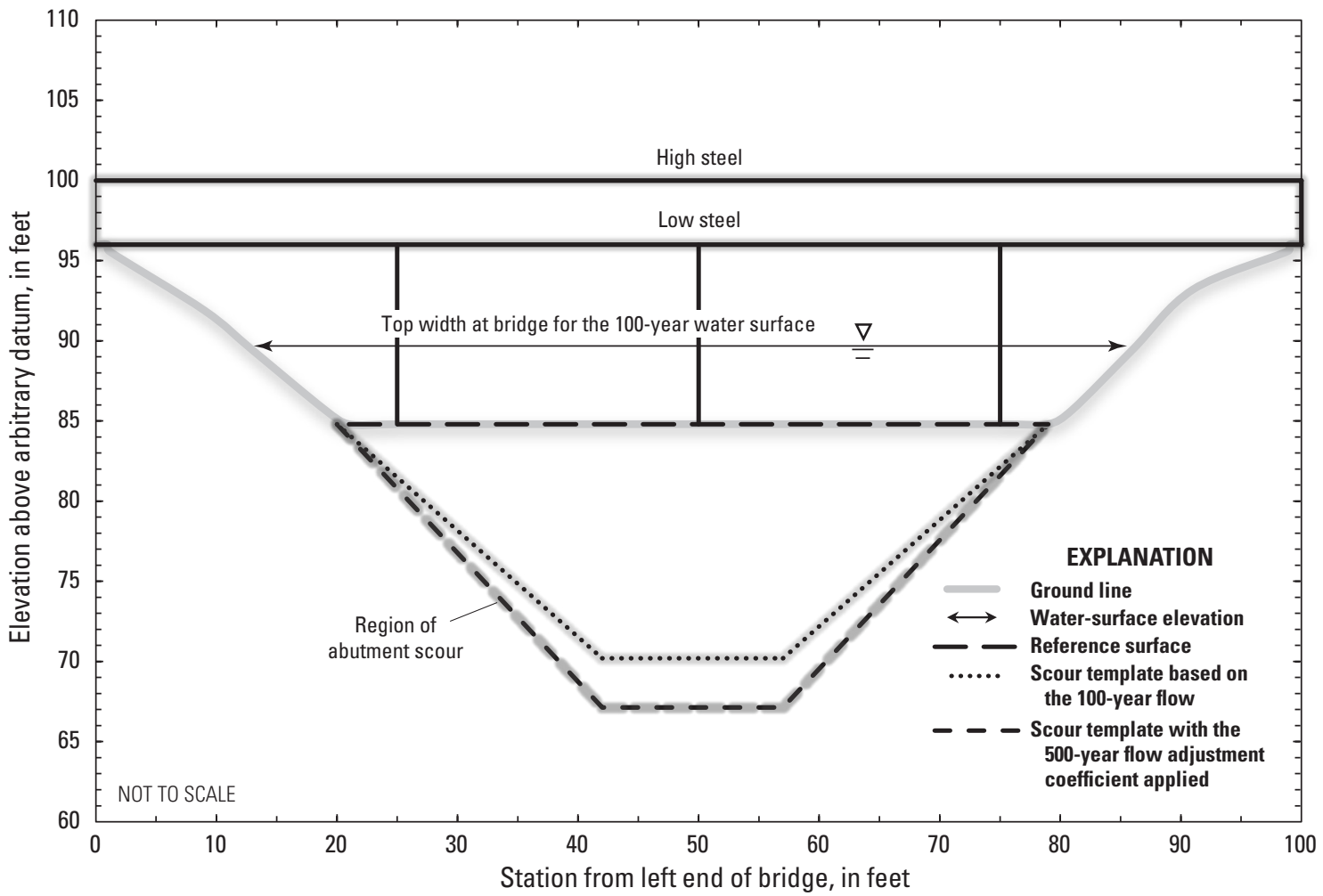

Figure 62. Region of potential scour determined from the South Carolina bridge-scour envelope curves for example 2, Big Swamp at S.C. 51 in Florence County, South Carolina, with the 500-year flow adjustment coefficient applied. 


\section{Example 3: Enoree River at Road S-87 in Newberry County}

The site for example 3 is located in the Piedmont of South Carolina. Figure 63 shows the bridge-site data for this example, and figure 64 shows the approach section information. The flood plain reference surface was determined to be $86.5 \mathrm{ft}$ (fig. 63).

\section{Clear-Water Abutment-Scour Potential}

$\mathrm{DA}=677 \mathrm{mi}^{2}$

$L=61 \mathrm{ft}$ (for the left embankment)

$L=600 \mathrm{ft}$ (for the right embankment)

$b_{2}=309 \mathrm{ft}$ (flow top width in the bridge opening)

$B_{1}=934 \mathrm{ft}$ (flow top width at the upstream unconstricted approach cross section)

$m=1-(309 / 934)=0.67$

The above characteristics were verified to be within the range of the data used to develop the envelope curves (table 7).

Using the left embankment length and equation 13

(fig. 26), $y_{s}=1.7 \mathrm{ft}$.

Using the right embankment length and equation 13

(fig. 26), $y_{s}=13 \mathrm{ft}$.

Using the geometric-contraction ratio and equation 16 (fig. 30), $y_{s}=13 \mathrm{ft}$.
Because there is a substantial variation in the length of the left and right abutments, estimating the potential abutmentscour depth using the embankment length curves instead of the geometric-contraction ratio curves is likely more reasonable for this site (Benedict, 2003). For the right abutment, the potential scour depth was the same for both curves $(13 \mathrm{ft})$, indicating that this estimate is reasonable for the right abutment. For the left embankment, however, the left abutment scour-depth estimate is $1.7 \mathrm{ft}$, much less than the $13 \mathrm{ft}$ estimated by the geometric-contraction ratio curve. The left embankment length is relatively small $(61 \mathrm{ft})$ having a scour potential much less than the right embankment with a length of $600 \mathrm{ft}$. Thus the smaller estimate of abutmentscour potential $(1.7 \mathrm{ft})$ for the left abutment appears reasonable and is selected to be the estimate of abutment scour depth (fig. 65).

The flood plain pier widths are $1.4 \mathrm{ft}$. Because they are less than $2.3 \mathrm{ft}$ and skew is assumed minimal, the potential pier-scour depth for the piers in the abutment region will not be included in the total potential scour depth.

Using figure $42 A$ and the $y_{s}$ of $13 \mathrm{ft}$, the abutment scourhole top width for the right abutment is estimated to be about $70 \mathrm{ft}$. For the left abutment using the $y_{s}$ of $1.7 \mathrm{ft}$, the left abutment scour-hole top width is estimated to be about $45 \mathrm{ft}$. Because the left abutment scour-hole width encompasses the entire overbank width, the estimated abutment-scour depth should be compared to the left clear-water overbank scour depth and the largest value used (see item 3 in report section "Assessing Clear-Water Abutment-Scour Potential").

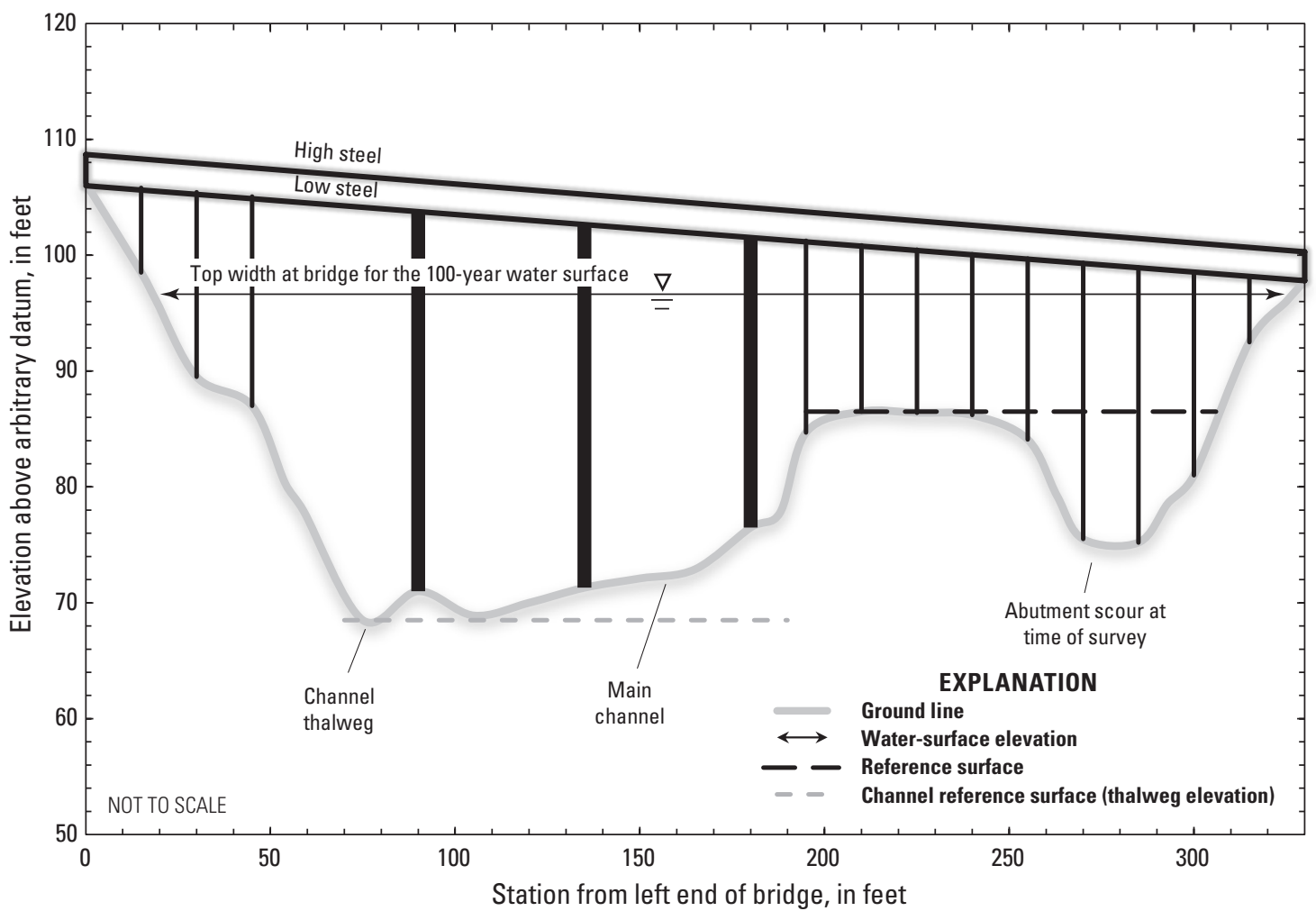

Figure 63. Bridge site information for example 3, Enoree River at Road S-87 in Newberry County, South Carolina. 


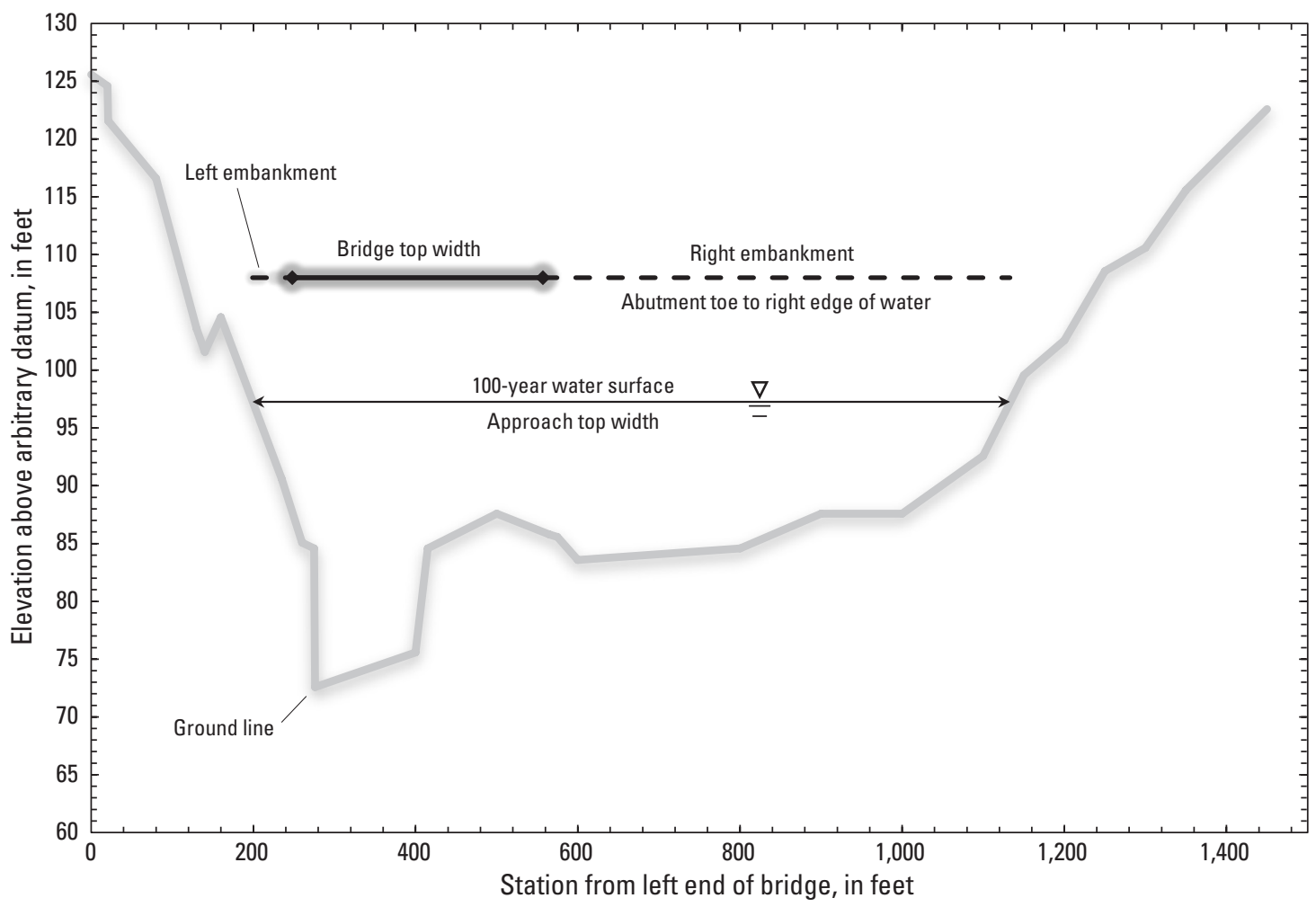

Figure 64. Approach section information for example 3, Enoree River at Road S-87 in Newberry County, South Carolina, showing bridge top width and road embankment locations projected onto the approach cross section.

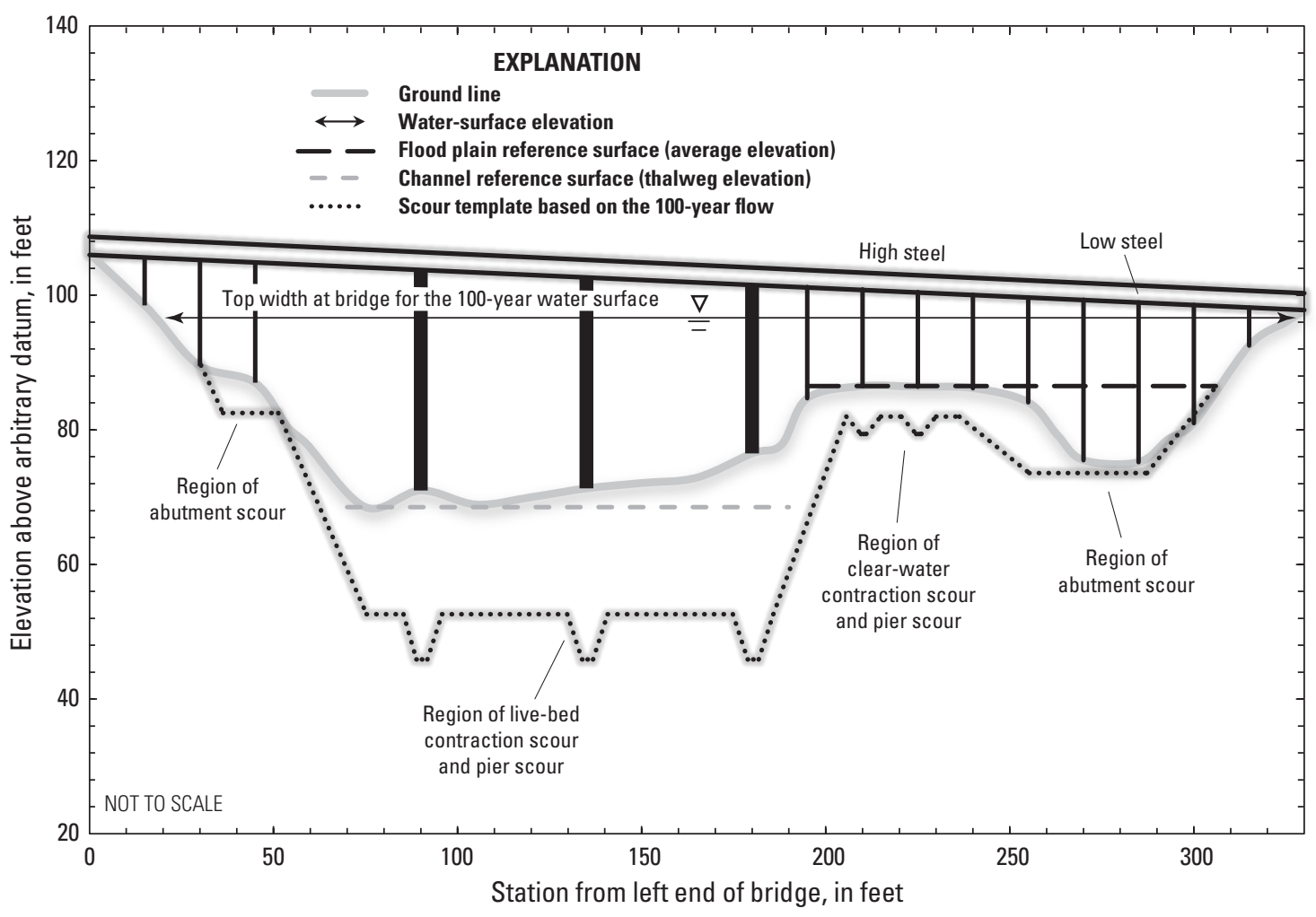

Figure 65. Region of potential scour determined from South Carolina bridge-scour envelope curves for example 3, Enoree River at Road S-87 in Newberry County, South Carolina. 


\section{Clear-Water Contraction-Scour Potential}

From the geometric-contraction ratio computed previously along with equation 20 (fig. 43), the clear-water contraction-scour depth for the right overbank (outside the region of the abutment scour) is estimated: $y_{s}=4.6 \mathrm{ft}$. Because the estimate of scour depth in the clear-water contraction scour region exceeds that of the left clear-water abutment-scour region, and because the top width of the abutment-scour hole encompasses the entire overbank, the estimated clear-water contraction scour for the overbank will be used for the estimated scour at the left abutment (see item 3 in report section, “Assessing Clear-Water Abutment-Scour Potential”).

\section{Clear-Water Pier Scour for the Right Overbank}

Using equation 2 (fig. 7), the potential pier-scour depth for the right overbank piers, which have a width of $1.4 \mathrm{ft}$, is $2.6 \mathrm{ft}$. The total scour depth for the piers located in the clear-water overbank region, outside of the clear-water abutment-scour region, is 4.6 (previously computed clearwater contraction scour $)+2.6=7.2 \mathrm{ft}$.

\section{Live-Bed Contraction-Scour Potential}

Benedict and Caldwell (2009) indicated that their investigation did not identify a definitive method for qualitatively assessing the potential live-bed contraction scour. They noted that "...the practitioner must use caution and judgment when qualitatively assessing this type of scour" and recommended a number of steps for making the assessment. The more detailed assessment that should be done is beyond the scope of this example problem. For this example, a comparison of the live-bed contraction-scour potential using the dimensionless equation for the Piedmont (eq. 25; fig. 48B) will be made with the estimate from the field envelope curve (eq. 26; fig. 49A).

Using the dimensionless equation for the Piedmont (eq. 25; fig. 48B) with the approach depth of $23.2 \mathrm{ft}$, the potential live-bed contraction-scour depth is about $16 \mathrm{ft}$. In contrast, using the field envelope curve (eq. 26; fig. 48A), the potential live-bed contraction-scour depth is about $12 \mathrm{ft}$. (Note: The drainage area for this site is greater than $200 \mathrm{mi}^{2}$, which precludes the use of the modified live-bed contractionscour envelope curve as shown in figure 53.) Because of the higher degree of uncertainty in the live-bed contraction-scour envelope curves (Benedict and Caldwell, 2009), the more conservative estimate of $16 \mathrm{ft}$ was selected as the estimate of live-bed contraction scour for this site (fig. 65).

\section{Live-Bed Pier-Scour Potential}

Using equation 6 (fig. 10) and the channel pier width of $3 \mathrm{ft}$, the live-bed pier-scour potential is $6.7 \mathrm{ft}$. There is no skew associated with this pier and, therefore, no adjustment for pier skew is required.
The region of potential scour determined from these computations is shown in figure 65. It is important to remember that the scour estimates shown in figure 65 are based on hydraulic data determined from the 100 -year recurrence interval flow estimated for this site in conjunction with the appropriate South Carolina bridge-scour envelope curve; and although the estimated scour depths from the envelope curves reflect scour depths associated with flows near the 100-year flow, the estimates should not be interpreted as the "100-year" scour estimates. In an actual analysis, the user also should utilize the available South Carolina bridgescour databases to compare the estimated scour results with observed results from sites with similar characteristics and in similar areas of the State.

Applying the appropriate 500-year flow adjustment coefficient to the previously computed scour components results in the following (fig. 66):

\section{Clear-Water Abutment Region}

Left abutment:

Using equation 18 (fig. 41), potential clear-water abutment scour for the left abutment $=1.21 \times 4.56=5.6 \mathrm{ft}$.

Right abutment:

Using equation 18 (fig. 41), potential clear-water abutment scour for the right abutment $=1.2 \times 13=16 \mathrm{ft}$.

Clear-Water Overbank Region

Left overbank:

The left abutment top width encompasses the entire overbank, and therefore, the estimated clear-water abutment scour depth is used in this region.

Right overbank:

Using equation 21 (fig. 46), potential clear-water contraction scour $=1.46 \times 4.6=6.7 \mathrm{ft}$.

Using equation 11 (fig. 20), potential clear-water pier scour for the right overbank $=1.09 \times 2.6=2.8 \mathrm{ft}$.

Total potential scour at piers in the clear-water overbank region $=6.7+2.8=9.5 \mathrm{ft}$.

\section{Live-Bed Channel Region}

Using equation 27 (fig. 54), potential live-bed contraction scour $=1.32 \times 16=21 \mathrm{ft}$.

Using equation 11 (fig. 20), potential live-bed pier scour $=1.09 \times 6.7=7.3 \mathrm{ft}$.

Total potential scour at piers in the live-bed channel region $=21+7.3=28.3 \mathrm{ft}$.

Applying the 500-year flow adjustment coefficients provides perspective on the relative increase in theoretical clear-water abutment, contraction, and pier scour associated with the 100- to 500-year flow conditions but should not be interpreted as the "500-year" scour estimates. 


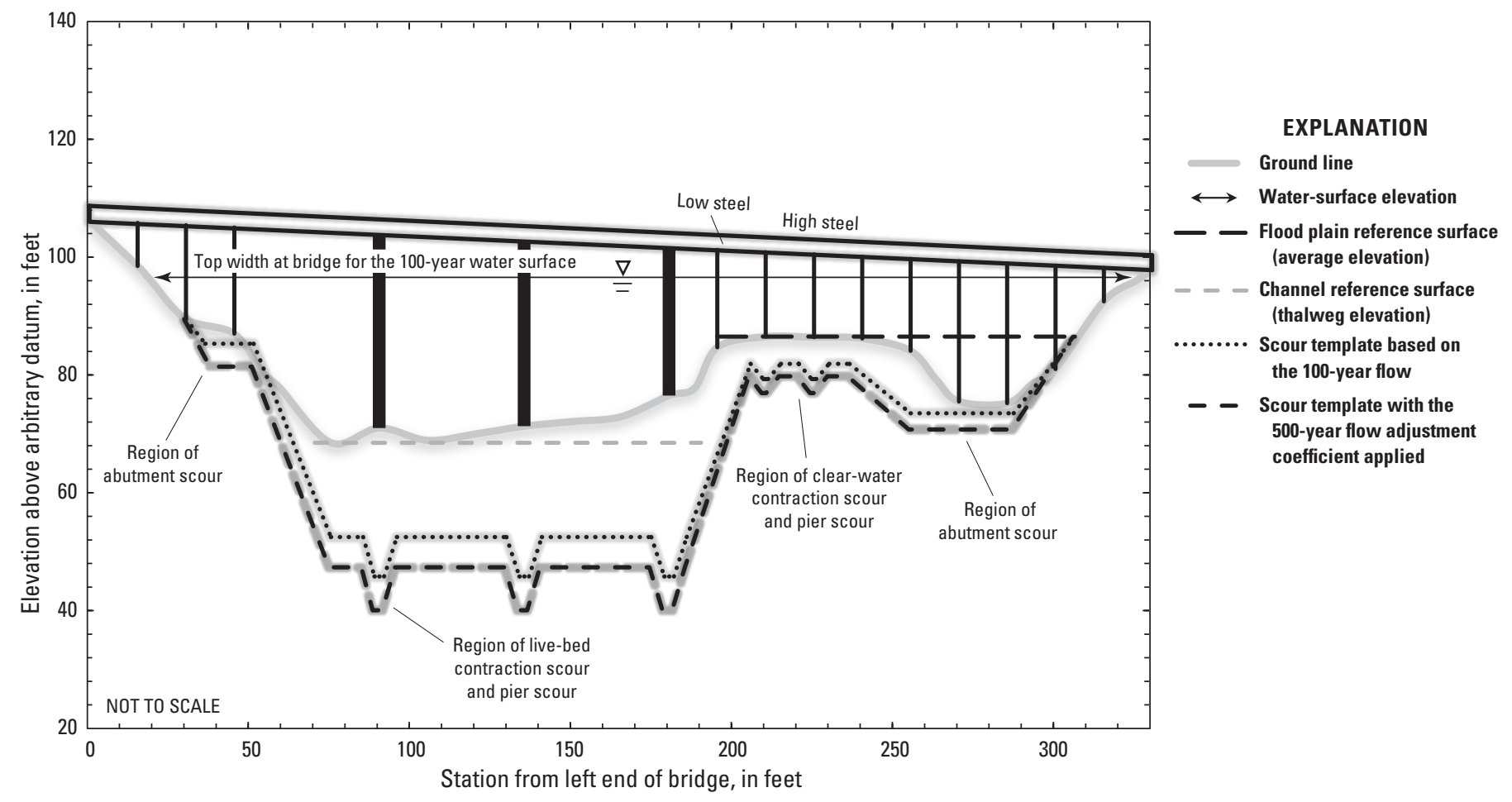

Figure 66. Region of potential scour determined from the South Carolina bridge-scour envelope curves for example 3, Enoree River at Road S-87 in Newberry County, South Carolina, with the 500-year flow adjustment coefficient applied.

\section{Summary}

Current practices for predicting scour at bridges are based on laboratory-derived equations and provide an important resource for assessing scour potential; however, there is a measure of uncertainty when applying such procedures to field conditions. One way to evaluate the reasonableness of predicted scour from the laboratory-derived equations is to compare the results with field measurements of historic scour.

The U.S. Geological Survey has been partnering with the South Carolina Department of Transportation for more than two decades to improve the understanding of bridge scour and enhance methods for assessing potential bridge scour in South Carolina. As a part of this effort, the U.S. Geological Survey previously conducted a series of three field investigations to collect and analyze historic scour measurements in order to better understand regional trends of scour in South Carolina. As part of those studies, historic scour data were collected at 231 riverine bridges and included measurements of clear-water abutment-scour, contraction-scour, and pier-scour depths, as well as live-bed contraction- and pier-scour depths. From those investigations, regional bridge-scour envelope curves were developed for the various scour components, providing supplementary tools for assessing those components of scour at riverine bridges in South Carolina.

On the basis of the previous scour investigations, this report provides a guidance manual for an integrated approach for using the envelope curves for the various scour components to help assess scour potential at riverine bridges in South Carolina. Limited verification of selected envelope curves was made by comparing the data with previously published field data from sources outside of South Carolina, including the U.S. Geological Survey National Bridge Scour Database, the U.S. Geological Survey 2014 Pier Scour Database, and selected field measurements of scour from other States. In general, the comparisons showed similar trends in the South Carolina data and indicated that the South Carolina envelope curves were reasonable.

The South Carolina bridge-scour envelope curves were developed from field data having historic flows approaching the 100-year flow magnitude and, therefore, are considered appropriate for assessing scour potential for flows near the 100-year flow but are not recommended for assessing scour potential for extreme flows such as the 500-year flow. In order to extend the application of the envelope curves to flow conditions near the 500-year flow, a correlation analysis was done using theoretical scour computations from previous level-2 scour computations that were based on hydraulic information for the 100- and 500-year flows. From the analyses of the various scour components, theoretical 500-year flow adjustment coefficients were developed. The adjustment coefficients are a useful tool for gaining perspective on the relative increase of theoretical scour associated with the 100- to 500-year flows but should not be considered as a definitive estimate of the scour associated with the 500-year flow. 
The bridge-scour envelope curve guidance manual provides information on the application and limitations of the various bridge-scour envelope curves developed using field data from South Carolina. In addition, guidance for applying the South Carolina bridge-scour envelope curves also is provided. The South Carolina bridge-scour envelope curves are useful tools for assessing potential for scour at riverine bridges in South Carolina; however, the envelope curves are empirical methods with limitations and, therefore, should not be relied upon as the only tool for assessing bridge scour but should be used in conjunction with the prevailing scourprediction technology (currently HEC-18). To best assess potential scour, one should compile and study the available information for a given site, evaluate scour with the South Carolina bridge-scour envelope curves and the prevailing scour-prediction technology (currently HEC-18), and then bring sound engineering principles to bear on the final estimate of potential scour at a given site.

\section{Acknowledgments}

The authors acknowledge and appreciate the longstanding partnership between the USGS South Atlantic Water Science Center (formerly the South Carolina Water Science Center), and the South Carolina Department of Transportation. The two agencies have cooperated on numerous bridge-scour investigations for more than two decades. These investigations have resulted in improved understanding of bridge-scour processes and development of supplementary tools for the assessment of bridge-scour potential based on measured data at bridge crossings of streams throughout South Carolina.

\section{Selected References}

Ansari, S.A., and Qadar, A., 1994, Ultimate depth of scour around bridge piers, in The 1994 National Conference on Hydraulic Engineering, Buffalo, N.Y., 1994, Proceedings: Reston, Va., American Society of Civil Engineers, p. 51-55.

Arneson, L.A., and Shearman, J.O., 1998, User's manual for WSPRO-A computer model for water surface profile computations: Federal Highway Administration, Publication No. FHWA-SA-98-080, 323 p.

Arneson, L.A., Zevenbergen, L.W., Lagasse, P.F., and Clopper, P.E., 2012, Evaluating scour at bridges (5th ed.): Federal Highway Administration Hydraulic Engineering Circular No. 18, Publication No. FHWA-HIF-12-003, $340 \mathrm{p}$.

Ballio, Francesco, Teruzzi, A., and Radice, A., 2009, Constriction effects in clear-water scour at abutments: Journal of Hydraulic Engineering, v. 135, no. 2, p. 140-145.
Basak, V., Baslamisli, Y., and Ergun, O., 1977, Local scour depths around circular pier groups aligned with the flow: Turkey General Directorate of State Hydraulic Works Report No. 641. [In Turkish.]

Bedient, P.B., and Huber, W.C., 1988, Hydrology and flood plain analysis: Reading, Mass., Addison-Wesley Publishing Co., $650 \mathrm{p}$.

Benedict, S.T., 2003, Clear-water abutment and contraction scour in the Coastal Plain and Piedmont Provinces of South Carolina, 1996-99: U.S. Geological Survey WaterResources Investigations Report 03-4064, 137 p.

Benedict, S.T., 2016, The upper bound of abutment scour in laboratory and field data, Transportation Research Record: Journal of the Transportation Research Board, No. 2588, Transportation Research Board, Washington, D.C., 2016, p. 154-162. DOI: $10.3141 / 2588-17$

Benedict, S.T., Abrahamsen, T.A., and Caldwell, A.W., 2007, Collection of historical live-bed scour data at selected bridges in South Carolina using ground-penetrating radar, in The World Environmental and Water Resources Congress, Tampa, Fla., 2007, Proceedings: Reston, Va., American Society of Civil Engineers, p. 1-11.

Benedict, S.T., and Caldwell, A.W., 2006, Development and evaluation of clear-water pier and contraction scour envelope curves in the Coastal Plain and Piedmont Provinces of South Carolina: U.S. Geological Survey Scientific Investigations Report 2005-5289, 98 p.

Benedict, S.T., and Caldwell, A.W., 2009, Development and evaluation of live-bed pier and contraction scour envelope curves in the Coastal Plain and Piedmont Provinces of South Carolina: U.S. Geological Survey Scientific Investigations Report 2009-5099, 108 p.

Benedict, S.T., and Caldwell, A.W., 2012, Modification of selected South Carolina bridge-scour envelope curves: U.S. Geological Survey Scientific Investigations Report 2012-5029, 37 p.

Benedict, S.T., and Caldwell, A.W., 2014, A pier-scour database - 2,427 field and laboratory measurements of pier scour: U.S. Geological Survey Data Series 845, 22 p., accessed July 29, 2016, at http://dx.doi.org/10.3133/ds845.

Benedict, S.T., and Caldwell, A.W., 2015, The upper bound of pier scour defined by selected laboratory and field data, in SEDHYD 2015, Reno, Nev., 2015, Proceedings, accessed July 29, 2016, at http://www.sedhyd.org/2015/openconf/ modules/request.php?module $=$ oc_program\&action $=$ summary.php\&id $=158$.

Benedict, S.T., and Caldwell, A.W., 2016, The upper bound of pier scour in laboratory and field data, Transportation Research Record: Journal of the Transportation Research Board, No. 2588, Transportation Research Board, Washington, DC, 2016, p. 145-153, http://dx.doi.org/10.3141/2588-16. 
Bloxham, W.M., 1976, Low-flow characteristics of streams in the Inner Coastal Plain of South Carolina: South Carolina Water Resources Commission Report No. 5, 41 p.

Bohman, L.R., 1990, Determination of flood hydrographs for streams in South Carolina-Volume 1. Simulation of flood hydrographs for rural watersheds in South Carolina: U.S. Geological Survey Water-Resources Investigations Report 89-4087, 53 p.

Bohman, L.R., 1992, Determination of flood hydrographs for streams in South Carolina-Volume 2. Estimation of peakdischarge frequency, runoff volumes, and flood hydrographs for urban watersheds: U.S. Geological Survey WaterResources Investigations Report 92-4040, 79 p.

Bradley, J.B., Richards, D.L., and Bahner, C.D., 2005, Debris control structures - Evaluation and countermeasures: Federal Highway Administration Hydraulic Engineering Circular No. 9, Publication No. FHWA-IF-04-016, 179 p.

Breusers, H.N.C., 1965, Scouring around drilling platforms: International Association of Hydraulic Engineering and Research, Hydraulic Research 1964/65, Bulletin 19, 276 p.

Breusers, H.N.C., Nicollet, G., and Shen, H.W., 1977, Local scour around cylindrical piers: Journal of Hydraulic Research, v. 15, no. 3, p. 211-252.

Breusers, H.N.C., and Raudkivi, A.J., 1991, Scouring: Rotterdam, A.A. Balkema, 143 p.

Briaud, J.-L., Chen, H.-C., Chang, K.-A., Oh, S.J., and Chen, X., 2009, Abutment scour in cohesive material: Washington, D.C., Transportation Research Board of the National Academies, National Research Council, NCHRP Report 24-15(2).

Brunner, G.W., 2016, HEC-RAS: River analysis system user's manual, version 5.0: U.S. Army Corps of Engineers, Hydrologic Engineering Center, Report No. CPD-68, 962 p.

Chabert, J., and Engeldinger, P., 1956, Etude des affouillements autour des piles des ponts: Chatou, France, Laboratoire d'Hydraulique.

Chang, F., and Davis S.R., 1999, Maryland SHA procedure for estimating scour at bridge abutments, Part 2-Clear water scour, in Richardson, E.V., and Lagasse, P.F., eds., Stream stability and scour at highway bridges, Compendium of papers, ASCE Water Resources Engineering Conferences, 1991 to 1998: Reston, Va., American Society of Civil Engineers, p. 412-416.

Das, B.P., 1973, Bed scour at end-dump channel constrictions: Journal of the Hydraulics Division, American Society of Civil Engineers, v. 99, no. 12, p. 2273-2291.

Dongol, D.M.S., 1993, Local scour at bridge abutments: New Zealand, University of Auckland, School of Engineering Report No. 544, 410 p.
Ettema, R., Constantinescu, G., and Melville, B., 2011, Evaluation of bridge scour research-Pier scour processes and predictions: Transportation Research Board of the National Academies, National Cooperative Highway Research Program Web Document 175 (Project 24-27(01)), 195 p., accessed July 21, 2011, at http://onlinepubs.trb.org/onlinepubs/nchrp/nchrp_w175.pdf.

Ettema, Robert, Melville, B.W., and Barkdoll, Brian, 1998, Scale effect in pier-scour experiments: Journal of Hydraulic Engineering, v. 124, no. 6, p. 639-642.

Ettema, R., Nakato, T., and Muste, N., 2010, Estimation of scour depth at bridge abutments: Transportation Research Board of the National Academies, National Cooperative Highway Research Program, Draft final report, NCHRP Report 24-20, (Project 24-20), 436 p.

Feaster, T.D., and Tasker, G.D., 2002, Techniques for estimating the magnitude and frequency of floods in rural basins of South Carolina, 1999: U.S. Geological Survey WaterResources Investigation Report 02-4140, 34 p.

Froehlich, D.C., 1989, Local scour at bridge abutments: Proceedings of the 1989 National Conference on Hydraulic Engineering: New York, American Society of Civil Engineering, p. 13-18.

Gao, D., Posada, G.L., and Nordin, C.F., 1993, Pier scour equations used in the People's Republic of China: Washington, D.C., Federal Highway Administration report FHWA-SA-93-076.

Gill, M.A., 1981, Bed erosion in rectangular long contraction: Journal of the Hydraulics Division, American Society of Civil Engineers, v. 107, no. 3, p. 273-284.

Guimaraes, W.B., and Bohman, L.R., 1992, Techniques for estimating magnitude and frequency of floods in South Carolina, 1988: U.S. Geological Survey Water-Resources Investigations Report 91-4157, 174 p.

Gunter, H.C., Mason, R.R., and Stamey, T.C., 1987, Magnitude and frequency of floods in rural and urban basins of North Carolina: U.S. Geological Survey Water-Resources Investigations Report 87-4096, 52 p.

Hancu, S., 1971, Sur le calcul des affouillements locaux dans la zone des piles de ponts, in Proceedings of the 14th International Association for Hydraulic Research Congress, v. 3, p. 299-313. (In French.)

Hayes, D.C., 1996, Scour at bridges in Delaware, Maryland, and Virginia: U.S. Geological Survey Water-Resources Investigations Report 96-4089, 35 p.

Holmes, R.R., and K. Dinicola, 2010, 100-year flood-It's all about chance: U.S. Geological Survey General Information Product 106, 4 p. 
Huizinga, R.J., and Rydlund, P.H., Jr., 2004, Potential-scour assessments and estimates of scour depth using different techniques at selected bridge sites in Missouri: U.S. Geological Survey Scientific Investigations Report 2004-5213, $42 \mathrm{p}$.

Hurley, N.M., Jr., 1996, Assessment of scour-critical data collected at selected bridges and culverts in South Carolina, 1990-92: U.S. Geological Survey Open-File Report 96-350, $119 \mathrm{p}$.

Jain, S.C., and Fischer, E.E., 1979, Scour around circular bridge piers at high Froude numbers: Federal Highway Administration Report No. FHWA-RD-79-104, 67 p.

Landers, M.N., and Mueller, D.S., 1993, Reference surfaces for bridge scour depths, in The 1993 National Conference on Hydraulic Engineering, San Francisco, Calif., 1993, Proceedings: Reston, Va., American Society of Civil Engineers, v. 2, p. 2075-2080.

Larras, J., 1963, Profondeurs maximales d'erosion des fonds mobiles autour des piles en riviere: Ann. Ponts et Chaussees, v. 133, no. 4, p. 411-424.

Laursen, E.M., 1960, Scour at bridge crossings: Journal of the Hydraulics Division, American Society of Civil Engineers, v. 89 , no. 3 .

Laursen, E.M., 1963, An analysis of relief bridge scour: Journal of the Hydraulics Division, American Society of Civil Engineers, v. 92, no. 3.

Laursen, E.M., and Toch, A., 1956, Scour around bridge piers and abutments: Iowa Highway Research Board, Bulletin No. 4, 60 p.

Lee, K.G., and Hedgecock, T.S., 2008, Clear-water contraction scour at selected bridge sites in the Black Prairie Belt of the Coastal Plain in Alabama, 2006: U.S. Geological Survey Scientific Investigations Report 2007-5260, 56 p.

Lombard, P.J., and Hodgkins, G.A., 2008, Comparison of observed and predicted abutment scour at selected bridges in Maine: U.S. Geological Survey Scientific Investigations Report 2008-5099, 23 p.

MALA GeoScience, RAMAC GroundVision, Software Manual, version 1.3, 37 p.

Melville, B.W., 1992, Local scour at bridge abutments: Journal of Hydraulic Engineering, American Society of Civil Engineering, v. 118, no. 4, p. 615-630.

Melville, B.W., 1984, Live-bed scour at bridge piers: Journal of Hydraulic Engineering, American Society of Civil Engineering, v. 110, no. 9, p. 1234-1247.

Melville, B.W., and Coleman, S.E., 2000, Bridge scour: Highlands, Colo., Water Resources Publications, 550 p.
Mueller, D.S., 1996, Local scour at bridge piers in nonuniform sediment under dynamic conditions: Fort Collins, Colorado State University, Civil Engineering Department, Ph.D. dissertation, $212 \mathrm{p}$.

Mueller, D.S., and Wagner, C.R., 2005, Field observations and evaluations of streambed scour at bridges: Federal Highway Administration, Publication FHWA-RD-03-052, 122 p.

National Cooperative Highway Research Program, 1970, Scour at bridge waterways: Washington, D.C., Highway Research Board, National Academy of Sciences, 37 p.

Neill, C.R., 1964, Local scour around bridge piers-A comparative analysis of model experiments and field data: Highway and River Engineering Division, Research Council of Alberta, $48 \mathrm{p}$.

Neill, C.R., ed., 1973, Guide to bridge hydraulics: Toronto, Ontario, Roads and Transportation Association of Canada, University of Toronto Press, $191 \mathrm{p}$.

Norman, V.W., 1975, Scour at selected bridge sites in Alaska: U.S. Geological Survey Water-Resources Investigations Report 32-75, 160 p.

Palaviccini, M., 1993, Predictor model for bridge abutments: Washington, D.C., The Catholic University of America, Ph.D. thesis.

Parola, A.C., Hagerty, D.J., and Kamojjala, S., 1998, Highway infrastructure damage caused by the 1993 Upper Mississippi River Basin flooding: National Cooperative Highway Research Program, Transportation Research Board of the National Academies, NCHRP Report 417, 172 p.

Placzek, Gary, and Haeni, F.P., 1995, Surface-geophysical techniques used to detect existing and infilled scour holes near bridge piers: U.S. Geological Survey Water-Resources Investigations Report 95-4009, 44 p.

Pope, B.F., Tasker, G.D., and Robbins, J.C., 2001, Estimating magnitude and frequency of floods in rural basins of North Carolina (revised): U.S. Geological Survey WaterResources Investigations Report 01-4207, 44 p.

Richardson, E.V., and Davis, S.R., 2001, Evaluating scour at bridges (4th ed.): Federal Highway Administration Hydraulic Engineering Circular No. 18, Publication No. FHWA NHI 01-001, 378 p.

Richardson, E.V., Harrison, L.J, and Davis, S.R., 1991, Evaluating scour at bridges: Federal Highway Administration Hydraulic Engineering Circular No. 18, Publication No. FHWA-IP-90-017, 105 p.

Richardson, E.V., Harrison, L.J., Richardson, J.R., and Davis, S.R., 1993, Evaluating scour at bridges (2d ed.): Federal Highway Administration Hydraulic Engineering Circular No. 18, Publication No. FHWA-IP-90-017, 131 p. 
Richardson, E.V., Simons, D.B., and Lagasse, P.F., 2001, River engineering for highway encroachments: Federal Highway Administration Hydraulic Design Series Number 6, Publication No. FHWA NHI 01-004, 644 p.

Ries, K.G., III, Guthrie, J.D.,, Rea A.H., Steeves, P.A., and Stewart, D.W., 2008, StreamStats-A water resources Web application: U.S. Geological Survey Fact Sheet 2008-3067, 6 p., accessed July 29, 2016, at http://pubs.usgs.gov/ fs $/ 2008 / 3067 /$.

Shearman, J.O., 1990, User's manual for WSPRO—A computer model for water-surface profile computations: Federal Highway Administration, Report No. FHWAIP-89-027, 175 p.

Shen, H.W., Schneider, V.R., and Karaki, S., 1966, Mechanics of local scour, data supplement. Colorado State University CER 66-67 HWS-VRS-SK-27, prepared for U.S. Department of Commerce, Bureau of Public Roads, Office of Research and Development, Structures and Applied Mechanics Division under Contract No. CPR 11-8022.

Sheppard, D.M., Demir, Huseyin, and Melville, Bruce, 2011, Scour at wide piers and long skewed piers: Washington, D.C., Transportation Research Board of the National Academies, NCHRP Report 682, 65 p.

Southard, S.E., 1992, Scour around bridge piers on stream banks in Arkansas: U.S. Geological Survey WaterResources Investigations Report 92-4126, 29 p.

Sturm, T.W., 2004, Enhanced abutment scour studies for compound channels: McLean, Va., Federal Highway Administration, Report No. FHWA-RD-99-156.

Sturm, T.W., Ettema, R., and, Melville, B.W., 2011, Evaluation of bridge-scour research-Abutment and contraction scour processes and prediction: Washington, D.C., Transportation Research Board of the National Academies, National Cooperative Highway Research Program Web-Only Document 181.

Tarapore, Z.S., 1962, A theoretical and experimental determination of the erosion patterns caused by obstructions in an alluvial channel with particular reference to a vertical cylindrical pier: Minneapolis, University of Minnesota, Ph.D. thesis.
U.S. Geological Survey, 2001, National Bridge Scour Database, accessed October 15, 2008, at http://water.usgs.gov/ osw/techniques/bs/BSDMS/index.htm.

Wagner, C.R., Mueller, D.S., Parola, A.C., Hagerty, D.J., and Benedict, S.T., 2006, Scour at contracted bridges: Transportation Research Board of the National Academies, National Cooperative Highway Research Program Document 83 (Project 2414), 299 p., accessed December 19, 2008, at http://onlinepubs.trb.org/onlinepubs/nchrp/nchrp_w83.pdf.

Webb, D.J., Anderson, N.L., Newton, Tim, and Cardimona, Steve, 2000, Bridge scour - Application of ground penetrating radar: Federal Highway Administration and Missouri Department of Transportation Special Publication, accessed December 6, 2006, at http://campus.umr.edu/utc/pubs/ conf/2000/scour.pdf.

White, W.R., 1975, Scour around bridge piers in steep streams, in Proceedings of the 16th IAHR Congress, Sao Paulo, Brazil, v. 2, p. 279-284.

Yang, T.Y., 1996, Sediment transport theory and practice: New York, McGraw-Hill, 396 p.

Yanmaz, A.M., and Cicekdag, Ozgur, 2001, Composite reliability model for local scour around cylindrical bridge piers: Canadian Journal of Civil Engineering, v. 28, no. 3, p. 520-535.

Zalants, M.G., 1990, Low-flow characteristics of natural streams in the Blue Ridge, Piedmont, and upper Coastal Plain physiographic provinces of South Carolina: U.S. Geological Survey Water-Resources Investigations Report 90-4188, $92 \mathrm{p}$.

Zalants, M.G., 1991, Low-flow frequency and flow duration of selected South Carolina streams through 1987: U.S. Geological Survey Water-Resources Investigations Report 91-4170, $87 \mathrm{p}$.

Zhuravlyov, M.M., 1978, New method for estimation of local scour due to bridge piers and its substantiation: Transactions, Ministry of Transport Construction, State All Union Scientific Research Institute on Roads, Moscow, Russia. 
Manuscript approved August 17, 2016

Prepared by the USGS Science Publishing Network Reston Publishing Service Center

Edited by Kay P. Naugle

Illustrations by Jeffrey Corbett

Layout by Caryl J. Wipperfurth

For more information concerning this report, please contact:

Director

South Atlantic Water Science Center

U.S. Geological Survey

720 Gracern Road

Columbia, SC 29210

http://www.usgs.gov/water/southatlantic/ 


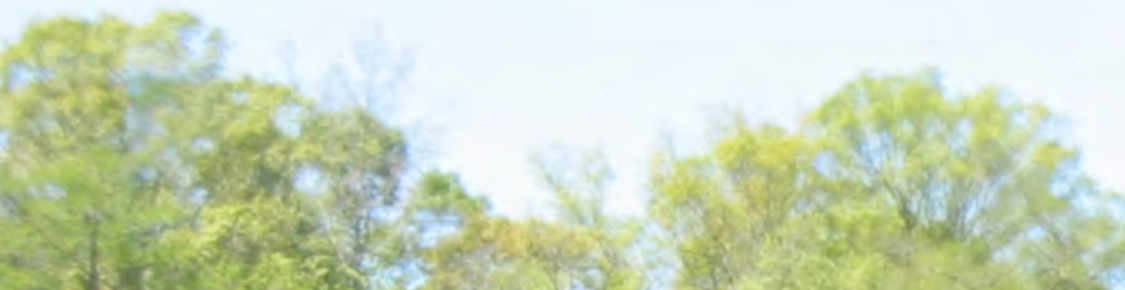

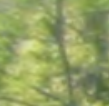

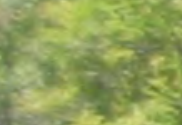

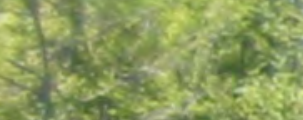

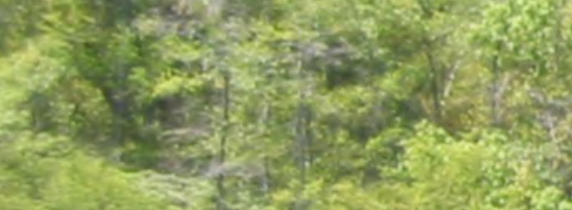

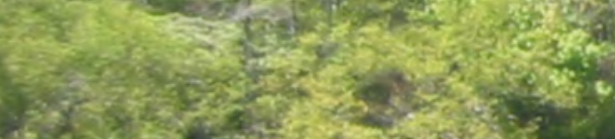

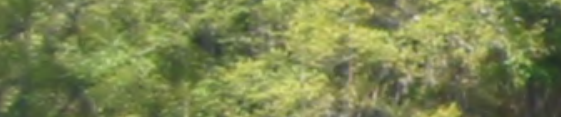

(6)

(2.)

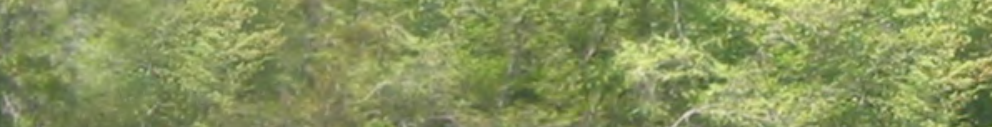

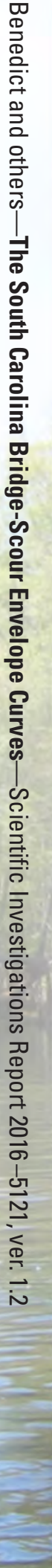

(1)

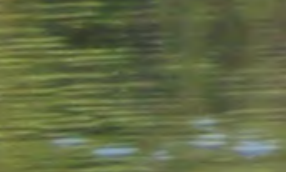

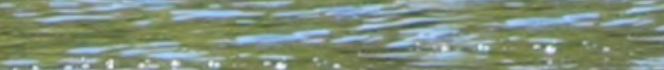
(5)

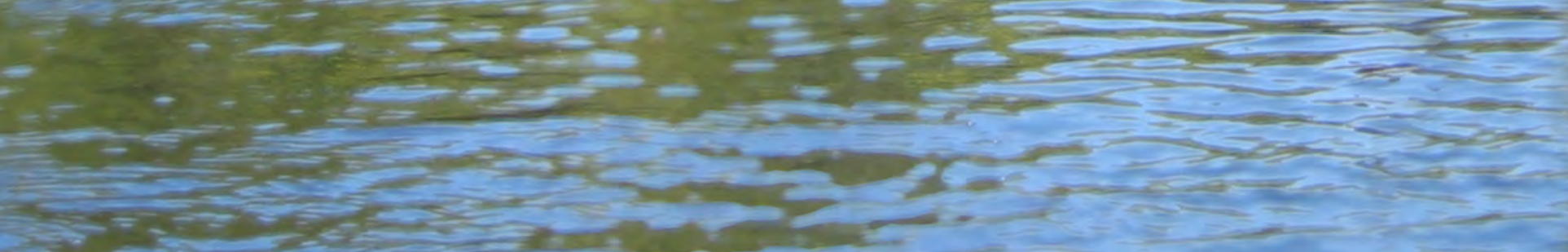

